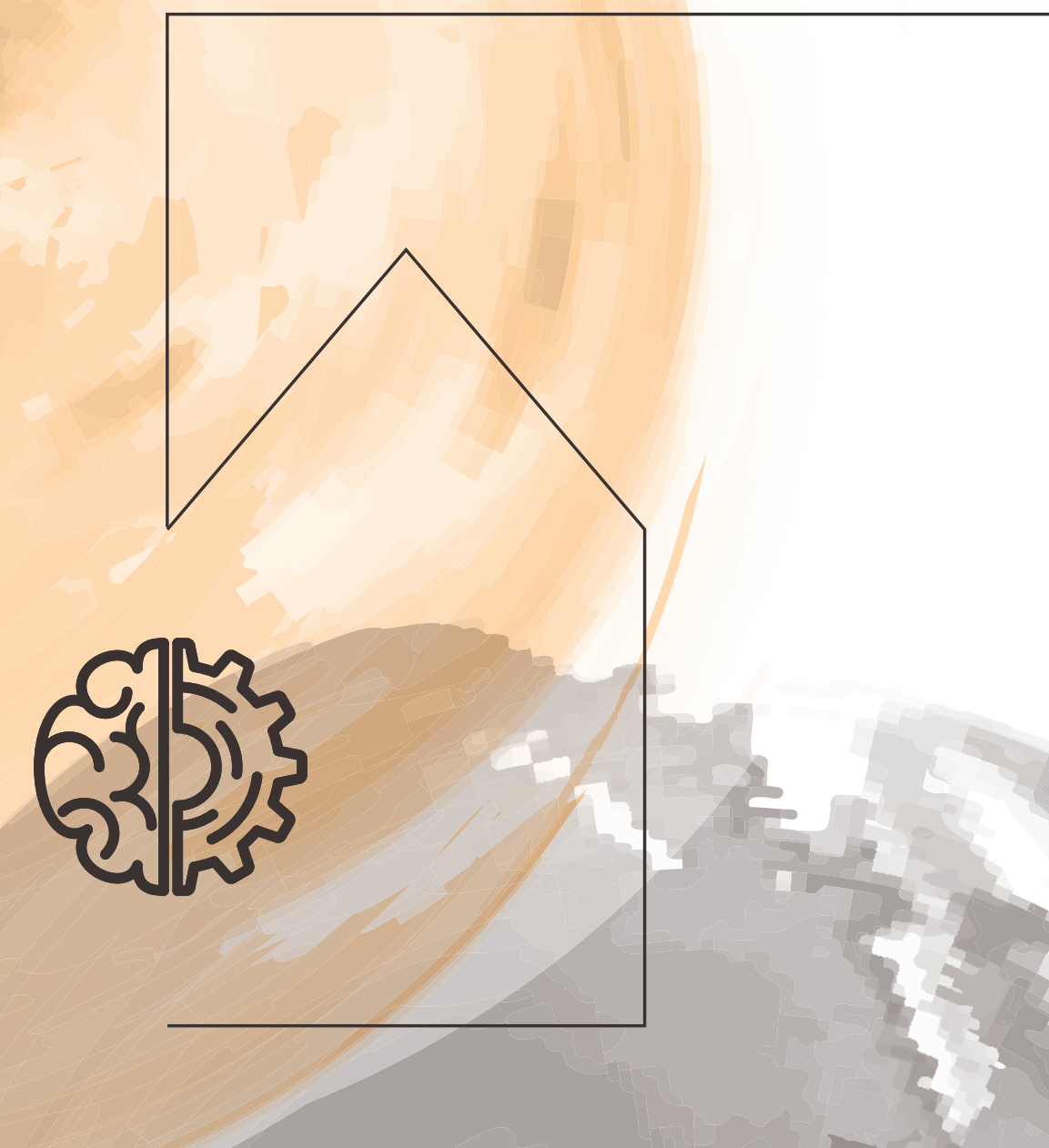

ON THE ADOPTION OF INNOVATION IN THE HOUSING SECTOR

J.A.W.H. van Oorschot 



\section{ON THE ADOPTION OF INNOVATION IN THE HOUSING SECTOR}

John van Oorschot 


\title{
ON THE ADOPTION OF INNOVATION IN THE HOUSING SECTOR
}

\author{
DISSERTATION \\ to obtain \\ the degree of doctor at the University of Twente, \\ on the authority of the rector magnificus, \\ prof. dr. T.T.M. Palstra, \\ on account of the decision of the Doctorate Board, \\ to be publicly defended
}

on Wednesday the $25^{\text {th }}$ of November 2020 at 14.45 hours

by

Johannes Antonius Wilhelmus Hubertus van Oorschot

born on the 30th of March 1982

in Eindhoven, the Netherlands 
This dissertation has been approved by:

Promoter: prof.dr.ir. J.I.M. Halman

Co-promoter: dr.ir. E. Hofman

This research was funded by Stichting Pioneering - $\underline{\text { http://www.pioneering.nl/ }}$

Cover design: Yvonne van Oorschot-Spiero

Cover picture: betelgejze from 123rf.com

Printed by: Ipskamp Printing

Layout: Yvonne van Oorschot-Spiero

ISBN: 978-90-365-5091-8

DOI: $10.3990 / 1.9789036550918$

(C) 2020. If one refers to the author, title and year of publication, every part of this thesis may be used for non-commercial purposes, free of charge and free of copyrights without the written permission from the author. For commercial purposes written permission from the author is required. 


\section{GRADUATION COMMITTEE}

$\begin{array}{lll}\begin{array}{l}\text { Chairman/ } \\ \text { Secretary }\end{array} & \text { Prof.dr.ir. H.F.J.M. Koopman } & \text { University of Twente } \\ & & \text { Engineering Technology } \\ \text { Promoter } & \text { Prof.dr.ir. J.I.M. Halman } & \text { University of Twente } \\ & & \text { Engineering Technology } \\ \text { Co-promoter } & \text { Dr.ir. E. Hofman } & \\ & & \text { University of Twente }\end{array}$

Member Prof.dr.ir. P.C. de Weerd-Nederhof University of Twente

Behavioural, Management and Social Sciences

Dr. J.T. Voordijk

Prof.dr.ir. J.J.N. Lichtenberg

Prof.dr.ir. H.J. Visscher

Prof.dr. ir. B.A.G. Bossink
University of Twente

Engineering Technology

Eindhoven University of Technology

Built Environment

Technical University Delft

Architecture and the Built Environment

VU University Amsterdam

Science, Business E Innovation 



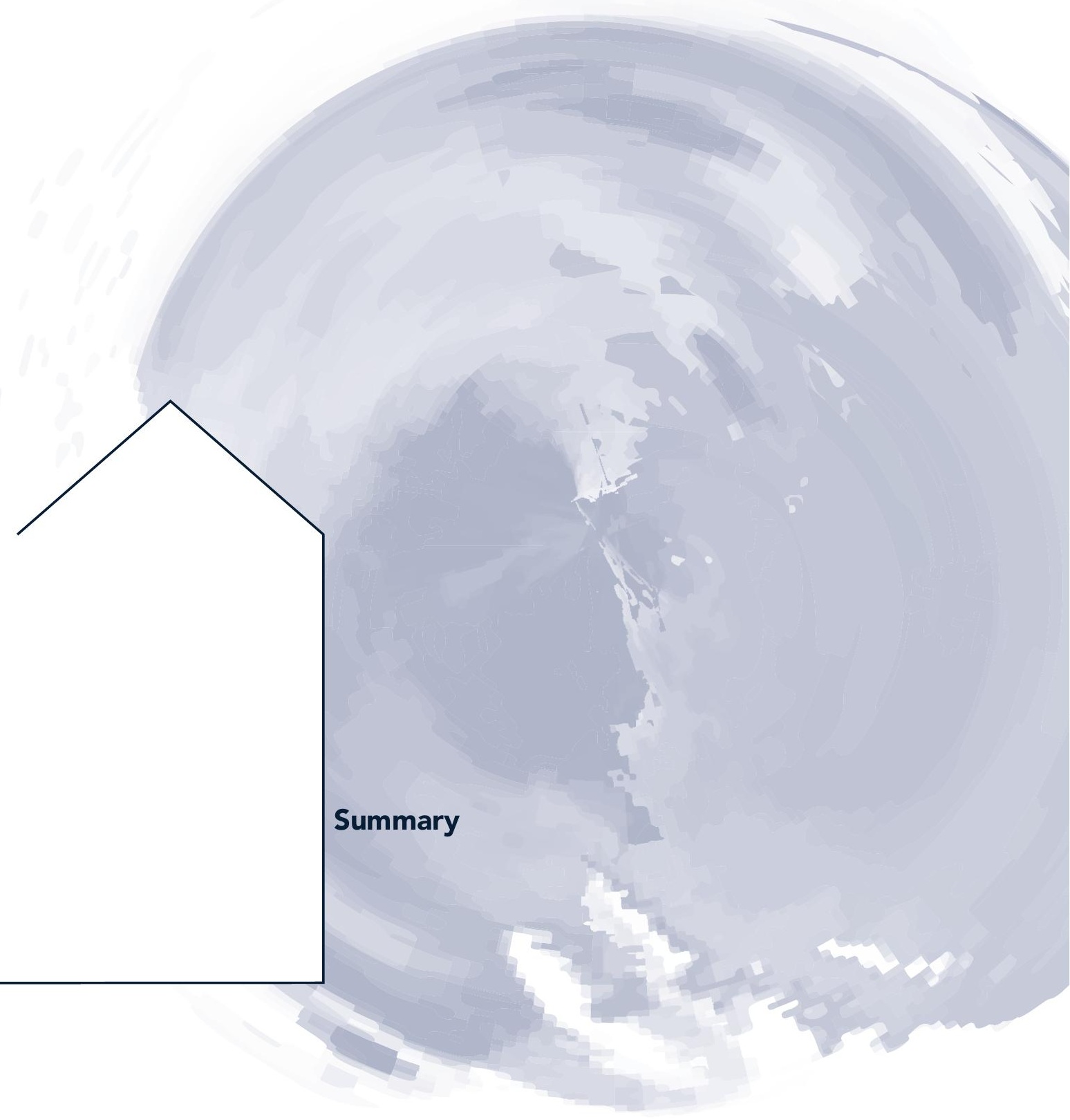




\section{Summary}

Background - Industrialization, digitalization and innovation in housing are essential if one is to address problems such as an increasing demand for affordable housing, labour shortages, the sector's significant environmental impact and fast-changing market needs. This requires substantial innovations ranging from new building materials and components to completely new housing systems. Ideally, these innovations will not only contribute to shorter building times, lower failure costs, a higher build quality, but also result in more sustainable and circular building concepts. However, to benefit from such innovations, they have to be adopted on a large scale.

Knowledge gap - The adoption of a housing innovation can be defined as the decision to apply a product, process or system innovation in a housing project. Despite efforts to develop and introduce innovation in housing, the market has proved reluctant to adopt many of these innovations on a significant scale. When innovations have been successfully applied, they tend to be adopted only on a small scale, and fail to diffuse in the market beyond the initial demonstration status. As a result, the industry appears severely locked in to traditional construction practices. This is problematic since housing projects continue to be plagued by cost and time overruns, low productivity and inefficiency, housing quality issues and a high environmental impact.

The Dutch Science, Technology and Innovation Council (Adviesraad voor Wetenschap, Technologie en Innovation), an advisory council of the government, stated that the adoption and diffusion of innovations had not been sufficiently addressed by researchers and policymakers in the Dutch economy. In this respect, the Dutch construction sector was explicitly mentioned by the advisory council. A more in-depth understanding of the adoption of an innovation within a specific housing project, and subsequently in other housing projects, could have a substantial impact on the adoption rate of innovations in the housing sector. Previous research has observed that it is difficult to get innovations adopted on a wide scale in the housing sector, and that general innovation adoption theories insufficiently explain the poor uptake of innovation in this sector. In this respect, it has been hypothesised that innovation cannot be understood beyond the context of its development, adoption and subsequent diffusion. That is, if one wants to understand the adoption of an innovation by stakeholders involved in housing projects, the structural characteristics of the housing sector must be taken into account. What is particularly missing is context-specific empirical data on the mechanisms that affect the adoption of various types of innovation, and across different levels of adoption (individual, firm, project and/or sector), during the successive stages of diffusion from market formation towards saturation.

Aim of this research - The research reported in this thesis aims to enhance current understanding of the adoption of innovations in the housing sector. The emphasis is on the determinants and mechanisms that affect the decisions of construction stakeholders regarding the adoption of innovations in housing projects. The associated finding can deepen the limited understanding of the variables and mechanisms that affect the adoption of various types of innovation at different points in time. These insights can help managers and innovators to improve the adoption potential of their technological innovations across multiple projects. 
The central aim of this dissertation can be summarized in the following main research question:

"Which variables and mechanisms affect the adoption of innovation in the housing sector?"

Four studies, referred to as Studies I, II, III and $\mathrm{IV}$, were conducted to answer this main research question.

\section{Study I: A bibliometric review of innovation adoption}

Study I includes a bibliometric review of the scientific literature on innovation adoption. In this initial study, two sub-questions are addressed:

\section{a) What are the key theoretical cornerstones of innovation adoption research? \\ b) What are the current research trends within the field of innovation adoption?}

Bibliographic mapping techniques were used to organize a large number of scientific journal papers (involving 1260 scientific articles). This resulted in the recognition that adoption research builds upon four theoretical cornerstones: a) Institutional Theory and the legitimization of innovative behaviour; b) Theory of Reasoned Action and the Technology Acceptance Model; c) The determinants of innovation adoption through an econometric perspective; and d) Diffusion Theory. Further, the bibliometric review revealed five dominant research trends: 1) drivers and impediments of information technology adoption; 2) the adoption of technology standards; 3 ) organizational rationales associated with innovation adoption; 4) modelling the diffusion process; and 5) adoption of agricultural innovations. Study I complements existing reviews on innovation adoption in various ways. First, based on a co-citation analysis, it was possible to illustrate that innovation adoption research is built on four theoretical cornerstones (or, in terms of bibliographic clus- tering, on four clusters of prior publications). Second, bibliographic coupling was used to assess the current research trends in the innovation adoption literature. This review is the first to exhaustively identify thematic areas. The bibliographic coupling technique revealed five clusters of thematic publications or "research trends". Third, a coherent framework was constructed to assess the relevance of innovation adoption research by integrating the theoretical cornerstones and the current research trends. As a parallel contribution, this study found that previously conducted overview studies had contributed to a coherent understanding of innovation adoption in specific research fields. Fourth, as a key output, Study I raised several future research orientations.

\section{Study II: a literature review on innovation adoption in the housing sector}

In contrast to the first study, Study II involves a narrative, systematic literature review. Study II provides an answer to the following research question:

Given previous research on the adoption of innovation in the housing sector, which specific variables affect the adoption of innovation in the context of housing projects?

A systematic narrative review was conducted to develop a theoretical framework that could be used to assess adoption mechanisms that are specific to innovations in the housing sector. The conceptual framework includes four categories of innovation adoption determinants with their underlying variables.

The four categories are:

1. The influence of the external environment;

2. A product's characteristics and innovation attributes;

3. Industry characteristics;

4. Adopter characteristics. 
These four categories of adoption determinants include 21 underlying variables that led to the development of 21 corresponding propositions. A secondary outcome of this study is a taxonomy of technological housing innovations that characterizes the innovations adopted in housing projects. Based on this taxonomy, it was concluded that while incremental, modular and systemic innovations could be identified, radical innovations could not be found.

\section{Study III: the adoption of modular innovati- ons in housing projects}

Modular innovation is generally considered a promising strategy to progress towards circular and mass-customized housebuilding practices. Despite the potential advantages of modularity in housebuilding, the housing industry has not widely adopted modularity. Further, there is also little empirical research available on the potential adoption of modular innovations in the housing sector. Given this gap in the literature, Study III addresses the following sub-questions:

\section{a) Which mechanisms affect the adoption of modular innovation when introduced in the housing sector? \\ b) To what extent can the theory on modularity help to explain the adoption of modular inno- vation in the housing sector?}

The multiple-case study conducted in Study III aimed to reveal the determining mechanis$\mathrm{ms}$ and variables that influence the adoption of modular innovations in the Dutch housing sector.

In this study, the adoption of three modular innovations (i.e. a modular renewable energy system, a modular prefabricated bathroom pod and an integrated photovoltaic modular roof) were analysed. In addition to an extensive literature review on modularity and the study of several relevant company documents, in-depth interviews with stakeholders and the input from focus groups helped to identify mechanisms that affect the adoption of these three modular innovations.

The multiple-case study revealed 10 variables that affect the adoption of modular innovations in housing projects. After analysing the possible relationships between these 10 variables for each of the three case studies, four causal mechanisms could be deduced that determine the potential adoption of these modular innovations in housing projects. Finally, Study III also showed that, for the successful adoption of a modular innovative product, the product design must be well aligned with the supply chain and must also fit within the intended realization process for the house as a whole.

\section{Study IV: the continued adoption of building systems in housing projects}

Study II had shown that a large number of scientific publications have been published concerning the adoption of innovations in housing construction. Unfortunately, these innovations are often only applied on a small scale and often fail to spread beyond their demonstration status in the market. The W\&R housing system is a rare example of an innovative housing system that has been used repeatedly since it was first introduced onto the Dutch housing market. Therefore, insight into the factors that have been decisive in such a large-scale adoption, and repeated application over time, could prove immensely valuable in boosting the likelihood of future innovations achieving market success. Study IV contributes to the development of this insight by answering the following two sub-questions:

a) What differentiates the WER housing system from housing systems, which did not experience a continued adoption?

b) Which mechanisms contribute to a continued adoption over time and across housing projects? 
Study IV includes a longitudinal, in-depth case study into the W\&R housing system that has been applied in housing projects since 1992. Based on an extensive document study and in-depth structured interviews with stakeholders, how the W\&R housing system has developed over time was mapped, and which mechanisms had influenced its adoption identified.

As a robustness check, the findings were compared with three less successful industrial housing systems that had been launched on the market.

The conducted research shows that the W\&R system distinguishes itself from the three other innovative building systems by coherently organizing the acquisition, design, purchasing, production, on-site assembly and professional management of the successive phases in the housing construction process. The study highlighted the importance of maintaining a leading market position through low construction costs and keeping pace with changing market demands by further improving and developing the existing housing system. The W\&R housing system has evolved over the past thirty years from a focus primarily on standardization, to standardized variety, to product differentiation, and now also with additional services included as part of the W\&R system.

Study IV also showed that the possible adoption of an industrial building system takes place through a stage-gate selection process and that the likelihood of adoption is increased if:

1. The provider is regionally active;

2. A high-quality standard at a low cost (price-quality ratio) is offered;

3. The proposed technology is in line with what is customary in existing housing construction;

4. In addition to a low-cost guarantee, additional and distinctive functionalities are offered;
5. The housing system design is flexible and relatively easy to adapt when changing market needs arise.

Conclusions - The research started with the observation that to overcome the significant shortage of affordable, sustainable and circular houses in the Netherlands requires the adoption of innovative solutions to realize a far-reaching professionalization and industrialization of the housing sector. However, the innovation roadmap in the housing sector is paved with countless innovations that failed to be taken up by the market. From this, it was concluded that a much better insight into factors that may stimulate or hinder innovation adoption was needed. The insights that have been developed and described in this thesis may hopefully contribute to increasing the adoption rate of effective innovative solutions and through this, to boost the availability of affordable, sustainable and circular housing in the Netherlands. 


\section{Samenvatting}

Achtergrond - Industrialisatie, digitalisering en innovatie in de woningbouwsector zijn een "condicio sine qua non" om problemen zoals de toenemende vraag naar betaalbare huisvesting, de groeiende arbeidskrapte in de bouw, de belasting van het milieu door de bouw- en sloop van woningen en de snel veranderende marktbehoeften, het hoofd te kunnen bieden. Hiertoe zijn substantiële innovaties nodig die uiteenlopen van nieuwe bouwmaterialen en componenten tot complete huisvestingssystemen. Idealiter kunnen deze innovaties een bijdrage leveren aan het streven in de bouw tot het realiseren van kortere bouwtijden, lagere faalkosten en een hogere bouwkwaliteit, maar ook tot duurzame en circulaire gebouwen. Om van deze innovaties te kunnen profiteren, is het wel van belang dat ze op grote schaal kunnen worden toegepast.

Probleemstelling - De adoptie van een innovatie in de woningbouw kan worden gedefinieerd als het besluit om een innovatie van een product, proces of systeem toe te passen in een woningbouwproject. Ondanks inspanningen om innovaties in de woningbouw te ontwikkelen en te introduceren, is de markt nog steeds terughoudend om deze innovaties op grote schaal in de praktijk te brengen. Veel innovaties worden slechts op kleine schaal toegepast en verspreiden zich in de markt niet verder dan hun demonstratiestatus. Het blijft dus een uitdaging om ze op brede schaal toegepast te krijgen. De woningbouwsector lijkt niet los te kunnen komen van traditionele bouw- en uitvoeringstechnieken. Dit is problematisch omdat woningbouwprojecten nog immer geplaagd worden door kosten- en tijdoverschrijdingen, een lage productiviteit, inefficiëntie, kwaliteitsproblemen en bovendien een grote negatieve impact hebben op het milieu.
De Adviesraad voor Wetenschap, Technologie en Innovatie, een adviesorgaan van de regering, stelde in haar in 2018 uitgebrachte adviesrapport "Verspreiding, de onderbelichte kant van innovatie" dat er door onderzoekers en beleidsmakers onvoldoende aandacht is voor de adoptie en verspreiding van innovaties in de Nederlandse economie. De bouwsector wordt daarbij expliciet genoemd door de adviesraad. Diepgaande kennis van de adoptie van een innovatie in een woningbouwproject en vervolgens ook in daaropvolgende projecten zou een substantiële bijdrage kunnen leveren aan de adoptiegraad van innovatie in de sector. Uit eerder onderzoek bleek dat het moeilijk is om innovaties breed geaccepteerd te krijgen in de woningsector en dat algemene theorieën over de adoptie van innovatie de povere adoptie en acceptatie van innovatie onvoldoende verklaren. In dit verband is de hypothese gesteld dat innovatie niet kan worden begrepen buiten de context van haar ontwikkeling, adoptie en de daaropvolgende verspreiding. Kortom, inzichten m.b.t. de adoptie van innovatie zijn context-specifiek en niet zondermeer te kopiëren naar een andere sector. Als men de adoptie van een innovatie door stakeholders van een woningbouwproject wil begrijpen, moet rekening worden gehouden met de specifieke kenmerken van de woningbouwsector. Het ontbreekt in de literatuur vooralsnog aan context-specifieke, empirische gegevens over de mechanismen die de adoptie van verschillende soorten innovaties, op verschillende niveaus (adoptie door een individu, een bedrijf en adoptie in een project en / of de sector als geheel) beïnvloeden.

Doelstelling - Dit proefschrift heeft tot doel de kennis van de adoptie van innovaties in de woningbouwsector te vergroten. De nadruk ligt op het identificeren van de variabelen en mechanismen die van invloed zijn op de 
beslissing van belanghebbenden om innovaties in woningbouwprojecten toe te gaan passen. De bevindingen van dit proefschrift dragen daarmee bij aan de context-specifieke, wetenschappelijke kennis van de variabelen en mechanismen die de adoptie van verschillende soorten innovaties in de woningbouw beïnvloeden. Deze kennis kan bovendien managers en innovators in de woningbouw helpen om het adoptiepotentieel van hun technologische innovaties te vergroten. Het centrale doel van dit proefschrift kan worden samengevat met de volgende hoofdonderzoeksvraag:

"Welke variabelen en mechanismen beïnvloeden de adoptie van innovaties in de woningsector?"

In het proefschrift worden vier onderzoeken, respectievelijk Studie I, II, III en IV beschreven. Deze zijn uitgevoerd om bovenstaande hoofdvraag te beantwoorden.

\section{Studie I: een bibliometrische studie naar de adoptie van innovatie}

Studie I omvat een bibliometrische studie van de wetenschappelijke literatuur op het gebied van innovatie adoptie. In deze studie zij twee deelvragen beantwoord:

\section{a) Wat zijn de belangrijkste theorieën over de adopties van innovatie die als de hoekstenen van innovatie-adoptieonderzoek kunnen wor- den beschouwd? \\ b) Wat zijn de huidige onderzoektrends op het gebied van innovatie adoptie?}

Door toepassing van bibliometrische reviewtechnieken kon een groot aantal wetenschappelijke artikelen (1260 wetenschappelijke artikelen) worden geïdentificeerd, gestructureerd en geanalyseerd. De onderzoeksresultaten geven aan dat adoptieonderzoek voortbouwt op vier theoretische hoekstenen.

Deze zijn: A) Institutionele theorie en de legitimering van innovatief gedrag; B) "Reasoned
Action" theorie en het model voor de acceptatie van technologie; C) Studies naar de sociaal-econometrisch adoptievariabelen; en D) Diffusietheorie. Vervolgens zijn aan de hand van bibliografische technieken vijf dominante onderzoektrends geïdentificeerd: 1) Stimuli en belemmeringen voor de adoptie van informatietechnologie (ICT); 2) De adoptie en acceptatie van nieuwe technologiestandaarden; 3) Organisatorische redenen voor de adoptie van innovatie; 4) Modellering van het diffusieproces; en 5) Adoptie van landbouwinnovaties. Deze studie kan worden gezien als een duidelijke aanvulling op bestaand onderzoek naar innovatie adoptie. Ten eerste was het op basis van co-citatieanalyse mogelijk om te illustreren dat onderzoek naar innovatie-adoptie gebaseerd is op vier theoretische hoekstenen (of in termen van bibliografische clustering, vier clusters van eerdere publicaties). Ten tweede was het met bibliometrische koppeling mogelijk om de huidige onderzoektrends in de wetenschappelijke literatuur over innovatie-adoptie te identificeren. Ten derde werd een samenhangend raamwerk opgesteld waarmee de relevantie van innovatie-adoptieonderzoek kan worden beoordeeld. Studie I maakte ook duidelijk dat eerder uitgevoerde studies hebben bijgedragen aan het ontwikkelen van een coherent begrip van innovatie adoptie in specifieke onderzoeksgebieden. Tenslotte worden in Studie I ook diverse richtingen voor vervolgonderzoek benoemd.

\section{Studie II: een literatuurstudie naar de adoptie van innovatie in de woningbouw}

In tegenstelling tot Studie I, is in Studie II een narratieve, systematische literatuurstudie uitgevoerd. In deze studie is de navolgende deelvraag beantwoord:

Gezien eerder uitgevoerd onderzoek naar de adoptie van innovaties in de woningsector, welke specifieke variabelen blijken van invloed te zijn op de adoptie van innovaties in woningbouwprojecten? 
Op basis van de uitgebreide literatuurstudie kon een conceptueel innovatieadoptie model worden afgeleid bestaande uit vier hoofdcategorieën van adoptiedeterminanten met hun respectievelijke onderliggende variabelen. De onderscheiden vier categorieën betreffen de:

1. Invloed vanuit de externe omgeving;

2. Productkenmerken en innovatieattributen;

3. Kenmerken van de woningbouwsector;

4. Kenmerken van de adoptiebesluitvormer.

Deze vier categorieën omvatten in totaal 21 onderliggende variabelen. Deze kunnen in toekomstig onderzoek nader worden onderzocht op de mate van statistische relevantie. Op basis van het literatuuronderzoek was het ook mogelijk een taxonomie af te leiden van technologische innovaties die in woningbouwprojecten worden toegepast. Uit de ontwikkelde taxonomie blijkt, dat in tegenstelling tot incrementele, modulaire en systemische innovaties, er in de literatuur geen studies zijn uitgevoerd naar de adoptie van mogelijke radicale innovaties in de woningbouw.

\section{Studie III: een onderzoek naar de adoptie van modulaire innovaties in de woningbouw}

Modulaire productinnovatie wordt algemeen beschouwd als een veelbelovende strategie om te komen tot circulaire woningbouw en het kunnen ontwikkelen en aanbieden van op de klant toegesneden oplossingen binnen een geïndustrialiseerde woningbouw. Ondanks de potentiële toegevoegde waarde van modulariteit in de woningbouw, worden modulaire bouwconcepten nog altijd niet op grote schaal toegepast in de woningbouw. Er is ook nog weinig empirisch onderzoek beschikbaar over de adoptie (of juist de afwijzing) van modulaire bouwconcepten in de woningsector. Gegeven deze lacune, zijn in deze studie twee deelvragen onderzocht:

\section{a) Welke mechanismen beïnvloeden de adoptie van modulaire innovatie in de woningsector?}

b) In hoeverre kan de theorie over modulariteit helpen om de adoptie van modulaire innovatie in de woningsector te verklaren?

De meervoudige casestudy uitgevoerd in Studie III is gericht geweest op het identificeren van de mechanismen en de onderliggende variabelen die bepalend zijn voor de adoptie van modulaire innovaties in de Nederlandse woningbouwsector. In Studie III is de adoptie onderzocht van respectievelijk een modulair duurzaam klimaatsysteem, een modulair geprefabriceerde badkamer en een geïntegreerd fotovoltaïsch modulair dak. Naast een uitvoerige literatuurstudie op het gebied van modulariteit en het doornemen van relevante documenten, was het mogelijk om met behulp van expertinterviews en focusgroepen de variabelen en mechanismen te identificeren die de adoptie van de drie modulaire innovaties beïnvloeden. Uit de meervoudige casestudy kwamen 10 variabelen naar voren die van invloed zijn op de adoptie van de drie genoemde modulaire innovaties in woningbouwprojecten. Door deze 10 variabelen in hun onderlinge samenhang voor de drie casestudies verder te analyseren, konden vier causale mechanismen worden afgeleid die bepalend zijn voor de mogelijke adoptie van modulaire innovaties in woningbouwprojecten. Dit heeft geleid tot vier proposities die in toekomstig onderzoek nader kunnen worden getoetst. Uit Studie III bleek tenslotte dat voor de adoptie van een modulair innovatief product, het productontwerp goed moet zijn afgestemd met de toeleveringsketen en ook moet passen binnen het beoogde realisatieproces van de woning als geheel.

\section{Studie IV: een onderzoek naar een herhaalde en opgeschaalde adoptie van bouwsystemen}

Uit Studie II bleek dat er een groot aantal wetenschappelijke publicaties verschenen zijn over de adoptie van innovaties in de woningbouw. Helaas worden deze innovaties veelal slechts op kleine schaal toegepast en verspreiden zij zich in de markt veelal niet verder dan hun demon- 
stratiestatus. Het W\&R-woningbouwsysteem, is een zeldzaam voorbeeld van een innovatief woningbouwsysteem dat sinds het voor het eerst op de Nederlandse woningmarkt werd geïntroduceerd, nog altijd herhaaldelijk wordt toegepast. Inzicht in de factoren die bepalend zijn geweest voor een dergelijke grootschalige adoptie en in de tijd herhaalde toepassing is daarom essentieel. Studie IV levert een bijdrage aan het ontwikkelen van dit inzicht door de volgende twee deelvragen te beantwoorden:

\section{a) Wat onderscheidt het WER-woningbouwsys- teem van systemen, die niet continu zijn geadopteerd? \\ b) Welke mechanismen dragen bij tot een her- haalde adoptie in de tijd in woningbouwpro- jecten?}

Studie IV omvat een longitudinale, diepgaande casestudy naar het sinds 1992 herhaaldelijk in woningbouwprojecten toegepaste W\&R woningbouwsysteem. Op basis van een uitvoerige documentenstudie en diepgaande gestructureerde interviews met stakeholders is in kaart gebracht hoe het W\&R-systeem zich in de loop van de tijd heeft ontwikkeld en welke mechanismen de adoptie ervan hebben beïnvloed. Ook is onderzocht waarin het W\&R systeem zich onderscheidt van een drietal andere woningbouwsystemen die nimmer hebben geleid tot grootschalige toepassing en niet verder kwamen dan hun demonstratiestatus.

Uit het uitgevoerde onderzoek blijkt dat W\&R zich onderscheidt van de drie andere innovatieve bouwsystemen door een coherente organisatie van de acquisitie, het ontwerp, de inkoop, productie, on-site assemblage, en het professioneel managen van de opeenvolgende fasen in het woningbouwproces. Uit de studie blijkt het belang van het behouden van een leidende marktpositie met betrekking tot naar verhouding lage bouwkosten en het gelijke tred houden met een veranderende marktvraag door het bestaande huisvestingssysteem hierop verder te verbeteren en te ontwikkelen.
Het W\&R-woningbouwsysteem is in de afgelopen dertig jaar geëvolueerd van een focus die voornamelijk op standaardisatie lag, naar gestandaardiseerde variëteit, naar productdifferentiatie, en nu ook naar het aanbieden van aanvullende diensten als onderdeel van het W\&R-systeem.

Studie IV maakte ook duidelijk dat de mogelijke adoptie van een industrieel bouwsysteem verloopt via een stapsgewijs selectieproces en dat de adoptiekans wordt verhoogd naarmate: (1) de aanbieder regionaal actief is; (2) een hoge kwaliteitsstandaard tegen lage kosten (prijskwaliteit verhouding) wordt aangeboden; (3) dat de voorgestelde technologie aansluit bij het hetgeen gebruikelijk is in de bestaande woningbouw; (4) naast een lage kostengarantie, aanvullende onderscheidende extra functionaliteiten worden aangeboden; (5) het woningbouwsysteem flexibel en relatief eenvoudig aanpasbaar is bij het zich aandienen van veranderende marktbehoeften.

Conclusie - Het vertrekpunt van dit onderzoek was de constatering dat het grote tekort aan betaalbare, duurzame en circulaire woningen in Nederland vraagt om de adoptie van innovatieve oplossingen om een verregaande professionalisering en industrialisatie van de woningsector te realiseren. De innovatieroutekaart in de woningsector is echter geplaveid met talloze innovaties die niet in de markt op grote schaal zijn toegepast. Teneinde hierin verandering aan te brengen, is een veel beter inzicht nodig in de variabelen en mechanismen die de adoptie van innovatie kunnen stimuleren of belemmeren. De in dit proefschrift ontwikkelde en beschreven inzichten op het gebied van de adoptie van innovaties in de woningbouw kunnen hopelijk bijdragen aan het verhogen van de relatief lage adoptiegraad van innovaties in de woningbouw en het verminderen van het tekort aan betaalbare, duurzame en circulaire woningen in Nederland. 


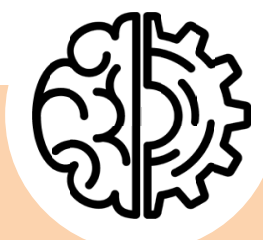

\section{Table of content}

Summary

Samenvatting

Table of content

\section{List of Figures}

1.1 Background to the Dutch housing market

1.2 A poor adoption of innovation in housing

1.3 The aim of this research

1.4 Research sub-questions and methods: four studies

1.5 Outline of the thesis

2 A bibliometric review of the innovation adoption literature

$\begin{array}{lll}2.1 & 35\end{array}$

$2.2 \quad$ Data and Methods $\quad 37$

$2.3 \quad$ Cornerstones of innovation adoption research 43

2.4 Analysis of innovation adoption research trends based on bibliographic coupling 57

2.5 Summary, future research and limitations 70

$3 \quad$ Getting innovations adopted in the housing sector $\quad 75$

$\begin{array}{lll}3.1 & 7 n \text { Inoduction } & 77\end{array}$

$\begin{array}{lll}3.2 & \\ & \text { Methodology }\end{array}$

3.3 A Taxonomy of the adoption of innovation in housing literature 82

3.4 Mechanisms affecting the adoption of innovation in housing 88

3.5 Contribution, implications, limitations and research agenda 100

$\begin{array}{lll}3.6 & \text { Conclusion } & 103\end{array}$ 
4 The adoption of modular innovations in the Dutch housing sector

$\begin{array}{lll}4.1 & 107\end{array}$

$\begin{array}{lll}4.2 & \text { Literature background } & 108\end{array}$

$\begin{array}{llr}4.3 & \text { Research methodology } & 115\end{array}$

$\begin{array}{llr}4.4 & \text { Findings } & 118\end{array}$

$\begin{array}{lll}4.5 & \text { Discussion and conclusions } & 133\end{array}$

5 The Continued Adoption of Housing Systems in the Netherlands 139

$\begin{array}{lll}5.1 & 141\end{array}$

$\begin{array}{ll}5.2 & 142\end{array}$

$\begin{array}{lll}5.3 & \text { Research Method } & 144\end{array}$

$\begin{array}{lll}5.4 & \text { The Stage-Gate Selection Process } & 147\end{array}$

$\begin{array}{llr}5.5 & \text { The W\&R Housing System } & 149\end{array}$

5.6 Cross-case Analysis: Deriving Mechanisms of Continued Adoption 155

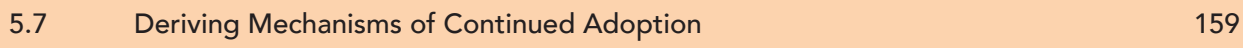

$\begin{array}{lll}5.8 & \text { Discussion and conclusion } & 166\end{array}$

$6 \quad$ Conclusions, main contributions, implications and future research 169

$\begin{array}{lll}6.1 & \text { Research questions and methods } & 171\end{array}$

$\begin{array}{lll}6.2 & \text { Summary of the main scientific contributions } & 173\end{array}$

$\begin{array}{lll}6.3 & \text { Managerial and policy implications } & 176\end{array}$

$\begin{array}{lll}6.4 & \text { Directions for future research } & 178\end{array}$

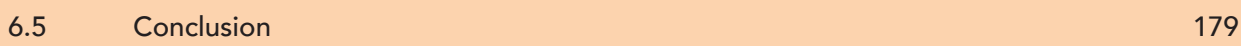

$\begin{array}{lr}\text { References } & 181\end{array}$

Appendix A: Systematic Review Protocol $\quad 202$

Appendix B: Overview articles included in the systematic narrative literature review 203

Dankwoord (Acknowledgements in Dutch) 210

$\begin{array}{lr}\text { About the author } & 212\end{array}$

$\begin{array}{lr}\text { Academic output } & 213\end{array}$ 


\section{List of Figures}

Figure 1.1: General statistics about the Dutch housing market

Figure 1.2: Number of newly constructed homes in the Netherlands 2000-2019

Figure 1.3: Coherence between the four studies conducted in this thesis

Figure 1.4: An overview of the four innovation adoption studies

Figure 2.1: The number of scientific articles about innovation adoption

Figure 2.2: Number of scientific articles about innovation adoption

Figure 2.3: Illustration of co-citation analysis

Figure 2.4: Illustration of bibliographic coupling

Figure 2.5: Co-citation network of references.

Figure 2.6: Bibliographic network of innovation adoption publications

Figure 2.7: Number of publications per year per cluster

Figure 2.8: Cross reference of 49 recently published reviews

Figure 3.1: Conceptual model of the systematic review

Figure 3.2: A conceptual framework of innovation adoption in the housing sector

Figure 3.3: A coherent framework

Figure 4.1: First proposed causal mechanism

Figure 4.2: Second proposed causal mechanism

Figure 4.3: Third proposed causal mechanism

Figure 4.4: Fourth proposed causal mechanism

Figure 4.5: The system boundaries of a modular housing system

Figure 5.1: The stage-gate decision making process for realizing housing projects

Figure 5.2: The Number of constructed dwellings by the W\&R housing system

Figure 5.3: Development of the W\&R housing system.

Figure 5.4: Timeline Concrete Slab House system

Figure 5.5: Timeline Wood Pod House 


\section{List of Tables}

Table 2.1: Most cited review, overview and meta-analysis articles on adoption

Table 2.2: Overview of the 44 publications in Cluster A

Table 2.3: Determinants of innovation adoption

Table 2.4: Indicators of publication output and citation impact

Table 2.5: Overview of the 5 identified bibliographic coupled clusters

Table 2.6: Battle for dominance between two technology standards

Table 2.7: Indicators of publication output and citation impact per thematic cluster

Table 3.1: Overview of scientific journals

Table 3.2: Articles included in this review sample

Table 3.3: Research methodologies applied in articles included in the review sample

Table 3.4: Overview of theoretical concepts applied

Table 3.5: A taxonomy of innovation types in the housing sector

Table 3.6: Determinants of relative advantage in the context of housing

Table 3.7: Determinants of the principal-agent inertia

Table 3.8: Project(-site) specific issues affecting innovation adoption in housing

Table 4.1:Characteristics of three types of supply chain set-ups found in housing

Table 4.2: Modularity types and suggested indicators

Table 4.3: Overview of data sources per case

Table 4.4: Description of the products studied;

Table 4.5: Variables affecting the adoption of modular innovations

Table 4.6: Cross reference table of adoption variables

Table 5.1: Client considerations during the stage-gate decision-making process

Table 5.2: Case study findings about identified determinants of continued adoption 



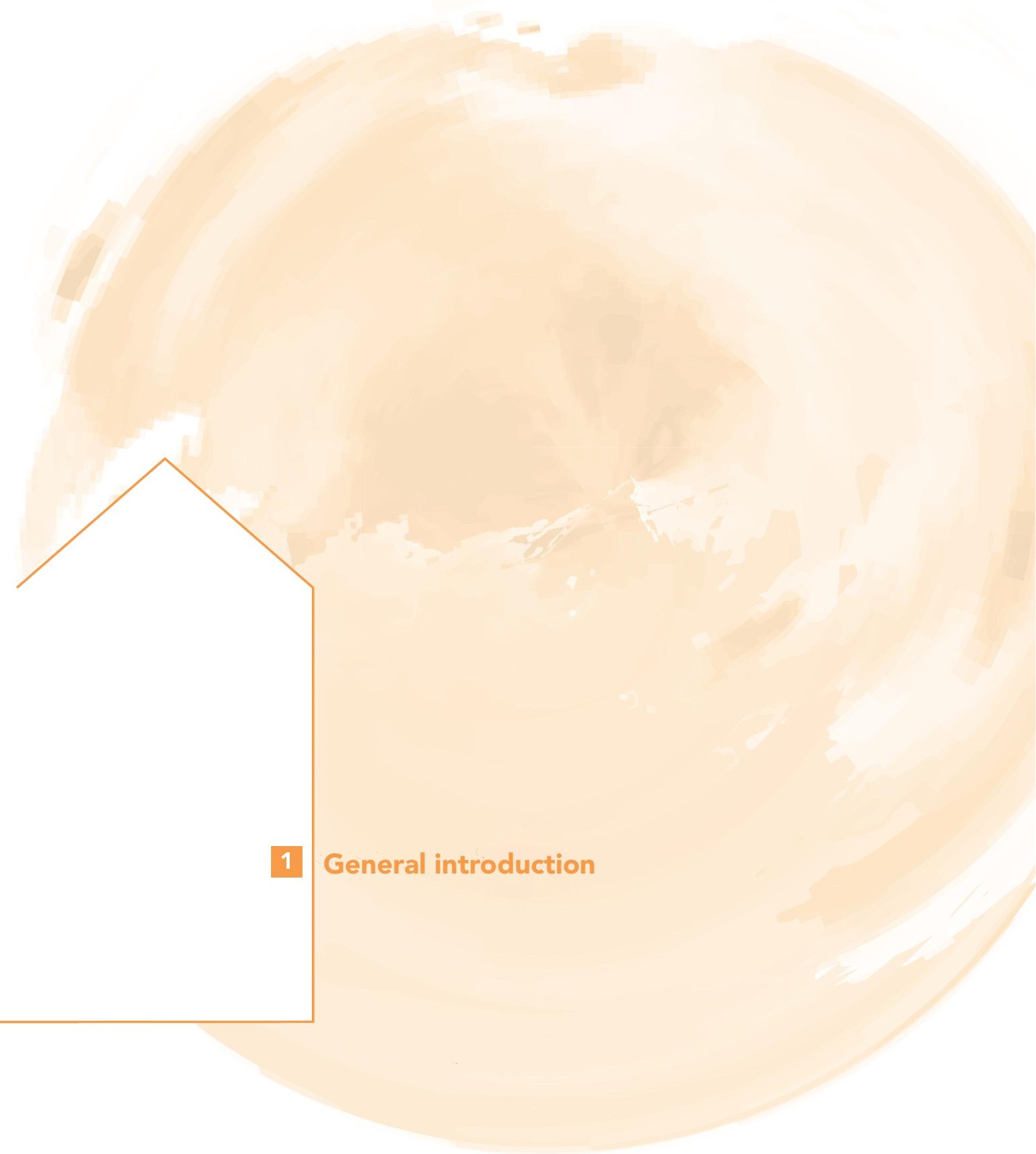




\section{General introduction}

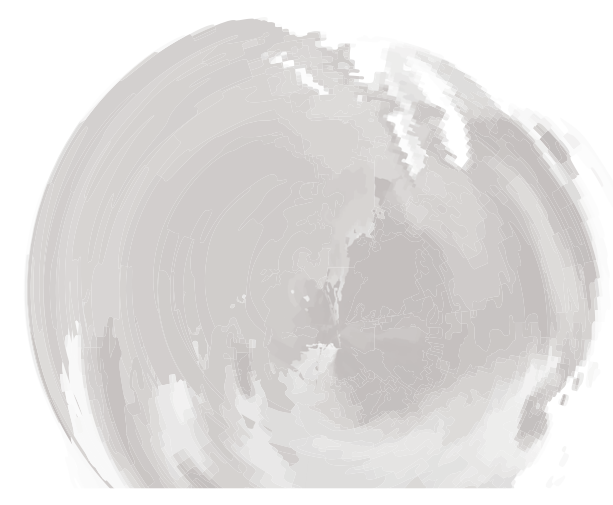

This opening chapter serves as an introduction to the research presented in this thesis. The first two sections shed light on some core challenges facing the Dutch housing market. Industrialization, digitalization and innovation are considered key to overcoming these challenges. Section 1.3 explains the need and the conditions for innovation in the housing sector. Section 1.4 defines the field of study and Section 1.5 presents the main research objectives and provides an introduction to the four studies that form the main body of this thesis in the subsequent chapters. The chapter concludes with an outline of the overall thesis. 


\subsection{Background to the Dutch housing market}

The total Dutch housing stock consisted of some 7.8 million homes in $2019^{1}$ (BZK, 2019; Faessen et al., 2017). About 5 million of these are single family households and about 2.8 million homes are in multi-family buildings (see also Figure 1.1). Homes in the Netherlands are relatively spacious compared to other EU countries. Single family houses offer an average of 145 square metres of living space (i.e. gross floor area) and apartments have on average 78 square metres living space.

The housing market can be segmented into social housing, commercial real estate and privately owned housing, with roughly 2.3 million, 1.1 million and 4.4 homes respectively (see Figure 1.1). Households by number of occupants are divided as follows: 3 million $(38.5 \%)$ are one-person households, 2.2 million (28\%) are two-person households, 2 million $(25.5 \%)$ are family homes (two parents plus children) and 620,000 (8\%) are inhabited by single-parent households.

Housing market segment

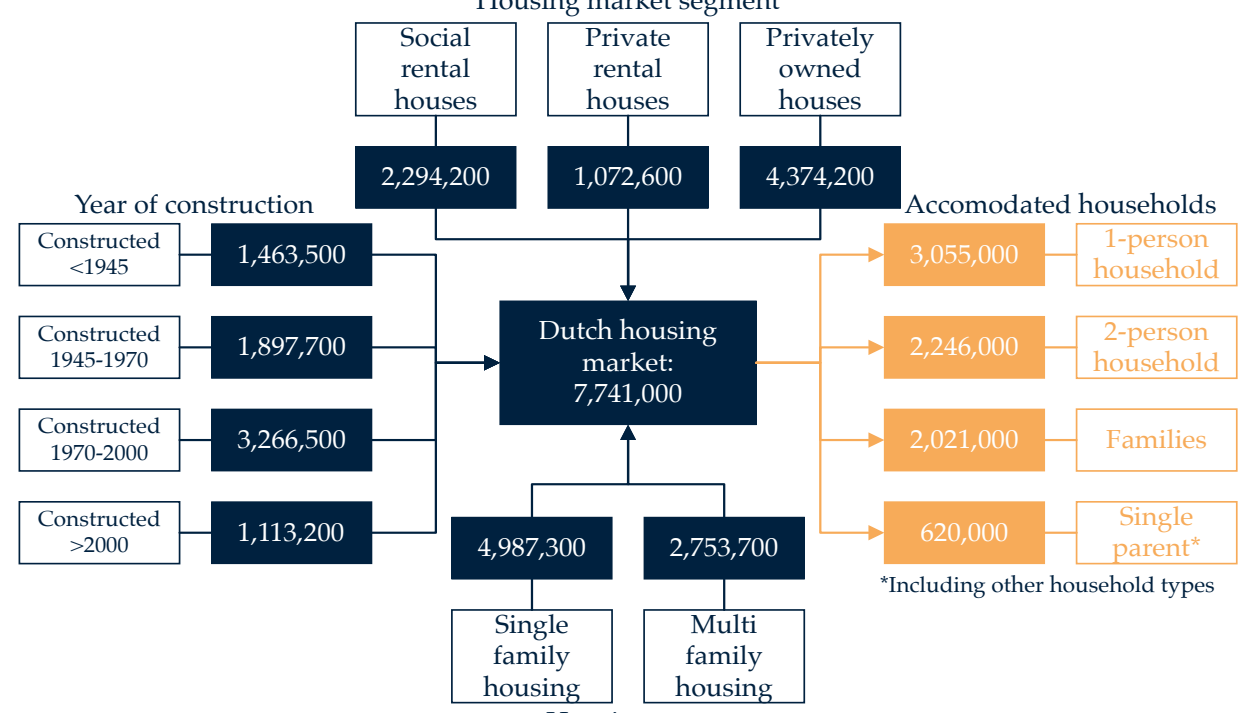

Housing type

Figure 1.1: General statistics about the Dutch housing market (adapted from Cijfers over Wonen en Bouwen (2019))

About $81 \%$ of the Dutch housing stock has been built since World War II. The Dutch housing stock continues to grow through the construction of new housing and the transformation of existing buildings (such as vacant office buildings being converted into apartment buildings). Between 2000 and 2009, the housing stock grew by more than 1 percent annually on average, with an average of around 76,000 new homes per year. In the decade that followed, at the lowest point, in 2014 (due to the credit crisis), the growth was just 0.6 percent (45,000 new-build homes).

1. Statistics on the Dutch housing market were derived from reports published by the Ministry of Internal Affairs (Cijfers over Wonen en Bouwen) and the research institute ABF Research (Primos).

The database https://vois. datawonen.nl//was also consulted. 
In the five years that followed, the number of new-build homes grew year on year (see Figure 1.2). In 2019, nearly 71,000 new-build homes were completed, the highest number in ten years. However, due to the global Covid-19 crisis it is expected that the number of new houses will fall dramatically in the coming years. Besides new-builds, about 71,420 homes were added in the period 2012-2018 by the transformation of existing buildings such as schools, offices and shops (Swart et al., 2019). In the opposite direction, a substantial number of homes were withdrawn from the total stock in this period. In total, 130,833 homes were demolished in the period 2012-2019 and a further 350,399 housing units were withdrawn for other reasons such as a change in function, a fire or the combination of two units into a single housing unit $^{2}$.

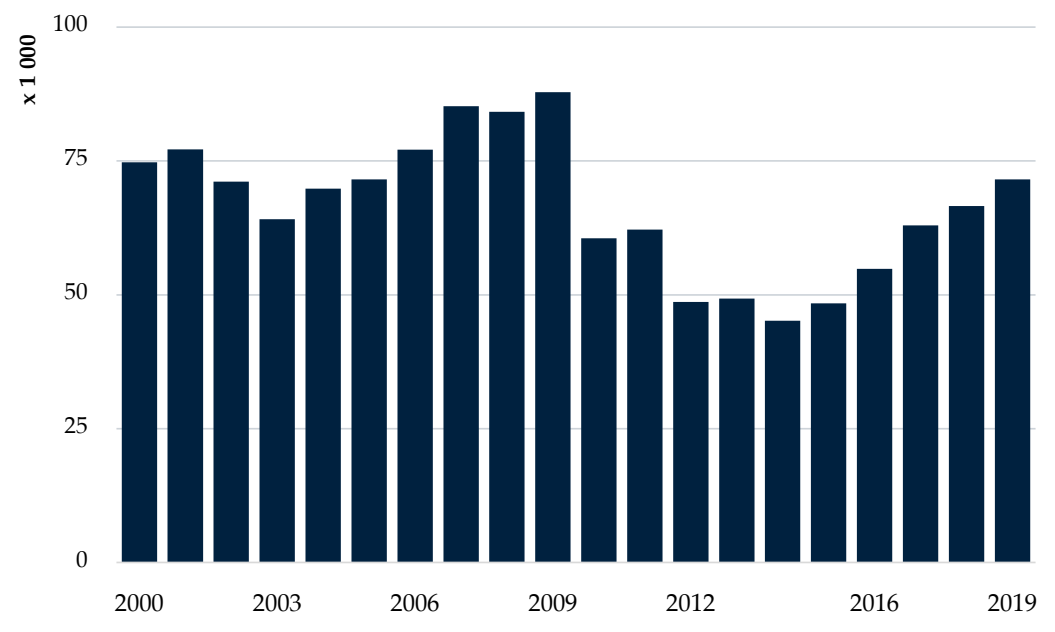

Figure 1.2: Number of newly constructed homes in the Netherlands 2000-2019 ${ }^{3}$

A sharp increase in housing demand as a result of various demographic developments (population growth, immigration, decrease in the number of persons per household) and a substantial decline in house building since the credit crisis (2007-2011) has resulted in a considerable housing shortage in the Netherlands. To close this gap, the Dutch government determined, in its National Housing Agenda (BZK, 2018a, b), to build 75,000 homes per year in the period 2020-2025. In addition, it has been forecast that, for the period 20252050 , on a yearly basis, 51,000 homes need to be constructed while about 14,000 homes will be withdrawn, leading to a net growth of 37,000 homes annually.

Substantial job losses after the credit crisis led to a decline in production capacity, and so satisfying this pressing and imminent need for increased housing production can only be achieved through a significant increase in industrialization.

2. CBS Statline (Voorraad woningen en niet-woningen; mutaties, gebruiksfunctie, region), 25 February 2020.

https://www.cbs.nl/nl-nl/cijfers/detail/81955NED?dl=3A0E3

3. CBS Statline (Voorraad woningen; standen en mutaties vanaf 1921), 29 May 2020,

https://opendata.cbs.nl/\#/CBS/nl/dataset/82235NED/table?ts=1593020986617 
Undertaking the majority of the work in a controlled factory environment, before on-site assembly, reduces complexity and increases quality and productivity. Drawing on expert interviews and industry observations, McKinsey $(2017 ; 2019)$ estimated that prefabrication and modularization has the potential to boost productivity between five and tenfold, and can speed construction by as much as fifty percent because productivity is higher in a controlled environment, such as a factory, than on site. Prefabricated parts can also offer higher safety, better quality and lower rework rates since the manufacturing process enables more efficient and faster inspections and quality checks. The increased use of manufacturing technology and automation can also reduce human error and increase consistency. This ensures that prefabricated parts and units arrive on site in a condition that requires little remedial work before or during assembly, thus reducing build time.

Alongside the persistent housing shortage, three additional challenges drive the transition towards modularization and industrialization in housebuilding. The first challenge concerns carbon emissions in the built environment, which amount to about $40 \%$ of total $\mathrm{CO}_{2}$ emissions, and the fact that about $27 \%$ of energy consumption takes place in residential buildings. More stringent regulations and an enormous effort to upgrade the existing housing stock to substantially reduce national energy consumption will be necessary in the coming years (Arnoldussen et al., 2017). Second, the construction sector uses more than half of all the materials used in the Netherlands, and generates more than 25 million tonnes of waste. Only 3\% of demolition waste is reused or recycled in the construction of new buildings (Schut et al., 2015). In line with national policies, the housing sector is about to enter a transition to achieve fully circular construction by 2050 (Rijksoverheid, 2019; Rijskoverheid, 2019). Third, changing housing requirements also need to be taken into account given the trend towards smaller households. This is due to an aging population, the growth in the number of one-person households and also the international migration in recent decades, which together have led to a greater diversity in residential preferences (Arnoldussen et al., 2017). Overall, these changes require the development and implementation of substantial innovations in the housing sector.

\subsection{A poor adoption of innovation in housing}

There seems to be a consensus that innovation involves (1) a novelty, (2) of a certain magnitude, (3) with a certain level of performance improvement that (4) needs to be adopted and implemented (see e.g. Lenderink et al. (2020); Slaughter (1998); Van de Ven (1986)). Based on Rogers' conceptualization of adoption (2003)4, innovation adoption in the housing sector can be defined as the decision to apply a product, process or system innovation in a housing project.

4. The adoption-diffusion literature can be traced back to the work of Gabriel Tarde, a French sociologist, who introduced the Laws of Imitation at the beginning of the 1900s (Tarde (1903). However, only when Everett Rogers (Rogers, 1962) introduced the Diffusion of Innovations Theory (DOI) did adoption and diffusion research gain widespread recognition. 
Many attempts, often supported by extensive national ${ }^{5}$ and international ${ }^{6}$ governmental programmes, have been and are still undertaken to develop innovative solutions to improve the industrialization, customization and sustainability of housebuilding. Despite the social and institutional pressures to develop and introduce such innovations in

housing, the market remains reluctant to innovate. Innovations which have been developed and introduced successfully are often only adopted on a small scale, and lack a continued large-scale diffusion beyond the sphere of influence of their innovators. This seems particularly the case with respect to modularization and industrialization of housebuilding (Arnoldussen et al., 2017; Boschman, 2016; Slaughter, 1998; Van Beek et al., 2016; Wientjes et al., 2017; Winch, 1998; Zeijlemaker et al., 2015). This low adoption of innovation is particularly problematic given the pressing need to comply with housing policies that address a growing shortage of affordable housing and environmental issues ${ }^{7}$. Therefore, housing not only needs to be produced in higher volumes and produced and/or renovated at lower costs and at higher quality standards, but also needs to be constructed or renovated in a sustainable and circular way.

\section{Problem statement:}

The limited adoption of technological innovations is problematic given the pressing need to construct high volumes of affordable, sustainable and circular housing.

There has been a long history of technologically superior solutions that were not picked up by the construction sector (Winch, 1998). Scholars in the field of construction innovation refer to the conservatism, negative attitudes or even recalcitrant behaviour of construction firms towards innovation (Blayse and Manley, 2004; Oster and Quigley, 1977; Seaden and Manseau, 2001; Tatum, 1987; Teizer et al., 2011). Typical of a low-tech industry, the housing sector faces severe lock-in to traditional construction practices (Koebel et al., 2015; Lovell and Smith, 2010; Lutzenhiser, 1994; Xue et al., 2014). Moreover, the Science, Technology and Innovation Council (in Dutch: Adviesraad voor Wetenschap, Technologie en Innovation), an advisory board of the Dutch government, stated that the adoption and diffusion of innovation is not sufficiently addressed by research and policymaking in the Dutch economy, including the construction industry. Today, governmental officials are focussed on overcoming the institutional barriers that hinder the diffusion of innovation in the market (AWTI, 2018; EZK, 2018; Wientjes et al., 2017).

However, if one wants to truly understand the adoption of an innovation within a housing project, and subsequently by the involved firms, a more in-depth understanding is required about the mechanisms that affect adoption.

5. Such as the Open Building, Industrial Flexible Demountable (IFD) building and the recent Zero Energy housing (in Dutch: Nul-op-de-Meter, which is supported by the Stroomversnelling covenant)

6. The European Commission launched the 'Horizon 2020' (H2020) research and innovation programme in 2014

The EU strategy, including the H2O2O programme, affects innovation and research in various sectors including the construction and housing industry.

7. In addition to the need to construct 75,000 homes annually in the period 2020-2025, 270,000 homes also need to be renovated each year in accordance with climate policies to arrive at a zero-energy built environment in 2050 (Van Nunen, 2017). 
What is particularly missing is context-specific empirical data on the mechanisms that affect the adoption of various types of innovation across different levels of adoption (individual, firm, project and/or sector) during the different stages of diffusion ranging from market introduction to continued adoption.

\subsection{The aim of this research}

It was noted in Section 1.2 that it seems difficult to get innovations widely adopted in the housing sector, and general innovation adoption theories insufficiently explain the poor uptake of innovation. In this respect, previous research suggests that innovation cannot be understood beyond the context of its development, adoption and subsequent diffusion (Downs and Mohr, 1976; Harty, 2005). That is, if one wants to understand the possible adoption of an innovation by stakeholders who are involved in housing projects, one has to consider the structural characteristics of the housing sector (Lindgren, 2018; Sheffer,

2011; Taylor, 2005). Given that the aim of this thesis is to enhance understanding of the adoption of various types of technological innovation in the housing sector, the emphasis is placed on uncovering the variables and mechanisms that influence the decision by construction stakeholders on adopting technological innovations in their housing projects. The findings of this thesis will hopefully advance the limited understanding of these variables and mechanisms. A better understanding of the variables and mechanisms that hinder or stimulate the adoption of innovation will also provide insight to the innovators and beneficiaries concerning how they can increase the likelihood of having innovations adopted in the housing sector. The aim of this thesis research is summarized in the following main research question:

\section{"Which variables and mechanisms affect the adoption of innovation in the housing sector?"}

To address this main research question, this research starts with a general overview of the adoption of innovation research field (Study I), followed by a more detailed overview of the innovation adoption literature specific to the housing sector (Study II). Here, modularity is considered an essential step to arrive at industrial house building. Moreover, modularity is also considered a key strategy to overcome the fragmentation barrier (i.e. the complexity of managing numerous interfaces within temporal, loosely coupled multi-actor project teams) and improve long-term collaboration to sustain innovation and innovation adoption. Consequently, the adoption of innovative modular products 8 in housing projects will specifically be researched (Study III). However, the housing sector will only arrive at industrial housebuilding practices if relevant innovations achieve continuous adoption.

8. Modular innovations are characterised in this thesis as a one-to-one mapping between functions and physical subsystems and have standardized, decoupled interfaces that can be combined in different ways to configure product variants without the need to physically change adjacent subsystems (Salvador, 2007; Ulrich, 1995). 
Therefore, the continued adoption of industrial house building systems ${ }^{9}$ will be researched in a longitudinal study including cases of both success and failure (Study IV). Figure 1.3 illustrates the coherence between the four studies.

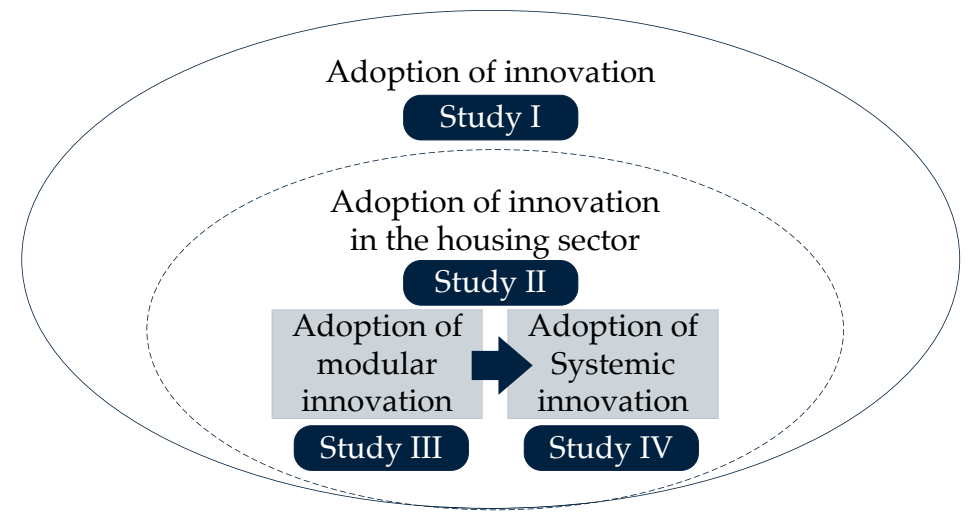

Figure 1.3: Coherence between the four studies conducted in this thesis

\subsection{Research sub-questions and methods: four studies}

This thesis is subdivided into four subsequent studies, referred to as Studies I, II, III and IV. These four studies aim to contribute to the understanding of innovation adoption in the housing sector. Figure 1.4 provides an overview of the four studies with their respective research sub-questions.

\begin{tabular}{|c|c|c|c|}
\hline $\begin{array}{c}\text { Study 1: } \\
\text { Bibliometric } \\
\text { review }\end{array}$ & $\begin{array}{c}\text { Study 2: } \\
\text { Systematic, } \\
\text { narrative review }\end{array}$ & $\begin{array}{c}\text { Study 3: } \\
\text { Multiple-case } \\
\text { study }\end{array}$ & $\begin{array}{c}\text { Study 4: } \\
\text { Longitudinal } \\
\text { case study }\end{array}$ \\
\hline $\begin{array}{l}\text { 1.What are the key } \\
\text { theoretical } \\
\text { cornerstones of } \\
\text { innovation adoption } \\
\text { research? }\end{array}$ & $\begin{array}{l}\text { 3. Which } \\
\text { determinants affect } \\
\text { the adoption of } \\
\text { innovation in the } \\
\text { context of housing } \\
\text { projects? }\end{array}$ & $\begin{array}{l}\text { 4. Which mechanisms } \\
\text { affect the adoption of } \\
\text { modular innovation } \\
\text { when introduced in } \\
\text { the housing sector? }\end{array}$ & $\begin{array}{l}\text { 6. What differentiates } \\
\text { the W\&R housing } \\
\text { system from housing } \\
\text { systems, which did } \\
\text { not experience a } \\
\text { continued adoption? }\end{array}$ \\
\hline $\begin{array}{l}\text { 2. What are the } \\
\text { current research } \\
\text { trends within the } \\
\text { field of innovation } \\
\text { adoption? }\end{array}$ & & $\begin{array}{l}\text { 5. To what extent can } \\
\text { the theory on } \\
\text { modularity help to } \\
\text { explain the adoption } \\
\text { of modular } \\
\text { innovation? }\end{array}$ & $\begin{array}{l}\text { 7. Which } \\
\text { mechanisms } \\
\text { contribute to a } \\
\text { continued adoption } \\
\text { over time and across } \\
\text { housing projects? }\end{array}$ \\
\hline
\end{tabular}

Figure 1.4: An overview of the four innovation adoption studies with their respective research sub-questions

9. Industrial housebuilding systems are viewed as systemic innovation. Systemic innovations alter the interfaces between the modules or the overall system architecture and require multiple firms in the supply chain network to change their design, prefabrication and/or assembly practices in a coordinated way (Hall et al., 2018; Lindgren, 2016). 


\section{Study I: Identifying the theoretical cornerstones and current research trends in innovation adoption research}

Innovation adoption is of the utmost importance for company survival. For this reason, it is important to develop a thorough understanding of innovation adoption and the themes it encapsulates. Since the early work in the 1960s by Everett Rogers, the adoption of innovation has attracted considerable attention and the field has continued to grow rapidly, resulting in a large but fragmented body of literature. The goal of Study I is to provide a coherent overview of the theoretical underpinnings as well as recent research trends in the innovation adoption literature. To this end, a bibliometric review has been conducted, alongside a bibliographic coupling and co-citation analysis. The co-citation analysis revealed that innovation adoption research is built on four theoretical cornerstones: institutional theory; theory of reasoned action; theory concerning the determinants of adoption; and diffusion theory. Bibliographic coupling was used to assess the current research trends. Based on this review, it became possible to identify thematic areas in an exhaustive manner that revealed five clusters of theme-related publications or "research trends". These are: determinants of IT adoption; adoption of technological standards; organizational rationales associated with adoption; modelling diffusion; and adoption of agricultural innovations. Study I concludes with the current limitations and future research orientations in the field of innovation adoption.

Study II: Development of a coherent innovation adoption framework in the housing sector

In contrast to the first study, Study II is based on a narrative systematic literature review concerning the adoption of innovation in the housing sector. The purposes of Study II are threefold. First, to provide a taxonomy of innovations in the housing sector. Second, to create a coherent framework including the mechanisms that stimulate and hinder the adoption of innovation in the housing sector. Third, to develop propositions for subsequent innovation adoption research. The created framework not only provides an explanatory overview of innovation adoption in the housing sector, it also provides insights for innovation managers on how to increase the likelihood of getting their innovations adopted in the housing sector.

Study III: Identifying the key adoption mechanisms for modular innovations in the housing sector

Study III involves a multiple case study to reveal the mechanisms that influenced the adoption of three modular innovations. The adoption of modular innovations in the housing sector is important not only because it enables mass-customization of housing designs and construction, but also because it allows adaptation, disassembly and reuse. As such, it can contribute to realizing a circular building stock. Study III includes an extensive literature review and an in-depth multiple case study. 
For the multiple case study, three innovative modular housing solutions were selected - a modular renewable energy system, a modular bathroom pod and an integrated photovoltaic modular roof. The multiple case study helped to identify ten variables that influence the adoption of such modular products. A detailed analysis revealed that several of these variables appeared to be interrelated. Based on this analysis, four causal mechanisms were deduced that determine the potential adoption of modular innovations. Study III is among the first in-depth empirical studies to link innovation adoption to modularity theory. It is also the first to investigate the internal causality of adoption variables in housing projects, and this enables an explanation of how and why modular housing products are adopted.

\section{Study IV: Identifying the key adoption mechanisms of an industrial housing system}

It appears challenging for housebuilding firms to move beyond a demonstration stage and get their housing systems adopted on a large scale and over an extended period. Study IV was designed to investigate the ongoing adoption of innovative industrial housing systems. It is based on a longitudinal, in-depth case study of a housing system which has been in continuous adoption since 1992 in multiple projects across the Netherlands. Here, an analysis was made of the reasons for this continued adoption in contrast to three other industrial housing systems that failed to maintain a place in the market. The case study findings show that at least five mechanisms played a determining role in the eventual continued adoption.

These are: the regional presence of the builder; the builder's operational excellence; a natural fit with existing technology standards; a competitive added value; and the ability of the housebuilder to keep pace with changing market requirements. An important lesson from this study is that, for continued adoption, one needs to stay alert and adapt the housing system to changing market requirements.

\subsection{Outline of the thesis}

The remainder of this thesis consists of five chapters. The research findings of Studies I, II, III and IV are reported in a series of papers respectively presented in Chapters 2, 3, 4 and 5. The papers presented in Chapters 2, 3, an 5 have been published in peer-reviewed scientific journals: in Technological Forecasting and Social Change; in Construction Innovation; and in the Journal of Construction Engineering, Management \& Innovation, respectively. The paper presented in Chapter 4 is currently under peer review for publication in a scientific journal. To round off the thesis, Chapter 6 summarizes the main contributions and discusses the implications for future research and the management of innovation adoption. 



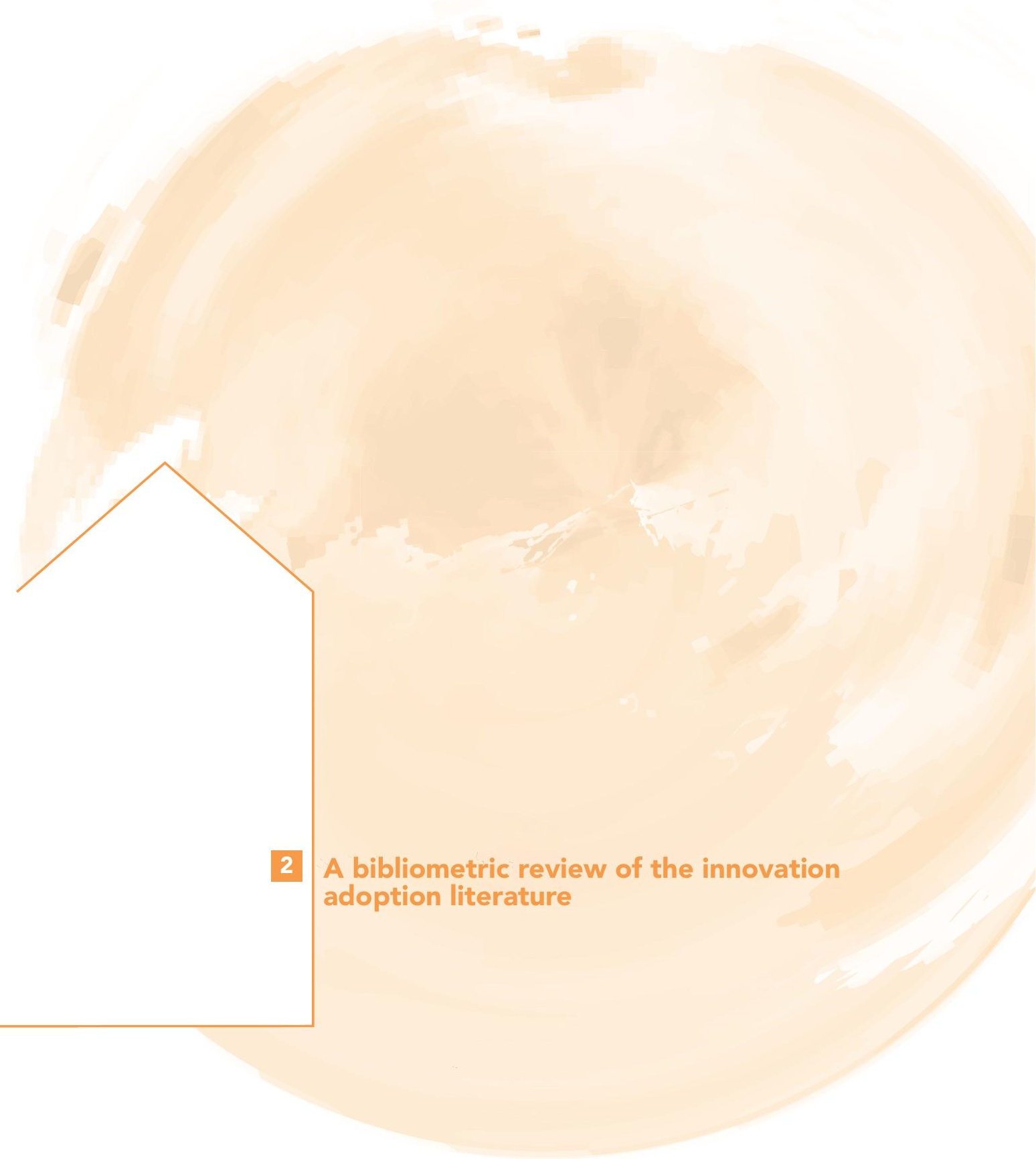




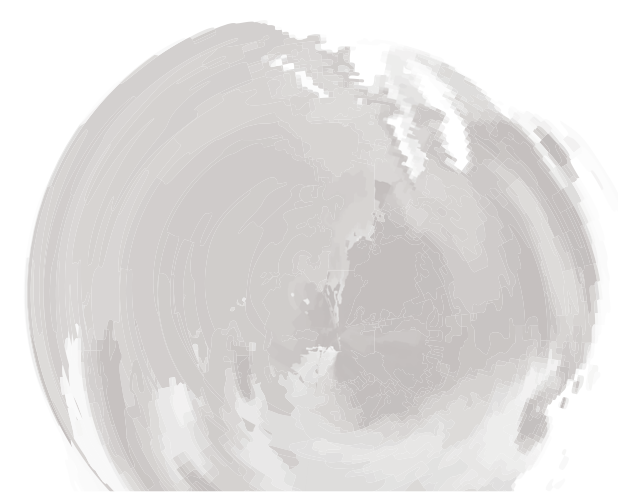

\section{A bibliometric review of the innovation adoption literature}

This chapter has been published in Technological Forecasting and Social Change ${ }^{10}$

\section{Abstract}

Innovation adoption is of utmost importance for company survival. That is why it is important to develop a thorough understanding of this research domain and the themes it encapsulates. Since the early work of Everett Rogers, the adoption of innovation literature has attracted considerable attention and has continued to grow rapidly, resulting in a large but fragmented body of literature. The goal of this study is to provide a coherent overview of the theoretical cornerstones as well as recent research trends in the innovation adoption literature. To this end, we conducted a bibliometric review and performed bibliographic coupling and co-citation analysis. First, based on co-citation analysis, we illustrate that innovation adoption research is built on four theoretical cornerstones including: institutional theory; theory of reasoned action; theory concerning the determinants of adoption, and; diffusion theory. Second, bibliographic coupling was used to assess the current research trends. This review is the first to identify thematic areas in an exhaustive manner revealing five clusters of thematic related publications or "research trends": determinants of IT adoption; adoption of technological standards; organizational rationales associated with adoption; modelling diffusion, and; adoption of agricultural innovations. We conclude this review with the limitations and future research orientations in the field of innovation adoption.

10.Van Oorschot, J.A.W.H., Hofman, E., \& Halman, J.I.M. (2018). A bibliometric review of the innovation adoption literature. Technological' Forecasting and Social' Change, 134, 1-21. The dataset necessary to reproduce the reported results is available at https://doi.org/10.1016/j.techfore.2018.04.032. 


\subsection{Introduction}

Many scientific publications in the field of innovation research start from the premise that innovation contributes to a firm's competitive advantage and is considered a necessity for firm survival.

Adoption-diffusion literature can be traced to the work of Gabriel Tarde, a French sociologist, who introduced the Laws of Imitation at the beginning of the 1900s (Tarde, 1903). However, not until Everett Rogers (1962) introduced the Diffusion of Innovations Theory (DOI) did adoption and diffusion research gain widespread recognition. Rogers conceptualized innovation adoption as a communication process whereby adoption reflects a pattern of information flow about an innovation. We start from the semantic work of Rogers (2003) to assess the innovation adoption literature.

A number of arguments speak for the theoretical and practical relevance of producing a review on the adoption of innovation. First, the innovation adoption literature has continued to grow rapidly since these early works which resulted in a large but also fragmented body of literature (Fagerberg and Verspagen, 2007; Gupta et al., 2007; Keupp et al., 2012). Second, as have been addressed by Gupta et al. (2007) and Keupp et al. (2012), innovation literature is organised in specific domains. While adoption research entered a wide variety of sectors within the economy (Rogers, 2003), the understanding of innovation adoption has grown considerably building on theoretical insights from innovation, organizational and behavioural centred theories. It has been suggested that a "schools of thought" approach might be a prominent path bringing together existing knowledge and theories (Furrer et al., 2008). Third, as have been emphasized in previous reviews (Keupp et al., 2012; Tidd, 2001), innovation research in the past decades has failed to deliver clear and consistent findings, coherent advice to managers, and convincing "best practice" solutions so far.

The aim of this article is to present a bibliometric review of the innovation adoption literature. In particular, we aim to 1) identify the theoretical foundations of innovation adoption, 2) pinpoint current themes in adoption of innovation research, and 3) identify avenues for future research. By helping innovation adoption scholars to understand better the key cornerstones of this field of research, the direction in which it is developing and by pointing to potential research gaps, our study is intended to provide a guideline for scholars in positioning their future research efforts. Therefore, we focused on two questions. First, what are the key theoretical cornerstones of innovation adoption research? Second, what are the current research trends within the field of innovation adoption?

The first research question involves a classification of scientific articles which revealed four theoretical cornerstones including: A) Institutional Theory and the legitimization of innovative behaviour; B) Theory of Reasoned Action and the Technology Acceptance Model; C) The determinants of innovation adoption through an econometric perspective; and D) Diffusion Theory. 
For the second research question we assessed the same cited references and identified five trending research directions including: 1) Drivers and impediments of information technology adoption; 2) The adoption of technology standards; 3) Organizational rationales associated with innovation adoption; 4) Modelling the diffusion process; and 5) Adoption of agricultural innovations.

The most recent influential innovation adoption review dates from 2004 conducted by Greenhalgh et al. (Greenhalgh et al., 2004). Since then, novel bibliometric methods have been developed to review the literature. Bibliometric studies have already shown their usefulness in a broad array of management research, including innovation (Kovacs et al., 2015; Marzi et al., 2017). Bibliometric reviews differ from highly cited reviews in this field (Feder et al., 1985; Geroski, 2000; Legris et al., 2003; Tornatzky and Klein, 1982; Van Eck and Waltman, 2010), on the aspects data, analysis and coverage (Furrer et al., 2008). A key benefit of bibliometric methods is their ability to help reduce reviewers' subjectivity and bias, which are inherent to conventional qualitative reviews (Vogel and Güttel, 2013). In contrast to respected and highly cited reviews in the field, our bibliographic study of the innovation adoption field is based on quantitative data rather than qualitative interpretations which tend to reflect the subjective views of the authors (Furrer et al., 2008; Marzi et al., 2017; Van Eck and Waltman, 2010). This article presents a bibliometric review of the innovation adoption research over the period 2003-2016.

In combining two techniques, co-citation analysis and bibliographic coupling, we visualize the network of publications on innovation adoption and arrive at distinct clusters of thematically related publications. This quantitative review allowed us to create a more systematic and encompassing picture of the adoption innovation research agenda, especially in terms of theoretical foundations and avenues for future research.

This chapter is structured in the following way. In the section that follows, Section 2.2, we discuss the method we applied to this review and present the articles included. In Section 2.3, the theoretical cornerstones of innovation adoption research are discussed; in Section 2.4, we consider recent debates on innovation adoption research. Section 2.5 discusses the key findings of this review and elaborates about the potential paths for future research. 


\subsubsection{Data}

For our two bibliometric analyses, we follow the four-step procedure as outlined by Kovacs et al. (2015). First, we developed a search query for the Web of Science (WoS) database (-Core Collection). We included articles using the terms: "innovation [and] adoption". We restricted our search to articles published between 2003 and 2016. We chose this time span because our preliminary analysis of the available review articles and meta-analysis studies indicated that the most influential literature reviews were at least three years old (see Table 2.1). A preliminary search resulted in the identification of approximately 6,800 articles. To further narrow down our search, only articles from the WoS Research Area "Business Economics" were included in the review, since our primary interest is in the mechanisms that affect innovation adoption from an innovation economics viewpoint. In-depth analysis of this refinement revealed that top innovation journals and the most cited articles were not excluded from the review (see Figure 2.1). Moreover, many of the articles that were excluded by this refinement addressed the status quo of a certain kind of "development" - describing them as innovative is questionable - without contributing to the development of innovation adoption theory itself. As a result, application of these selection criteria resulted in 3,713 articles that could be reviewed in greater depth.

Second, to ensure that each article in this study was relevant to the adoption-innovation domain, the abstract, key words, and introductory section were manually evaluated by the authors. This allowed us to exclude false positives, i.e. articles that include the terms "innovation" and "adoption" in the title, abstract, or keywords but are unrelated to the domain under study (see, for example, Keizer and Halman (2009)). We did not remove articles that were indirectly related to the innovation adoption debate, e.g. articles that focus on implementation and assimilation of innovations. These articles could well enrich the review and in case they are irrelevant to the domain under study they appear in the periphery of the visual map created with the Vos Viewer software. Applying the aforementioned selection criteria resulted in a set of 1,260 articles (with 45,932 references) to be included in the bibliometric review. For each of the 1,260 articles, an output file (tab-delimited) was generated from the WoS database. The cited references are relevant for this bibliographic review and formed the raw input for the VOS Viewer software.

Third, we analysed the WoS data of the remaining 1,260 articles using the VOS Viewer software. Two types of output were generated: a co-citation analysis of cited references and bibliographic coupling of the 1,260 articles identified. The VOS Viewer identified 1,260 articles suitable for bibliographic coupling, that together have 45,932 cited references of which 155 have a minimum of 20 citations. Figure 2.1 and Figure 2.2 present descriptive statistics of this dataset. 
During the fourth and final step, we interpreted the results of the co-citation analyses and the bibliometric coupling. To interpret and label the theoretical orientations of each cluster, all articles were downloaded from the Web of Science database and all books were accessed via the university library. The co-citation analysis of cited references was used to derive the theoretical cornerstones of innovation adoption research (Clusters A, B,C, and D). The output of the bibliographic coupling analysis allowed us to define the thematic clusters (Clusters 1, 2, 3, 4 and 5). Clusters A-D encompass a limited number of articles; therefore, the assessment of these clusters was relatively straightforward. However, each cluster, 1 to 5, holds up to 300 articles, making interpretation and labelling a less straightforward process. Therefore, for each cluster, the fifteen most cited articles were identified. However, since these articles could be situated on the periphery of a specific cluster, the 15 articles that are most closely related to each other were identified based on a cluster's density plot. The density view corresponds with the label view (Figure 2.6) with the difference that the labels are now expressed by a colour scheme. The colour scheme (blue-green-red) depends on the density of items at that point, i.e. the colour at a certain point is calculated by the number of items in the vicinity of that point as well as on the importance of the neighbouring items (Van Eck and Waltman, 2010). The authors independently labelled the clusters after which the results were discussed to find an agreed label for each cluster. The theoretical cornerstones and current research trends identified will be discussed in Sections 3 and 4 respectively.

The validity of any bibliometric review depends in part on the selection of publications that form the input of the analyses. Although the journals included in WoS Core Collection meet the highest standards regarding impact factor and number of citations (Falagas et al., 2008; Marzi et al., 2017), we decided to further evaluate the robustness of our bibliometric review by using the Scopus database. This allowed us to verify if we omitted relevant studies that could have affected our core findings ${ }^{11}$. Our search queries in the WoS and Scopus database resulted in 2,216 and 2,706 articles respectively. This difference is in part explained by a difference in the search queries used. In WoS the query was limited to the research area of 'business economics'. In Scopus this filter is not available and therefore we included articles linked to the two Scopus categories 'business management' and 'economics'.

By comparing the search results we observe that 1,088 articles are included in both output files, i.e. a $49 \%$ and $40 \%$ overlap with the WoS and Scopus data set respectively. As a next step we ran a separate co-citation analysis using the Scopus output file with VOS Viewer software. Examination of the two bibliometric maps revealed that both maps can be linked to the same theoretical cornerstones. From this we conclude that our findings are robust and not specific to the WoS database.

\footnotetext{
11. The EBSCO Academic Search Complete database deemed not suitable for this purpose as it excludes relevant innovation journals and includes grey literature that we did not want include in our analyses. Furthermore this database did not permit us to limit our search query to our focus area of 'business economics'.
} 
Table 2.1: Most cited review, overview and meta-analysis articles on adoption of innovation (based on the Web of Science citations linked to Google Scholar search results)

\begin{tabular}{|c|c|c|c|c|c|}
\hline $\mathrm{Nr}$ & Authors & Title & Citations & Type & Field \\
\hline 1 & $\begin{array}{l}\text { Venkatesh et al. } \\
\text { (2003) }\end{array}$ & $\begin{array}{l}\text { User acceptance of information technology: } \\
\text { Toward a unified view }\end{array}$ & 3,925 & Survey & ICT innovation \\
\hline 2 & Damanpour (1991) & $\begin{array}{l}\text { Organizational innovation - } \\
\text { A meta-analysis of effects of determinants } \\
\text { and moderators }\end{array}$ & 1,706 & $\begin{array}{l}\text { Meta- } \\
\text { analysis }\end{array}$ & $\begin{array}{l}\text { Organizational } \\
\text { innovation }\end{array}$ \\
\hline 3 & $\begin{array}{l}\text { Greenhalgh et al. } \\
\text { (2004) }\end{array}$ & $\begin{array}{l}\text { Diffusion of innovation in service } \\
\text { organizations: Systematic review and } \\
\text { ecommendations }\end{array}$ & 1,724 & Review & $\begin{array}{l}\text { Health care } \\
\text { innovation }\end{array}$ \\
\hline 4 & Legris et al. (2003) & $\begin{array}{l}\text { Why do people use information } \\
\text { technology? A critical review of the } \\
\text { technology acceptance model }\end{array}$ & 713 & Review & ICT innovation \\
\hline 5 & $\begin{array}{l}\text { Tornatzky and } \\
\text { Klein (1982) }\end{array}$ & $\begin{array}{l}\text { Innovation characteristics and innovation } \\
\text { adoption-implementation - a meta-analysis } \\
\text { of findings }\end{array}$ & 709 & $\begin{array}{l}\text { Meta- } \\
\text { analysis }\end{array}$ & $\begin{array}{l}\text { Not sector } \\
\text { specific }\end{array}$ \\
\hline 6 & Feder et al. (1985) & $\begin{array}{l}\text { Adoption of agricultural innovations in } \\
\text { developing countries }\end{array}$ & 604 & Survey & $\begin{array}{l}\text { Agricultural } \\
\text { innovation }\end{array}$ \\
\hline 7 & Geroski (2000) & Models of technology diffusion & 386 & Survey & $\begin{array}{l}\text { Not sector } \\
\text { specific }\end{array}$ \\
\hline 8 & $\begin{array}{l}\text { Gatignon and } \\
\text { Robertson (1985) }\end{array}$ & $\begin{array}{l}\text { A propositional inventory for new } \\
\text { diffusion research }\end{array}$ & 360 & Review & $\begin{array}{l}\text { Not sector } \\
\text { specific }\end{array}$ \\
\hline 9 & Wolfe (1994) & $\begin{array}{l}\text { Organizational innovation - review, } \\
\text { critique and suggested research directions }\end{array}$ & 343 & Review & $\begin{array}{l}\text { Organizational } \\
\text { innovation }\end{array}$ \\
\hline 10 & $\begin{array}{l}\text { Frambach and } \\
\text { Schillewaert (2002) }\end{array}$ & $\begin{array}{l}\text { Organizational innovation adoption-- } \\
\text { a multi-level framework of determinants } \\
\text { and opportunities for future research }\end{array}$ & 247 & Review & $\begin{array}{l}\text { Organizational } \\
\text { innovation }\end{array}$ \\
\hline
\end{tabular}

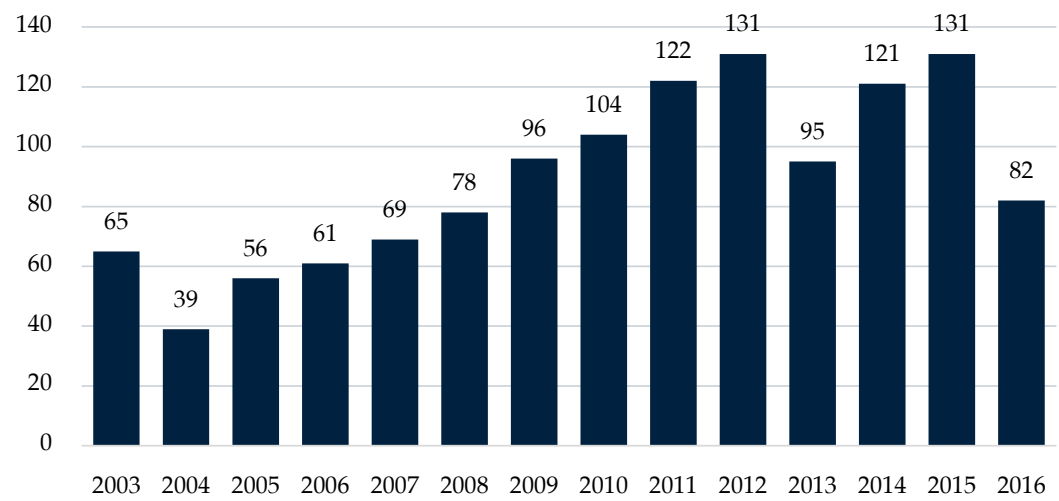

Figure 2.1: The number of scientific articles about innovation adoption per year included in this review 


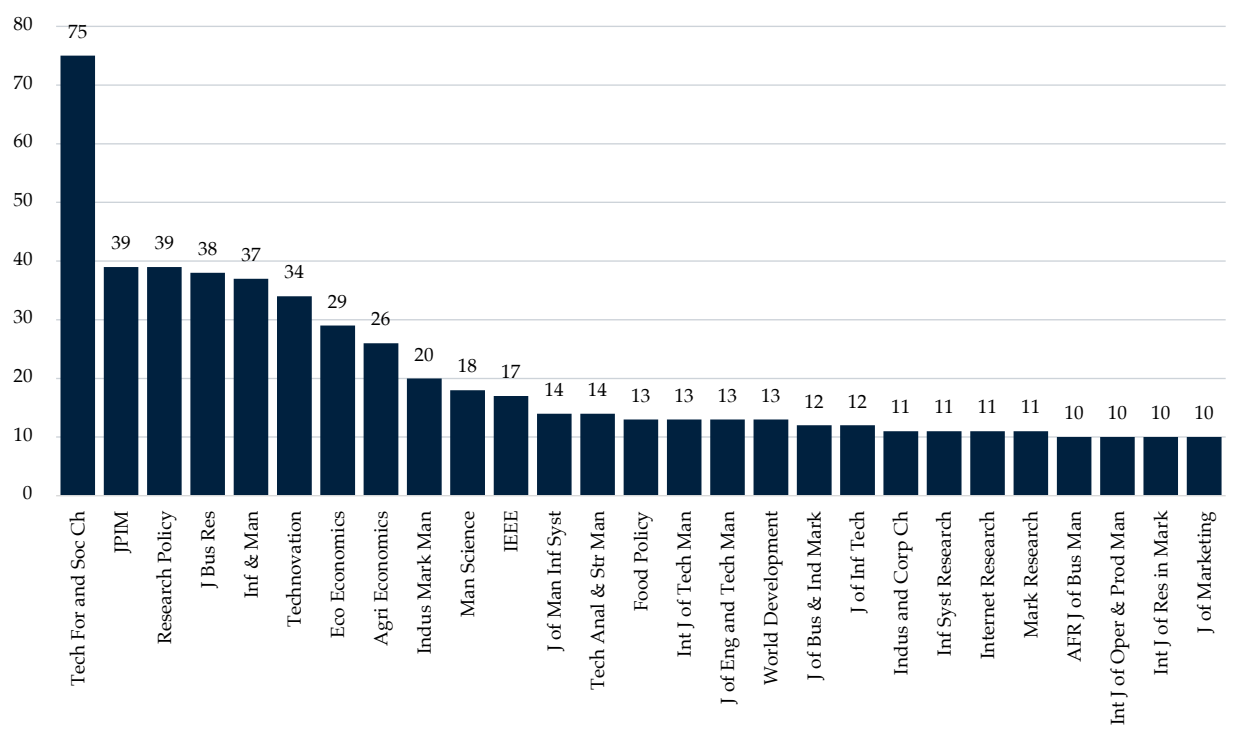

Figure 2.2: Number of scientific articles about innovation adoption per year per academic journal (560 articles (out of 1260), or 44\%, have been published in 27 scientific journals).

\subsubsection{Methods: Bibliographic coupling and co-citation analysis}

Many methodological scholars have emphasized the need for a process of systematic reviewing in order to overcome the bias challenge facing scientific literature reviews. The principles of "systematic reviewing" are based on a replicable, scientific and transparent protocol. Such protocols minimize human error and bias in mapping and synthesizing the fragmented empirical studies (Cook et al., 1997; Tranfield et al., 2003). To further reduce the reviewer bias, it would be possible to perform a bibliometric analysis that does not depend on the reviewer's knowledge or preferences (Bricker, 1989). In order to identify thematic similarities between articles published in scientific journals on innovation adoption, we rely on two bibliometric analysis techniques based on the overlap between reference patterns: (1) bibliographic coupling and (2) co-citation analysis.

Bibliographic coupling clusters recent articles but fewer old articles: co-citation clustering does the opposite, being unable to cluster the most recent articles that have not yet been cited (Boyack and Klavans, 2010). Clusters identified by co-citation analysis form the cornerstones of the research front in the literature on innovation adoption while bibliographic coupling helps to identify clusters representing the more recent research themes that do not necessarily match the cornerstones. The methods differ from each other in the direction of referencing: this is visualised in Figure 2.3 and Figure 2.4 (adapted from Boyack and Klavans (2010)). The grey box in Figure 2.3 and Figure 2.4 represents the longitudinal dataset of innovation adoption articles that are included in the review. Articles $\mathrm{A}, \mathrm{B}, \mathrm{C}, \mathrm{D}$ and $\mathrm{E}$ represent the most recent published articles, and papers $\mathrm{M}, \mathrm{N}, \mathrm{O}$ and $\mathrm{P}$ 
are somewhat older, dating from 2003. Articles W, X, Y and Z were published before 2003 and are not part of the longitudinal dataset but, as they are cited by publications in the longitudinal dataset, they are included as external references.

Co-citation analysis allows us to reveal the theoretical foundations of the research field by assessing the similarities among cited articles (Boyack and Klavans, 2010). Clusters A and B in Figure 2.3 are derived from the co-citation analysis and, as is evident, these clusters contain articles that are published prior to the articles included in the dataset.

Bibliographic coupling links documents that reference the same set of cited documents and is used to assess the similarity between citing articles (Boyack and Klavans, 2010). This is illustrated in Figure 2.4; Clusters 1 and 2 result from bibliographic coupling of the articles in the dataset. Note that the older articles in the innovation adoption dataset, represented by articles $\mathrm{M}, \mathrm{N}, \mathrm{O}$ and $\mathrm{P}$, could be included in a co-citation cluster as well as a cluster identified by bibliographic coupling.

Following Kovacs et al. (2015), we combine these complementary techniques to uncover both past research traditions and current trends in the field of innovation adoption. For a more detailed description of this approach, see Boyack and Klavans (2010) and Kovacs et al. (2015). In line with the work of Van Eck and Waltman (2010), this review applies their association strength measure to reveal the clustering of innovation adoption articles, i.e. it determines the normalized strength between related papers based on similarities among their reference lists (p531):

$$
S_{i j}=\frac{C_{j}}{W_{i} W_{j}}
$$

$C_{i j}=\quad$ Number of citations (received by) or references (referred to) that articles $i$ and $j$ have in common; $W_{i}=$ Total number of citations or references article $i ; W_{j}=$ Total number of citations or references article $j$.

The relative distance (the higher the values of $S_{\text {ij }}$ ) between the focal articles $A$ and $B$ based on the reference list depends on the quotient between overlapping references and the number of references that could have been made by both publications. This calculation is made for every pair of publications included in the review, one time based on bibliographic coupling and the other time based on co-citation. We used the Visualization of Similarities (VOS) approach (http://www.vosviewer.com) to identify and visualize thematic clusters based on the relatedness between our set of publications (Van Eck and Waltman, 2010). VOS software combines optimization and clustering algorithms to visualize the relative distance, which reflect the level of similarity between reference lists, and between articles included in the analysis. For the mathematical details, we refer to Van Eck and Waltman (2010). The software places the most connected articles in the middle of the two-dimensional space and, thus, the least connected articles are printed at relative distance from the centre. 
Next, articles are presented in clusters based on Newman and Givan's modularity function (2004), where the maximization of the modularity function is parameterized by a resolution parameter. In the VOS Viewer, this parameter can be adjusted to alter the (optimal) number of clusters derived. This parameter is particularly useful in identifying small clusters - a weakness of modularity-based clustering techniques. In our study we slightly adjusted the resolution parameter, set at 0.75 in contrast to the default setting of 1.0 , which resulted in a clearer distinction between cluster, all other settings were set to default. In Figure 2.5 the size of the title of individual publications and the size of the corresponding circle indicate the importance of the publication within the map, depending on the number of neighbouring articles, the distance between these articles and the number of citations these articles received. The distance between two articles explains the overlap between them, i.e. the closer two articles are positioned to each other the more the overlap between the work cited by these publications. Items positioned at a larger distance are less often cited together. Based on the proximity between all publications, clusters are formed which are highlighted with different colours in the map. As explained earlier, to facilitate interpretation of each cluster we also gave a unique label to each cluster that best matches the content of each cluster of publications. Clusters located next to each other indicate closely related fields. Visa versa, clusters at a relative distance cover more different research fields (Van Eck and Waltman, 2010).

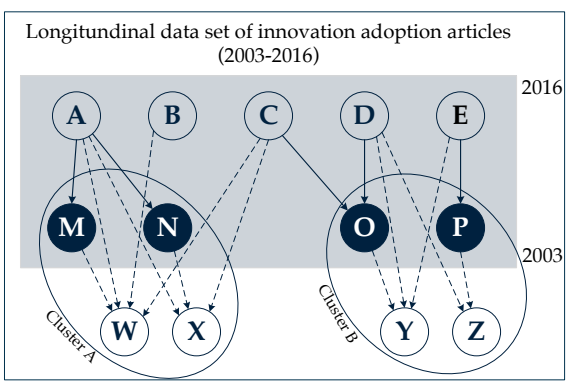

Figure 2.3: Illustration of co-citation analysis (adapted from Boyack and Klavans (2010)).

The grey box represents the longitudinal dataset of innovation adoption papers included in the review. Articles A-E represent the most recent published articles and papers. M-P are somewhat older going back to 2003. Articles W-Z were published before 2003 and were not included in the review. Clusters A and B result from the formation of co-cited articles and, thus, these clusters contain articles that were published before the articles in the dataset. Clusters A and B are referred to as the theoretical cornerstones of innovation adoption research.

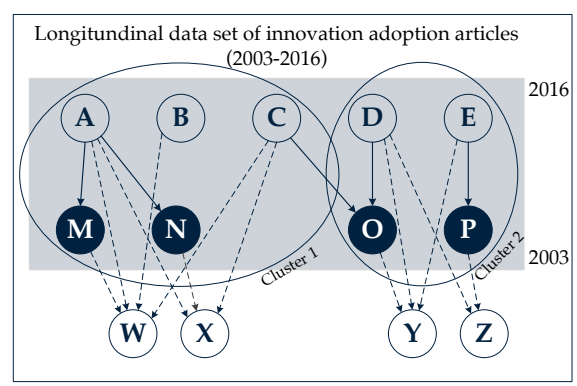

Figure 2.4: Illustration of bibliographic coupling (adapted from Boyack and Klavans (2010)).

The grey box represents the longitudinal dataset of innovation adoption papers included in the review. Articles A, B, C, D and E represent the most recent published articles, and papers $\mathrm{M}, \mathrm{N}, \mathrm{O}$ and $\mathrm{P}$ are somewhat older, going back to 2003. Articles W-Z were published before 2003 and were not included in the review. Clusters 1 and 2 result from bibliographic coupling of the articles in the dataset based on the links between the articles that reference the same set of cited articles. 


\subsection{Cornerstones of innovation adoption research}

Figure 2.5 shows the bibliographic network based on co-citation analysis and reveals the theoretical cornerstones of innovation adoption research. Figure 2.5 displays a relatively coherent network in which clusters A, B, C and D are tied together by different editions of Rogers' seminal work positioned in the core of the network (Rogers, 1962, 1983, 1995, 2003). We included externally cited references in the analysis (Boyack and Klavans, 2010). Taking into account the different citation styles of journals, this resulted in the identification of 45,932 unique references. To facilitate interpretation of the clusters, we restricted our focus to references that were cited 20 times or more. This helped us to focus on the most important publications and facilitated interpretation of the identified clusters in the network. Our network of publications, shown in Figure 2.5, consists of four clusters. Each cluster consists of vertices that represent the cited references. Publications represented by larger vertices are cited more often by the publications in our longitudinal dataset than those that are represented by smaller vertices. The distance between vertices corresponds to the likelihood of co-citation, i.e. the closer two vertices are located together in the network, the more likely these references will be cited together. In this respect, publications in a cluster are more likely to be cited together than any combination of publications from separate clusters.

It should be noted that the four clusters are tied together by four (out of five) editions of Everett Rogers' Diffusion of Innovations (1962, 1983, 1995, 2003). As the latest version of Rogers' book, Diffusion of Innovations (2003), has been used for the development of the search query "innovation adoption", it will not be considered in detail in order to derive a meaningful and distinctive description of each cluster. For the same reason, methodological publications are not considered any further. The relatively empty centre of the structure indicates that clusters are clearly separated from each other (Van Eck and Waltman, 2010, p.535). A more detailed analysis in Figure 2.5 indicates that Clusters A and C are relatively coherent where "gaps" or relative empty spaces can be found between publications in Clusters B and D. Following the protocol discussed in Section 2.1, the following clusters have been identified: A) Institutional Theory and the legitimization of innovative behaviour; B) Theory of Reasoned Action and the Technology Acceptance Model; C) The determinants of innovation adoption, an econometric perspective; and D) Diffusion Theory. In the following sections, 3.1 to 3.4, we assess the theoretical cornerstones of innovation adoption research, i.e. we define each of the four identified clusters and assess the relative importance of the clusters. 


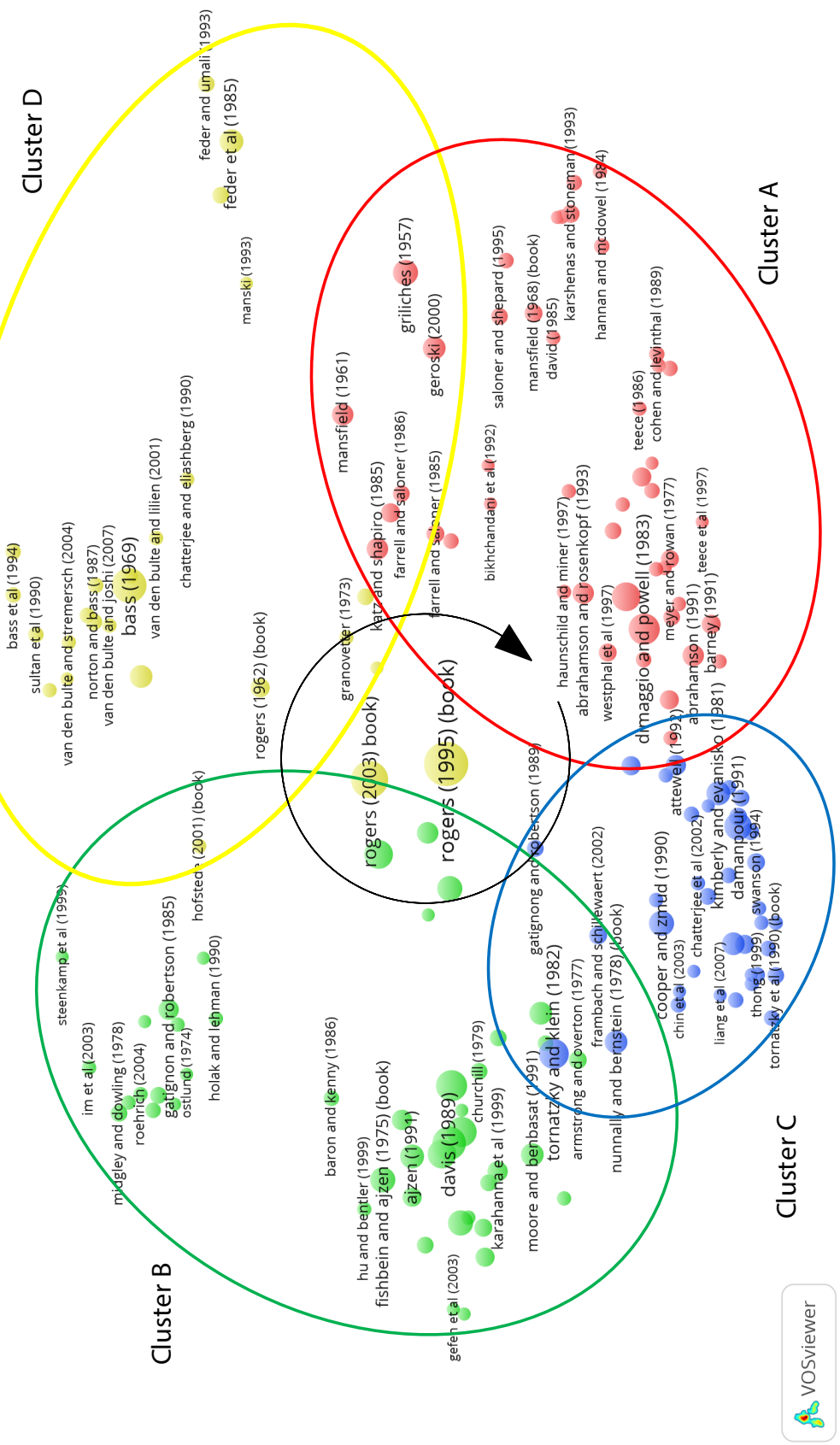

Figure 2.5: Co-citation network of references cited by innovation adoption publications between 2003 and 2016. The research fields, or theoretical cornerstones, are linked to each other by the seminal work of Rogers on which we base our search query. 


\subsubsection{Cluster A: Institutional Theory and the legitimization of innovative behaviour}

Cluster A, which includes 37 articles and 7 book publications, can be labelled as "Institutional Theory and the legitimization of innovative behaviour". In common, the publications in this cluster address forces that dictate how firms behave, how they innovate and which innovations they adopt. One of the most important explanations can be found in Institutional Theory. Next, four themes related to firm behaviour with respect to innovation and innovation adoption and diffusion were identified in the periphery of Cluster A. Finally, three methodological publications were dropped while they do not address innovation adoption or diffusion. Table 2.2 provides an overview of the 44 publications, their theoretical contribution and the implications for innovation adoption-diffusion research. Table 2.2 makes clear that most of the publications included in Cluster A address firm behaviour at the aggregate level and do not address innovation adoption in particular. Moreover, the few publications which address adoption and/or diffusion are found in the periphery of Cluster A. Therefore, we have organized the publications according to the theoretical concept upon which they build and have deduced the conceptual adoption mechanism from them as shown in the last column. To grasp this cluster, we drew on the work of Agrote and Greve (2007).

In the main, Cluster A encompasses the theoretical background from which scholars derived their conceptualizations in order to explain innovative behaviour and, thus, innovation adoption (as is evident in Section 4). In this respect, Cluster A is considered better "grounded in theory" than the clusters discussed in the next sections. In particular, institutional theory is well covered (Table 2.2). Conceptualizations based on institutional theory build upon the notion that the acceptance of any innovation, or any other form of change challenging an incumbent institution, depends, by and large, on its (regulative, normative and cultural-cognitive) legitimacy. In this regard, it opposes the socio-economic efficiency considerations addressed in Cluster C (Abrahamson, 1991).

Four themes related to firm innovative behaviour can be found in the periphery of Cluster A. Closely related to Cluster D, the first theme addresses adoption-diffusion from an econometric viewpoint. Before the well-known work of Rogers (1962) and Bass (1969), Griliches $(1957)$ and Mansfield $(1961 ; 1968)$ published about "the longer-run aspects [in the economics] of technology change" (Griliches, 1957, p521) and "technological change and the differences among innovations in the rate of imitation" (Mansfield 1961, p741). The work of Griliches (1957) presents a logistic growth function (S-curve) based on parameter origins (availability of a new technique), slopes (rate of acceptance) and ceilings (equilibrium level use). Mansfield (1961) introduced an imitation model based on the hypothesis that: "the probability that a firm will introduce a new technique is an increasing function of firms already using it and the profitability of doing so, but a decreasing function of the size of the investment require" (pp.762-763) $)^{12}$. Geroski (2000) studied several alternative technology diffusion models.

12.Rogers made the terms "adoption" and "diffusion" popular among scholars. However, the early work in this field dates back to Gabriel [de] Tarde who introduced the "Laws of Imitation" around 1900 and, therefore, these terms are used in early publications. 
In contrast to the dominant S-curve diffusion model or epidemic model, two alternative approaches are emphasized (probit models and models of density dependence).

Next, the second theme embodies the Network Externalities Theory, which studies the implications of network effects on innovation adoption-diffusion (Farrell and Saloner, 1985, 1986; Katz and Shapiro, 1985). "Direct network externalities" refers to the notion that the level of user value depends on the size of the installed base, i.e. the number of other adopters of the innovation. In contrast, indirect network externalities increase utility through the availability of complementarities; for example, the availability of DVDs (complementarities) increases the utility of DVD players (installed base).

A third topic addresses the relation between complementary organizational capabilities and innovation (Milgrom and Roberts, 1990a). In this respect, Cohen and Levinthal (1989, 1990) introduced the concept of Absorptive Capacity. Moreover, Teece et al. (1997) introduced the concept of Dynamic Capabilities. Dynamic Capabilities encompass specific capabilities and resources which constitute a firms' competitive advantage. This framework has been applied by scholars to assess how a set of competences and resources are developed, deployed, and protected by a specific firm within changing and competitive economic environments. In contrast to research projects that study the adoption of innovation in isolation, Bresnahan et al. (2002) analysed the effect of the complementary adoption of three related innovations. Finally, the publications which do assess the adoption and diffusion of innovation are found in the periphery of Cluster A. Jensen (1982) and Karshenas and Stoneman (1993) for example attempted to bridge the gap between the work of Griliches and Mansfield and the work of Rogers by addressing the gap between understanding adoption-diffusion behaviour at the aggregate industry level and individual firm's adoption behaviour taking into account both economic and information communication factors. Thus, these publications take into account market structure and organizational innovation behaviour (David, 1985; Fudenberg and Tirole, 1985; Hannan and McDowell, 1984; Milliman and Prince, 1989; Reinganum, 1981). 
Table 2.2: Overview of the 44 publications in Cluster A. The publications included address, how firms innovate, and which innovations they adopt from a behavioural point of view

\begin{tabular}{lll}
\hline Reference & Theory & Conceptual adoption mechanisms deduced from theory* \\
\hline (Cyert and March, 1963) & $\begin{array}{l}\text { Behavioural } \\
\text { Theory of the } \\
\text { Firm }\end{array}$ & $\begin{array}{l}\text { Adoption behaviour (the adoption of innovation) depends on } \\
\text { several mechanisms which related to: bounded rationality of } \\
\text { the firm; firm"s problematic search; the dominant coalition; } \\
\text { standard operating procedures within the firm, and firms } \\
\text { slack search - subsequently, these mechanisms can be found } \\
\text { in a number of related organizational theories. }\end{array}$
\end{tabular}

(Nelson et al., 1982); (Tushman and Anderson, 1986)

(Meyer and Rowan, 1977);

(Tolbert and Zucker, 1983);

(Dimaggio and Powell, 1983);

(Abrahamson, 1991); (Bikh-

chandani et al., 1992); (Abra-

hamson and Rosenkopf, 1993, 1997); (Suchman, 1995); (Westphal et al., 1997); (Haunschild and Miner, 1997); (Abrahamson and Fairchild, 1999);

(Cohen and Levinthal, 1989, 1990); (Milgrom and Roberts, 1990a); (Teece, 1986); (Teece et al., 1997); (Bresnahan et al., 2002)

(Schumpeter, 1934; Schumpeter, 1942); (Porter, 1980); (Henderson and Clark, 1990)

(Barney, 1991); (Pfeffer and Salancik, 1978)

(Farrell and Saloner, 1985, 1986); (Katz and Shapiro, 1985, 1986); (Saloner and Shepard, 1992)

(Griliches, 1957); (Mansfield, 1961; Mansfield, 1968); (Geroski, 2000)

(Reinganum, 1981); (Jensen, 1982); (Hannan and McDowell, 1984); (Fudenberg and Tirole, 1985); (Milliman and Prince, 1989); (Karshenas and Stoneman, 1993)

\section{Evolutionary Economic Theory}

Institutional Theory

Absorptive Capacity, dynamic capabilities and complementarities

Schumpeterian (economic) theory of

"creative destruction"

Resource-based view

Network externalities Theory

Diffusion econometrics

Market structure and organizational innovation adoption behaviour
Longitudinal perspective on technological change; technologies evolve through periods of incremental change punctuated by breakthroughs that affect firm (adoption) behaviour (prompted by uncertainty).

The acceptance of any innovation, or any other form of change challenging an incumbent institution, mainly depends on its (regulative, normative and cultural-cognitive) legitimacy (in contrast to economic efficiency considerations).

*conceptual because the mechanisms are relatively abstract compared to the mechanisms identified in Cluster 3 . 


\subsubsection{Cluster B: Theory of Reasoned Action and the Technological Acceptance Model}

Cluster B is labelled as: "Theory of Reasoned Action and the Technology Acceptance Model". Cluster B encompasses 30 publications, including 2 book publications, that can be subdivided into two groups of closely related publications, B1 and B2 respectively. About 11 methodological publications were dropped as were three versions of Rogers' Diffusion of Innovations book. Next, we discuss the two subsets in more detail.

The 16 articles of Subset B1 build upon the concept of technology acceptance. The Technology Acceptance Model is grounded in the Theory of Reasoned Action (TRA) developed by Fishbein and Ajzen (1975) from which, later on, the "(Decomposed) Theory of Planned Behavior" ((D)TPB) has been developed (Ajzen, 1991; Ajzen and Fishbein, 1980; Taylor and Todd, 1995). The TRA has been developed to predict and explain social behaviour in general. The Technology Acceptance Model (TAM) was introduced by Davis (1986) and was developed to specifically explain computer usage intention and actual usage behaviour. Later studies refined the original TAM (Davis, 1989; Davis et al., 1989; Venkatesh and Davis, 2000), which resulted in several versions of the model such as TAM2 (Venkatesh and Davis, 2000) and the Unified Theory of Acceptance and Use of Technology (UTAUT) (Venkatesh et al., 2003). The basic assumptions of TAM encompass the causal relation between Perceived Usefulness, Perceived Ease of Use, and the decision makers' attitudes, intentions and actual innovation usage. In general, this research stream demonstrates that the intention to use an innovation is the only accurate predictor of the actual adoption and use of the innovation (Chang and Cheung, 2001).

How are the innovation adoption-diffusion and the innovation acceptance line of debate positioned alongside each other? Four articles in this cluster focus on complementarities between both lines of debate (Agarwal and Prasad, 1997, 1998; Karahanna et al., 1999; Moore and Benbasat, 1991). Criticizing the adoption-diffusion theory, these scholars claim that the adopters' perception of the innovation does not itself explain its diffusion but rather their perception of applying the innovation. This critique has been stimulated by Rogers' definitions of the five perceived innovation characteristics (i.e. relative advantage, compatibility, complexity, observability and trialability) (Rogers, 2003). Addressing this critique, the innovation acceptance line of debate is based on the assumption that innovation behaviour (usage) is preceded by the intention to use the innovation. In contrast, the innovation acceptance line of debate has been criticized for its lack of a comprehensive set of attributes explaining technology acceptance outcomes as found in innovation adoption-diffusion research. As a result, several attempts have been made to include these attributes in the TAM (see Cluster 1, Section 4.1).

Fourteen articles form a subset in Cluster B, referred to as B2, although these articles are closely related to the technology acceptance line of debate (Dickerson and Gentry, 1983; Gatignon and Robertson, 1985; Midgley and Dowling, 1978). Their relative distance from the rest of the articles can be explained by the origins of these papers; the core publications 
were published just prior to the introduction of the concept of technology acceptance. The publications within subset B2 explore consumer innovativeness in more detail (Midgley and Dowling, 1978; Roehrich, 2004). The review of Roehrich (2004) revealed that the concept of innovativeness is still under debate and lacks clear conceptualizations and measures (even after decades of research since its introduction in the early seventies).

\subsubsection{Cluster C: Determinants of innovation adoption, an econometric perspective}

This cluster is labelled "The determinants of innovation adoption, an econometric perspective" and includes 35 publications. Cluster C encompasses subsequently 33 scientific papers and 2 book publications. Two publications were dropped as these references o0nly include research methodology issues. Compared to Clusters A, B and D, Cluster C is relatively coherent. As can be seen in Figure 2.5, Cluster C is enclosed by Clusters A and B and, therefore, publications assigned to Cluster $\mathrm{C}$ are often cited in combination with publications from these clusters in contrast to Cluster D. From the publications constituting Cluster $C$ it was derived that these publications apply a variance based approach as the dominant research strategy. More specifically, Cluster $C$ publications apply unidirectional causations to assess the impact of determinants on the adoption of specific innovations within various contexts (see Table 2.3).

The articles in this cluster all address the Downs and Mohr critique (1976) on the generalizability of research findings on innovation adoption. In their article, they argued that innovation adoption models lacked a rigorous theoretical foundation and were too simplistic since they failed to take into account contextual differences, i.e. contingency variables. Most of the publications in this cluster examine the contingencies influencing the adoption of different types of innovation in different contexts (Dewar and Dutton, 1986; Kimberly and Evanisko, 1981).

In contrast, Tornatzky and Klein's (1982) meta-analysis addresses the question of whether "across an heterogeneous array of innovations, actors, and organizations, the innovation characteristic-adoption relationship vary widely or reverse itself" (p.29). These scholars oppose, to some degree, the argument in Downs and Mohr's critique. Instead, Tornatzky and Klein propose that "perceived innovation characteristics can predict the adoption and implementation of various innovations, and with some degree of consistence across various settings. [They] assume that the literature fails, to a considerable extent, to exploit this possibility because of methodological and conceptual problems in many of the innovation characteristic studies"(p.29). Meyer and Goes (1988) and Cooper and Zmud (1990) also presented several methodological and conceptual shortcomings regarding adoption research. 
Furthermore, Damanpour (1991) has levelled the criticism that researchers have overemphasized sub-theories of organizational innovation adoption. According to Damanpour, the purpose of those studies, such as Kimberly and Evanisko (1981) and Dewar and Dutton (1986), was to further explore several specific dimensions of innovation and their determinants. However, the sub-theories have not been evaluated in different contexts (p.556). In contrast, several researchers claim that an unified adoption theory does not exist at all because the variations in innovations and the adoption context in which the innovations will be applied are unique, and that the contingencies of every situation must be taken into account (Fichman and Kemerer, 1993; Thong, 1999). A recent meta-analysis conducted by Jeyaraj et al. (2006) shed some new light on this debate. These authors assessed the determinants which affect IT adoption at the individual and organizational level. They found that, at the aggregate level, innovation and organizational determinants are both predictors of individual and organizational adoption. These scholars conclude that both categories of determinants are strong predictors of IT adoption at the individual and organizational level.

Taken together, this cluster addresses the different conceptualizations of the adoption of distinct innovations affected by a specific set of contingency variables. The two most frequently applied frameworks to study innovation adoption in its context, including innovation, organizational and contextual determinants, have been developed by Tornatzky et al. (1990) and Iacovou et al. (1995). Moreover, Cluster C can be considered as the birthplace of middle-range theories of adoption. 

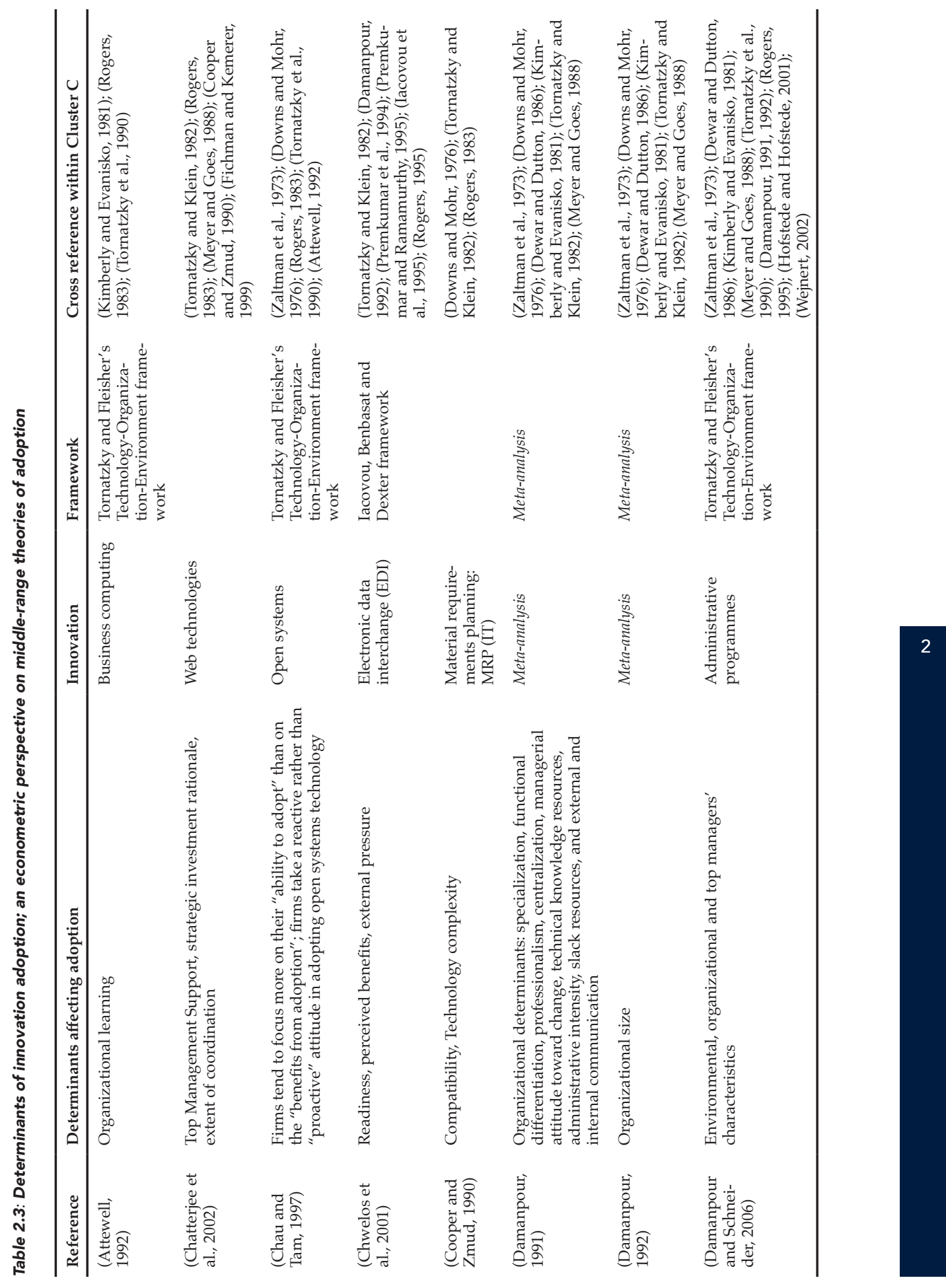


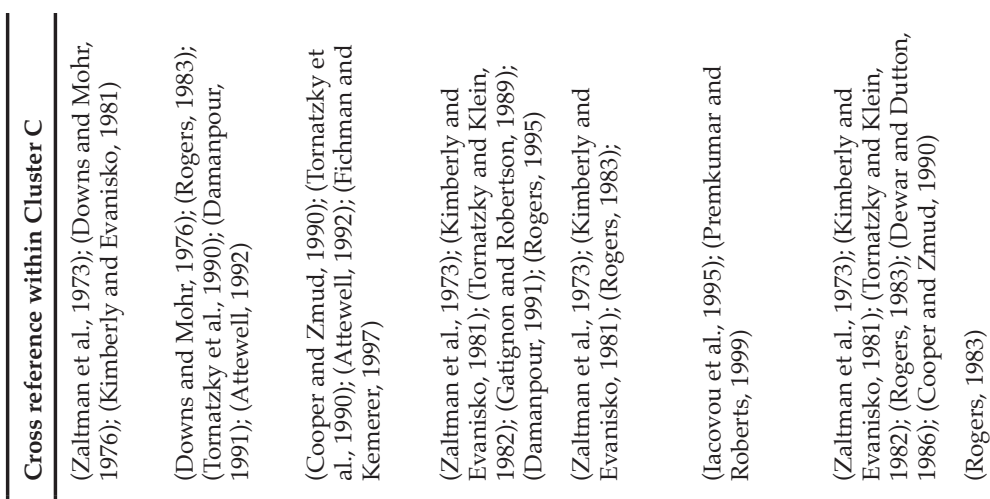

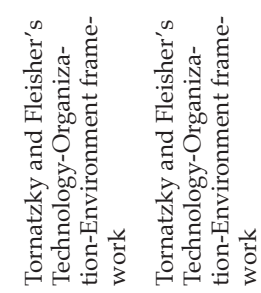

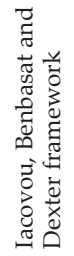
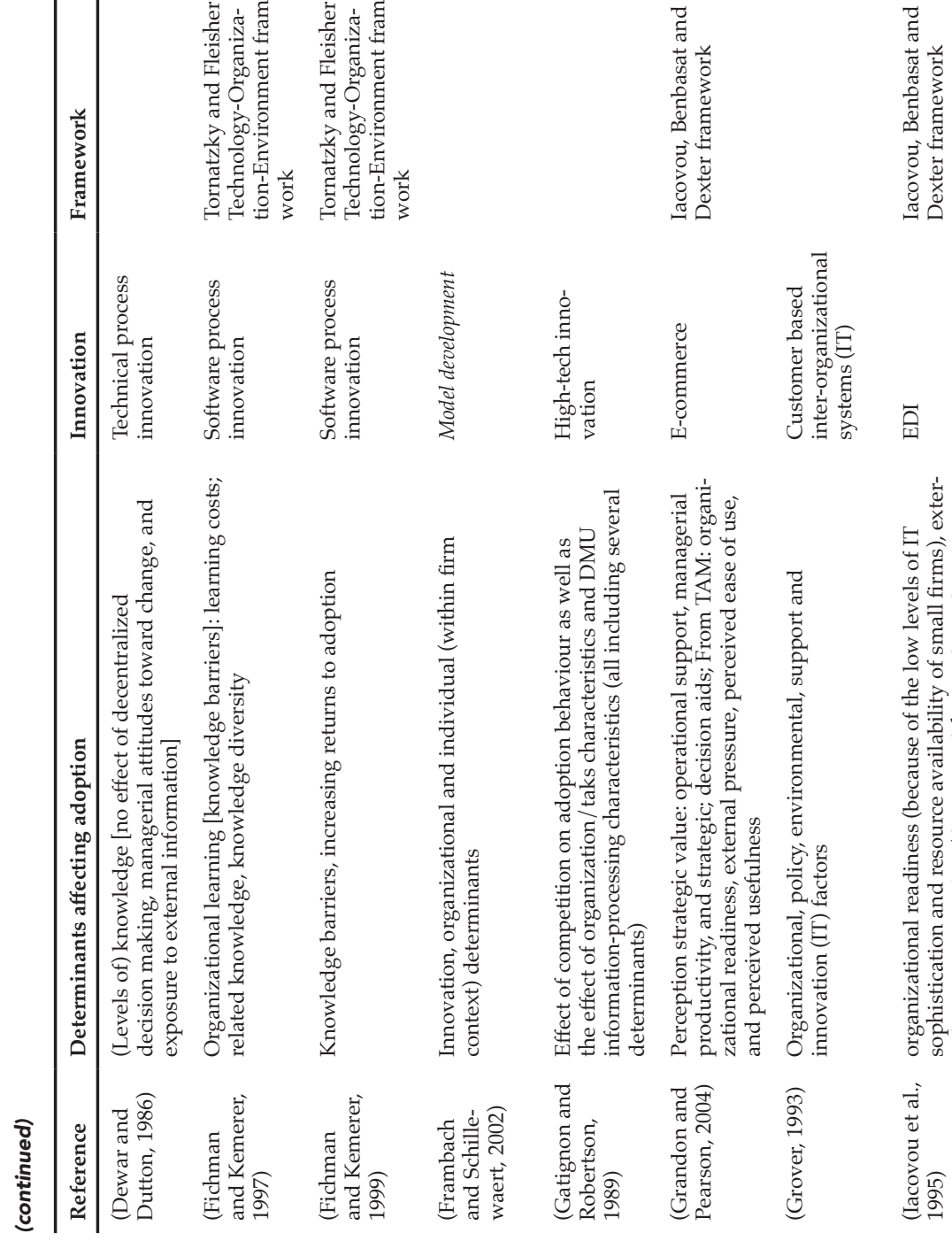

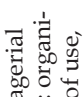

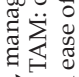

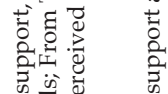

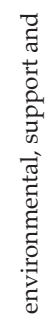

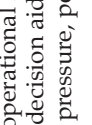

다.

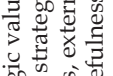

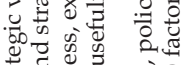

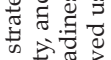

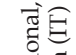

它完

롤

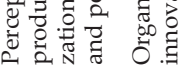

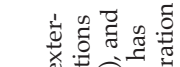

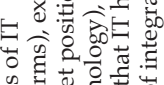
o 흘

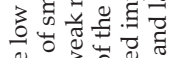

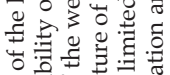

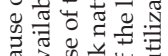
要

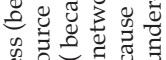

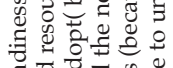

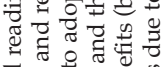

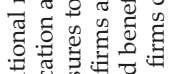

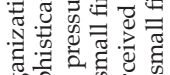

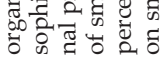

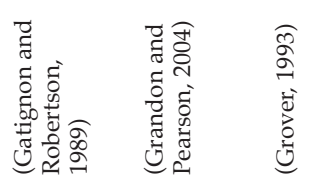
| 

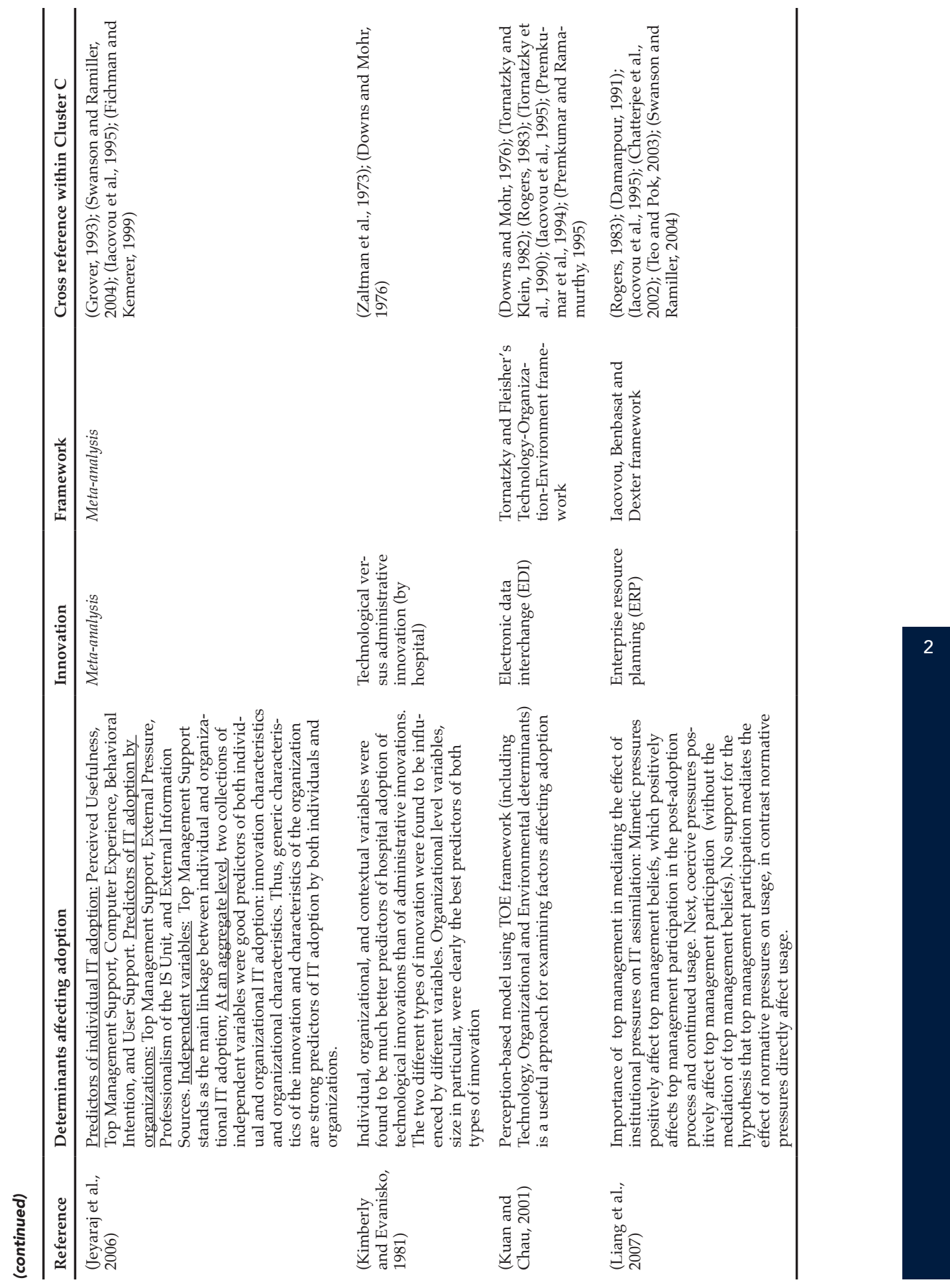


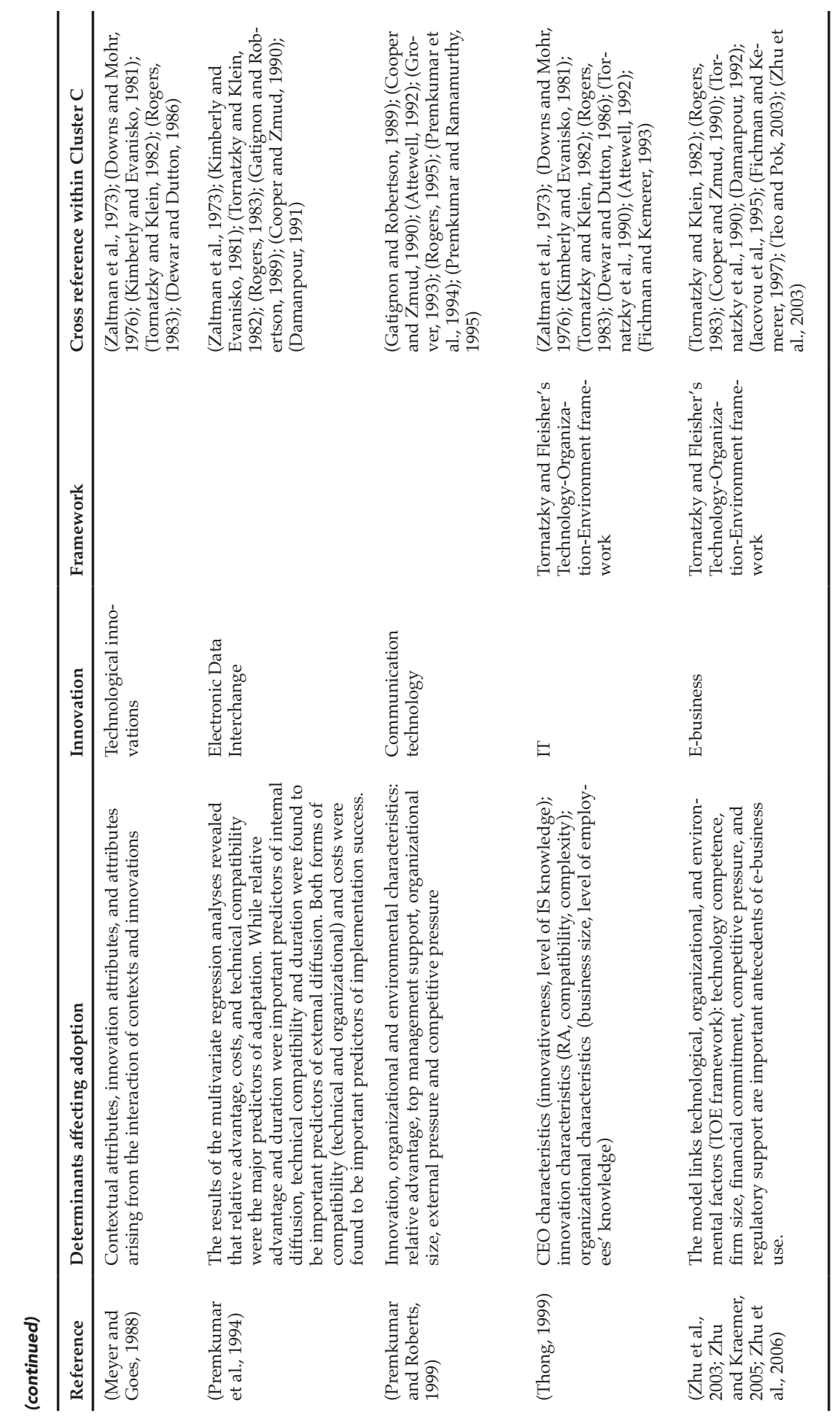




\subsubsection{Cluster D: Diffusion Theory}

Cluster D is labelled as "Diffusion Theory" since most references in this cluster focus on the mathematical modelling of diffusion processes. Cluster D encompasses 23 publications, including 2 book publications, and mainly includes elaborations on the modelling of diffusion processes building upon the Bass model. Similar to Cluster B, three publications of Rogers' Diffusion of Innovation were excluded. Next, a small subset within Cluster D specifically focuses on the diffusion of agricultural innovations, the effect of policy intervention on diffusion, and the effect of diffusion on economic development.

Most of the articles in Cluster D can be related to the work of Frank M. Bass, after which the Bass Model has been named (Bass, 1969; Mahajan et al., 1990; Norton and Bass, 1987). This research is closely related to early work of Griliches (1957) and Mansfield (1961) which can be found in Cluster A. Bass devised his model in 1969 in order to develop a theory of timing concerning the initial purchase of new consumer products. The Bass model is based on the assumption that "the probability of purchase at any time is related linearly to the number of previous buyers. [..] The model implies exponential growth of initial purchases to a peak and then exponential decay" (1969, p. 226). The model finds its theoretical background in mathematical models concerned with the social contagion of news. Since the early work of Bass several researchers have extensively explored which mechanisms constitute social contagion (Van den Bulte and Joshi, 2007b; Van den Bulte and Lilien, 2001; Van den Bulte and Stremersch, 2004b). The strength of the Bass model lies in the forecasting opportunities based on predictions about timing and magnitude sales and, in particular, the sales peak (1969, p.226). In contrast to the spread of innovations in homogeneous social systems as assumed by the early 'diffusionists', Chatterjee and Eliashberg (1990) were among the first to model the diffusion of innovation in a heterogeneous population (which had previously been suggested by Gatignon and Robertson (1985)). Specific attention have been devoted to international (spatial) diffusion models taking into account country characteristics including cultural determinants (Gatignon and Robertson, 1989; Hofstede and Hofstede, 2001; Tellis et al., 2003).

Although the Bass model has often been criticized, today's diffusion scholars continue to use the model; the renewed attention has been encouraged by several reviews and will be addressed in greater detail in Section 4.4 (Cluster 4) (Mahajan et al., 1990; Mahajan et al., 2000; Meade and Islam, 2006; Peres et al., 2010; Sultan et al., 1990; Wejnert, 2002). As a result diffusion models have been modified over time to improve their explanatory power (these modifications include the introduction of marketing variables in the parameterization of the models; generalizing the models to consider innovations at different stages of diffusion in different countries; and building models to consider the diffusion of successive generations of technology - particularly related to the diffusion of durables and communication technology) (Meade and Islam, 2006). 
Nevertheless, diffusion scholars face several challenges regarding anticipating on market trends such as opening up of markets in developing countries, Web-based services, virtual social networks, and complex product-service structure (Peres et al., 2010). In their review Meade and Islam (2006) suggest that future research should focus on forecasting new product diffusion with little or no data, forecasting with multinational models, and forecasting with multi-generation models. In addition Peres et al. (2010) suggest that in order for diffusion to remain a state-of-the-art modelling framework, research should be devoted to include additional growth drivers (in addition to interpersonal communications as a parameter); re-examine the metrics to describe both the level and variety of usage; and extend the range of data sources.

Two small subsets of articles were identified within Cluster D. The first subset addresses the diffusion of agricultural innovations (often from a policy-making perspective) (Feder and Umali, 1993; Foster and Rosenzweig, 1995). As demonstrated in Cluster 5 (see Section $4.5)$, this subset secured renewed interest by specifically addressing the "diffusion dynamics" in accordance with the work of Feder et al. (1985).

A second subset builds upon the effect of network ties with respect to social contagion and diffusion of innovation (Burt, 1987; Granovetter, 1973). It has been suggested that the tie strength between adopters (or non-adopters) being "structural equivalents" (i.e. very similar) is a predictor of innovation adoption. In this respect, Burt (1987) distincts between two types of diffusion models suggesting a debate between cohesion and structural equivalence models. Cohesion models build upon the notion that adopters resolve the uncertainty problem through conversations with peers in contrast to structural equivalence models which suggests that uncertainty of adoption is resolved through the perception of appropriate behaviour related to the social network position (Burt, 1987).

\subsubsection{Relative importance of the theoretical cornerstones}

The relative importance of the four cornerstones of innovation adoption have been assessed using citation-based statistics. Table 2.4 reveals that Cluster A ("Institutional theory and the legitimization of innovative behaviour ") and Cluster B ("Theory of Reasoned Action; Technology Acceptance Model") received, on average, the most citations from the 1260 articles included in the innovation adoption dataset. On average, the references in Cluster A and Cluster B have both been cited 44 times while Clusters C and Cluster D obtain substantially less citations, 41 and 37 respectively. Only Cluster A and Cluster B have been cited more than the average citation number $(42,07)$.

However, the Web of Science database consists of articles where all clusters also include some highly cited book publications, and the citation statistics from 2003 to 2016 cannot be derived from this database (Ajzen and Fishbein, 1980; Cyert and March, 1963; Fishbein and Ajzen, 1975; Pfeffer and Salancik, 1978; Porter, 1980; Rogers, 1962, 1983, 1995, 2003; Schumpeter, 1942). Books are therefore excluded from the citation impact analysis. 
Table 2.4: Indicators of publication output and citation impact (cited by the 1260 articles included in the dataset) per cluster of cited references

\begin{tabular}{|c|c|c|c|c|c|}
\hline Cluster & Label & $\begin{array}{l}\text { Number of } \\
\text { publications } \\
\text { (including } \\
\text { books) }\end{array}$ & Top 3 most-cited articles & $\begin{array}{l}\text { Average } \\
\text { number of } \\
\text { citations/ } \\
\text { article }\end{array}$ & $\begin{array}{l}\text { Ratio to } \\
\text { average } \\
\text { (sample) }\end{array}$ \\
\hline A & $\begin{array}{l}\text { Institutional theory and } \\
\text { the legitimization of } \\
\text { innovative behaviour }\end{array}$ & 44 & $\begin{array}{l}\text { (Dimaggio and Powell, } \\
\text { 1983): 105; (Cohen and } \\
\text { Levinthal, 1990): 92; (Grili- } \\
\text { ches, 1957): } 67\end{array}$ & 44,37 & 1,05 \\
\hline B & $\begin{array}{l}\text { Theory of Reasoned Ac- } \\
\text { tion and the Technology } \\
\text { Acceptance Model }\end{array}$ & 30 & $\begin{array}{l}\text { (Davis, 1989): 122; (Ven- } \\
\text { katesh et al., 2003): 99; } \\
\text { (Davis et al., 1989): } 90\end{array}$ & 44,36 & 1,05 \\
\hline C & $\begin{array}{l}\text { Determinants of innova- } \\
\text { tion adoption, an econo- } \\
\text { metric perspective }\end{array}$ & 35 & $\begin{array}{l}\text { (Tornatzky and Klein, } \\
\text { 1982): 97; (Damanpour, } \\
\text { 1991): 87; (Cooper and } \\
\text { Zmud, 1990): } 70\end{array}$ & 41,03 & 0,98 \\
\hline \multirow[t]{2}{*}{$\mathrm{D}$} & Diffusion Theory & 23 & $\begin{array}{l}\text { (Bass, 1969): 134; (Feder et } \\
\text { al., 1985): 66; (Mahajan et } \\
\text { al., 1990): } 57\end{array}$ & 36,67 & 0,87 \\
\hline & Total & 132 & & 42,07 & 1,00 \\
\hline
\end{tabular}

\subsection{Analysis of innovation adoption research trends based on bibliographic coupling}

In this section, we will unravel the current trends in the innovation adoption research by studying bibliographic coupling among the publications in our longitudinal dataset. Figure 2.6 illustrates a relatively coherent bibliographic network with five clusters of references cited by the 919 publications on innovation adoption published between 2003 and 2016. Clusters 1 to 4 are structured around a relative empty centre, which indicates that fields are more strongly tied than others (Van Eck and Waltman, 2010). Cluster 5, however, can be found in the periphery of the map with strong ties to Clusters 2 and 4 . In this respect, Cluster 5 is clearly separated from Clusters 1 and 3 . The identified clusters are labelled as follows: Cluster 1 -drivers and impediments of information technology adoption; Cluster 2 - the adoption of technology standards; Cluster 3 - organizational rationales associated with innovation adoption; Cluster 4 - modelling the diffusion process; and Cluster 5 adoption of agricultural innovations.

Table 2.5 presents an overview of the research trends reflected in Clusters 1 to 5 . We found that the research trends of the five clusters can be linked to a particular empirical field - Cluster 1 focuses on Information Technology, Cluster 2 focuses on technological standards, Cluster 3 focuses on management innovations, Cluster 4 on consumer durables and product innovations and Cluster 5 captures publications concerned with the adoption of agricultural economic innovations in developing nations. 
Column 4 highlights the theory on which it builds, with particular relevance to the theoretical cornerstones identified in Section 3. Cluster 1 builds upon Clusters B and C and specifically explores the determinants affecting the adoption and diffusion of IT innovations. Cluster 2 does not build upon a particular cluster identified in the previous section but explores the adoption of new and/or emerging technological standards related to sustainable technology. Theory development is principally related to technology trajectories; dominant designs and technology standards and the battle for dominance related to diffusion and change within a sector. Cluster 4 mainly takes into account the diffusion of consumer durables and product innovation; it focuses on the Bass Model that has been studied in many different fields. The "appendix", Cluster 5, addresses the dynamics of innovation adoption and diffusion. In the following section, we discuss the five clusters in greater depth adopting two perspectives: a representation of the field in which adoption has been studied, and the theoretical focus of the cluster.

Table 2.5: Overview of the 5 identified bibliographic coupled clusters

\begin{tabular}{llll}
\hline Cluster & $\begin{array}{l}\text { Builds upon } \\
\text { cluster: }\end{array}$ & Field under study & Theory \\
\hline 1 & B \& C & Information technology & $\begin{array}{l}\text { Diffusion of Innovations (DOI); Technology } \\
\text { Acceptance Model (TAM) } \\
\text { Diffusion of Innovations (DOI); Technology } \\
\text { trajectories; dominant design and tech- } \\
\text { nology standards; complementarities and } \\
\text { organizational capabilities }\end{array}$ \\
3 & None in particular & $\begin{array}{l}\text { Technology standards } \\
\text { (sustainable technologies) }\end{array}$ & $\begin{array}{l}\text { Behavioural Theory of the Firm; } \\
\text { Institutional Logic }\end{array}$ \\
4 & A & Management innovations & Bass Model \\
5 & D & $\begin{array}{l}\text { Consumer durables and product } \\
\text { innovation }\end{array}$ & $\begin{array}{l}\text { Agriculture innovation (in } \\
\text { developing countries) }\end{array}$ \\
\hline
\end{tabular}




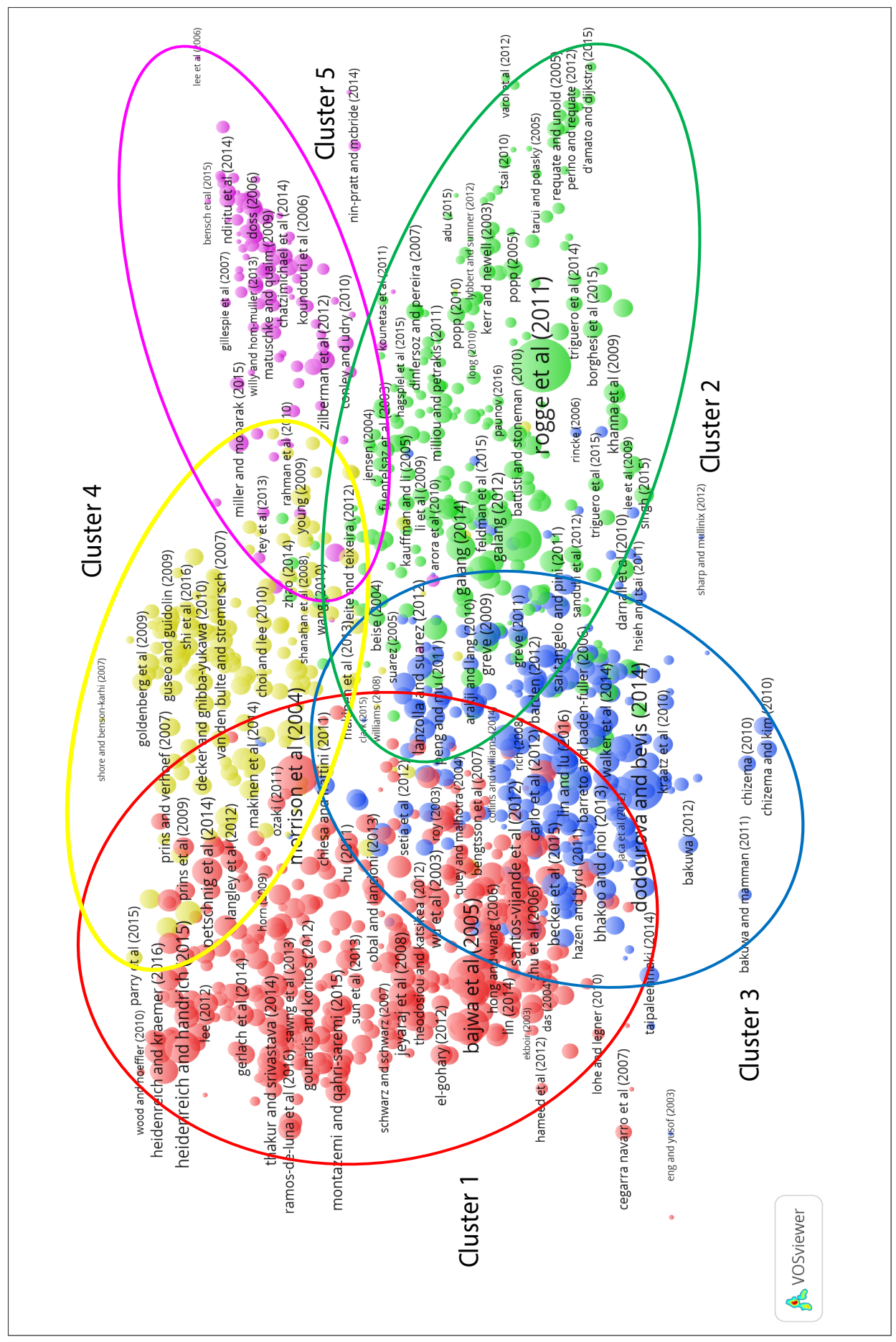

Figure 2.6: Bibliographic network of innovation adoption publications published between 2003 and 2016 


\subsubsection{Cluster 1: Drivers and impediments of information technology adoption}

Cluster 1 includes 433 articles and captures research that we labelled: "Drivers and impediments of information technology adoption". This cluster focuses mainly on the adoption of information technology and the determinants that impede or stimulate adoption. Cluster 1 builds upon Clusters A and C, which were important theoretical cornerstones in Section 3. Moreover, the articles included in this cluster focus predominantly on the contextual drivers and impediments of IT adoption, while Clusters A and C provide uniform models to explore the determinants of technology acceptance and adoption. Recurring IT technologies of interest include: education and E-learning; computer technology and Internet; supply chain management technology and RFID; E-commerce, mobile IT and E-business. Based on the density view it was found that Cluster 1 contains the most important part of the bibliographic network. Based on the density view two research themes were identified that are related to the drivers and impediments of IT adoption. The first theme address the an individual's intention to accept and adopt an IT innovation. In contrast, the second theme studies the acceptance and adoption of IT innovations at the organizational level.

The articles in Cluster 1 focus chiefly on the evaluation of drivers and impediments of IT adoption, which corresponds to the characteristics of Cluster C (see Section 3.3). The adoption determinants related to IT adoption can be assigned to three well-established categories of variables: technology determinants; organizational determinants, and environmental determinants (Bruque and Moyano, 2007; Hung et al., 2009; Molla and Licker, 2005a, b). In this respect, some refer to Tornatzky and Fleisher's (1990) Technology-Organization-Environment framework (Hong and Zhu, 2006; Wang et al., 2010).

In contrast to Cluster $C$, a common feature of the articles in this cluster is that they specifically take into account the drivers and impediments of adoption associated with the distinct stages of adoption or the specific adoption context. More specifically, several publications in this cluster study the effects of a firm's environment or supply chain on subsequent stages of IT innovation adoption, including the effect of network externalities (Del Aguila-Obra and Padilla-Melendez, 2006; Molla and Licker, 2005a; Patterson et al., 2003; Zhu et al., 2006). Thus, Cluster 1 connects to the Downs and Mohr critique as discussed in section 3.3 (cluster $\mathrm{C}$ ).

We also found a group of articles that draws on an established framework, the Technology Acceptance Model, as found in Cluster A (see Section 3.2) (Bruner and Kumar, 2005; Lewis et al., 2003; Wu and Wang, 2005). The Technology Acceptance Model and insights from the Theory of Planned Behaviour and the Theory of Reasoned Action have been applied to research both the adoption of IT by individuals and organizations. Several authors have tried to extend or even alter the model while others have "borrowed" several adoption mechanisms from the Diffusion of Innovations, the Reasoned Action and Firm Behaviour line of debate in order to develop a more integrated model. As a result these authors inte- 
grated several innovation characteristics (compatibility, cost and perceived risk) from the Diffusion of Innovation Theory and determinants from Firm Behavioural Theory into the Technology Acceptance Model (Hong and Tam, 2006; Hsu et al., 2007; Karahanna et al., 2006; Teo and Pok, 2003).

\subsubsection{Cluster 2: The adoption of technological standards}

Cluster 2 includes 267 articles and the research trend it represents is labelled as: "The adoption of technological standards". This cluster deals with technological change that overturns existing technological standards of which some are considered as General Purpose Technology, i.e. innovation relevant to a wide range of industries and subsequently changes modes of production and operation (Bresnahan and Trajtenberg, 1995; Fabiani et al., 2005; Feldman et al., 2015). Subsequently, the key question is how these newer technological standards will be adopted as well as to what extend (depth of adoption). Cluster 2 does not build upon a particular cluster identified as a theoretical cornerstone in Section 3. The articles within this cluster primarily studied adoption (timing) of new technological standards from an econometric point of view and expressed in mathematical representations. Surprisingly, the most cited articles were located in the periphery of the cluster and, with a few exceptions, focus on technology change instruments (i.e. policies) that sustain the transition of standards.

The common thread in the first research stream derived from the articles is that they assume that technology adoption involves three decisions including (Åstebro, 2004): 1) whether to adopt or not, 2) extend of exploiting the innovation (depth of adoption), and 3) replacement speed of old by the new technology. Subsequently, different models have been developed to address these research questions (see Table 2.6). Next, attempts have been made to develop a diffusion model which includes both inter-firm diffusion concerning the adoption decision as well as the intra-firm diffusion with respect to the depth of adoption and includes determinants related to rank, epidemic, stock and order effects (Åstebro, 2004; Battisti and Stoneman, 2005; Fuentelsaz et al., 2009; Fuentelsaz et al., 2003; Hollenstein and Woerter, 2008; Karshenas and Stoneman, 1993). More precisely, these determinants include firm characteristics (including technical prerequisites and absorptive capacity), environment and industry characteristics, epidemic or learning effects and the cost and benefits of usage. It is assumed that these determinants reflect both inter and intra-firm diffusion (Hollenstein and Woerter, 2008).

Some scholars have assessed some of the previous aspects more specifically related to innovation diffusion. Building upon the work of Milgrom and Roberts (1990b, 1995), Bocquet et al. (2007) emphasized that the adoption is not merely affected by traditional adoption variables but also by complementarities between organizational characteristics concerning strategies, organization and information technologies. The complementarity or supermodularity view assumes that the adoption of a new technology only contributes to organizational performance if it matches with other organizational practices. 
In this line of reasoning similar findings have been reported by Fabiani et al. (2005) who claims that adoption is just one component of a complex process of change. Furthermore, it has been emphasized that complementarities between multiple technologies should be taken into account while it could affect the adoption decision of (multiple) technologies when it complements or substitutes a technology (Arora et al., 2010; Colombo et al., 2013; Gomez and Vargas, 2009). Next, to enable adoption, to develop complementary assets and capabilities and to benefit from innovation, organizations need to learn to adjust the organization to the innovation which it intends to adopt (BEN-NER and Lluis, 2011).

Table 2.6: Articles of Cluster 2 address the battle for dominance between two technology standards and focus on one of the five research questions.

\begin{tabular}{ll}
\hline Research question & Model \\
\hline $\begin{array}{l}\text { Whether and when to adopt? } \\
\text { When to adopt a new network externalities technology? }\end{array}$ & $\begin{array}{l}\text { Real Options Model (Kauffman and } \\
\text { Li, 2005; Li, 2009) } \\
\text { Discrete Choice Model (Forman, 2005; } \\
\text { Suarez, 2005) }\end{array}$ \\
$\begin{array}{l}\text { How to break through technology standards and speed up the diffusion of } \\
\text { new technology standards? }\end{array}$ & $\begin{array}{l}\text { What is the effect of time-related variables on adoption during a) the sub- } \\
\text { sequent stages of individual decision making, or b) the subsequent stages } \\
\text { of diffusion? }\end{array}$ \\
$\begin{array}{l}\text { Whether and when to invest in adoption? } \\
\text { 2003) }\end{array}$ & $\begin{array}{l}\text { Dynamic Investment Game Model } \\
\text { (Schivardi and Schneider, 2008) }\end{array}$ \\
$\begin{array}{l}\text { Which thresholds have to be taken into account during the diffusion of a } \\
\text { new standard and when? }\end{array}$ & $\begin{array}{l}\text { Threshold Model (Lissoni, 2005) } \\
\end{array}$
\end{tabular}

Second, with respect to the adoption of technology standards, the most cited articles in Cluster 2 focus on the effect of policy instruments on adoption and, more specifically, on the context of environmentally friendly technology. In particular, policies that stimulate the development and adoption of environmentally beneficial technology has earned considerable attention. Scholars have applied integral conceptualizations to study the effect of governmental policies on adoption by focusing on the nexus between technology and environmental policies (Jaffe et al., 2005; Requate, 2005a, b; Requate and Unold, 2003) and on the nexus between incentive- and prescriptive-oriented policy instruments (Kerr and Newell, 2003; Taylor et al., 2005). Several articles address the adoption of environmental innovation at the global level, where environmental innovations diffuse internationally (Beise, 2004; Beise and Rennings, 2005; Erumban and de Jong, 2006).

\subsubsection{Cluster 3: Organizational rationales associated with innovation adoption}

Cluster 3 includes 258 articles: the research trend it represents has been labelled as: "Organizational rationales associated with innovation adoption". Cluster 3 has a common focus on the institutionalization of management systems such as the adoption of Management Control Systems (MCS) (Davila et al., 2009), High Performance Work Organizations (Kim and Bae, 2005) including Lean management techniques (Jaca et al., 2012) and Performance 
Management among sub-units within a multinational (Lervik and Lunnan, 2004). Cluster 3 is nestled between cluster 1 and 2 in the map. From this it can be derived that while management innovations are often adopted together with or complementary to IT and technology innovation (subsequently cluster 1 and 2), these research fields are closely positioned next to each other.

Why do organizations innovate? More specifically, why do organizations decide to (or intent to) adopt and subsequently implement innovations? The articles included in cluster 3 build upon the Schumpeterian law that innovation is deemed necessary with respect to competitive advantage and economic growth. Cluster 3 in particular links organizational practices to adoption emphasizing that traditional economic factors only explain a limited proportion of the variability of innovation adoption across firms. This notion has led to the suggestion that it is necessary to consider alternative explanations building upon the organizational rationality and routines as can be found in theory about evolutionary economics and institutional change (Compagni et al., 2015; Daniel et al., 2012). Moreover, recently the work of Birkinshaw et al. (2008) made scholars consider that management innovations enable the adoption of technological innovation as organizations need to build capabilities to do so (Khanagha et al., 2013; Lin et al., 2016).

Traditional adoption research has tended to emphasize the importance of innovation characteristics, in terms of economic efficiency, on the decision-making process leading to adoption, referred to as the "pro-innovation bias" (Greve, 2011; Rogers, 2003). Moreover, following the theoretical cornerstone of Cluster D, articles in this cluster have contributed to several "sub-theories" related to the Behavioural Theory of the Firm (Argote and Greve, 2007) including neo-institutional theory and the Resource-Based View. Neo-institutional scholars Barreto and Baden-Fuller (2006) identified the following lacunas in the literature with respect to innovative firm behaviour: 1) who imitates whom? 2) do imitating firms distinguish between "good" and "bad" options? and 3) what is the effect of mimic isomorphism on firm performance? Barreto and Baden-Fuller suggest that organizations apply a legitimacy-driven framework when imitating legitimacy providers, which act as "reference points" or "guides" in a complex and hostile firm environment. Thus, gaining legitimacy has a substantial effect on organizational decision making. Moreover, a dualism between "pressure to conform" and "pressure to perform" can be noted, according to these authors.

Several articles build upon theoretical concepts embedded in Neo-institutional theory and have assessed the habits (Reay et al., 2013); memetics (O'Mahoney, 2007); logic (Cheng, 2010); meaning (Love and Cebon, 2008), vision (Ramiller and Swanson, 2003), analogies (Etzion and Ferraro, 2010), and rationales (Daniel et al., 2012) related to innovation adoption. In addition, as witnessed in Cluster D, Abrahamson $(1991,1996)$ introduced the concept of "management fashion", which has been further explored by Baskerville and Myers (2009) and Wang (2010). 
Following Baskerville and Myers, management fashion is defined as "a relatively transitory belief that a certain management technique leads rational management progress" (p.647). From the Neo-Institutional perspective, management-setting organisations, which are by definition located outside the group of followers, shape the belief that certain management practices are rational, state-of-the-art and "the right thing to do", and that subsequently they will be imitated by fashion followers. Addressing the innovation-diffusion perspective and, in particular, the pro-innovation bias, some organizations imitate fashionable innovations under conditions of uncertainty concerning environmental forces, organizational goals and efficiency, even when they have no utility for the imitating organization (Abrahamson, 1991, 1996; Baskerville and Myers, 2009; Wang, 2010).

From a Behavioural Theoretical standpoint, some studies attempted to combine several theoretical perspectives into an integrative framework. Basaglia et al. (2009), for example, integrated the institutional-, management fashion-, and efficient-choice perspectives into a single theoretical model. Furthermore, Cheng (2010) addressed both institutional and organizational learning theory. Massini et al. (2005) attempted to align Behavioural Theory and Institutional Theory. Another group of scholars have drawn upon the Resource-Based View (RBV) of organizations and considered the effect of organizational resources, social network ties and learning capabilities on adoption (Damanpour et al., 2009; Greve, 2009; Lee and Grewal, 2004). Again, these publications build upon the theoretical assumptions in Cluster D.

\subsubsection{Cluster 4: Modelling the diffusion process}

Cluster 4 includes 180 articles; the research trend it represents has been labelled as: "Modelling the diffusion process". The articles in Cluster 4 all focus on mathematical representations of the innovation-diffusion process building upon the theoretical assumptions of Cluster B. Compared to the previously discussed clusters, Cluster 4 is not related to any specific field, while the model is applicable to an evaluation of a wide variety of innovations within diverse industries and sectors. Nevertheless it was found that many articles in Cluster 4 researched the diffusion of durables and product innovations.

The bulk of articles included in Cluster 4 deal with revising the Bass Model. The Bass Model has been criticised from the outset by scholars claiming that the model is too simplistic. Adjustments and additions have been suggested such as incorporating price development and marketing indicators (Bass et al., 1994; Prasad and Mahajan, 2003). Recent studies have further refined the Bass Model to better forecast and describe diffusion by addressing the dynamics of diffusion including the effects empowered by policies, social network structure and heterogeneity and product evolution. Moreover, research about diffusion dynamics have addressed issues about how dynamic communication networks among adopters affect knowledge distribution and related innovation adoption (Centrone et al., 2007; Guseo and Guidolin, 2009, 2011) and the effect of incremental improvement or evolutionary innovation (Orbach and Fruchter, 2011; Pae and Lehmann, 2003). For exam- 
ple, Rahmandad and Sterman (2008) discussed when to apply agent-based (AB) models and when to opt for differential equation models (DE) while modelling dynamic diffusion processes, taking into account network structure and heterogeneity (examples of both can be found in Cluster 4).

Building on the Bass Model, the authors of the highest cited articles in this cluster have focused on the effect of social contagion, referred to as "social influence" or "social learning", and the effect of social heterogeneity on diffusion (Iyengar et al., 2011; Manchanda et al., 2008; Schlereth et al., 2013; Van den Bulte and Joshi, 2007a; Van den Bulte and Stremersch, 2004a; Young, 2009). For example, Van den Bulte and Stremersch's (2004, p.530) definition of social contagion refers to actors' adoption as "a function of their exposure to other actors' knowledge, attitudes, or behaviours concerning the new product" (Van den Bulte and Stremersch, 2004b). Moreover, viral marketing builds on the characteristics of social contagion and especially (electronic) word-of-mouth (De Bruyn and Lilien, 2008; Garber et al., 2004). De Bruyn and Lilien (2008), for example, studied the role that word of mouth and the effect of social tie characteristics plays during each stage of decision making.

Other themes have been studied as well. First, several authors focused on country-specific effects on innovation adoption and on innovation spill over between countries (Sundqvist et al., 2005; van Everdingen et al., 2009; Van Everdingen, 2003). Next, some scholars took into account network externality effects. Fornerino (2003), for example, applied the Non-Uniform Influence (NUI) Model developed by Easingwood et al. (1983) to study the diffusion of the Internet in France. The NUI equations differ from the Bass equation in that it takes into account an (exponential) enhanced influence of interpersonal communication.

\subsubsection{Cluster 5: Adoption of agricultural innovations}

Cluster 5 includes 112 articles; the research trend it represents have been labelled: "Adoption of agricultural innovations". The cluster can be found in the periphery of the network close to Clusters 2 and 4 and at arm's length from Clusters 1 and 3. More precisely, it is unlikely that Cluster 5 is cited with Clusters 1 and 3 . The articles in Cluster 5 address innovation adoption-diffusion from an economic theory perspective. A large set of articles in Cluster 5 consider the effect of technology adoption on economic growth and increased welfare in developing countries. In general, these technologies encompass agricultural innovations such as fertilizers, intercropping, and the use of new (bio-engineered) seed varieties. Moreover, several articles focus on the impact of technology adoption on efforts to reduce the environmental impact of agricultural practices such as organic farming (Burton et al., 2003) and conservation tillage (D'Emden et al., 2006; Marshall, 2009). Finally, some studies deal with innovations that reduce environmental impact and increase the economic performance of biotechnology. 
An influential review often referenced in articles in Cluster 5 is the article by Feder et al. (1985). Several publications in Cluster 5 address Feder, Just and Zilbermann's notion of "the dynamics of adoption" (Carletto et al., 2010; D’Emden et al., 2006; Koundouri et al., 2006; Laepple, 2010; Marenya and Barrett, 2007). This review in particular shows how Cluster 5 relates to Cluster 4 . In line with this review, a distinction can be made between adoption studies modelling the adoption of an innovation at a specific point in time and diffusion studies that model the cumulative dissemination of an innovation. Following Davies (1979), the criticism has been made that many adoption models depend on cross-sectional data and neglect the impact of time-dependent determinants such as price variation over time. To address this critique, several scholars in this cluster used Duration Analysis (historically used to model epidemiological phenomena) including both cross-sectional and time-series determinants (Koundouri et al., 2006).

Several dimensions of adoption dynamics have been addressed, such as the importance of learning, information acquisition, and personal perceptions that effect change over time because its inherent value changes (D'Emden et al., 2006). Some authors implicitly address the adoption dynamics bias. For example, Conley and Udry (2010), the most cited article in Cluster 5, developed a model that takes into account the role of social learning in the diffusion of new agricultural technology - an approach that is closely related to the social contagion concept (see Cluster 4). Others have focused on the determinants that lead to "disadoption", i.e. discontinuance or abandonment, which is considered to be another dynamic dimension (Carletto et al., 2010; Laepple, 2010; Marenya and Barrett, 2007). Some methodological issues related to this line of debate have been addressed by Diagne and Demont (2007) and Doss (2006). Diagne and Demond (2007) address two types of bias related to commonly used adoption rates estimators, and Doss (2006) conducted an extensive literature review suggesting alternative approaches to designing technology adoption studies, referred to as the second generation of agricultural innovation diffusion research.

\subsubsection{Relative importance of bibliographic-coupled clusters}

Table 2.7 presents some citation-based statistics to assess the relative importance of the five clusters identified. Table 2.7 shows that Cluster 1 received the most citations per article by far, in contrast to Cluster 3 which seems to be a less popular research trend. The conclusion holds if one controls for the number of publications per cluster or for the average number of citations per article per year. Thus, Cluster 1 on the "Drivers and impediments of information technology (IT) adoption" can be pinpointed as the most cited cluster, with Cluster 2 ("The adoption of technological standards") having an average impact.

Figure 2.7 shows the number of publications per cluster from 2003 to 2016 . Cluster 2, 3 and 4 have trend lines with both peaks and saddles. Cluster 5 , the smallest cluster with a relative low impact, shows a relatively stable pattern. Cluster 1 shows a steady grow of articles per year up till 2010. After 2010 this research trend seems to lose the interest of scholars with a drop in the number of publications. In general, the total number of articles 
published per year in the field of innovation adoption dropped in 2013 after which the number publications increased again on a yearly bases (for the year 2016, from January to October about 80 scientific articles have been published).

Table 2.7: Indicators of publication output and citation impact per thematic cluster

\begin{tabular}{lccccc}
\hline Cluster & $\begin{array}{l}\text { Number of } \\
\text { articles }\end{array}$ & Average age & $\begin{array}{l}\text { Total number of } \\
\text { citations }\end{array}$ & $\begin{array}{l}\text { Average number } \\
\text { of citations/ } \\
\text { article }\end{array}$ & $\begin{array}{l}\text { Average number } \\
\text { of citations/ } \\
\text { article/year }\end{array}$ \\
\hline 1 & 432 & 4,88 & 5028 & 11,64 & 2,39 \\
2 & 267 & 5,03 & 2332 & 8,73 & 1,74 \\
3 & 258 & 3,93 & 1311 & 5,08 & 1,29 \\
4 & 180 & 4,68 & 1405 & 7,81 & 1,67 \\
5 & 113 & 5,42 & 860 & 7,61 & 1,41 \\
Total & 1250 & 4,70 & 10936 & 8,75 & 1,86 \\
\hline
\end{tabular}

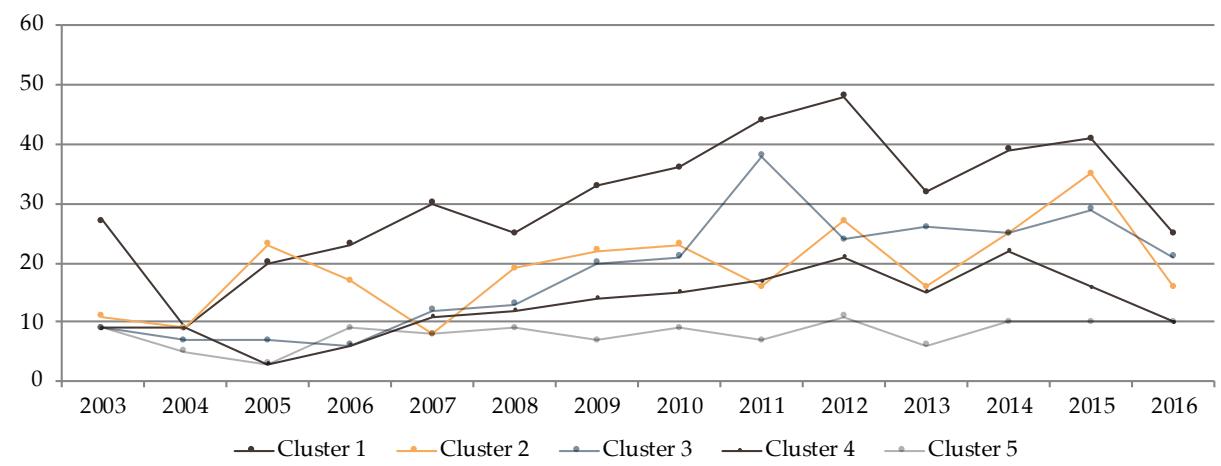

Figure 2.7: Number of publications per year per cluster

One could wonder how this bibliometric study confirm or dispel from previous reviews of the innovation adoption literature. Therefore we compared the findings with innovation adoption reviews which are published in the period 2013-2017. By consulting the WoS database we identified 1 bibliometric review, 2 scoping reviews, 4 meta-analyses, and 42 systematic, qualitative reviews. After close examination of the theoretical concepts and field of study, three observations were made. First, we found that 13 reviews could not be linked to a particular theoretical framework, i.e. these reviews aim at providing an overview of the variables affecting the adoption-diffusion of innovation. Second, out of these 49 studies, 34 articles include one or several theoretical frameworks linked to the adoption of innovation within a specific field. 
Finally, 47 reviews could be linked to the adoption of innovation within specific fields: health care (11); eco-innovation and agriculture (16); information and communication technology (9); business economics and new product introduction (11). In line with Wong et al. (2010) and Wisdom et al. (2014) we consider these reviews as efforts to constitute 'middle-range theories' of innovation adoption (Wisdom et al., 2014; Wong et al., 2010).

Next, the 2 remaining reviews which we identified could not be linked to a specific research field (i.e. Kapoor et al. (2014); Sriwannawit and Sandström (2015)). Kapoor et al. (2014) reviewed Rogers' innovation adoption attributes in order to develop a guideline to the ideal innovation-attribute studies. Sriwannawit and Sandström (2015) conducted a bibliometric analysis of innovation diffusion literature and identified 13 clusters, comprising 6,811 publications over the period of 2002-2011. The main difference with our bibliometric review encompass the distinction between theoretical cornerstones and recent research trends in innovation adoption research, i.e. some of the clusters identified by Sriwannawit and Sandström are considered as theoretical cornerstones in this review rather than current research trends. In our study we applied two distinct bibliometric approaches to distinct between theoretical cornerstones and research trends which are subsequently explicitly linked to each other.

Based on the theoretical concepts and field of study we cross referenced the 48 reviews with the theoretical cornerstones and research trends identified in this bibliometric study. Therefore we constructed the framework as illustrated in Figure 2.8. This analysis shows that the theoretical cornerstones and research trends identified are robust while we were also able to cross reference the review articles with our bibliographic study. While most of the identified reviews are considered middle-range theories of innovation adoption, this framework contributes by organizing the middle-range theories of innovation adoption. A parallel contribution of our bibliometric study is that it confirms that previous, mostly qualitative reviews, contribute to 'disentangle the forest of scientific publications' about innovation adoption. In line with previously conducted bibliometric studies (Furrer et al., 2008; Marzi et al., 2017), both type of reviews are valuable and complementary and therefore this bibliometric study may also be used to validate previous interpretations. 
Research trends

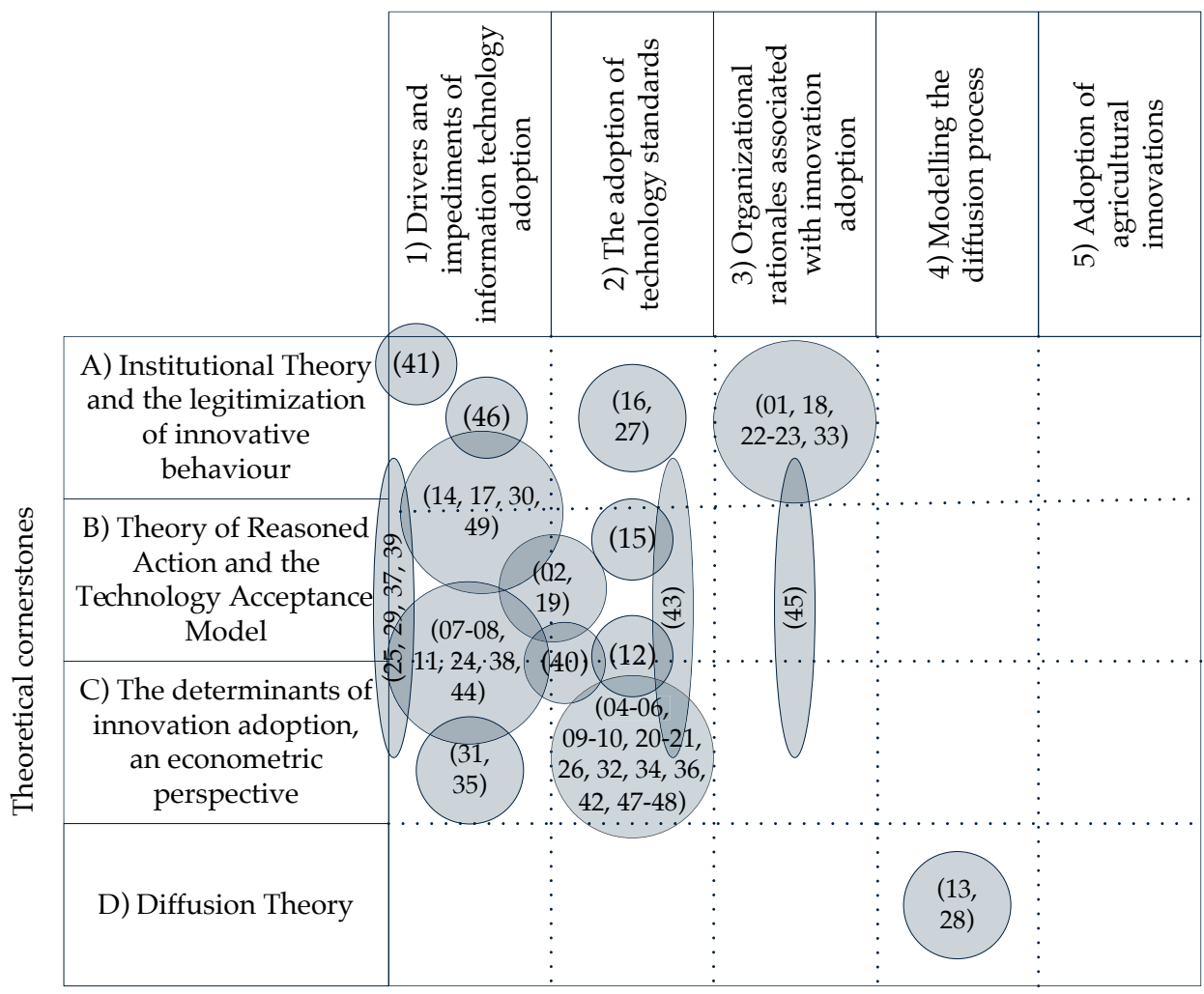

[01] (Aarikka-Stenroos et al., 2014) [17] (Ingebrigtsen et al., 2014)

[02] (Adnan et al., 2017a; Adnan et al., [18] (Innis et al., 2015) 2017b; Adnan et al., 2017c)

[03] (Allen et al., 2017)

[04] (Bossle et al., 2016)

[05] (Byambaa et al., 2015)

[06] (Candas et al., 2016)

[07] (Cresswell and Sheikh, 2013)

[08] (De Grood et al., 2016)

[09] (Ellabban and Abu-Rub, 2016)

[10] (Estem et al., 2016)

[11] (Gagnon et al., 2015)

[12] (Gangwar et al., 2014)

[13] (Goodwin et al., 2014)

[14] (Hanafizadeh et al., 2014)

[15] (Hasler et al., 2017)

[16] (Hojnik and Ruzzier, 2016)
[19] (Kapoor et al., 2014)

[20] (Karakaya \& Sriwannawit, 2015)

[21] (Karakaya et al., 2014)

[22] (Kelly et al., 2017)

[23] (Khanassov et al., 2014)

[24] (Khong et al., 2015)

[25] (Kruse et al., 2014)

[26] (Lefebvre et al., 2015)

[27] (Lyle, 2015)

[28] (Moglia et al., 2017)

[29] (Molinillo and Japutra, 2017)

[30] (Montazemi \& Qahri-Saremi, 2015)

[31] (Mwirigi et al., 2014)

[32] (Nejad et al., 2014)

[33] (Novins et al., 2013)
[34] (Ortiz et al., 2017)

[35] (Radu, 2016)

[36] (Rahbauer et al., 2016)

[37] Rana et al. (2015)

[38] (Rezvani et al., 2015)

[39] (Sanakulov \& Karjaluoto, 2015)

[40] (Sovacool and Hess, 2017)

[41] (Sriwannawit \& Sandström, 2015)

[42] (Tayouga and Gagné, 2016)

[43] (Varabyova et al., 2017)

[44] (Williams et al., 2015)

[45] (Wisdom et al., 2014)

[46] $(\mathrm{Wu}, 2016)$

[47] (Yeatts et al., 2017)

[48] (Zanello et al., 2016)

[49] (Zhang et al., 2014a)

Figure 2.8: Cross reference of 49 recently published reviews with the theoretical cornerstones and research trends of innovation adoption research 


\subsubsection{Summary}

In the previous sections, we presented a novel, systematic and comprehensive review of the bibliographic literature (including 1260 articles) to identify the theoretical cornerstones and research trends in innovation adoption research. This study complements existing reviews in various ways. First, based on co-citation analysis, we illustrate that innovation adoption research is built on four theoretical cornerstones (or in terms of bibliographic clustering, four clusters of prior publications): A) Institutional Theory and the legitimization of innovative behaviour; B) Theory of Reasoned Action and the Technology Acceptance Model; C) The determinants of innovation adoption, an econometric perspective; and D) Diffusion Theory.

Second, bibliographic coupling was used to assess the current research trends in the innovation adoption literature. This review is the first to identify thematic areas in an exhaustive manner. The bibliographic coupling technique revealed five clusters of thematic related publications or "research trends": 1) Drivers and impediments of information technology adoption; 2) The adoption of technological standards; 3) Organizational rationales associated with innovation adoption; 4) Modelling the diffusion process and; 5) Adoption of agricultural innovations. Within the bibliographic network, one of the clusters, Cluster 5, can be found in the periphery of the structure. It appears that Cluster 5 cannot be regarded as a mainstream thematic area as it is so closely related to Clusters 2 and 4 .

Third, we were able to construct a coherent framework to assess the relevance of innovation adoption research by integrating the theoretical cornerstones and the current research trends. As a parallel contribution we found that previous conducted overview studies contributed to a coherent understanding of innovation adoption in specific fields and are bound together by the present bibliometric study.

\subsubsection{Future research}

In this section we present several important areas in the field of innovation adoption and diffusion that merit future research.

The development of more holistic theoretical explanations in the field of innovation adoption and diffusion. This bibliometric review revealed that adoption and diffusion research is highly segregated. Researchers mostly build upon conceptualizations related to a single research stream, which are often applied to explain the adoption of specific innovations within a single context. To create more holistic theoretical explanations of innovation adoption and diffusion, we would encourage future studies to investigate the adoption and diffusion mechanisms related to specific innovations across different contexts. 
Detailed investigations of the distinguished research streams. The identified research streams include up to 400 articles, and thus encompass multiple theoretical concepts, which could be subject to fine grained content analysis (White and McCain, 1998a). Every single research stream encompasses multiple articles which could be assessed by applying bibliometric and text mining techniques as has been demonstrated by Randhawa et al. (2016) in their literature review about open innovation and which includes 321 journal articles about open innovation.

Exploration of the explanatory power of psychological and organizational theories. Despite the maturity of the field of innovation adoption research we suggest to further explore other theoretical perspectives used in e.g. management, marketing and organization behaviour which have not received much attention yet in the field of innovation adoption research. Doing so can help to further advance our understanding of innovation adoption. As a first example, while adoption involves decision-making, we expected that cognitive processes underlying human thought, knowledge and decision-making would hold a more prominent position in innovation adoption research. Theoretical concepts such as prospect theory (Aarikka-Stenroos et al., 2014; Innis et al., 2015; Radu, 2016), bounded rationality (Adnan et al., 2017b) and stakeholder theory (Adnan et al., 2017c) may help to understand which heuristics decision makers apply when considering the adoption of a specific innovation.

A second example of an underused theory concerns the innovation systems theory. This theory emphasizes that innovation systems should be considered as an important determinant of transition and change within an industry sector (Hekkert et al., 2007). Innovation system research builds on the notion that (technological) niche innovations alone are not enough to sustain change but require subsequent innovations in the social domain to pave the way. Innovation and change in the social domain shape user practices, regulation and standards, and industry networks which create technological transition and socio-technical transformation (Geels and Schot, 2007).

An empirical lens to identify white spots in innovation adoption literature. Given the growing importance and attention in the last decade for service innovation research, we would also expect an increased stream of research about the potential adoption of service innovations. With a focus on the potential adoption of IT Innovations, Cluster 1 addresses an important, yet only limited subset of potential research in the adoption of service innovations. Also the question how IT as an enabler could stimulate the adoption of new products and services, still remains unanswered. While Cluster 2 and 3 reveal the results of research on the enabling effects of complementary innovations and (organizational) capabilities, research on the enabling effect of IT on the adoption of innovations may still be considered as a white spot in literature. A final suggestion for future research is related to the use of modularity principles and the application of product and process platforms in the industry. 
While we observe a substantial increase of research in this field, literature about the adoption dynamics and the mechanisms which drive the adoption and diffusion of module and platforms based innovations are still limited.

\subsubsection{Limitations}

Through the use of a bibliometric review methodology, this study reduced the bias that is often associated with expert surveys and traditional reviews (Kovacs et al., 2015). Nevertheless, a limitation of this review is the direct consequence of the application of a bibliometric review methodology. Despite its advantages to overcome bias, bibliometric analyses cannot replace, rather merely complement, extensive reading and finegrained content analyses (Schraven et al., 2015; White and McCain, 1998a). Based on 1260 journal articles referring to almost 46,000 publications, it is hardly possible to extensively discuss all the (middle range) theoretical concepts revealed by all these articles. Therefore, this review is limited to the identification of the theoretical cornerstones and main research trends in the field of innovation adoption, acceptance and diffusion. 



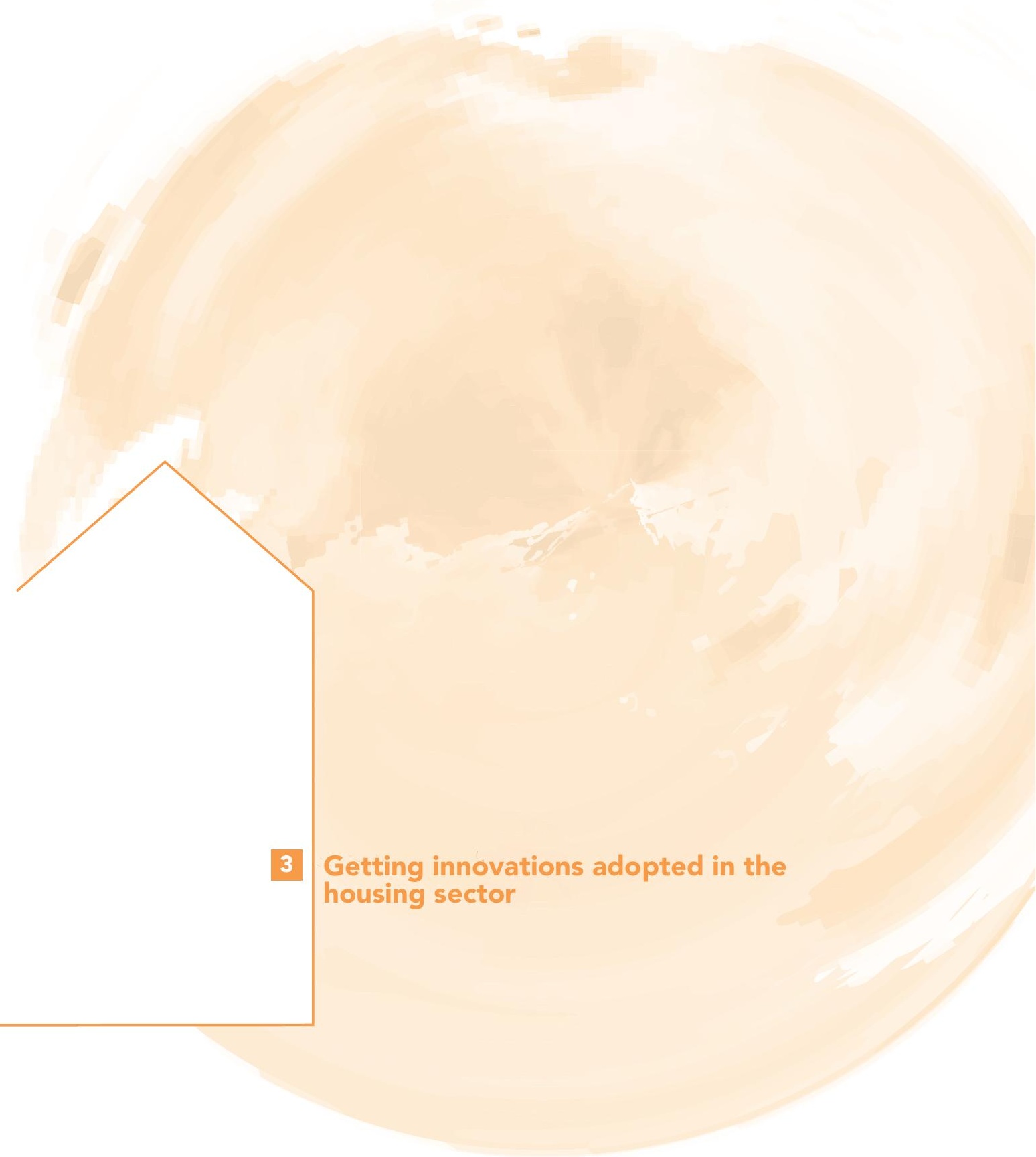




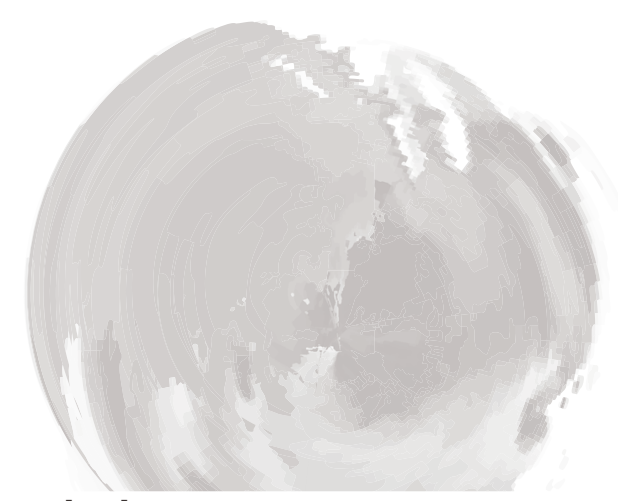

\section{Getting innovations adopted in the housing sector}

This chapter has been published in Construction Innovation ${ }^{13}$

\section{Abstract}

Innovation is not only key to firm survival but also necessary to modernise the housing sector to improve its overall performance, in particular with respect to production efficiency and sustainability. To this end innovations need to be adopted at a large scale. This systematic, narrative literature review aims to bring together a fragmented body of literature concerning this issue. This study presents the state of knowledge about the adoption of innovation in the housing sector. Based on the unit of analysis by the studies included in our review, we present a taxonomy of housing innovation and we conclude that, typical for low-tech industries, no radical, discontinuous innovations were reported in the field of housing. Based on the dataset of this review a coherent framework has been developed which includes four categories of determinants and underlying variables. Subsequently, 21 propositions have been deduced, which reflect the key mechanisms affecting the adoption of innovation in housing. This framework not only provides an explanatory overview about innovation adoption in the housing sector but also provides insight to managers how to increase the chances to get their innovations adopted in the housing sector. The review concludes with the limitations and future research orientations.

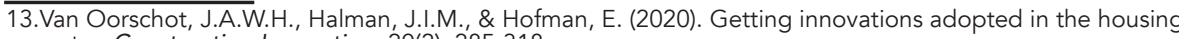
sector. Construction Innovation, 20(2), 285-318. 


\subsection{Introduction}

Housing projects continue to be plagued by cost and time overruns, low productivity and inefficiency, housing quality issues and a high environmental impact. Innovative solutions, developed within the housing sector or supplied by other industries, are considered necessary to overcome these deficiencies. The awareness of the necessity of innovation in the housing sector has grown in the past decades, which is reflected in the increasing number of scientific and professional publications about this topic. Despite the availability of innovations, the overall innovation performance of the housing sector falls short, primarily because of the poor adoption and lack of a widespread diffusion of innovations.

Rogers (2003) conceptualized innovation adoption as a communication process in which adoption reflects a pattern of information flow about an innovation. Following Rogers' conceptualization of innovation adoption, we define innovation adoption in the housing sector as: a communication, learning and decision making process about the application of an economic valuable and non-trivial improvement in a product, process, or system relevant to the construction of housing, which is novel to one or several stakeholders involved in the housing project.

With respect to the adoption and further diffusion of innovations, it is widely recognized that the housing sector differs in particular from other sectors because of its loosely coupled, fragmentary production network (Dubois and Gadde, 2002; Gann and Salter, 2000; Taylor and Levitt, 2007). In this respect, several researchers indicated construction, including housing, as an archetypal network industry because of the collaboration of multiple stakeholders to construct buildings (Miozzo and Dewick, 2004). This network reflects numerous interfaces, both technological and organizational, which are complex to coordinate since these interfaces need to be managed within multi-actor projects. The complex structure of the housing sector, which is based on temporary networks of many stakeholders who are forced to collaborate with each other, is considered a key barrier to both the development and adoption of innovation (Berardi, 2013; Bygballe and Ingemansson, 2014; Dubois and Gadde, 2002; Gann and Salter, 2000; Hoppe, 2012). This argues for the importance of innovation adoption research in the housing sector.

A number of arguments speak for the theoretical and practical relevance of producing a systematic narrative review on the adoption of innovation in the housing sector. First, as has been emphasized by Brown and Eisenhardt (1995), reviews are particularly useful when a growing body of literature, such as about innovation adoption in housing, has not been tied together into a coherent framework.

As a result it is difficult to grasp what is actually known (Brown and Eisenhardt, 1995; Keupp et al., 2012). Systematic narrative reviews apply explicit and transparent methods to conduct a thorough search and critical appraisal of individual research projects to draw conclusions about what currently is known and not known about a field of research such as innovation adoption (Briner and Denyer, 2012; Tranfield et al., 2003). 
Second, despite that several researchers have studied innovation adoption in the housing sector, a comprehensive model explaining the adoption of innovation in that particular context is still lacking. The lack of such a model has been cited as an important shortcoming in literature (Dieperink et al., 2004). Third, the absence of such a model complicates well-informed decision-making by practitioners and policy-makers to sustain innovation in the housing sector and improve construction practices in housing projects (Popay et al., 2006).

The aim of this paper is to present a systematic narrative review concerning the adoption of innovation in the housing sector. Therefore, we address the following research question: which determinants affect the adoption of innovation in housing projects? By addressing this research question, this paper contributes to the innovation literature in three ways:

1. It presents a taxonomy of innovations specific to the housing industry;

2. It organizes 'the adoption of innovation in housing' literature and synthesizes the mechanisms that stimulate and hinder the adoption of innovation in housing projects into a coherent framework.

3. It presents propositions for future research.

This study is organized as follows. In the next section we discuss the method we followed for this literature review. In section 3.3, we categorize the identified innovation adoption literature in the housing sector according to the applied theoretical concepts and classify the different types of innovations by using Henderson and Clark's (1990) conceptual framework of innovation. This section is followed (Section 3.4) by a synthesis of the identified adoption mechanisms into a coherent conceptual framework of innovation adoption in the housing sector. Moreover, we also deduce 11 determinants with a positive effect and 10 determinants with a negative effect on the adoption of innovation in the housing sector. Finally, in Section 3.5, we discuss the contributions and limitations of this review and make recommendations for future research. 


\subsection{Methodology}

The systematic narrative review method was selected for the purpose of developing a conceptual framework to tie together research concerning the adoption of innovation in housing projects, and subsequently to identify future research directions (Briner and Denyer, 2012; Tranfield et al., 2003). The systematic narrative review approach, unlike meta-analysis and bibliometric reviews, is in particular suitable to this purpose for three reasons.

- Systematic narrative reviews are attractive when the body of knowledge becomes increasingly fragmented and transdisciplinary, as well as when it becomes complex - in particular to practitioners - to manage the diversity of knowledge for a specific academic inquiry (Tranfield et al., 2003).

- Narratives are at the heart of constructing new explanatory theoretical models and discovering new research directions based on summarizing, explaining and critical reflecting on the findings of multiple studies (Popay et al., 2006).

- Systematic narrative reviews are most suitable when multiple storylines exist, reflecting multiple scientific traditions within a research field and which tend to differ from each other with respect to: conceptualization of the topic; language and metaphors used; formulation of research questions; research methods applied as well as qualification used (for example to assess "quality" or "success"). This complicates statistical syntheses techniques (Greenhalgh et al., 2004; Greenhalgh et al., 2005).

A key strength of a systematic narrative review is the relative fine-grained content analysis constructing explanatory theoretical models unlike bibliometric reviews (Schraven et al., 2015; White and McCain, 1998b) and meta-analysis (Popay et al., 2006; Shadish, 1996). In contrast, narrative reviews are prone to reviewers bias relative to bibliometric reviews or meta-analysis.

The authors adhered to the principles and conduct of systematic review - organization, transparency and replicability to minimize the effect of reviewers' bias. This systematic narrative review follows the suggestions by Tranfield et al. (2003), Briner and Denyer (2012) and the 'diffusion of innovation' review by Greenhalgh et al. (2004) who conducted a systematic review regarding the diffusion of innovations in health service organisations. Therefore, our review followed the four stages of a systematic review: (1) planning; (2) searching; (3) screening; and (4) extracting and conducting a narrative synthesis (Briner and Denyer, 2012; Tranfield et al., 2003).

(1) Planning - The main question guiding our review is: 'which determinants affect the adoption of innovation in the context of housing projects?'.

(2) Searching - We first applied a search query based on the key words 'adoption', and 'housing' and used these keywords to search for relevant, empirical and peer-reviewed scientific journal articles in Clarivate Analytics' Web-of-Science (WoS) database. We selected the Web of Science database to conduct our review since it contains the top, high quality innovation journals. 
This ensures that we construct our conceptual model based on sound theoretical cornerstones derived from scientific articles published in these journals. As a robustness check, we also consulted the Scopus database applying the same keywords. Since several construction related journals are not included in the Web-of-Science or Scopus databases, we decided to complement the search process by searching for relevant scientific articles in the ARCOM database.

The ARCOM database hosts several influential scientific journals linked to the construction sector. Searching this database ensures that also context specific research articles are included in the review.

Subsequently, the search queries 'adoption' and 'housing' resulted in respectively 1,352 articles from the Web of Science database and 1,117 articles from the Scopus database, published in the timeframe between January 2008 until July 2019. Based on the search query 'adoption' another 336 articles were found in the ARCOM database. References from all selected studies were also cross-checked to identify additional relevant articles.

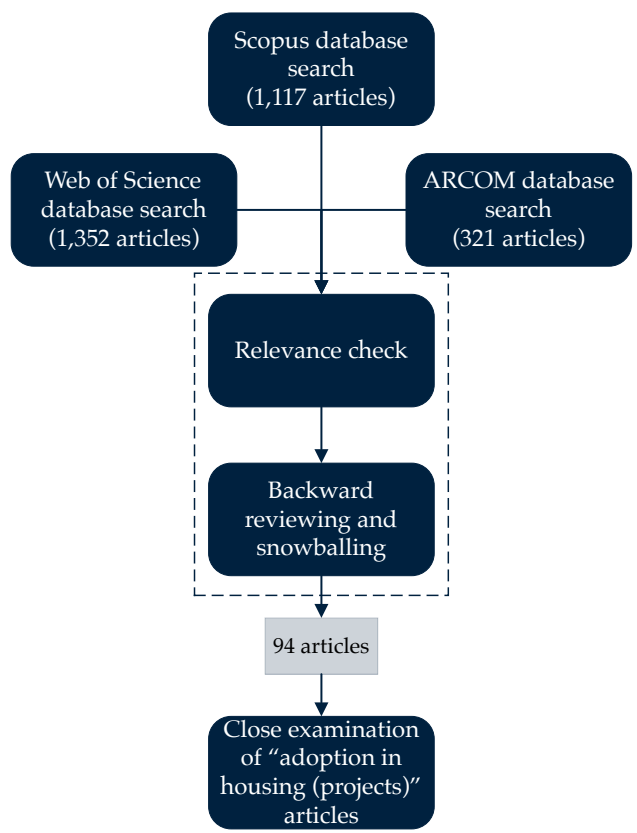

\footnotetext{
*The search queries "Adoption [AND] housing" resulted in 1,352 articles from the WoS database and 1,117 articles from the Scopus database respectively, published between 2008-June 2019. Based on the search query "adoption" another 321 articles were found in the ARCOM database.
}

Figure 3.1: Conceptual model of the systematic review 
(3) Screening - Articles were assessed based on explicit inclusion and exclusion criteria (see Appendix A Systematic Review Protocol) to ensure that each article in this study is relevant to the adoption-innovation domain in housing projects. Therefore the abstract, keywords and introduction section were manually evaluated by the authors. We also took into account that synonyms are applied to describe adoption like 'uptake' and '(user) acceptance'. Furthermore, some researchers used 'diffusion', 'dissemination', 'commercialization', 'implementation' or 'usage' to refer to adoption. These articles were also included in this review. Studies that match one of the following criteria were excluded because they do not primarily focus on innovation adoption in the housing sector:

- Studies that focus on 'implementation' and 'usage' instead of adoption;

- Studies that take social technical regimes shifts, technology transfer and market or industry transitions as focal point of analysis instead of the adoption and/or diffusion of innovation itself. Notwithstanding, papers which include the influence of determinants related to adoption are included in the review;

- Studies that aim to explain the commercialization and marketing of innovation;

- Studies with a focal point of analysis aimed at consumer adoption without taking into consideration the context of the housing industry (for example articles which address the adoption of PV by homeowners from an endogenous perspective without taking into account contextual determinants of the housing industry); and

- Feasibility studies that assess the potential merits or progress of diffusion of specific innovations.

A snowballing approach was used to complement the papers identified, because searching the WoS, Scopus and ARCOM databases is unlikely to identify all relevant articles (Briner and Denyer, 2012). In particular, backward and forward reviewing (Levy and Ellis, 2006; Webster and Watson, 2002) was used to identify the papers necessary to derive a richer and more complete understanding. In contrast to the suggestions of Briner and Denyer (2012) we decided not to include grey literature, industry reports and conference proceedings for several reasons. First, industry reports and scientific articles often duplicate each other's findings, e.g. compare for example the reports 'The Diffusion of Innovation in the Residential Building Industry' (Koebel et al., 2004) and 'Characteristics of Innovative Production Home Builders' (Koebel and Cavell, 2006) with the research articles published by Koebel (2008); Koebel et al. (2015).

Second, industry reports and conference proceedings tend to focus on the state-of-the-art and the potential of innovation rather than extensively identifying adoption mechanisms. Moreover, potential benefits of an innovation are often presented as adoption determinants without further evidence or clear explanation, e.g. reports published about Modern Methods of Construction (Corner et al., 2005; NHBC, 2016). 
Third, we also learned that only a few conference proceedings met our quality standards, i.e. these articles did not clearly specify the research question, lack a sound theoretical framework or suffer from methodological issues. Also, in several cases we could not check if the conference articles were evaluated by a double blind peer review process. Thus, scientific articles about innovation adoption in housing and published in double blind reviewed scientific journals were reviewed by the authors.

Because this review addresses the adoption of innovation in the housing sector, we further focused our closer examination on all the articles which passed the screening process. However, before extracting and synthesizing data we also conducted a quality check. To complete our quality check of the sample (Briner and Denyer, 2012; Tranfield et al., 2003), we assessed the research findings relative to the gap in literature and/or research question addressed in the articles. We considered all papers of sufficient quality to be included in the review, although from a methodological point of view it was not always clear how data was collected, processed and/or analysed. Table 3.3 presents an overview of the research methodologies applied studying innovation adoption in the housing sector.

(4) Extracting and synthesizing - We constructed a Data Extraction Form to guide the narrative synthesis. Following Popay et al. (2006) a narrative synthesis can be applied when exploring complex and discursive bodies of knowledge. Therefore, we used a narrative synthesis as a way to develop propositions and build them into a conceptual framework that provides nuanced insights about innovation adoption in housing projects. The conceptual framework and propositions bring together findings from a collection of studies to achieve a greater level of understanding, attain a level of theory development and which subsequently reveal new opportunities for future research.

\subsection{A Taxonomy of the adoption of innovation in housing literature}

The 94 identified articles about innovation adoption in the housing sector were published in 51 different scientific journals ranging from business economics (management, business and economics), environmental science to planning studies (construction). From the 94 articles included in our sample $62(66 \%)$ were published in a scientific journal with a Scientific Impact Factor (June 2018), see Table 3.1. Table 3.2 enlists the articles which have been cited at least more than 20 times. Table 3.3 provides an overview of the research methods applied to assess the adoption of innovation in housing. 
Table 3.1: Overview of scientific journals

\begin{tabular}{|c|c|c|}
\hline Journal & 2017 Impact factor & Number of articles \\
\hline Applied Energy & 7,900 & 3 \\
\hline Architectural Engineering and Design Management & $\mathrm{n} / \mathrm{a}$ & 1 \\
\hline Building and Environment & 4,539 & 1 \\
\hline Building Research \& Information & 3,468 & 7 \\
\hline Built Environment Project and Asset Management & $\mathrm{n} / \mathrm{a}$ & 1 \\
\hline Business Strategy and the Environment & 5,355 & 1 \\
\hline Cityscape: A Journal of Policy Development and Research & $\mathrm{n} / \mathrm{a}$ & 1 \\
\hline Construction Economics and Building & $\mathrm{n} / \mathrm{a}$ & 1 \\
\hline Construction Innovation & $\mathrm{n} / \mathrm{a}$ & 4 \\
\hline Construction Management and Economics & $\mathrm{n} / \mathrm{a}$ & 4 \\
\hline Energy and Buildings & 4,457 & 1 \\
\hline Energy Efficiency & 1,634 & 3 \\
\hline Energy Policy & 4,039 & 13 \\
\hline Engineering, Construction and Architectural Management & $\mathrm{n} / \mathrm{a}$ & 2 \\
\hline Environment, Development and Sustainability & 1,379 & 1 \\
\hline Forestry Chronicle & 0,488 & 1 \\
\hline Futures & 2,256 & 1 \\
\hline Habitat International & 3,000 & 3 \\
\hline Housing Studies & 1,639 & 2 \\
\hline International Journal of Building Pathology and Adaptation & $\mathrm{n} / \mathrm{a}$ & 1 \\
\hline International Journal of Built Environment and Sustainability & $\mathrm{n} / \mathrm{a}$ & 1 \\
\hline International Journal of Construction Education and Research & $\mathrm{n} / \mathrm{a}$ & 1 \\
\hline International Journal of Engineering \& Technology & $\mathrm{n} / \mathrm{a}$ & 1 \\
\hline International Journal of Environmental Research and Public Health & 2,145 & 1 \\
\hline International Journal of GEOMATE & $\mathrm{n} / \mathrm{a}$ & 1 \\
\hline International Journal of Low-Carbon Technologies & 0,837 & 1 \\
\hline International Journal of Organizational Innovation & $\mathrm{n} / \mathrm{a}$ & 1 \\
\hline International Journal of Sustainable Built Environment & $\mathrm{n} / \mathrm{a}$ & 1 \\
\hline Journal of Architectural Engineering & $\mathrm{n} / \mathrm{a}$ & 1 \\
\hline Journal of Cleaner Production & 5,651 & 3 \\
\hline Journal of Construction Engineering and Management & 2,201 & 3 \\
\hline Journal of Engineering Design and Technology & $\mathrm{n} / \mathrm{a}$ & 1 \\
\hline Journal of Engineering, Project and Production Management & $\mathrm{n} / \mathrm{a}$ & 1 \\
\hline Journal of Geography and Regional Planning & $\mathrm{n} / \mathrm{a}$ & 1 \\
\hline Journal of Green Building & $\mathrm{n} / \mathrm{a}$ & 3 \\
\hline Journal of Housing and the Built Environment & 1,329 & 2 \\
\hline Journal of Housing Economics & 0,811 & 1 \\
\hline Journal of Management in Engineering & 2,282 & 1 \\
\hline Journal of Sustainable Real Estate & $\mathrm{n} / \mathrm{a}$ & 1 \\
\hline Journal of the American Planning Association & 2,041 & 1 \\
\hline Malaysian Construction Research Journal & $\mathrm{n} / \mathrm{a}$ & 1 \\
\hline Open House International & 0,081 & 1 \\
\hline Scandinavian Journal of Forest Research & 1,600 & 1 \\
\hline Structural Survey & $\mathrm{n} / \mathrm{a}$ & 1 \\
\hline Sustainability & 2,075 & 4 \\
\hline Sustainable Cities and Society & 3,073 & 2 \\
\hline Technological Forecasting \& Social Change & 3,129 & 1 \\
\hline Technology Analyses \& Strategic Management & 1,49 & 1 \\
\hline The Bell Journal of Economics & $\mathrm{n} / \mathrm{a}$ & 1 \\
\hline Total Quality Management & 1,526 & 1 \\
\hline \multirow[t]{2}{*}{ Urban Water Journal } & 2,744 & 1 \\
\hline & Total number of articles & 94 \\
\hline
\end{tabular}


Table 3.2: Articles included in this review sample ( $n=94)$ which have been cited at least 20 times according to the Web of Science database. Out of the 94 articles included in our review, 21 articles are not include in the WoS database and thus lack a WoS citations count.

\begin{tabular}{|c|c|c|c|}
\hline$\#$ & Reference & $\begin{array}{l}\text { Citations } \\
\text { WoS }\end{array}$ & $\begin{array}{l}\text { Journal published, including Journal Impact Factor } \\
\text { (2017) }\end{array}$ \\
\hline 1 & Nair et al. (2010a) & 118 & Energy Policy $(4,039)$ \\
\hline 2 & Beerepoot and Beerepoot (2007) & 72 & Energy Policy $(4,039)$ \\
\hline 3 & Pan et al., (2008) & 55 & Building Research and Information $(3,468)$ \\
\hline 4 & Toole (1998) & 54 & Journal of Construction Engineering and Man. $(2,201)$ \\
\hline 5 & Berardi (2013) & 52 & Energy Policy $(4,039)$ \\
\hline 6 & Gan et al. (2015) & 52 & Habitat International $(3,000)$ \\
\hline 7 & Mlecnik et al. (2010) & 49 & Energy Policy $(4,039)$ \\
\hline 8 & Oster and Quigley (1977) & 49 & The Bell Journal of Economics (-) \\
\hline 9 & Achtnicht and Madlener (2014) & 45 & Energy Policy $(4,039)$ \\
\hline 10 & Nair et al. (2010b) & 41 & Applied Energy $(7,000)$ \\
\hline 11 & Crabree and Hes (2009) & 40 & Housing Studies $(1,639)$ \\
\hline 12 & Zhang et al. (2014) & 39 & Habitat International $(3,000)$ \\
\hline 13 & Pinkse and Domisse (2009) & 38 & Business Strat. and the Environment $(5,355)$ \\
\hline 14 & Ozorhon et al. (2014) & 36 & Journal of Management and Engineering $(2,282)$ \\
\hline 15 & Hoppe (2012) & 32 & Energy Policy $(4,039)$ \\
\hline 16 & Fawcett (2014) & 30 & Building Research and Information $(3,468)$ \\
\hline 17 & Dewick and Miozzo (2002) & 29 & Futures $(2,256)$ \\
\hline 18 & Haines and Mitchell (2014) & 26 & Building Research and Information $(3,468)$ \\
\hline 19 & Owen et al., (2014) & 25 & Energy Policy $(4,039)$ \\
\hline 20 & Tambach et al. (2010) & 24 & Energy Policy $(4,039)$ \\
\hline 21 & Blackley and Shepard (1996) & 23 & Journal of Housing Economics $(0,811)$ \\
\hline 22 & Koebel et al. (2015) & 23 & Energy and Buildings $(4,457)$ \\
\hline 23 & Lees and Sexton (2011) & 20 & Building Research and Information $(3,468)$ \\
\hline
\end{tabular}

Table 3.3: Research methodologies applied in articles included in the review sample (n=94)

\begin{tabular}{lc}
\hline Research methodology & Number of times applied (n=94) \\
\hline Conceptual / literature review & 6 \\
Qualitative methodologies including (multiple) case studies; interviews; & 35 \\
focus groups; job shadowing / observations & \\
Qualitative methodologies involving surveys & 34 \\
Mixed research methods & 10 \\
Methodologies applying secondary sources / data sets & 9 \\
\hline
\end{tabular}

For the purpose of this review we assessed the theoretical lenses that researchers applied to research the adoption of innovation in the housing sector (Table 3.4). Within our sample 40 articles applied socio-economic theories; 22 articles built upon Rogers' Diffusion of Innovations theory; 14 articles built on organizational behavioural theories and 10 articles could be linked to cognitive behavioural decision science respectively. We also identified 6 articles (Engström and Hedgren, 2012; Liu et al., 2018; Mlecnik, 2016; Ramli et al., 2019; Riala and Ilola, 2014; Toole, 1998) that built on several theoretical concepts. 
Surprisingly, we could not link 31 articles to any specific adoption theory. Several of these 31 articles built on previous research findings and were not clearly grounded in theory.

We eventually assessed the type of innovations that are considered for adoption in the housing sector. The innovations that were studied in these articles can be characterized as technological or administrative innovations (Daft, 1978; Damanpour, 1987; Kimberly and Evanisko, 1981). Within the category technological innovation, researchers took into account the adoption of sustainable technology, new construction materials and methods and industrial building. No more than 3 articles focused on the adoption of ICT as a primary unit of analysis (Kereri and Adamtey, 2019; Liu et al., 2018; van Egmond-de Wilde de Ligny and Mohammadi, 2011). As a next step, building on the framework of Henderson and Clark (1990), we distinct between incremental, modular, systemic and radical innovations (see Table 3.5). The few studies addressing the adoption of administrative innovations focused on the adoption of an alternative housing delivery system (Shafiei et al., 2010; Yusof and Mohd Shafiei, 2011) and sustainable (design) management (for example LEED) (Bowers et al., 2014; Mlecnik et al., 2010). These studies are not further considered in our review.

We were not able to identify a single radical innovation. This raises the question why this is the case. Housing and the construction industry in general have been classified as a traditional or low-tech industry and characterized by weak internal innovation capabilities and by strong dependencies on the external provision of machines, equipment and software (Heidenreich, 2009; Pavitt, 1984; Reichstein et al., 2008). In line with the sectorial typology of Pavitt (1984) and Utterback and Abernathy (1975), low-tech industries are characterized by mature and standardized processes that limit the possibilities of further product and process innovations. As a result cost optimization strategies dominate in contrast to innovation emanating from R\&D investments, which are often found economically not profitable (Greenhalgh and Rogers, 2006; Heidenreich, 2009). Innovations however do occur in low -tech industries. Supported by recent research about innovation in low-tech industries (Heidenreich, 2009; Hirsch-Kreinsen, 2008; Reichstein et al., 2005, 2008), innovation can take place without formal $R \& D$ and could be the result of incremental product improvements, customer-oriented developments or process optimisation strategies. The incremental and architectural innovations identified in this review have in common that they build upon given technologies which are continuously improved. All the modular innovations identified in this review were - not surprisingly - developed and introduced by suppliers from outside the housing sector. These modular innovations in particular include industrially produced building components (wall sections and floor slabs) and the adoption of new energy technologies. 
Table 3.4: Overview of theoretical concepts (TCs) applied (references in italic build upon several TCs)

Theoretical concept (TC) \# Reference

Socio-economic theories about innovation adoption (40 articles)

Sociotechnical transition theory

Diffusion of Innovations Theory

(Imperfect, asymmetric) information availability

(Unarticulated) tacit knowledge

Social learning theory

"Education for sustainability"

"Needs of the customer"

Change agents, opinion leaders, persona-based research, agency theory

Theory of Planned Behaviour / Technology Acceptance Model
4 (Brown et al., 2014) (Mlecnik, 2016) (Tambach et al., 2010) (van Egmond-de Wilde de Ligny and Mohammadi, 2011)

22 (Akinboade, 2012) (Blackley and Shepard III, 1996) (Egmond et al., 2006a) (Ganguly et al., 2010) (Koebel, 2008) (Koebel et al., 2015) (Lees and Sexton, 2014) (McCoy et al., 2012) (McCoy et al., 2015) (Mlecnik, 2010) (Mlecnik, 2016) (Mlecnik et al., 2010) (Nair et al., 2010a) (Nair et al., 2010b) (Nair et al., 2012) (Njuguna, 1997) (Ozorhon et al., 2013) (Ramli et al., 2019) (Riala and Ilola, 2014) (Sanderford et al., 2015) (Sanderford et al., 2018) (Toole, 1998)

2 (Duah and Syal, 2016) (Syal et al., 2013)

1 (Wolfe and Hendriks, 2011)

1 (Berry et al., 2014)

2 (Bossink, 2018) (Graham and Warren-Myers, 2019)

1 (Adinyira et al., 2018)

3 (Haines and Mitchell, 2014) (Muyingo, 2015) (Owen et al., 2014)

4 (Berardi, 2013) (Liu et al., 2018) (Ramli et al., 2019) (Steinhardt and Manley, 2016)

Organizational Behavioural Theory (14 articles)

Evolutionary economics

Institutional theory; isomorphism, innovation-regulation paradox; (national) systems of innovation

Organisational information-processing theory

Behavioural change

Readiness towards change

Dynamic capabilities framework
1 (Lees and Sexton, 2014)

7 (Beerepoot and Beerepoot, 2007) (Dewick and Miozzo, 2002) (Femenías et al., 2018) (Liu et al., 2018) (Lindgren and Emmitt, 2017) (Steinhardt et al., 2019) (Warren-Myers and Heywood, 2018)

2 (Engström and Hedgren, 2012) (Levander et al., 2011)

1 (Egmond et al., 2005)

2 (Yusof and Shafiei, 2011) (Yusof et al., 2010)

1 (Pinkse and Dommisse, 2009)

\section{Cognitive behavioural decision science (10 articles)}

Cognitive decision theory, decision-making bias

Motivation-Opportunity-Ability framework, willingness-to-pay

Concepts and models related to environment-related behaviour
6 (Christie et al., 2011) (Crabtree and Hes, 2009) (Hedgren and Stehn, 2014) (Engström and Hedgren, 2012) (Riala and Ilola, 2014) (Toole, 1998)

2 (Baumhof et al., 2018) (Tan et al., 2017)

2 (Boser and El-Gafy, 2011) (Hauge et al., 2013)

\section{Not specifically linked to any adoption theory (31 articles)}

Articles which could not linked to any specific theoretical framework in the field of innovation adoption
31 (Abdel-Wahab et al., 2011) (Achtnicht and Madlener, 2014) (Ali et al., 2018) (Azam Haron et al., 2015) (Bowers et al., 2014) (Boyd et al., 2012) (Daget and Zhang, 2018) (Fawcett, 2014) (Gan et al., 2015) (Hoicka and Parker, 2018) (Hoppe, 2012) (Im et al., 2017) (Kereri and Adamtey, 2019) (McCabe et al., 2018) (Mueller and Berker, 2013) (Nahmens and Reichel, 2013) (Ojoko et al., 2018) (Olsthoorn et al., 2019) (Oster and Quigley, 1977) (Pan and Cooper, 2011) (Pan et al., 2007) (Pan et al., 2008) (Parsons et al., 2010) (Roders and Straub, 2015) (Swan et al., 2017) (Swan et al., 2013a) (Swan et al., 2013b) (Xiahou et al., 2018) (Yang and Yang, 2015) (Akmam Syed Zakaria et al., 2018) (Zhang et al., 2014b) 
Table 3.5: A taxonomy of innovation types in the housing sector (based on the framework of Henderson and Clark, 1990). References can be found in Appendix $B$ a,b.

\section{COREC ONCEPT}

REINFORCED

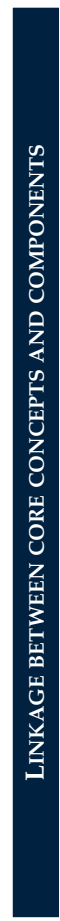

- Building equipment [69] waste building technologies [84][90]

- Industrial building

\section{INCREMENTALI NNOVATION \\ - (Green) building materials}

Such as: insulation materials; (energy efficient) doors $\mathcal{E}$ windows; composites [04][08][14][15][20][22][31][40][41] [48][55][56][57][61][62][70][71][85]

Such as: scaffolding, formwork, machinery

ARCHITECTURAL (SYSTEMIC) INNOVATION - Sustainable building concepts ${ }^{\mathrm{c}}$ Such as: high performance buildings (for example Passive House; LEED; Energy Label; Energy Star; CASBEE); energy 곤 efficient retrofitting (Passive House); low[02][06][07][10][13][17][18][19][23][24][25][28] $[30][33][34][49][50][51][52][60][74][75][82][83]$ [05][06][12][16][21][26][27][35][43][45][59][65] [66][76][77][78][89][93][94]

\section{OVERTURNED}

MODUlAR INNOVATION

Renewable energy technologies

Such as: PV systems; solar hot water systems; various HVAC systems (with heat recovery); heat pumps

[01][04][08][09][11][14][20][37][38][41][42][46] [53][62][64][68][73][79][80][81][87]

Water efficiency technologies [04][09][20][62][67][88]

Modular -factory-built- wall and floor panels

Such as: timber frame panels; (insulating) precast concrete; volumetric units [04][09][11][12][37][41][47][54] [63][69][85]

\section{RADICAL INNOVATION}

Not identified

Note:

a [03][32][58][72][83][91][92] include management innovations (building design techniques; strategies for climate adaptation measures; housing delivery system) which do not fit into the model

${ }^{b}$ Limited attention have been devoted to research the adoption of ICT innovation in the context of housing, including Radio Frequency Identification Devices (RFID) [39][44] and domotics [86]. These innovations do not fit within the framework.

c (Green) building materials include: low VOC painting [09]; eco-concrete [09]; environmentally certified wood products (FSC) [15][20][71]; insulated concrete wood and cement bricks [04]; wood-cement composite panels [04]; fiber cement exterior trim material [04][41]; fiber cement flooring underlayment [41]; wood I-joist as roof rafters [41]; wood/plastic composite decking lumber [04][41]; wood/plastic composite exterior trim/moulding [41]; spray-in foam insulation [41]; laminate flooring [41]; fiberglass doors [04][41]; OSB subflooring [41]; (Energy efficient) building envelope (including doors and windows and draught stripping), building envelope measures [38][56][57][58][62][80][81]; (triple) glazing [09][40][48]; natural thermal insulation materials (fiberglass blown behind mesh, cellulose blown behind mesh and cellulose blown-in, no mesh) [22][31]; non-metallic (chiefly plastic) sheathed cable for electrical wiring systems (instead of metal conduit) [61]; $2 x 3$ inch studs, (in combination with) 24 inch placement [61]; preassembled plumbing [61];interlocking brick system [70]; window and piping (PEX) \& thermostat technologies [73]; house wrap [85]; non-wood trim [85]; vinyl-clad or all-vinyl windows and siding [85]; plastic plumbing supply pipe [85]; steel studs [85]

${ }^{d}$ Renewable energy technologies include: solar photovoltaic systems [01][04][08][19][37][42][53][62][80][81]; solar hot water systems [04][08][09][11][42][62][68][80][81]; HVAC, decentral condenser boiler (combi-boiler, producing for hot water and space heating), heat recovery [04]08][09][11][37][38][41][42][80][81]; heat pump [01][08][09][37][41][42][62][64][68][80] [81]. Less frequently technologies include: wind and petrol driven rope water pumps [04]; radiant cooling/heating [09]; biomass systems [42][62][80][81]; micro combined heat and power [42][80][81]; wind power systems [42][80][81]; fuel cells [42]; smallscale hydroelectric systems [42]; micro hydro [62]

'Most articles refer to 'sustainable construction' without further specification of the innovations involved. For example, articles [23][24][25][82] address deep retrofitting toward energy efficient housing and articles [74][75][87] focus on sustainable 'high performance buildings' which only can be achieved by applying systemic innovations (for example applying passive house principles). From a complementarity perspective these innovations include both technological and management innovations (Tatum, 1987). 


\subsection{Mechanisms affecting the adoption of innovation in housing}

In this section we discuss the determinants affecting the adoption of innovation in the context of housing projects. First we explored what constitutes a specific adoption determinant and subsequently we present a proposition about how it affects adoption. Rogers' $(1962,2003)$ theory on innovation adoption, the Technology-Organization-Environment framework developed by Tornatzky and Fleischer (1990) and Brown's (1981) Framework on adopter behaviour were applied as a starting point to synthesize the adoption determinants derived from the 94 articles included in this review. The developed conceptual framework (see Figure 3.2) encompasses the drivers and inhibitors affecting the (intention to) adopt an innovation in the context of housing projects. This conceptual framework comprises four categories of determinants that are linked to three theoretical cornerstones found in innovation adoption research, i.e. socio-economic theory, organizational behavioural theory and cognitive behavioural decision science (van Oorschot et al., 2018).

In the following sections we will address the four categories of adoption determinants, i.e. product's characteristics and innovation attributes; adopter characteristics; industry characteristics; and influence of the environment.

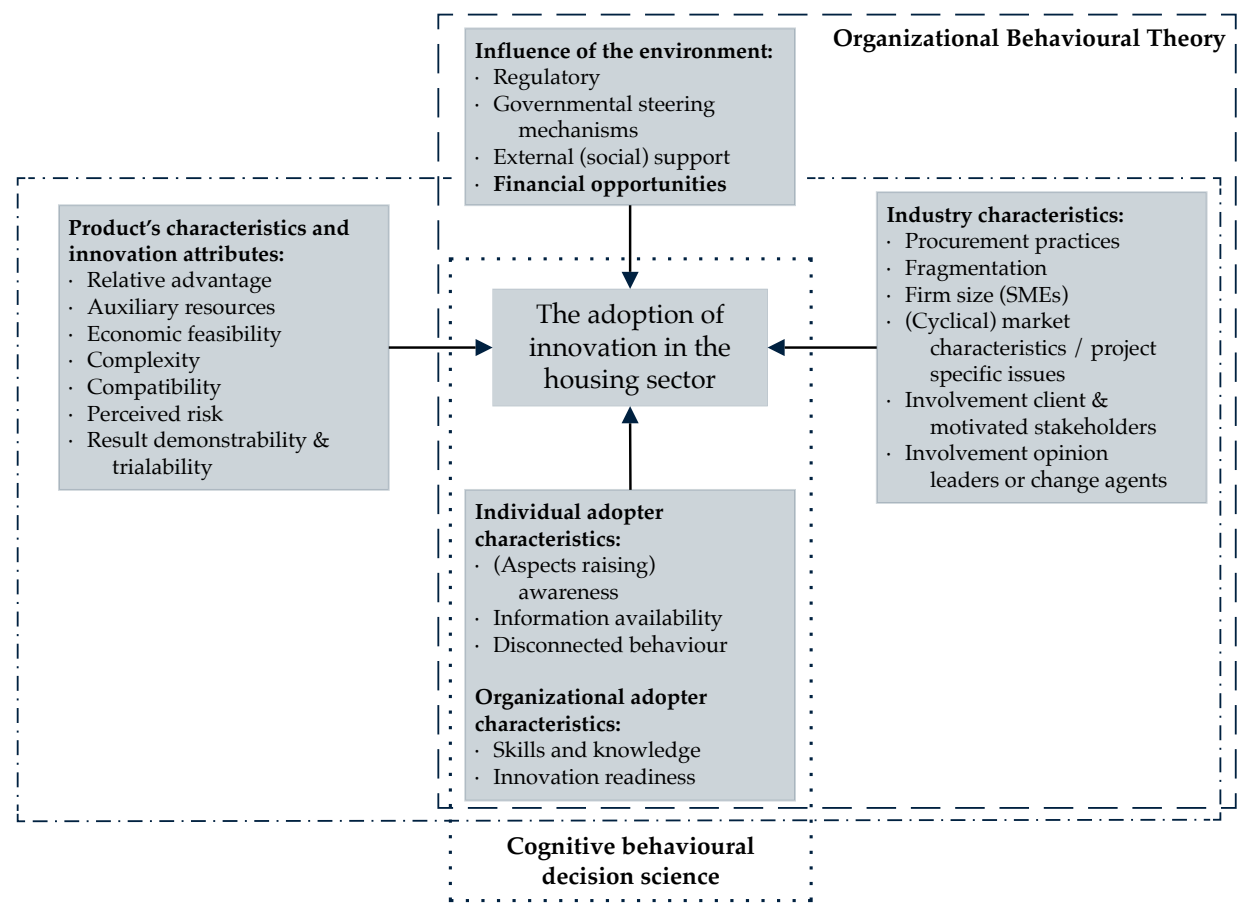

Figure 3.2: A conceptual framework of innovation adoption in the housing sector 


\subsubsection{Product's characteristics and innovation attributes}

In his seminal work, Rogers' (2003) found that the adoption of innovation can be explained by five perceived characteristics of innovation. These are: relative advantage; compatibility; complexity; trialability, and; observability. Construction innovation researchers also assessed the influence of these perceived characteristics on the adoption of innovation in the housing sector. First, they found that innovations should possess some form of relative advantage over alternatives (see Table 3.6) (McCoy et al., 2012; Mlecnik et al., 2010; Xiahou et al., 2018). In particular when homeowners are involved in the adoption decision-making process, the relative advantage should encompass immediate benefits such as comfort improvement or the replacement of particular building components due to their poor physical condition (Achtnicht and Madlener, 2014; Baumhof et al., 2018; Nair et al., 2010b; Roders and Straub, 2015; Swan et al., 2013b). The immaturity of an innovation (Gan et al., 2015; Zhang et al., 2014b) however, can have a detrimental effect on the perceived relative advantage and the decision to adopt the innovation.

\section{Table 3.6: Determinants of relative advantage in the context of housing}

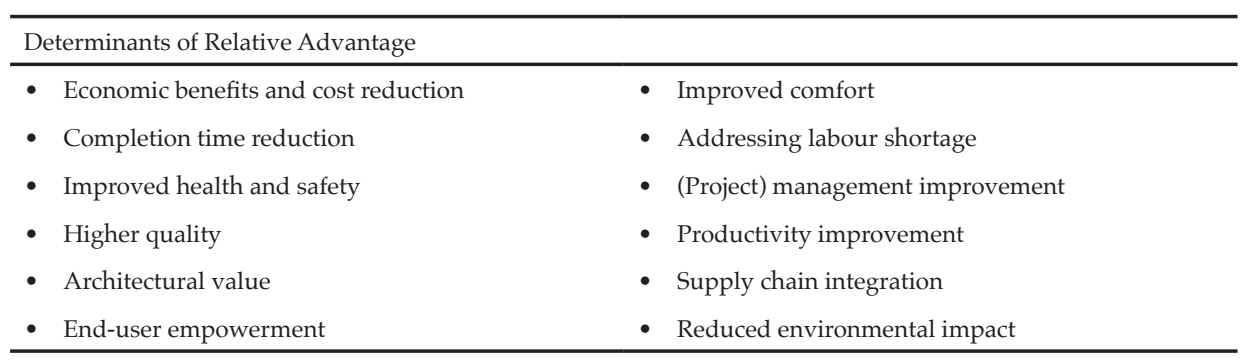

Second, evidence has been found for the influence of complexity (Nahmens and Reichel, 2013) and compatibility (Gan et al., 2015) on the adoption of innovation in the housing sector. Technological complexity and difficulties in using a new technology have a negative effect on adoption. The impact of the adversity of complexity increases when the application of the innovation highly depends on the availability of skilled personnel (Gan et al., 2015; Nahmens and Reichel, 2013; Zhang et al., 2014b) and the level of change to familiar construction processes (McCoy et al., 2012; Nahmens and Reichel, 2013). Also homeowners or tenants could perceive an innovation as complex. Researchers have identified a stepwise adoption as a key strategy to overcome the complexity inertia. Concerning the energy efficiency improvement of existing housing, it was found that a staged approach in contrast to an one-off integrated deep-renovation approach stimulates adoption of energy efficiency measures (Fawcett, 2014; Hoicka and Parker, 2018; Mlecnik, 2010).

Third, closely related to Rogers' compatibility, if the innovation requires to learn something new or change the way work is done (i.e. lack of interoperability and fit in existing supplier relations), it diminishes the propensity to adopt the innovation (Gan et al., 2015; Mlecnik et al., 2010). 
Fourth, evidence has been found that innovations also could benefit from result demonstrability and trialability (McCoy et al., 2012; Mlecnik et al., 2010; Mueller and Berker, 2013; Xiahou et al., 2018). Fifth, in conjunction with Rogers' perceived innovation characteristics, perceived risk is often found to affect adoption. Perceived risk concerning the impact of negative consequences for applying the innovation hinders the adoption of innovation (McCoy et al., 2012; Mlecnik et al., 2010). To summarize, this leads to the following five propositions:

\section{Proposition 1: Relative advantage}

The relative advantage of an innovation over alternatives has a positive effect on adoption. However the immaturity of the innovation has a negative effect on adoption and moderates the effect of relative advantage.

\section{Proposition 2: Complexity}

Complexity, emanating from a lack of skilled personal and the level of change to familiar construction practices, has a negative effect on adoption. Moreover, the complexity of the construction process in which the innovation needs to be incorporated - involving many stakeholders and interactions at multiple levels - has a negative effect on adoption.

\section{Proposition 3: Compatibility}

Lack of compatibility with existing construction processes (concerning the way work is done, the lack of interoperability and fit in existing supplier relations) has a negative effect on adoption of innovation.

\section{Proposition 4: Result demonstrability and trial-ability}

Result demonstrability and trial-ability have a positive effect on innovation adoption.

\section{Proposition 5: Perceived risk}

Perceived risk concerning the impact of negative consequences for applying the innovation has a negative effect on innovation adoption.

In addition to Rogers' perceived characteristics of an innovation, we identified two additional innovation determinants which are addressed in literature on innovation adoption in the housing sector. First, several researchers addressed the impact of auxiliary resources on innovation adoption. A wide range of resources have been identified which spur the uptake of innovation or when absent could hinder adoption, including assessment tools; standards and certification; governmental support; professional expertise and guidance; knowledge level availability and learning cycles; exemplary projects; understanding of (latent) client needs (Gan et al., 2015; Mlecnik, 2010; Mueller and Berker, 2013; Zhang et al., 2014b). Second, several variables have been found to influence adoption taking into account the economic feasibility of the innovation: investment costs; the payback period; time constraints to assess economic feasibility; energy costs; financial incentives (Gan et al., 2015; Zhang et al., 2014b). 
The perceived (poor) economic feasibility is considered one of the key determinants of innovation adoption in housing. To summarize, this leads to the following two propositions:

\section{Proposition 6: Auxiliary resources}

Auxiliary resources, consisting of assessment tools, standards and certification, governmental support, professional expertise and guidance, knowledge level, exemplary projects, understanding of (latent) client needs, support the adoption of innovation. In contrast, the absence of these resources hinders the adoption of innovation.

Proposition 7: Economic feasibility Economic feasibility issues concerning high investment cost, a relative long payback period and time constraints to assess the economic feasibility have a negative effect on the adoption of innovation. In contrast, (governmental) financial incentives have a positive effect on the adoption of innovation.

\subsubsection{Adopter characteristics}

Individual adoption characteristics. After the introduction of a classification of innovation adopters ranging from innovators to laggards (Rogers, 2003), studies have examined the intrinsic personal characteristics of individuals facing a decision to adopt a particular innovation. However, adopter characteristics (income, age, gender, education) only gained modest attention in the housing sector (Nair et al., 2010a, b; Nair et al., 2012). Behavioural characteristics like resistance (to change), aversion, (lack of) willingness and reluctance which are frequently mentioned in other sectors have only recently received more attention (Baumhof et al., 2018; Njuguna, 1997; Ozorhon et al., 2013; Tan et al., 2017). A particular personal characteristic which has been addressed by several researchers is the lack of awareness of the availability of new solutions and its economic benefits (Azam Haron et al., 2015; Bowers et al., 2014; Gan et al., 2015). Education and access to specific information create awareness and thus education and training could stimulate adoption (Oster and Quigley, 1977). However, typical for a low-cost and supply-driven industry culture, a lack of market demand and a lack of market orientation diminishes awareness, have a negative effect on adoption (Bowers et al., 2014; Gan et al., 2015; Nahmens and Reichel, 2013).

Besides that education and access to specific information create awareness about possible innovations, it also provides the knowledge base and skills to decide whether to adopt these innovations. In this respect previous experiences positively stimulate the adoption of innovation (Bowers et al., 2014; Sasatani et al., 2015). As has been emphasized in general adoption theory, information is key to the adoption and diffusion of innovation (Oster and Quigley, 1977; Rogers, 2003; Toole, 1998). In the context of the housing sector it has been found that imperfect and asymmetric information have a negative effect on adoption (Duah and Syal, 2016; Syal et al., 2013). This not only links to the decision whether to adopt an innovation but also to the information required to apply and/or operate the innovation; thus continued adoption highly depends on adequate hand-over and 'social learning' (Berry et al., 2014; Brown et al., 2014; McCabe et al., 2018; Swan et al., 2017; Swan et al., 2013a; Swan et al., 2013b). 
To summarize, this leads to the following two propositions:

Proposition 8: (Aspects raising) awareness

Thelack ofawareness (knowledgedissemination) ofaninnovation has anegativeeffectonadoption.

Proposition 9: Information availability

Imperfect and asymmetric information availability have a negative effect on the adoption of innovation. Moreover, poor information processing capabilities have a negative effect on innovation adoption.

Adoption research builds upon the assumption that adoption follows from a rational decision-making process (Rogers, 2003). Christie et al. (2011) for example addressed the nature of decision-making by individual decision making in housing projects, i.e. homeowners. These researchers introduced the concept of 'apparent disconnect': sustainable related considerations are taken into account and valued positively and still sustainable innovations are rejected. Thus, although innovations rationally are considered valuable, bias against these innovations inhibits its adoption. Christie et al. build upon the concepts of bounded rationality (Simon, 1957, 1991), loss aversion (Kahneman et al., 1991) and regret avoidance (Samuelson and Zeckhauser, 1988) to explain disconnected behaviour. The majority $(79 \%)$ of the homeowners involved in their research project showed 'disconnected behaviour' indicating that they want the technology but are not willing to pay for it.

Researchers also revealed that, in the case of adoption in housing, incumbent frames of reference and the information infrastructure on which it is based are not sufficient to guide decision making about an innovation. An experience-based, mechanistic form of decision-making has proven to create bias against the innovation (Engström and Hedgren, 2012; Hedgren and Stehn, 2014; Levander et al., 2011). This leads to the following proposition:

Proposition 10: Disconnected behaviour

Bias of the decision maker against an innovation - emerging from an incumbent frame of reference; risk avoidance behaviour; framing and aversion to change - has a negative effect on its adoption.

Organizational adoption characteristics. Many adoption decisions involve individuals employed by an organization. Researchers therefore assessed the motivation and innovative culture of firms active in the housing sector and its effect on adoption. Motivation and the innovation culture refer to the ability and willingness of an organization to adopt and implement an innovation (Yusof et al., 2010; Yusof and Mohd Shafiei, 2011), i.e. reflecting the readiness or innovation capability maturity of the organization (Pinkse and Dommisse, 2009).

First of all, market readiness variables, including (a) market responsiveness - looking for new ideas from the market and (b) market orientation - meeting the needs of clients as main goal, have a positive effect on adoption (Yusof et al., 2010; Yusof and Mohd Shafiei, 2011). 
Second, organizational readiness variables reflect the innovative culture of the firm. Expressed by policy guidelines, policy plans and action plans on certain issues, organizational readiness overall has a positive effect on adoption (Egmond et al., 2005; Roders and Straub, 2015; Swan et al., 2017; Swan et al., 2013b). In addition to this finding a risk taking culture (Pan et al., 2007; Pinkse and Dommisse, 2009) and self-efficacy (perception of its own capacity) (Egmond et al., 2005) has a positive effect on adoption. In contrast to the positive effect of these organizational readiness variables organizational bias and negativism, which relate to overemphasizing negative characteristics of the innovation, have a negative effect on adoption (Pinkse and Dommisse, 2009; Riala and Ilola, 2014). The split-incentive problem, another aspect of organizational readiness also undermines the willingness to adopt. The split-incentive problem occurs when, for example, the costs of adopting the innovation are for the contractor whereas the buyers benefit from the merits (Pinkse and Dommisse, 2009).

Third, resource readiness, in particular concerning information gathering capabilities and appropriate technical capacity and knowhow have a positive effect on adoption. Capabilities concerning communication are also most relevant considering the difficulties of communicating the merits of the innovation to other stakeholders in the project as well as client and/or end-users. Overall, various professional skills and knowledge have been emphasized to be an important determinant of innovation adoption (Pinkse and Dommisse, 2009; Yusof et al., 2010; Yusof and Mohd Shafiei, 2011).

Fourth, lack of data, tools and/or knowledge to convey the benefits to other stakeholders hinders the adoption of innovation (Crabtree and Hes, 2009). This is further complicated by the nature of the information which often involves tacit knowledge (Duah and Syal, 2016; Syal et al., 2013; Wolfe and Hendriks, 2011). Pinkse and Dommisse (2009) found that communicating the advantages of sustainable technologies to potential home buyers in order to create market demand remains a major challenge to contractors. It has proven difficult for a contractor to evaluate and next communicate about innovations because of the complex interactions among the various stakeholders. This seems particularly challenging when the innovation is considered risky and requires to break out the technological lockin. This leads to the following two propositions:

Proposition 11: Skills and knowledge

Previous experiences and education and training, contributing to the necessary skills and knowledge, have a positive effect on innovation adoption.

Proposition 12: Innovation readiness

A firm's readiness to adopt an innovation, comprising of market-; organizational-; resource readiness, and; knowledge to convey the benefits of an innovation, has a positive effect on adoption. 


\subsubsection{Industry characteristics}

Adoption researchers have reported about the importance to take into account the effect of contextual determinants such as the industry structure and the technological characteristics (Attewell, 1992; Brown, 1981; Downs and Mohr, 1976; Tornatzky et al., 1990). Many innovations are adopted in housing projects involving multiple project stakeholders. Within housing projects the following determinants affect the adoption of innovation: involvement of clients and motivated stakeholders, involvement of opinion leaders or change agents, fragmentation, procurement practices and market characteristics.

Several researchers have assessed the influence of stakeholders on adoption. Specifically the role of clients and occupants with respect to innovation adoption have been assessed (Hauge et al., 2013; Hoppe, 2012). Professional clients such as volume builders or social housing associations are named as potential change agents. They not only supply housing to consumers but also generate demand from the supply chain (Warren-Myers and Heywood, 2018). Although it is agreed that the involvement of professional clients like housing associations could spur innovation in housing, without the support of occupants the innovation could still be rejected, referred to as the principal-agent inertia. The principal-agent inertia reflects that end-users, people who are mostly affected by whether an innovation will be adopted, are not directly involved in the decision-making process. Thus, adoption depends on a decision of 'agents', representatives of social housing associations, housing co-operations and volume builders, to adopt a particular innovation. Poor end-user engagement and discarding the voice of the customer could result in an adoption decision which deviates from end-user(s) demand and subsequently hindering the adoption of innovation (see Table 3.7) (Azam Haron et al., 2015; Brown et al., 2014; McCabe et al., 2018; Muyingo, 2015).

Table 3.7: Determinants of the principal-agent inertia

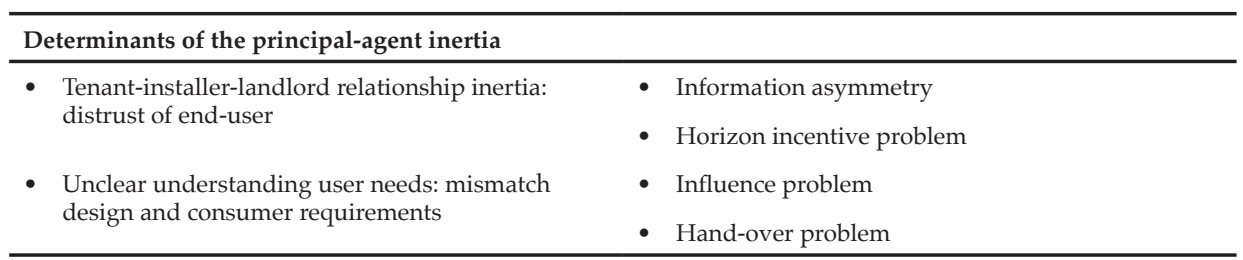

Owen et al. (2014) and Nair et al. (2012) have considered the positive influence of a largely overlooked change agent, namely energy technology installers and advisors, on the adoption of energy technology in residential retrofit projects. The empirical findings indicate that advisors and installers play a powerful role in influencing both the adoption and use of energy efficiency technologies. This leads to the following proposition:

Proposition 13: Client Involvement, motivated stakeholders and change agents The early involvement of clients/end-users and highly motivated (project) stakeholders have a positive effect on innovation adoption. In the same respect, the early involvement of change agents have a positive effect on innovation adoption. 
Many innovations in the housing sector will be adopted at the project level. Not surprisingly, it was found that the instability and fragmentation of temporary aggregations of many stakeholders in construction projects are barriers to adopting innovation. Fragmentation within the housing sector hinders adoption because of the complex interactions among the various stakeholders involved. Poor supply chain integration and cooperation affects adoption by:

- Insufficient coordination and collaboration within the supply chain which negatively affect adoption (McCoy et al., 2012; Wolfe and Hendriks, 2011);

- Late introduction of the innovation, subsequently resulting in the late involvement of key stakeholders, negatively affect adoption (Berardi, 2013; Hoppe, 2012; McCoy et al., 2012); and

- Structural barriers emanating from temporary project aggregations and a lack of partnering concept (i.e. loss of control, distrust, incomplete information and insufficient communication) negatively affect adoption (Berardi, 2013; Gan et al., 2015; Hoppe, 2012). Hoppe (2012) and McCabe et al. (2018) found that where a breakdown of communication between stakeholders occurred, there was also a breakdown in trust which is not conductive to innovation.

This leads to the following proposition:

Proposition 14: Fragmentation

Poor coordination within the fragmented housing sector - reflecting loose couplings within and across construction firms - hinders the adoption of innovation beyond single projects.

Characteristic to a fragmented industry, the housing sector largely consists of small and medium enterprises (SMEs). It has been found that firm size, measured by construction revenues and / or the number of employees and reflecting the available economic and information resources, affect the propensity to adopt innovations in housing (Yusof et al., 2010; Yusof and Mohd Shafiei, 2011). For example, Ganguly et al. (2010) found that large firms are more likely to adopt innovative building materials. Large firms continue the application of established building materials while slowly increasing use of the innovative counterpart. In contrast, when SMEs do adopt the same innovative insulation materials it replaces the traditional materials at a faster rate.

Thus, SMEs differ from large firms with respect to adoption timing and the level of adoption of an innovation (Blackley and Shepard III, 1996; Oster and Quigley, 1977). This leads to the following proposition:

Proposition 15: Firm size

The small firm size of construction SMEs has a negative effect on innovation adoption. 
Traditional project procurement practices, i.e. projects awarded to the lowest bid, are considered a critical barrier to adoption. Traditional procurement appears not conductive to overcoming the disadvantages (lack of trust, low level of cooperation, lack of information and communication) of fragmentation and loose network ties (Gan et al., 2015). Warren-Meyers and Heywood (2018) found that integrated procurement practices, such as Design and Construct, in line with a supporting supply chain, stimulate the adoption of (sustainable) innovation in housing.

In addition to effect of traditional low-cost oriented procurement, several determinants related to the construction process of housing projects were found to hinder adoption, including the time of introduction and the delay at which interest emerges; project deadlines and delays; and organization of the process (Hauge et al., 2013; Hoppe, 2012; McCoy et al., 2012). An example of traditional construction practices hindering adoption is provided by Berardi (2013) who found that the uptake of energy-saving technologies is slowed down by the late involvement of key stakeholders with the greatest interest (often the occupants). Consequently, most of the choices related to construction are made by stakeholders with low motivation for the adoption of energy-saving technologies and high power to impose their will. Hoppe (2012) also found that over-ambitious project goals and poor experiences in previous projects hinder the adoption of innovations.

This leads to the following proposition:

Proposition 16: Procurement practices

Traditional procurement and lowest price orientation are not conductive to overcoming the disadvantages of fragmentation and loose network ties and have a negative effect on innovation adoption. Next, (b) the construction process organization (i.e. the time of introduction and the delay at which interest emerges, project deadlines and delays, and organization of the process) has a negative effect on innovation adoption.

Several researchers claim that the cyclical nature of the housing sector caused by regular downturns, and resulting in uncertainties in market outlook, hinders the adoption of innovation (Blackley and Shepard III, 1996; Nahmens and Reichel, 2013). Several other economic determinants, related to project(-site) conditions, affect the adoption of innovation in housing. The propensity to adopt innovations varies directly with an increase in the price of the houses being constructed; innovations are more likely being adopted in the high-end market, consisting of larger and higher priced dwellings, in contrast to low-end markets (social housing).

The nature of the construction project, i.e. new build versus renovation, building typology and conventional versus industrialized construction also shape the conditions to apply an innovation (Blackley and Shepard III, 1996; Ganguly et al., 2010). These aspects refer to project specific issues which could affect the adoption of innovation in projects (see Table 3.8). A notable example is the poor accessibility of a construction site which hinders the application of large volumetric building modules. 
This leads to the following proposition:

Proposition 17: (Cyclical) market conditions and project specific issues:

Cyclical market conditions (regular downturns) have a negative effect on innovation adoption. In addition, project(-site) specific issues (low-end market segment, housing typology, site conditions) have a negative effect on adoption.

Table 3.8: Project(-site) specific issues affecting innovation adoption in housing

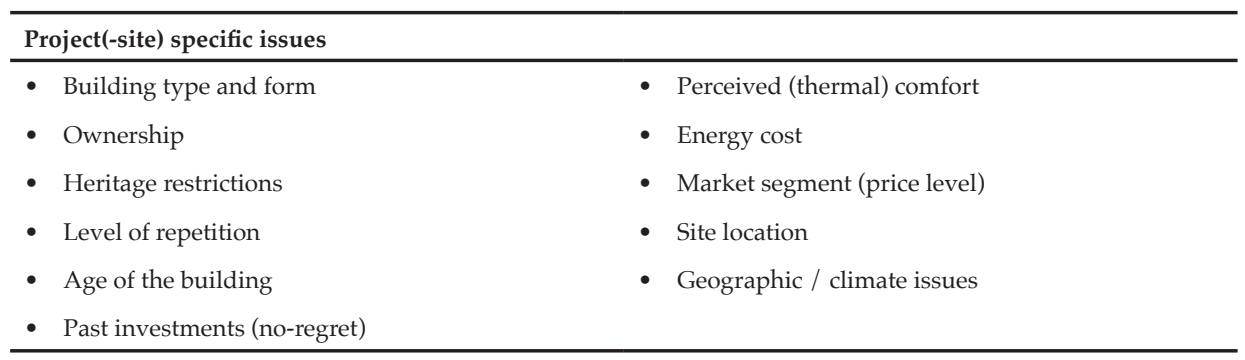

To summarize, fragmentation, lowest bid project procurement practices, project specific issues and market uncertainties are considered detrimental to the adoption of innovations in the housing sector. Several researchers therefore refer to 'contextual difficulties' or 'structural barriers' hindering the adoption of innovation in construction. In contrast to the importance of contextual difficulties we found that many research projects lack an adequate link to the context in which adoption decision-making takes place. This is supported by adoption research conducted in other parts of the construction sector (Larsen, 2011; Mukherjee and Muga, 2010).

\subsubsection{Influences of the environment}

Adoption behaviour of stakeholders in the housing sector is also affected by environmental forces. These include regulatory, financial opportunities and social support.

One form of institutional pressure often addressed concerning the adoption of innovation in the housing sector is the effect of building regulations. In particular the European Energy Performance of Buildings Directive (EPBD) and national sustainable construction agendas have been taken as focal point of analysis (Mlecnik et al., 2010). The main question is how and to what extent policy instruments and regulation effect innovation and innovation adoption. This research fits within a larger debate about regulation, competition and innovation (Dorée et al., 2003), also referred to as the innovation-regulation paradox (Dewick and Miozzo, 2002). Contradicting findings have been presented; some researchers claim that building regulations inhibit adoption where others just found the opposite (Beerepoot and Beerepoot, 2007; Gan et al., 2015; Mlecnik et al., 2010; Oster and Quigley, 1977). 
However it is generally accepted that it will be more likely that an innovation will be adopted when legislation and regulations are in place (Beerepoot and Beerepoot, 2007; Gan et al., 2015). This leads to the following proposition:

Proposition 18: Regulatory

Building regulations have a coercive and positive effect on innovation adoption.

Governmental steering mechanisms like legal support and permit procedures, governmental policy implementation effort, efficient monitoring systems and grants enhance the potential adoption of innovations in housing (Gan et al., 2015; Swan et al., 2013a; Tambach et al., 2010). Typical to innovation in low-tech industries such as housing, innovations tend to be developed upstream by component manufactures and need to be adopted downstream by contractors and the involved project stakeholders (Miozzo and Dewick, 2002; Pries and Janszen, 1995). Therefore, when applied in the wrong way and targeting the wrong stakeholders in the value chain, governmental steering mechanisms do not stimulate innovation and even could hinder the adoption of innovation (Beerepoot and Beerepoot, 2007; Koebel et al., 2015). This leads to the following proposition:

Proposition 19: Governmental steering mechanisms

Governmental steering mechanisms (i.e. legal support and permit procedures, governmental policy implementation effort, efficient monitoring systems and grants) have a positive effect on innovation adoption.

However, as emphasized by institutional theory, the effect of government influence should not be exaggerated (Vermeulen et al., 2007). It was found that without the legitimacy provided by construction firms, unions, interest groups and consumers adoption can become problematic (Gan et al., 2015; Oster and Quigley, 1977). For example, Egmond et al. $(2005,2006 \mathrm{a})$ found that energy-relevant behaviour of housing associations to a large extent depends on institutional forces, including subjective norm, feedback of peer organizations and feedback from authorities. The subjective norm of an organization refers to the strength of the opinions and feedback of other (governmental) organizations about the appropriateness of adopting a particular innovation.

In terms of external adoption drivers it has further being emphasized that for many innovations the support from financial institutions is required to cover the upfront (investment) costs (Gan et al., 2015; Yusof et al., 2010; Yusof and Mohd Shafiei, 2011). Innovative and alternate financing options - which normally need to be approved by the authorities - including lease contracts, community financing and subsidies, are considered essential to stimulate adoption (McCabe et al., 2018).

To summarize, external support, including client demand, subjective norm, feedback of peer organizations, feedback of authorities, regulations and facilitating and encouraging policy instruments (covenants, information, benchmarks and demonstration) have a positive effect on adoption (Egmond et al., 2005, 2006a; Pinkse and Dommisse, 2009; 
Yusof et al., 2010; Yusof and Mohd Shafiei, 2011). The external support should further be complemented by financial instruments to appropriate upfront investments. This leads to the following two propositions:

Proposition 20: External support

External support, reflecting strength of the opinions and feedback of other (governmental) organizations, has a positive effect on innovation adoption.

Proposition 21: Financial opportunities

Support from financial institutions to cover the investment cost has a positive effect on innovation adoption.

\subsubsection{Determinants of innovation adoption in the housing sector}

The determinants identified in this review link to 21 propositions that affect the adoption of innovation in the housing sector. Some of these propositions have a negative effect on adoption and are considered as barriers for innovation adoption, whereas propositions with a positive effect stimulate innovation adoption and subsequently diffusion. This indication is based on whether the articles included in our sample have identified the involved determinants as drivers (+) or barriers (-) to innovation adoption. Figure 3.3 presents an overview of the propositions and their effect on adoption.

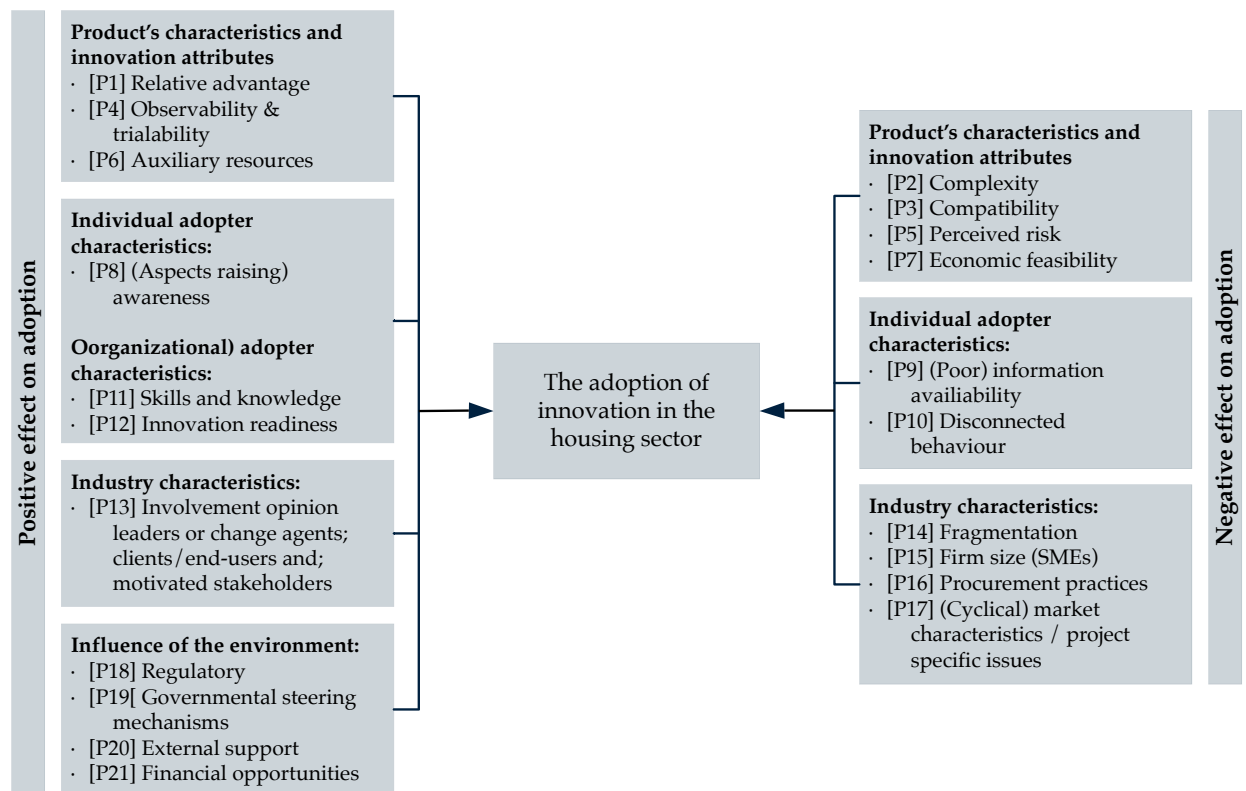

Figure 3.3: A coherent framework of positive and negative effects on innovation adoption in the housing sector 


\subsubsection{Major research results}

This study has produced the following major research results. First, this paper opened with a taxonomy of innovations. Building upon the framework of Henderson and Clark (1990) we were able to identify three types of innovation, i.e. incremental, modular and systemic innovations. We did not identify in the selected literature any radical, discontinuous innovations. This result agrees with the theory about innovation in low-tech sectors in which firms apply business strategies driven by cost optimization rather than innovation (Greenhalgh and Rogers, 2006; Heidenreich, 2009).

Second, there have been no attempts in the literature to identify and synthesize the different variables affecting the adoption of innovation in the housing sector to date. One of the primary contributions of this paper is that it has synthesized existing literature about innovation adoption in housing projects. The conceptual framework developed in this review comprises four categories of determinants and their underlying variables which affect the adoption of technology innovation in housing projects. The four categories of determinants are as follows: influence of the environment; product's characteristics and innovation attributes; industry characteristics and; individual adopter characteristics.

Third, based on the literature review 21 propositions were constructed that describe the key mechanisms by which the potential decision to adopt an innovation in a housing project is affected. As such the conceptual framework together with the 21 propositions provide an integrated view about what is known concerning the mechanisms affecting innovation adoption in housing projects.

The literature review further revealed that the most influential articles specifically researched the adoption of technological innovations in the field of sustainable housing or in the field of industrial house building. These technological innovations can be linked to the current debate about the high environmental impact, the poor quality and low efficiency of house building.

\subsubsection{Policy implications}

The conceptual innovation adoption framework that has been developed in this paper can serve as a tool to inform policy-makers to develop policies which could stimulate the adoption of particular innovations. For at least three adoption barriers, i.e. perceived risk (Proposition 5), financial feasibility (Proposition 7) and knowledge availability (Proposition 9), the government could play an important role as change agent, policy maker or knowledge broker by providing coercive regulation, financial incentives and knowledge infrastructure. 
For example, the European Parliament introduced the Energy Performance of Buildings Directive, Directive 2010/31 / EU, which stimulated the adoption of energy efficiency technologies. In the past governments have developed different types of financial incentives to appropriate the adoption and uptake of energy efficiency technologies such as heat pumps and solar panels.

\subsubsection{Implications for practitioners}

For practitioners, the findings of this research indicate which mechanism affect the adoption of a particular technological innovation in house building. In particular because the 21 propositions developed in our review are identified as critical prerequisites to adoption. In line with previous conducted reviews in the field of innovation management studies and organizational learning theory, we suggest that innovation managers attempt to test our propositions in practice (Slater et al., 2014; Taylor et al., 2010). Practice-based testing may improve insights about the adoption potential of an innovation when introduced in the market. Having this information can help in guiding the development strategy of innovations. For example by developing instruments to convey the benefits of a technological innovation to its potential beneficiary (Crabtree and Hes, 2009) or solving compatibility issues with respect to interoperability issues with traditional practices and the mismatch with existing supplier relations (Gan et al., 2015; Mlecnik et al., 2010). Thus, a comprehensive framework should enable managers to take into account the full range of determinants affecting the adoption potential of an innovation. Having said this, managers need to be willing and able to implement this practice-based strategy.

\subsubsection{Limitations in the selected innovation adoption literature and of the review method}

With respect to the innovation adoption literature that we have selected for this review, some critical observations can be made. First, the 94 articles included in this literature review, can to a significant extant be characterised as explorative. The selected research papers also appeared difficult to be coupled to each other. From the references that were provided in the respective papers we observed in many cases that no citations were made to other relevant papers. We were further surprised to find out that in our sample of 94 articles, 31 articles could not be linked to adoption theory and that only 22 articles were built upon Rogers' (2003) seminal work. It is often implicitly noticed in literature that (the adoption of) innovation in the housing sector can be challenging (Blayse and Manley, 2004; Bossink, 2004; Gambatese and Hallowell, 2011b; Gann and Salter, 2000; Reichstein et al., 2005, 2008; Winch, 1998). However, most articles in our literature selection lack a clear explanation why this is the case or why general adoption theories do not apply to housing. 
Moreover, the review method that we applied is not free of its limitations. Although we followed a narrative systematic review protocol as suggested by Tranfield et al. (2003) and Briner and Denyel (2012), this review is not entirely free of reviewers' bias such as the negative effect of pre-existing beliefs. Next, many researchers applied synonyms for 'adoption' or refer to adoption applying different terms like for example acceptance, usage, implementation, or diffusion. This made it in particular challenging to identify relevant articles while relevant articles could be easily missed.

\subsubsection{Agenda for future research}

This review provides a solid base for the development of a parsimonious, middle-range theory of innovation adoption (Campbell et al., 2003; Wisdom et al., 2014; Wong et al., 2010). The authors identified five lines of inquiry to be explored in the future.

First, because the number of variables included in our conceptual framework is high, we suggest therefore identifying critical variables by uncovering causal logic during case studies (Eisenhardt, 1989).

Second, quantitative research could contribute to our understanding of the effect of the adoption variables by assessing the causal effect of the variables determinants on the adoption of innovation. This line of research is further supported by methodological issues found in several articles in our dataset, i.e. it was not always clear how data was collected, processed and/or analysed by the authors.

The third line of inquiry contributes to the generalizability of the conceptual framework, including the 21 propositions developed in our review. The articles included in this review predominately researched the adoption of technological innovations in the housing sector. Therefore it is expected that the framework poorly explains the adoption of other types of innovations like management and service innovations. Moreover, one could wonder if the conceptual framework is applicable beyond housing, for example, within other sectors in construction like infrastructure and commercial and community buildings.

Next, the decision to adopt innovation in housing projects, involves multiple interrelated variables. As a result, future research should take into account the 'system dynamics' of interrelated adoption variables (Tan et al., 2017). Applying conceptual maps could advance research into innovation adoption in housing. These conceptual maps should include three types of interconnectedness: the interrelation between adoption variables; the interrelation between adopter and adoption variables, and; the interrelation between innovation type and adoption variables (Elazouni et al., 2005; Rosales-Carreón and GarcíaDíaz, 2015; Sexton and Barrett, 2005).

Finally, what can be deduced from literature is that adoption is constituted by multiple adoption decisions at the individual, project, organizational or industry level. This reflects 
that most innovations are not adopted at the level of a single organization (by a single individual) but at the level of inter-organizational projects. Thus the diffusion of a technological innovation depends on its subsequent adoption at the organizational and industry level across projects (Bygballe and Ingemansson, 2014; Dubois and Gadde, 2000, 2002; Winch, 1998; Xue et al., 2014). To summarize, it is hypothesized that the adoption of a technological innovation depends on multiple adoption decisions, each affected by a different sub-set of innovation adoption variables. This could be subject to future research to better grasp how adoption decisions of innovation in housing projects are taken.

\subsection{Conclusion}

The principal contribution of this review is to offer a new conceptual perspective on the determinants that affect the adoption of innovation in housing projects. This paper contributes to the innovation literature in three ways. First, building upon the framework of Henderson and Clark (1990) and an extensive literature review about innovations being adopted in the housing sector, we were able to categorize the innovations in the housing sector into three types of innovation: incremental, modular and architectural. The most important innovations in housing projects that have been reported so far in literature, are related to energy efficient housing and industrial house building. This review also revealed that house building lacks radical, disruptive innovations which is characteristic for traditional low tech industries (Pavitt, 1984; Utterback and Abernathy, 1975). Low-tech industry practices provide limited possibilities of further product and process innovations and as a result cost optimization dominate in contrast to innovation strategies (Greenhalgh and Rogers, 2006; Heidenreich, 2009). Second, this study is the first in which the various innovation adoption mechanisms for housing projects are integrated in a coherent innovation adoption framework. Third, it provides and underpins 21 propositions which reflect the state of knowledge about the mechanisms that effect the possible adoption of innovations in the housing sector. 



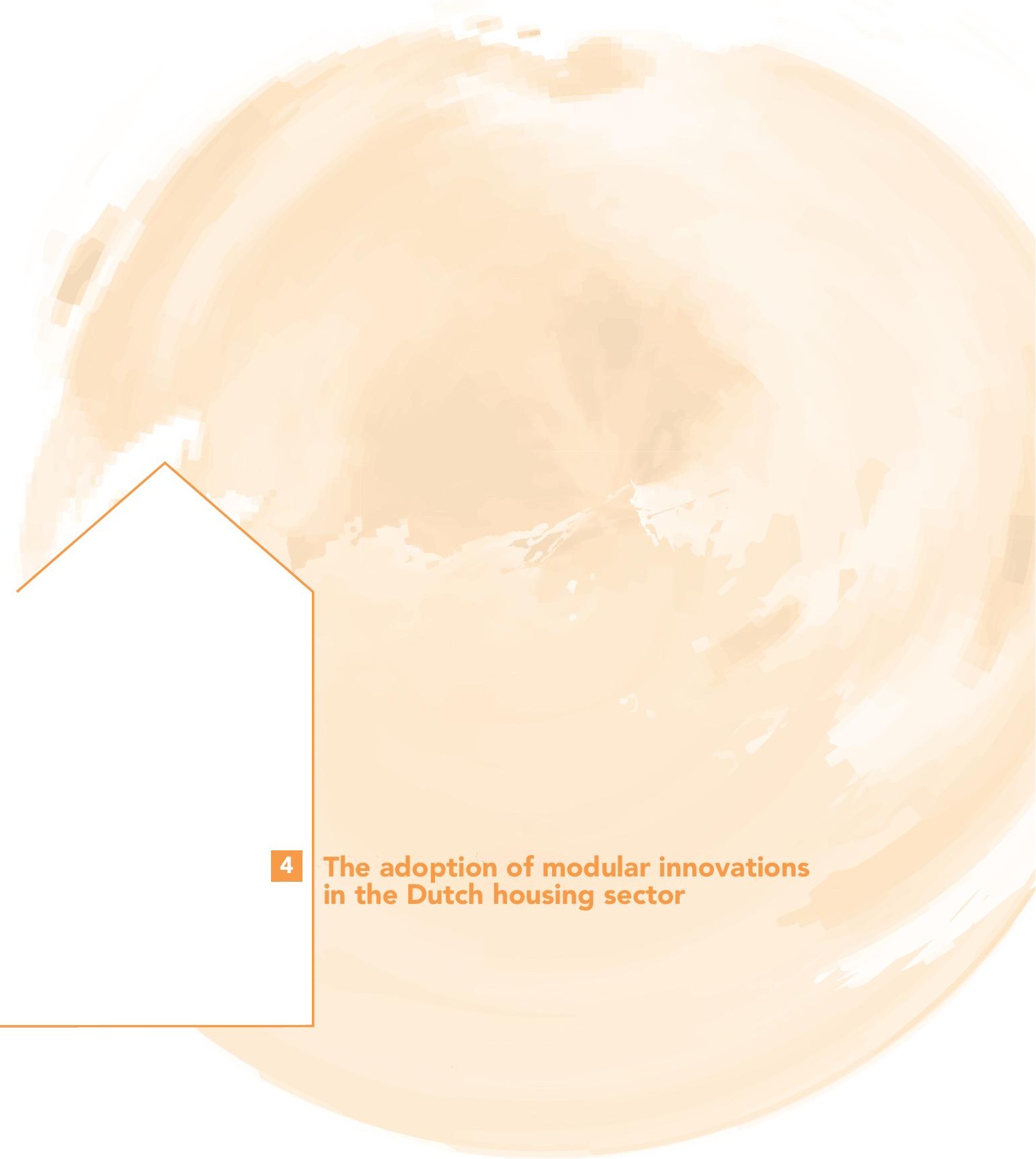




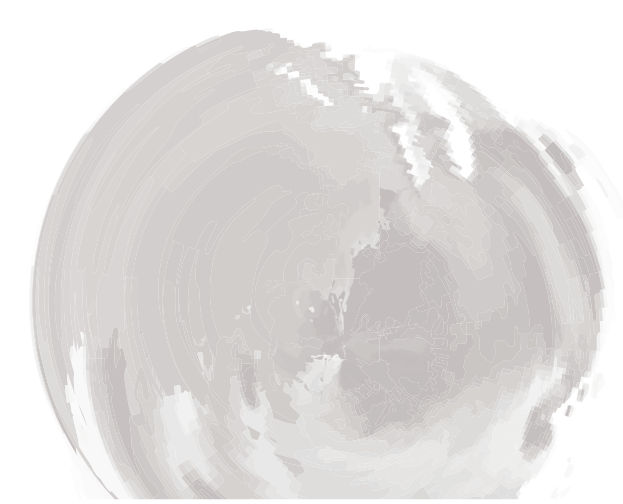

\section{The adoption of modular innovations in the Dutch housing sector} This chapter is under review at a scientific journal ${ }^{14}$

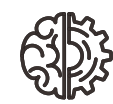

\section{Abstract}

This articles reports about a multiple case study about the adoption of modular innovations in the housing sector. The adoption of modular innovations in the housing sector is important not only because it enables mass-customization of housing designs and construction, but also because it allows adaptation, deconstruction and reuse. As such, it contributes to realizing a circular building stock. An extensive literature review and in-depth multiple case study have been conducted. For the multiple case study, three innovative modular housing solutions were selected - a modular renewable energy system, a modular bathroom pod and an integrated photovoltaic modular roof. The multiple case study helped to identify ten variables that influence adoption of these modular products. A closer analysis revealed that several of these variables were addressed in conjunction. Based on this analysis, four causal mechanisms that determine the potential adoption of modular innovations were deduced. This study is among the first in-depth empirical studies to link innovation adoption to modularity theory. It is also the first to investigate the internal causality of adoption variables in housing projects and this enables us to explain how and why modular housing products are adopted. Managerial implications and future research directions are also addressed. 


\subsection{Introduction}

Along with growing concerns regarding climate change (ECSO, 2017; Eurostat, 2019a), labour shortages and insufficient housing supply (ECSO, 2017; Eurostat, 2019b; Pittini et al., 2017), the relatively low levels of customization of housing design is one of the main themes in housing innovation (Barlow et al., 2003; Craig and Roy, 2004; Ozaki, 2003). It is believed that modularity, which has lately gained substantial attention, could significantly contribute to addressing these concerns. Modularity is seen as a key element in strategies involving platform-driven product development, supply chain integration, risk mitigation and sustainability (Jayaram and Vickery, 2018). Recently, modularity has also been promoted by the circular economy movement as it could contribute to a circular building stock driven by the need to reduce the growing environmental impact of resource-intensive construction practices (Ellen MacArthur Foundation, 2015a, b; van den Berg, 2019).

The reported advantages of modularity include increased product variety (Muffatto and Roveda, 2000; Patel and Jayaram, 2014; Sanderson and Uzumeri, 1995), reduced complexity (Meyer et al., 1997; Salvador, 2007), more rapid product development (Meyer et al., 1997), reduced product development costs and increased product reliability (Muffatto and Roveda, 2000). Modularity strategies balance the demand for individualised housing solutions with economies of scale linked to mass production (Naim and Barlow, 2003). Tu et al. (2004) define modularity as "the practice of using standardized modules so they can be easily reassembled/rearranged into different functional forms, or shared across different product lines". Modular products enable the product delivered, i.e. entire houses, to be formed of subsystems that can be designed independently and then reconfigured into new types of housing, allowing economies of scale and scope (Baldwin and Clark, 2000; Halman et al., 2008; Veenstra et al., 2006). As a result, modularity allows housebuilders to cope with a large variety of customer requirements and increasing technical and organizational complexity in housebuilding (Salvador, 2007).

Despite the potential advantages of modularity in housebuilding, the housing industry has still not widely adopted modularity. However, there are signs that this is changing. As demonstrated by Bertram et al. (2019), the housing industry is adopting digital technologies that enhance both variability and repeatability of designs, improve precision and productivity in manufacturing, and facilitate logistics. Countering the former reputation of prefabricated housing as an ugly, cheap and poor-quality option, builders are focusing on sustainability and aesthetics, and also targeting the higher end of the market. Thus, an important question is now what determines the eventual success or failure of newly developed modular products being adopted in the housebuilding sector? 
Currently, there is little empirical research available on the potential adoption of modular innovations in the housing sector. In order to bridge this gap in the literature, we addressed the following research questions:

1. What determining factors and causal mechanisms influence the adoption of modular innovations in the housing sector?

2. To what extent can the theory on modularity help to explain the adoption of modular innovation in the housing sector?

These research questions have been addressed by conducting a multiple case study investigating the adoption of three modular product innovations. These three case studies address a modular renewable energy system, a modular prefabricated bathroom pod and a modular based photovoltaics (BIPV) roof system. The results of this study are twofold. First, it has empirically revealed ten factors that affect the potential adoption of modular innovations in housing projects. Second, a cross-case analysis identified four mechanisms linking these ten factors to the adoption of modular innovations in housing projects. As such this study also contributes with four propositions that could guide future research as well as the development of modular innovations.

The remainder of this article is organised as follows. Section 2 reviews the literature on modular innovation and its adoption in general, and more specifically in the housing sector. Next, in Section 3, we explain the research methodology. Section 4 describes the findings from the three independent case studies, the cross-case analysis and the developed propositions. The article concludes with a discussion about the main contributions and limitations of this study and a number of suggestions for further research.

\subsection{Literature background}

In subsection 2.1, we first provide a general introduction to the concept of modularity. Next, we distinguish three dimensions of modularity as described by Fine et al. (2005), Elram et al. (2007) and Campagnolo and Camuffo (2010). This is followed by a review of the literature concerning modularity in housing in subsection 2.2. In subsection 2.3, a three-dimensional modularity typology for modular housing projects is derived based on the available literature. Subsection 2.4 provides an overview of the research findings on the adoption of innovation in housing projects and, in subsection 2.5, we discuss the specific adoption of modular innovations in housing projects.

\subsubsection{Modularity: a general introduction}

The construction and housebuilding industry has been characterised by Gann and Salter (2000) as a Complex Product Systems (CoPS) industry. For CoPS, modularity is considered as a key strategy to innovate and modernise (Bygballe and Ingemansson, 2014; Gann and 
Salter, 2000; Hobday, 1998, 2000). Following Salvador (2007), a complex product system is seen as modular to the extent that it has separable subsystems that can be combined in different ways to configure product variants. Modular product systems are characterised by a one-to-one mapping between functions and physical subsystems and have standardized, decoupled interfaces (Ulrich, 1995). Decoupling implies that changes in one subsystem do not require changes in other interfacing subsystems (Baldwin and Clark, 2000) as long as they can take place within the boundaries of the interface specifications set up front (Hofman et al., 2016). This allows firms to select modular innovations and use them in combination with other unchanged subsystems to configure a new overall system. Thus, within a modular product system, product subsystems (modules) are interchangeable, autonomous, individually upgradeable because the interfaces are standardised (Hofman et al., 2009; Ulrich, 1995). Modularity is a relative concept and therefore product modularity should be measured along a continuum, from integral to fully modular product systems (Campagnolo and Camuffo, 2010; Mikkola, 2006). Modularity has been successfully introduced in various industries (Baldwin and Clark, 1997; Sanchez and Mahoney, 1996; Ulrich and Eppinger, 2012) of which personal computers (Langlois and Robertson, 1992) power tools (Utterback, 1996), kitchens (Franke et al., 2008), ships (Choi and Erikstad, 2017) and cars (Wilhelm, 1997) are very good examples.

\subsubsection{Three dimensions of modularity}

Fine et al. (2005) emphasised the need to balance modularity in product, process and supply chain design in order to introduce a potentially successful modular product.

Product modularity - modular products are characterised by a clear mapping between functions and components. As such modules are relatively autonomous with loose coupling between modules that are connected with each other using standard interfaces.

Process modularity - modular products can be autonomously and independently produced across time and space. That is, components can be produced across multiple time intervals and at dispersed locations. Nevertheless, the selected production and manufacturing techniques set the economic territory (Dicken and Malmberg, 2001) which can be determined in particular by various logistic and site operations restrictions (Blismas and Wakefield, 2009; Hwang et al., 2018; Lu et al., 2018; Rahman, 2013). Next, when brought together, modules can be installed independently from each other and, over time, substitution and recombination is possible without the need to dismantle the whole system.

Supply chain modularity - Firms within a modular supply chain are loosely coupled to each other with a clear distribution of responsibilities reflecting a high level of standardisation and network stability. Loose coupling reflects a certain relative distance between the stakeholders in terms of geographic, organisational, cultural and electronic proximity. 


\subsubsection{Modularity in the housing sector}

Modularity is considered to benefit the construction industry and in particular housing. It has been the subject of study in various scientific articles (da Rocha et al., 2015; Doran and Giannakis, 2011; Halman et al., 2008; Hofer and Halman, 2005; Hofman et al., 2009; Lennartsson and Björnfot, 2010; Pero et al., 2015; Viana et al., 2017) and doctoral dissertations (Hofman, 2010; Jensen, 2014; Sheffer, 2011; Wolters, 2002). Previous research has particularly focused on how modularity in housing can be conceptualised and operationalised, what the benefits could be and how to organise and manage modularity in the context of housing. The key reported benefits of modularity in housing encompass the potential to reduce process complexity, increase flexibility in product design, increase the efficiency of product development and manufacturing and improve organisational agility to address changing market conditions and improve competitiveness through product differentiation (Halman et al., 2003; Halman et al., 2008).

The three dimensioned modularity concept developed by Fine et al. (2005) has been shown to be a valuable model to describe and analyse product, process and supply chain modularity in the housing sector (Voordijk et al., 2006; Wolters, 2002). It has also demonstrated its added value as a guide to modular innovation in construction (Lennartsson and Björnfot, 2010).

\section{Product modularity in the housing sector}

Four types of product modularity have been identified within housebuilding (Hofman et al., 2009; Jensen, 2014; Thillart, 2004; Voordijk et al., 2006; Wolters, 2002). The first type is the variant type: housing clients can select between predefined basic housing variants. The second type is the core type in which clients can select a number of modules and connect them to a fixed core. The third type, sectional design, can be related to the previous type but lacks a single core to which all modules connect, thereby substantially increasing design freedom. For example, attaching a prefabricated 3-D garage via a standard interface would be a sectional extension, but also piping systems typically adhere to a sectional architecture (Ulrich, 1995). The final type is a bus architecture in which modules connect to a common core via the same type of interface, for example adjustable roof racks for automobiles typically use a universal bus that can be combined with a diversity of accessories that match specific car types (Ulrich, 1995). 
Process modularity in the housing sector

Five core production and manufacturing techniques have been identified that facilitate process modularity in housebuilding (Gibb, 1999; Grimscheid and Scheublin, 2010; Hartley and Blagden, 2007; NAO, 2005; NHBC, 2016; Taylor, 2010):

1. Volumetric pre-assembly: three dimensional structural modules produced in a

2. factory, fully fitted out before being transported to site and installed onto prepared foundations to form dwellings.

3. Pod pre-assembly: three dimensional modules which enclose usable space and are typically factory finished internally. In contrast to volumetric pre-assemblies, pods do not form the buildings structure itself and are therefore applied in conjunction with other construction methods, e.g. toilet and bathroom pods.

4. Panelised pre-assembly: two dimensional (non-)structural elements built in a factory and transported to site for assembly into a three-dimensional structure.

5. Component manufacturing and pre-assembly: sub-assemblies and components, mostly characterised by a simple one-to-one mapping between function and physical appearance, which need to incorporated or integrated within the dwelling on-site.

6. Site-based manufacturing: innovative methods of on-site construction methods, including the use of conventional components in an innovative way.

Supply chain modularity in the housing sector

The construction industry produces complex product systems (Gann and Salter, 2000) and it has been classified as an archetypal network industry (Bygballe et al., 2015; Miozzo and Dewick, 2004). Within this context, three modular housebuilding supply chain setups have so far been identified: a closed system; a hybrid system; and an open system (Segerstedt and Olofsson, 2010; Tennant and Fernie, 2014). Various scholars have linked modular products to a modular, hybrid supply chain configuration (Barlow et al., 2003; Doran, 2003; Doran and Giannakis, 2011; Fine, 2000; Fine et al., 2005; Pero et al., 2015; Salvador et al., 2002; Salvador et al., 2004). In short, within a closed system, all players are directly engaged throughout the project life cycle and contracted and coordinated by the housebuilder. The modular system involves a fixed network of suppliers (or co-makers). Finally, the open system consists of loosely coupled, autonomous and dispersed suppliers. See Table 4.1 for a detailed account of the characteristics of the different supply chain configurations. 
Table 4.1: Characteristics of three types of supply chain set-ups found in housing (adapted from Tennant and Fernie (2014))

\begin{tabular}{|c|c|c|c|}
\hline Supply chain set-up & Open & Hybrid/modular & Closed \\
\hline Mode of governance & $\begin{array}{l}\text { Market, focus on supply } \\
\text { chain and interface be- } \\
\text { tween supply and con- } \\
\text { struction site activities }\end{array}$ & $\begin{array}{l}\text { Network, focus on trans- } \\
\text { ferring activities from the } \\
\text { construction site to the } \\
\text { supply chain }\end{array}$ & $\begin{array}{l}\text { Hierarchy, focus on inte- } \\
\text { gration of construction } \\
\text { site and supply activities }\end{array}$ \\
\hline $\begin{array}{l}\text { Economic relationship } \\
\text { and procurement }\end{array}$ & $\begin{array}{l}\text { Price based, traditional } \\
\text { lump-sum }\end{array}$ & $\begin{array}{l}\text { Trust based, partnering } \\
\text { approach }\end{array}$ & $\begin{array}{l}\text { Authority based, in- } \\
\text { house approach }\end{array}$ \\
\hline $\begin{array}{l}\text { Social structure and } \\
\text { working culture (cultural } \\
\text { proximity) }\end{array}$ & $\begin{array}{l}\text { Temporal coalition, ad- } \\
\text { versarial working culture }\end{array}$ & $\begin{array}{l}\text { Community based, } \\
\text { partnering based on } \\
\text { long-term sustainable } \\
\text { relationships }\end{array}$ & Institutional, authority \\
\hline Geographical proximity & Across regions & Regional & Local \\
\hline $\begin{array}{l}\text { Object availability and } \\
\text { number of competitive } \\
\text { suppliers }\end{array}$ & High & Moderate & Low \\
\hline $\begin{array}{l}\text { Customer order specifica- } \\
\text { tion decoupling point }\end{array}$ & $\begin{array}{l}\text { Standard products, select } \\
\text { variant among competi- } \\
\text { tive alternatives }\end{array}$ & $\begin{array}{l}\text { Configure or modify to } \\
\text { order based on standards } \\
\text { modules and generic } \\
\text { product structures }\end{array}$ & $\begin{array}{l}\text { Engineer to order based } \\
\text { on norms and standards }\end{array}$ \\
\hline Technology & $\begin{array}{l}\text { Craftsmanship in one-off } \\
\text { projects }\end{array}$ & $\begin{array}{l}\text { Standardization and rep- } \\
\text { etition across projects }\end{array}$ & $\begin{array}{l}\text { Production line, continu- } \\
\text { ous stream of industrial } \\
\text { produced products define } \\
\text { projects }\end{array}$ \\
\hline Availability & $\begin{array}{l}\text { Off the shelf, standard } \\
\text { materials and products, } \\
\text { strong competition }\end{array}$ & $\begin{array}{l}\text { Standard products and } \\
\text { modules, moderate } \\
\text { competition }\end{array}$ & $\begin{array}{l}\text { Customized solutions, } \\
\text { low competition }\end{array}$ \\
\hline $\begin{array}{l}\text { ICT applications to man- } \\
\text { age supply chain (elec- } \\
\text { tronic proximity) }\end{array}$ & High & Moderate & Low \\
\hline
\end{tabular}

Table 4.2 provides an overview of the types of product, process and supply chain modularity distinguished above. Several indicators have been developed to characterise the level of product, process and supply chain modularity, ranging from low (integral) to high (modular). Table 4.2 also provides an overview of these indicators as proposed in the literature to characterise the levels of product, process and supply chain modularity in housing projects. 
Table 4.2: Modularity types and suggested indicators to characterise the modularity level in the housing sector

\begin{tabular}{|c|c|c|}
\hline Modularity concept & Typology & Indicators \\
\hline Product modularity & $\begin{array}{l}\text { Types of product modularity } \\
\text { (Mahoney, 1995; Sanches and Mahoney, } \\
\text { 1996; Wolters, 2002; Van den Thillart, 2002; } \\
\text { Jensen, 2014): } \\
\text { 1. Variant } \\
\text { 2. Core } \\
\text { 3. Sectional } \\
\text { 4. Bus }\end{array}$ & $\begin{array}{l}\text { Product modularity indicators } \\
\text { (da Rocha and Kemmer, 2018; Gosling et } \\
\text { al., 2016; Hofman, 2010; Pero et al., 2015; } \\
\text { Voordijk et al., 2006; Wolters, 2002): } \\
\text { - Distinctiveness of modules } \\
\text { - Loose coupling between modules; } \\
\text { tight coupling within modules } \\
\text { - Clearmapping between functions and } \\
\text { components } \\
\text { - Standardisation of interfaces }\end{array}$ \\
\hline Process modularity & $\begin{array}{l}\text { Types of process modularity } \\
\text { (Gibb, 1999; NAO, 2005; NHBC, 2006; Hart- } \\
\text { ley and Blagden, 2007; Taylor, 2010): } \\
\text { 1. Volumetric pre-assembly } \\
\text { 2. Pod pre-assembly } \\
\text { 3. Panelised pre-assembly } \\
\text { 4. Component manufacture \& sub-as- } \\
\text { 5embly } \\
\text { 5. Site-based manufacturing }\end{array}$ & $\begin{array}{l}\text { Process modularity indicators } \\
\text { (da Rocha and Kemmer, 2018; Gosling et } \\
\text { al., 2016; Hofman, 2010; Pero et al., 2015; } \\
\text { Voordijk et al., 2006; Wolters, 2002): } \\
\text { - Autonomous, independent production } \\
\text { (in time and space) } \\
\text { - Territorial economy (restricted to 'terri- } \\
\quad \text { tory' due to transportation limitations; } \\
\text { location of co-makers / key component } \\
\text { suppliers, etc.) } \\
\text { - Substitution and recombination } \\
\text { (coupling \& interdependency) } \\
\text { - Installation task interdependency }\end{array}$ \\
\hline $\begin{array}{l}\text { Supply chain } \\
\text { modularity }\end{array}$ & $\begin{array}{l}\text { Types of supply chain modularity: } \\
\text { 1. Closed system: all players directly } \\
\text { engaged across project life cycle, coor- } \\
\text { dinated (by housebuilder) } \\
\text { 2. Modular system: interlocked, fixed } \\
\text { principal suppliers } \\
\text { 3. Open system: loosely coupled and } \\
\text { dispersed (autonomous) }\end{array}$ & $\begin{array}{l}\text { Supply chain modularity indicators } \\
\text { (da Rocha and Kemmer, 2018; Gosling et } \\
\text { al., 2016; Hofman, 2010; Pero et al., 2015; } \\
\text { Voordijk et al., 2006; Wolters, 2002): } \\
\text { - Economic relationship- subcontracting } \\
\text { vs partnering; distribution of respon- } \\
\text { sibilities } \\
\text { - Customer specification decoupling } \\
\text { point } \\
\text { - Cultural proximity (embodied by soci- } \\
\text { al structure and working culture) } \\
\text { - High-electronic proximity } \\
\text { - } \text { Geographical proximity } \\
\text { Purchased object and availability } \\
\text { (number of competitive suppliers) }\end{array}$ \\
\hline
\end{tabular}

\subsubsection{The adoption of innovations in housing projects}

Studies into the factors that affect the adoption and diffusion of technology innovation in the housing sector have received increasing attention in the past few decades. In a recent extensive literature review, 94 scientific articles were identified which addressed the adoption of various types of technology innovation in the housing sector (Van Oorschot et al., 2020). This review indicates that scholars have primarily focused on two areas of technological innovations in the housing sector. The first concerns the potential adoption of technological innovations in the field of sustainable housing. The second area addresses the adoption of technological innovations in the field of industrial housebuilding.

Both domains of technological innovations can be linked to the current debate and the search for solutions that decrease the high environmental impact of construction, and improve the poor quality and low efficiency seen in housebuilding. 
Furthermore, the conceptual innovation adoption framework developed as part of the above review includes four categories of innovation adoption determinants and their underlying variables. The four categories (with a total of 21 underlying variables) are: the influence of the environment; the product's characteristics and innovation attributes; industry characteristics; and adopter characteristics. The first group of environment-linked variables covers macroeconomic variables including regulatory, governmental steering mechanisms, external social support and financing opportunities. The second product-related group contains attributes that are in part similar to the innovation attributes identified by Rogers (2003): relative advantage; complexity; compatibility; result demonstrability and trialability and the attributes of auxiliary resources (like for example assessment tools and standards and certification); economic feasibility; and perceived risk. Industry-related characteristics were identified as a third group of variables that affect the adoption of technological innovations in housing projects. Also, industry fragmentation, the application of traditional procurement strategies, frequent periods of economic downturn and an industry primarily composed of SMEs were identified as creating inertia to the adoption of technological innovation in housing. In contrast, the involvement of clients and highly motivated stakeholders, as well as change agents, can positively affect adoption. Finally, various adopter characteristics were found to affect adoption. On the individual level, awareness of the innovation, information availability and 'disconnected behaviour', reflecting the inconsistency between homeowners preferences and actual behaviour, were identified as important adoption variables. Likewise, on the organisation level, available skills and knowledge, as well as motivation and an innovation culture, were considered to affect the adoption of innovations in the housing sector.

Although existing studies on the adoption of innovation in the housing sector have revealed various adoption variables, some issues remain. First, several of the identified variables lack a sound theoretical underpinning. Second, several studies fail to make sufficiently clear what type of innovation is being adopted and by whom (a particular individual, a project team or an organisation).

Another gap in the literature concerns the lack of empirical data on the mechanisms and underlying variables that affect the adoption of specific types of innovation, such as the adoption of modular products. Another observation concerns the data collection approach in that, in many of the survey studies, the respondents were not necessarily involved in the adoption decision-making process. This inevitably limits understanding of innovation adoption in housing.

\subsubsection{The adoption of modular innovations in housing projects}

Studies addressing the adoption of modular products in the construction industry are very few in number (Azhar et al., 2013; Sheffer, 2011). Sheffer (2011) demonstrated in her doctoral thesis on implementing energy-efficient innovations in US buildings that, compared to integral innovations, modular innovations are much more likely to be adopted. 
This supports the claim that modularity could be viewed as a potentially valuable strategy to sustain innovation and change in the sector. Azhar et al. (2013) identified 12 critical decision-making factors and 6 key constraints to selecting modular construction over the conventional 'stick-built' technique for commercial building projects. In their study, Azhar et al. (2013) identified "supply chain integration and effective collaboration among project stakeholders already in the early stages of the project" as a key factor in the adoption of modular construction. The importance of supply chain integration and the degree of coupling between the involved stakeholders have also been emphasised by Doran and Giannakis (2011) and Hofman (2010) who explored the application of modular practices in construction. To compete effectively with traditional onsite solutions, Doran and Giannakis (2011) observed an increase in supply chain integration for modular solutions. In addition, Hofman (2010) found that a higher degree of organizational coupling among innovation network members, together with the availability of product design rules, significantly improved the commercial success of modular product innovations. Further, several barriers have been identified that hinder the diffusion of modular construction: poor building design in terms of suitability for modularization; a lack of awareness of the benefits; non-availability of prefabrication units in the project vicinity; restricted site layout; and design rigidity (Azhar et al., 2013). However, studies into the adoption and diffusion of modular products specifically in housing projects are, to the best of our knowledge, unfortunately lacking.

\subsection{Research methodology}

A multiple case study, involving three different cases, was conducted to gain insight into factors that influence the adoption of modular products in the housing sector (Becker, 2017). This methodology was chosen because case studies allow one to retain holistic and meaningful characteristics of real-life events, situations and general settings. Moreover, case studies are particularly meaningful when studying a contemporary phenomenon within its real-life context (Yin, 2013).

The selection of the case studies was governed by three specific criteria. First, products had to improve the efficiency of the construction process of dwellings. Second, products had to be modular (i.e. self-contained, easily (de-)coupled, with standard interfaces, relatively standard products and replaceable without affecting other components of the house). Third, products had to be new, already available on the market and being adopted in housing projects.

The first criterion ensured the product was situated in the context of this study. The second criterion ensured that the product was modular, and the third criterion ensured that the products were innovative, available and being adopted in housing projects.

Having set these criteria, we were able to select three modular products as the basis for the case studies. 
The products selected are all modular innovations that are being introduced onto the Dutch market for newly constructed and/or renovated dwellings. The unit of analysis is the innovative modular product developed by suppliers and implemented in housing projects.

\subsubsection{Data collection}

Table 4.3 provides an overview of the sources that were used to obtain data for the case studies. For each case study, 3 to 4 interviews were conducted with key stakeholders, such as the companies supplying the components of the modular products, the contracting companies and installation companies. In total, 10 interviews, varying in length from 50 to 90 minutes, were conducted with 10 different companies. The average duration of the interviews was 60 minutes. The stakeholders who were interviewed held important managerial positions, possessed deep knowledge about the organisation and were involved in the decision-making process of adoption.

An interview protocol was created for the interviews. Semi-structured interviews were used to enable follow-up questions and uncover aspects that were considered as relevant during each interview. All the interviews were recorded and transcribed. The transcripts were sent back to the respondents to verify the content. None of the transcriptions had to be modified. The interviewees also provided documents that enabled us to refine the description of the characteristics of the three modular products being studied and the description of the adoption mechanisms. The stakeholders answered questions explaining the nature of the modular product and its notable features, describing the process of adoption and explaining the key determinants of adoption. Validation workshops were later held.

Table 4.3: Overview of data sources per case

\begin{tabular}{|c|c|c|}
\hline & Sources of evidence & Details \\
\hline \multirow{3}{*}{$\begin{array}{l}\text { Case 1: } \\
\text { Modular } \\
\text { renewable } \\
\text { energy } \\
\text { system }\end{array}$} & Interviews & $\begin{array}{l}\text { Three interviews with the supplier (innovation manager renewables), a } \\
\text { contractor (technical director) and an installer (innovation manager)*. }\end{array}$ \\
\hline & Documents & Product brochures. \\
\hline & Workshop session & $\begin{array}{l}\text { One workshop session with interviewees, another installer and experts in } \\
\text { the field. }\end{array}$ \\
\hline \multirow{3}{*}{$\begin{array}{l}\text { Case 2: } \\
\text { Modular } \\
\text { Bathroom } \\
\text { Pod }\end{array}$} & Interviews & $\begin{array}{l}\text { Three interviews with the supplier (projects and concepts manager), } \\
\text { contractor (innovation manager) and installer (project leader). }\end{array}$ \\
\hline & Documents & Product brochures. \\
\hline & Workshop session & One workshop session with interviewees and experts in the field. \\
\hline \multirow{3}{*}{$\begin{array}{l}\text { Case 3: } \\
\text { Modular } \\
\text { BIPV Roof }\end{array}$} & Interviews & $\begin{array}{l}\text { Four interviews with the supplier (managing director), contractor (director), } \\
\text { architecture firm (architect)* and energy provider (business developer). }\end{array}$ \\
\hline & Documents & Product and project brochures. \\
\hline & Workshop session & $\begin{array}{l}\text { One workshop session with interviewees, additional representatives of the } \\
\text { organisations and experts in the field. }\end{array}$ \\
\hline
\end{tabular}




\subsubsection{Data analysis}

Data analysis consists of examining, categorising, tabulating, testing or otherwise recombining evidence to draw empirically based conclusions (Yin, 2013). In the first step of the data analysis process, we coded the transcripts of the interviews. Coding consists of segmenting, separating and disassembling the data obtained during data collection into smaller units of information that are easier to handle, and later the data are reassembled and analysed. The data analysis was conducted using the qualitative data analysis method proposed by Boeije (2009). After analysing the codes for each case study, preliminary conclusions were drawn and a summary of the major findings compiled.

\subsubsection{Validating workshops}

To validate the data collected in the individual interviews and the results of our data analysis, workshop sessions were organised and conducted for each of the three case studies. The workshops are best described as moderated discussion sessions where the most important findings from the interviews and the data analysis were discussed with the members of each case study. The sessions focused on discussing the major findings obtained from the individual interviews. These sessions allowed the participants to clarify their views and opinions and to discuss them with all the participants of the case study. The three workshop sessions each had a duration of approximately 90 minutes. All the interviewees were invited to their respective workshop, and the participation rate of the workshops was $80 \%$. In one of the workshop sessions, additional experts from the companies participated to add value to the discussion. The sessions were recorded and listened to later with the major findings from the workshops being then transcribed.

\subsubsection{Cross-case analysis}

Once the data were available in organised segments, a cross-case analysis took place following the recommendations of Miles and Huberman (1994) and Miles et al. (2014). The cross-case analysis involved a variable-oriented approach where variables were compared across the three case studies. The case-specific determinants were compared with each other to arrive at generic conclusions with respect to the adoption variables. These adoption variables were derived following several iterations of re-examining the case data and repeating the cross-case analysis (see Table 4.5). The eventual cross-case analysis was followed by an analysis of possible interrelationships between the identified adoption variables. Based on this analysis, it was possible to deduce four causal mechanisms that determined the adoption of the modular components in the three case studies. As a result, four propositions were formulated that could guide future research on the adoption of modular innovations in housing projects. 


\subsubsection{The adoption of modular innovations in housing: three case studies}

In this section we address the modularity of the three case studies along three dimensions: product modularity, process modularity and supply chain modularity, in accordance with Table 4.1. See also Table 4.4 for an overview of the three cases.

\section{Case 1: Modular renewable energy system}

Product modularity - Besides a highly insulated building envelope various renewable energy technologies are required to construct an energy efficient dwelling. These technologies include solar photovoltaic systems, heat pumps and ventilation units with heat recovery to provide heating, ventilation and hot water. Conventionally, these technologies are installed separately from each other in a dwelling which is rather inefficient: it is complex to make all subsystems to work as a singly "engine", the technical installation takes up a lot of space and installation on-site is labour intensive. The modular renewable energy system (RES) was developed to cope with these inefficiencies. The RES consists of modular renewable energy components which can be mixed and matched. Thus, product modularity is considered high in terms of distinctiveness, loose coupling between modules, clear mapping between function and components and standardization of interfaces. The RES can be installed in both newly built and major renovation projects.

Process modularity - The RES consists of many components which are pre-assembled at a central production location and transported to the construction site following the planning provided by the (sub-)contractor. The key components, a heat pump, a ventilation unit and monitoring equipment, are developed and produced in-house by the supplier of the RES and complemented by various components from second-tier suppliers. A specialised installer, not the supplier of the modules, is responsible for on-site installation and commissioning of the indoor climate equipment. This includes connecting the modules to piping and ducts that are already integrated in the dwelling within other subsystems (walls and floors). After the system is commissioned, the original equipment manufacturer of the RES is responsible for performance monitoring and maintaining the installed renewable energy technologies.

Supply chain modularity - In 2014, the contractor and the supplier of the renewable energy technologies came into contact with each other through a national networking forum on energy efficient retrofitting. Both parties saw the necessity of working in partnership to develop a conceptual solution for energy efficient renovation projects. The overall performance of the renovated buildings depends not only on the renewable energy technologies constituting the RES, but also on the integrated performance of various modules and subsystems, including building envelope modules and other renewable energy technolo- 
gies. As such, the supply chain involved in carrying out the renovations can be characterised as a modular set up based on long-term collaboration, i.e. a modular supply chain that reflects a clear distribution of responsibilities between fixed principal suppliers to ensure the overall performance delivered to the client. In particular in order to overcome the complexity of integrating the technology in the dwelling, long-term partnerships are key to getting the technology adopted across housing projects. The RES is currently diffusing into the Dutch housing market in both new-build and energy-efficient renovation projects.

\section{Case 2: Modular Bathroom Pod}

Product modularity - Overcoming various problems linked to the traditional, labour-intensive construction of bathrooms, modular bathroom pods are produced off-site and in a factory-based approach. With a rigorous quality assurance process, the highest product quality standards are achieved. In addition, the bathroom is customisable in terms of layout and finishing: it can be tailored to satisfy the different requirements that projects might have. The bare structure of the bathroom consists of standardised and certified compound walls made of bio-based materials (flax, wood and plaster). The walls include internal cavities to install water pipes and electrical wiring. A special vinyl is used to cover the walls and floor which has the appearance of bathroom tiles. When installed on the site, the appearance is as a traditional bathroom. In terms of modularity, the bathroom pod can be characterized as a distinctive module with a clearly defined functionality. Furthermore, the interfaces are standardized with loose couplings between the module and the dwelling whereas tight couplings are found within the pod.

Process modularity - A group of innovative firms in the housing sector established the "Innovative Concept Building" (ICB) supply chain to develop a housebuilding system based on a so-called one-piece-flow approach and a continuous production streaming process. This resulted in a 'vertical' production line (i.e. constructing one house at a time) that could build the shell of a dwelling in a single day and then finish the dwelling within one week without increasing costs. To reduce construction time and costs, the contracting company set the goal of building the dwelling with no more than 32 crane charges per house in contrast to an average of 64 loads. Speeding up the construction process could only be achieved by using modular components, such as the bathroom pod. A third partner from the ICB supply chain, an installer, is responsible for the onsite installation work.

Supply chain modularity - In 2009, the Innovative Concept Building (ICB) supply chain was initiated as an association of close-collaborating suppliers and contractors with long-lasting relationships. They aim to improve the quality, efficiency and innovativeness of the construction process while reducing construction costs. In 2013, the contractor involved came up with a proposition to fundamentally change the traditional work practices by going beyond single project organisational relationships and by utilising single elements, one-piece-flow and continuous production streaming processes. 
This resulted in the development of a modular construction process and, subsequently, a modular supply chain was instigated. This context spurred innovations like the development of the bathroom pod. Although close network ties exist within the ICB supply chain, the bathroom pod developer does not want them to be produced exclusively for a single party and therefore the pods are intended to be supplied beyond the ICB network. So far, the bathroom pods have not been produced and installed in large quantities, and both the product and supply chain seem to be treading water.

\section{Case 3: Modular BIPV Roof}

Product modularity - The modular, building integrated photovoltaics (BIPV) roof, or simple energy roof, was developed as a modular roofing solution offering integrated functions. These functions relate to providing insulation, daylight and energy, that can be linked to specific components: roof boarding, a dormer window and photovoltaic panels. One of the key drivers for developing the integrated BIPV roof was the poorly valued aesthetics of PV panels installed on top of tiled roofs. In comparison, in the BIPV roof, the photovoltaic panels are integrated in the roof, giving it the appearance of a traditional tiled roof. This product can be used in new construction projects as well as in energy-efficiency renovation projects. Moreover, the three core components can be installed separately from each other and therefore considered modular at both the building as the product level, i.e. standardized interfaces based on loose couplings are developed to connect the modular $\mathrm{BIPV}$ roof to the building and to connect the three core distinctive technologies.

Process modularity - Although part of an integrated design, the three core components are separately produced by three established suppliers and combined and installed onsite. The BIPV roof is installed and commissioned by a specialised subcontractor following the design of the modular BIPV roof's system integrator following a one-stop-shop strategy. The one-stop-shop concept also encompasses monitoring the performance of the BIPV roof and taking care of the maintenance of the overall system. These services are provided by the supplier of the BIPV roof as part of the one-stop-shop concept.

Supply chain modularity - The demand for sustainable technologies is in particular stimulated by tighter energy efficiency regulations. The BIPV roof was developed as a one-stopshop modular product by a supplier of photovoltaic systems in collaboration with the R\&D departments of several international suppliers of building and roofing components. The modular BIPV roof consists of several standard building components for which standardised interfaces were developed. The system is installed by a nationally operating, specialised installer under the supervision of the photovoltaic systems supplier in its role as system integrator. The supply chain can be characterised as an open and dispersed system with loose couplings between the key suppliers involved, i.e. the primary components of the BIPV roof are off-the-shelf products which are connected using standardised interfaces. Today, the BIPV roof system integrator is attempting to get the product adopted on a large scale to move beyond demonstration projects. 

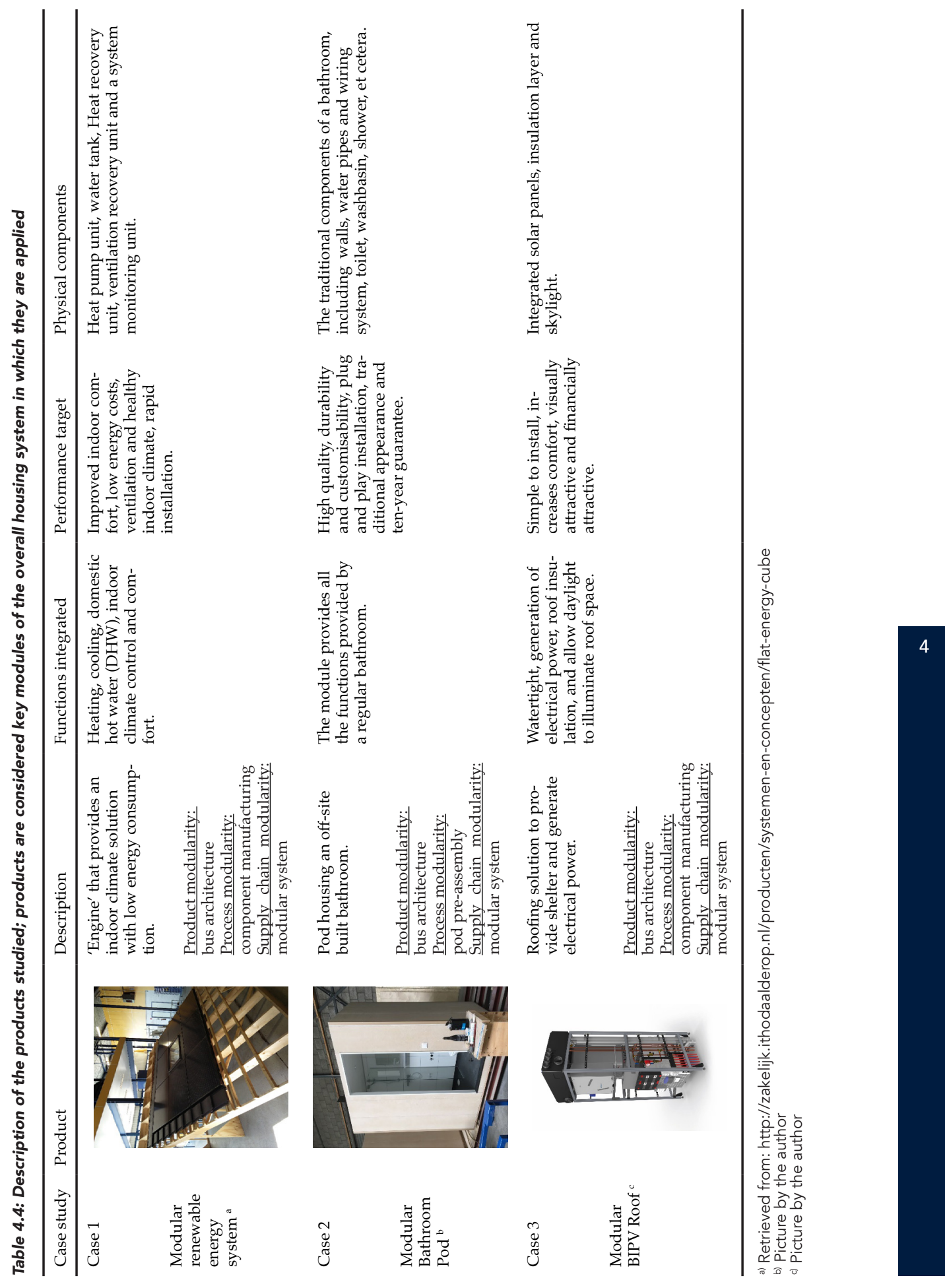


\subsubsection{The adoption of modular products in housing projects}

The three case studies revealed 10 factors that are key to adoption as shown in Table 4.5. Below, these adoption factors are discussed in more detail linked to the case studies in which they were addressed.

1. Relative advantage: Relative advantage is considered an important aspect in enhancing the adoption of modular products and in particular advantages linked to improved quality and production efficiency (cases 1 and 2) and energy efficiency (cases 1 and 3). Also, if the product is a highly visible element in the building envelope, making it stand out and be architecturally appealing will enhance its adoption. End-users will feel encouraged to adopt a product if it improves the architectural appearance of their dwelling (case 3). However, three issues reduce the positive effect of a relative advantage on adoption. First, a problem with the modular products is the difficulty clients experience in perceiving its relative advantage. Particularly in case studies 1 and 3, adoption was hindered by a lack of trialability. Both products improve home comfort and are intended to lower energy consumption, but this is difficult to perceive by clients who have never used the product before. Second, comfort and energy efficiency are often considered secondary issues in contrast to immediate benefits. Third, lower operational (i.e. energy) costs can only be perceived after the product has been operational for some time. In particular the adoption and implementation of sustainable technologies is characterized by a time-lag before a client experiences its intended benefits.

2. Investment and lowest cost orientation: In cases 1 and 3 , a change in the cost structure of the product across its operational lifecycle forms a barrier to the adoption of both these innovations. The products studied have higher initial costs but lower operational costs than tradition products which have lower initial costs and higher operational costs. The longer-term benefits are not perceived by clients, and this keeps them from adopting the product because it is perceived as initially too expensive. Similarly, if the criteria used by contractors in selecting suppliers are based on lowest initial costs, then the innovations will not be adopted.

3. Supply chain integration: In all three cases, it was clearly stated that the creation of stable and long-lasting partnerships (i.e. supply chain integration) between the stakeholders involved is crucial in achieving adoption. The respondents interviewed expressed their need to have trustful and transparent relationships between the partners involved in order to establish the necessary agreements that will lead to adoption. Participants agreed that stable relationships should not be bounded by the phases of adoption and implementation of the product (within and across projects) but rather that they should be extended through the operational lifecycle of the modular product. It was also noted that the larger the number of organisations and trades involved, the more complex partnering becomes. Nevertheless, all three cases had managed to develop close network ties among the involved partners. 
4. Boundary spanning and task interdependency: The modular products studied in this research each have more than one function coupled to the product. On the one hand, this brings the advantage of providing solutions to multiple problems in a single product. On the other hand, it has the disadvantage that, by integrating functions in one product, the supply chain of the product is reshaped, and this is not always positively viewed. Function integration should diminish complexity in the construction process by reducing the number of stakeholders the contractor should need to collaborate with in a project. The successful adoption of a product in the housing sector will only occur if the adoption of a product developed by a supplier is attractive to both the contractor and the end-user. The integration of functions found in all the three modular products studied in this research enhanced their adoption potential because they satisfy requirements from both contractors and end-users.

5. Design rules and standards: A key principle of modularity is the existence of an architecture and a set of standard design rules that function as a stable base on which to manage interfaces in the development and implementation of modular products. Establishing agreements about the interfaces between modules and the installation of the module in a dwelling requires intense collaboration between supplier and contractor. Although, from a technical perspective, interfaces are not difficult to establish; from a managerial perspective they are a time-consuming activity. For this reason, developing stable relationships enhances a product's potential adoption. All three case studies supported the view that adoption is hindered by the absence of design rules and standards and the complexity of boundary spanning activities to resolve technology misalignments.

6. Adequate skills and knowledge: Implementing innovative modular products in housing projects requires adequate skills and knowledge. This includes basic knowledge about the overall system and in-depth knowledge about the module itself. Further, knowledge and skills related to the full life cycle of the modular product are required, ranging from modular design and engineering to pre-production, installation, maintenance and removal. In the current, early stage of market introduction, the installation of the modular products was particularly emphasised by the respondents as crucial in terms of required knowledge and skills. As found in all three cases, modular innovations are typically not installed by the suppliers but are subcontracted to specialised installers. These installers need to be multiskilled to successfully install the products in a dwelling. In addition, the composition of the team that conducts the installation should not vary since repeating the process several times with the same team enables improvements to the installation process.

7. Regulatory: Current regulations require contractors to adopt and implement innovative products in order to improve the energy performance of housing. However, they do not encourage contractors to implement solutions that surpass the basic requirements mandated in the Building Code. Contractors tend to view the basic requirements of the Building Code as the maximum performance levels they should achieve. 
The modular energy efficient technologies studied in cases 1 and 3 outperform mainstream energy technologies and are not required to meet the basic energy efficiency requirements of the Building Code in the Netherlands. In addition, end-users have not been motivated to adopt energy efficient technologies. End-users are not aware of the potential savings that can be achieved through improvements in the energy performance of their dwellings. If contractors are being required to develop new energy efficient technologies then endusers should also be encouraged to improve the energy performance of their dwellings. Otherwise there will be an imbalance in the supply of and demand for energy efficient (modular) products, which hinders adoption as was found in case studies 1 and 3.

8. Supplier characteristics - product branding: The implementation of a modular product strategy represents a change to the traditional industry and market culture. Modular products are developed to be adopted across projects, resulting in a shift from a project-oriented to a product-oriented construction sector. Here, companies with a known brand are perceived as more reliable parties to collaborate with. Further, when companies have a known brand, the uncertainties and risks associated with adoption appear lower, and the product is implicitly of good quality. The importance of product branding was found in all three case studies.

9. Market maturity: Within traditional housing projects, clients are used to translating their demands into product specifications rather than specifying a specific performance level that needs to be met. Presenting performance specifications, as in cases 1 and 2, was seen as a barrier to the adoption of modular products. In case study 1 , the product is installed to provide a specified energy performance (zero energy bill) in the dwelling across its life cycle. In case study 2, the product has been developed to provide an enhanced performance level in the construction process of the dwelling: installing a bathroom in one day. The immaturity of the market conducting housing projects based on performance specifications, rather than specifying all the components, hinders a product's adoption. Most contractors do not have sufficient experience to work with these practices, and the market in general is also not used to this.

10. Innovation maturity - guarantees and liabilities: Providing a guarantee to cover the life cycle of a product reduces the uncertainties that are linked to the adoption of a modular innovation. From the perspective of the client, guarantees and liabilities ensure that certain safety and performance standards are met and indicate who can be hold responsible in the event of any deficiencies. Two other aspects inherently linked to product guarantees and liabilities also affect adoption. First, the perception of uncertainties diminishes as the number of completed projects increases. To some extent, this serves as a 'proof of concept' of the innovative modular product. Second, the maturity of an innovative modular product is also reflected by the ability of contractors and/or suppliers to convey the benefits of the product to other involved stakeholders. This was often reported as challenging, and therefore as inertia against adoption. That is, as was concluded in all three case studies, guarantees and liabilities can positively affect the adoption of modular innovations. 

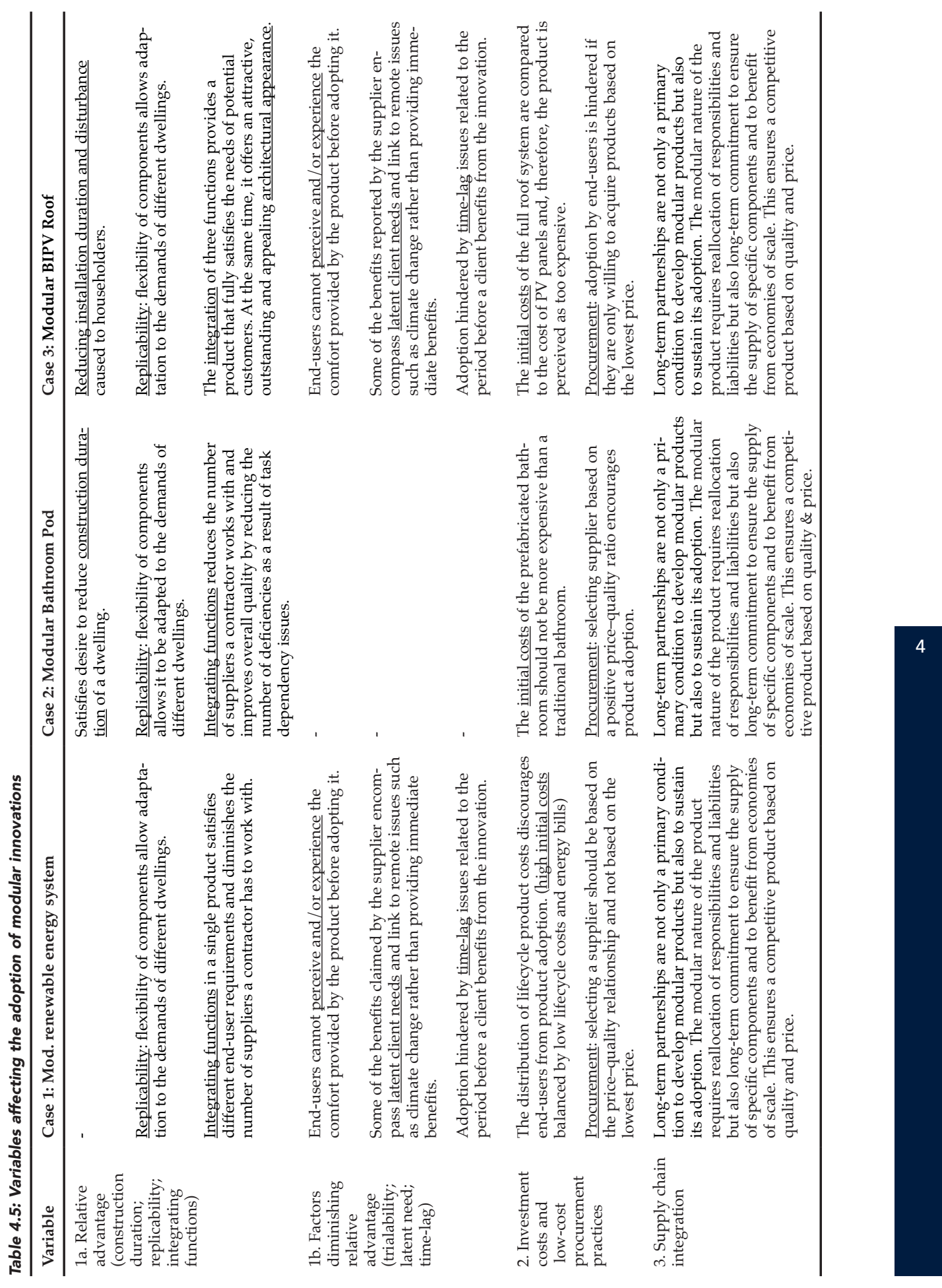

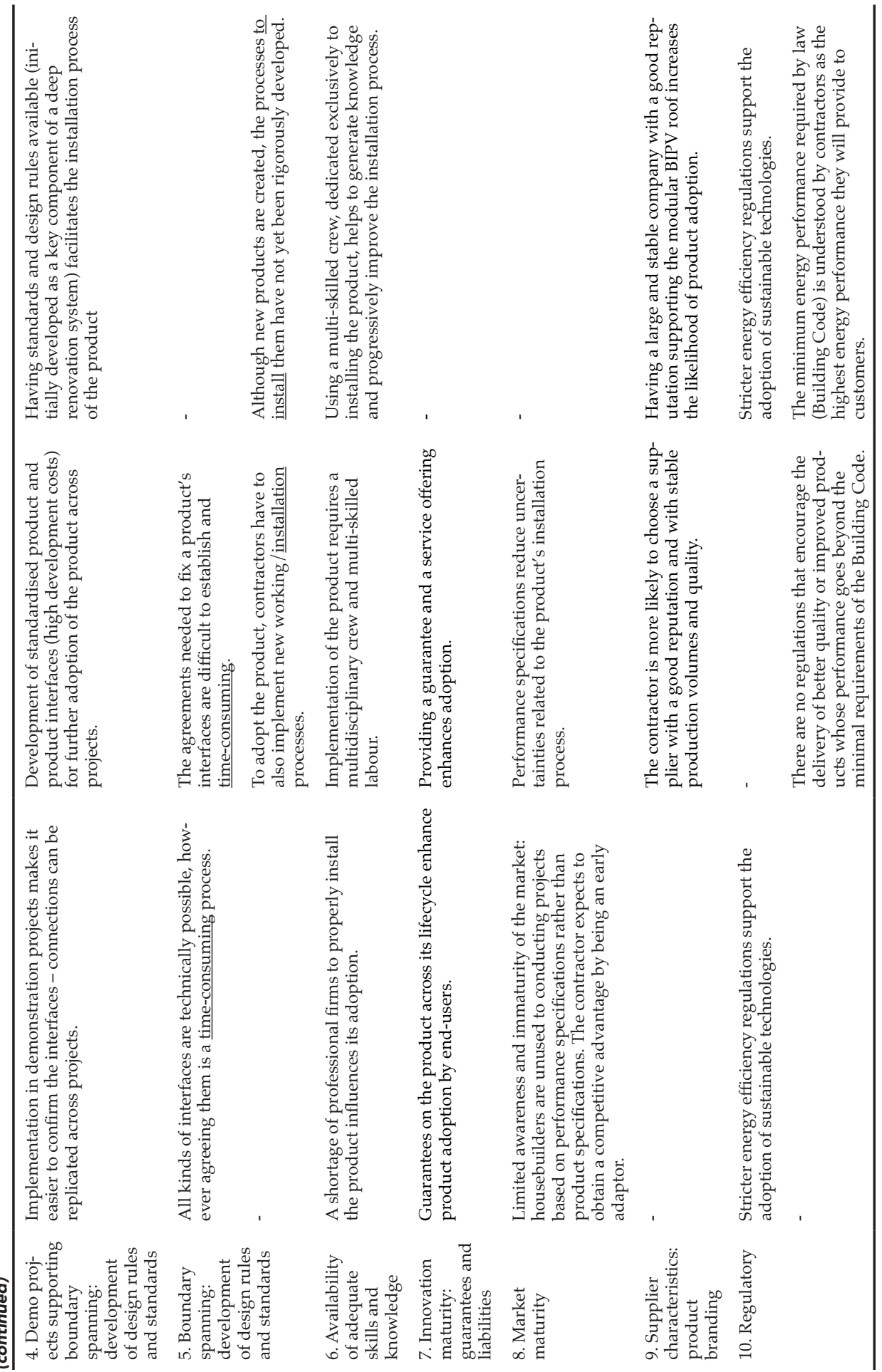

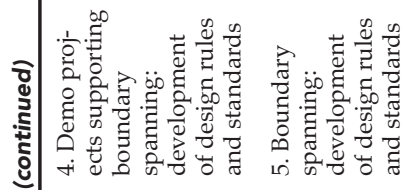
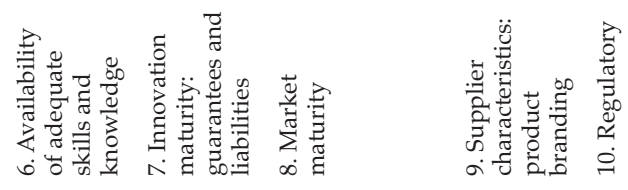


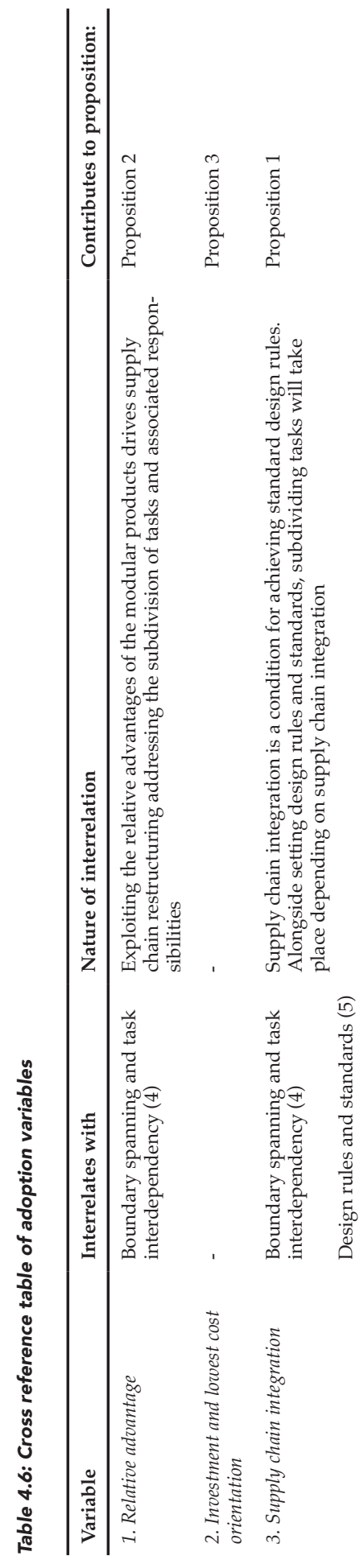

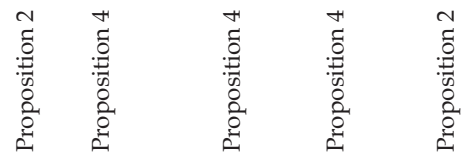

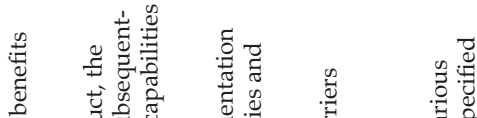

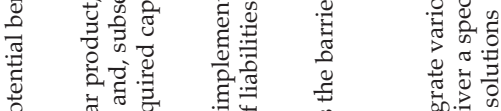

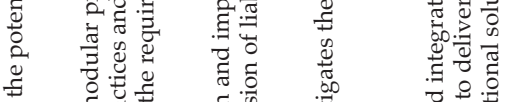

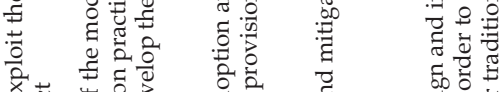

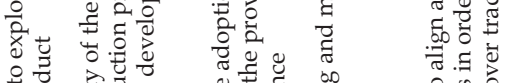

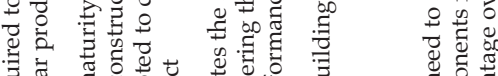

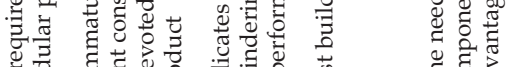

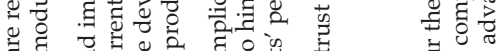

वू.

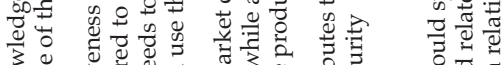

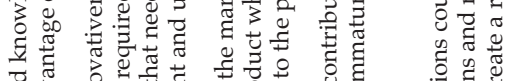

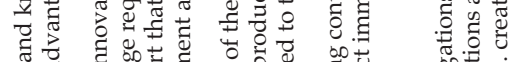

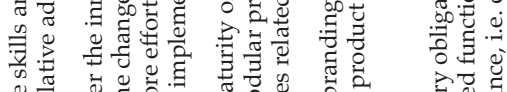

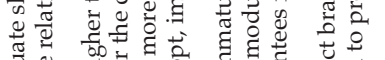

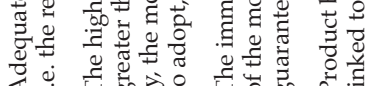

ह

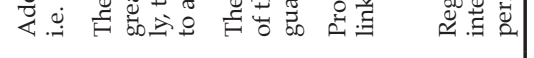




\subsubsection{Deriving key adoption mechanisms for innovative modular products}

As explained in sections 4.3.4 and 4.4.2, we identified, during the process of coding the interview transcripts and carrying out a cross-case comparison, 10 variables that affect the adoption of modular innovations in housing projects. At the same time, we found that several variables were addressed in conjunction with others as shown in Table 4.6. By evaluating the 10 adoption variables and the interrelationships between them across the three case studies, four causal mechanisms were deduced that determine the potential adoption of modular innovations in housing projects. This subsection further explains these causal mechanisms in formulating associated propositions.

[Proposition 1a]: Stable, long-term supply chain integration has a positive effect on the development and adoption of innovative modular products. (see also Figure 4.1).

[Proposition 1b]: A modular supply chain guided by design rules and standards has a positive effect on the continued adoption and diffusion of innovative modular products (see also Figure 4.1).

By developing collaborative relationships between buyers and suppliers in the value chain, a firm can help position itself in the market (London and Kenley, 2001). However, collaboration with stakeholders is only effective if projects are not approached as one-off efforts. In the housing sector, modular products could replace stakeholders traditional arm's-length relationships with relationships based on partnering and collaborative working, i.e. by building closer network ties (Hofman et al., 2009). Brusoni et al. (2001) claim that building houses in a modular manner, by integrating modules of different suppliers, should require less conscious managerial efforts if they comply to design rules appropriate for modular architecture. However, design rules and standards first need to be developed and established, which can be rather complex. In the three case studies conducted, modularisation and function integration required significant managerial effort because design rules had not yet been clearly established. As was emphasised by the respondents in our case studies, establishing close network ties and subsequently developing design rules and standards is very complex. This supports the view that industry fragmentation, and in particular task interdependency and strong boundaries between trades, complicates the development of design rules and standards, and consequently influences the adoption of modular products (Taylor, 2005).

Participants also highlighted that, in order to develop design rules and standards, stable relationships originating in regular communication based on trust and transparency were needed. This indicates that success in developing design rules relies on collaborative work practices which, at the same time, depend on a conscious willingness by stakeholders to invest resources in developing these relations. This is only possible if the adopters have the appropriate motivation and innovative culture within their organisations. 
Overall, if these boundary spanning conditions are not met, it is unlikely that design rules and standards will be established. When boundary spanning activities are successful, and result in design rules and standards, they contribute to less managerial effort being required to implement the modular products in subsequent projects, and thus have a positive effect on adoption. However, establishing an initial agreement about design rules and standards is time consuming and subsequently hinders adoption of the modular product in its early stage of diffusion. In terms of Fine et al.'s (2005) modularity concept, the development of supply chain modularity, in particular in terms of economic organization (network), mode of governance (partnering), cultural proximity (community based); customer order specification (modify to order), is a precondition for full product and process modularity.

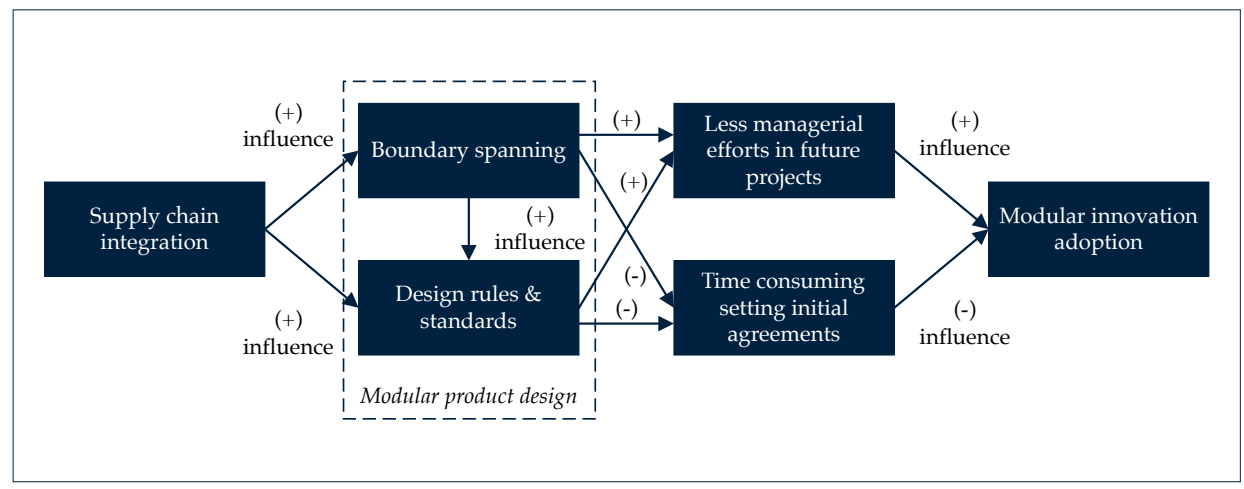

Figure 4.1: First proposed causal mechanism influencing modular innovation adoption.

[Proposition 2]: (a) a Relative Advantage (RA), particularly one reflecting process efficiency gains, has a positive effect on adoption. (b) However, an inability to reshape the supply chain has a negative effect on adoption and moderates the positive effect of an RA. (c) In the same way, the absence of adequate skills and knowledge has a negative effect on adoption and moderates the RA's positive effect (see Figure 4.2).

Hofman et al. (2009) found four contingent drivers in the alignment between product modules and contractor-supplier relationships: the degree of variety in customer demand; the extent of the required supplier investment; the extent of the dependence on supplier knowledge; and the intentions of both the supplier and the buyer in a relationship. Here, we particularly found support for the last of these drivers. Our multiple case study revealed that the design of a modular product with integrated functions improves the overall product's quality but at the same time requires a restructuring of the supply chain. Function integration forces contractors to displace attributions and responsibilities to the supplier. To illustrate this, we use the modular BIPV roof where the contractor, by adopting the modular product, should only need to make agreements with a single supplier of the complete roofing solution. Traditionally, they would have had to make individual and 
separate agreements with suppliers of PV panels, insulation material and skylights. This restructuring of the supply chain has two consequences: first, contractors might be forced to collaborate indirectly with component suppliers with whom they would normally not collaborate; second, contractors might show resistance to displaced responsibilities and loss of control of operations. Therefore, we conclude that the alignment between product modules with integrated functions and contractor-supplier relationships is in part driven by the willingness of the contracting company to accept a different set up of the supply chain. In line with Fine's modularity concept, if the involved stakeholders are not able to align supply chain modularity with product and process modularity, it is unlikely that the modular product will be adopted in housing projects. This seems to be at odds with the primary reason for the development of the modular products in all three case studies: whilst complying with stricter governmental policies and regulations, housebuilders will be able to increase the efficiency of the home building process by combining various components in a single product, thereby reducing the need to process numerous components on site while also improving overall product quality.

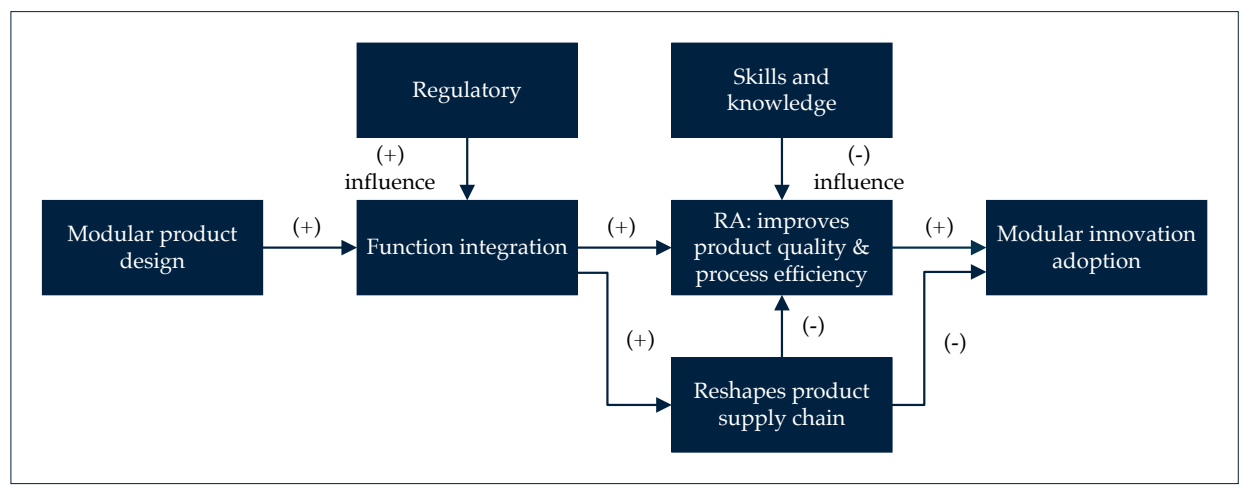

Figure 4.2: Second proposed causal mechanism influencing modular innovation adoption.

[Proposition 3]: The shifts in the product cost structure across the lifecycle of a modular product has a negative effect on modular innovation adoption (see also Figure 4.3).

As has been increasingly studied, the dominant lowest-cost orientation throughout the entire supply chain in the housing sector hinders the adoption of modular products. This is illustrated by the lack of uptake and installation of modular energy efficiency products that would improve a dwelling's energy performance. Here, researchers have found that owners and tenants are reluctant to install these technologies because they give energy efficiency a low priority and further fear cost increases as well as problems with innovative technologies, i.e. the relative advantage of these products is not recognised (see, for example, Hoppe (2012) and Sunikka $(2006,2017)$. Focusing on the supply side of the value chain, our multiple case study has revealed that the reluctance of contractors to adopt innovative modular products emanates from their lowest cost considerations when acquiring and processing products. 
Blismas et al. (2005) argue that the decisions made regarding adopting these products are too often based on costs rather than value.

It would seem that the cost savings possible over the life cycle of modular products is not considered by the stakeholders involved in adoption. To boost adoption, entire life cycle costs need to be emphasised with an understanding of value rather than purely direct material and labour costs (Blismas and Wakefield, 2009). Our case studies similarly revealed that the adopters perceive the modular products as expensive because they do not evaluate the total costs of ownership and that the operational costs savings of the product are not considered at the moment of product acquisition. That is, overall, potential adopters do not always perceive and value the integrated nature of such products. For example, in the case of the modular BIPV roof, potential clients do not always perceive that they would be acquiring not only PV panels, but also improved roof insulation, a sustainable energy system, natural daylight and ventilation, resulting in a comfortable and healthier internal environment. The difficulty in making clients aware of the cost-benefits ratio provided by the product hinders its adoption. As such, this suggests that initial investment costs and low-cost procurement practices have a direct influence on the adoption of a modular product. From a broader perspective, we can also associate the use of traditional procurement practices with an industry that has a traditional culture, a highly fragmented supply chain and one that is resilient to change. Although this cost-based mechanism does not fit directly within Fine's modularity concept, it can be considered a key contingency variable with respect to the innovativeness of the housing sector and its ability to adopt modular innovations (Pero et al., 2015; Sheffer, 2011).

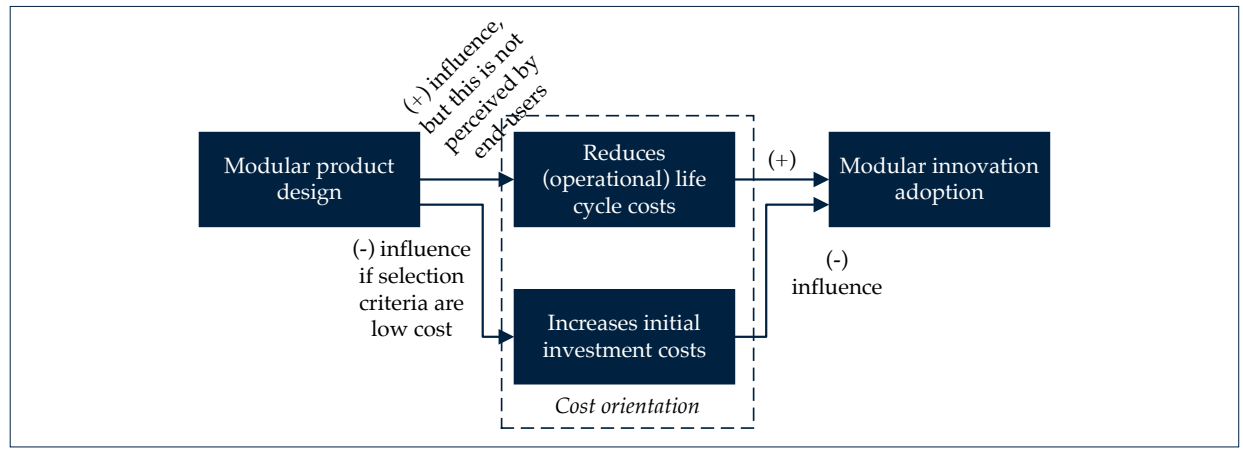

Figure 4.3: Third proposed causal mechanism influencing modular innovation adoption.

[Proposition 4]: Low levels of market and innovation maturity negative effect on the adoption of modular products (see also Figure 4.4).

Trialability and observability are seen as vital for the adoption of innovations (Rogers, 2003). This is problematic when the innovation, like the modular products included in our case study, are in the early stage of market adoption. Intangible benefits, such as low energy bills and improved comfort, are only perceived if they are experienced, and it is 
difficult for potential end-users to experience the benefits of these modular products before purchasing them. The very limited number of installed modular products does not allow early adopters to rely on the experience of previous installed products to inform their adoption decision.

The benefits of sustainable technologies, such as the modular renewable energy system and the BIPV Roof cannot be perceived until the products are installed in the dwelling. As such, the cost benefits from the application of energy efficient technology cannot be perceived until the dwelling is inhabited and operative. Similarly, an increase in comfort or a healthier indoor climate are features of the product that cannot be easily experienced by potential adopters as they are not easily observable. As the added value of the modular innovations considered are improvements in an intangible performance or a new experience, and they remain in an early stage of adoption, suppliers and contractors need to find alternative and innovative ways to let end-users experience the advantages of these products.

Besides the complexity of understanding the performance of modular products due to their current novelty, the suppliers indicate that adoption is further complicated by uncertainties perceived by both contractors and clients about the performance of their modular product. One way to overcome this inertia could be to provide performance guarantees and accept liabilities to gain trust that a modular product is sufficiently mature. However, the unconventional idea of conducting projects based on 'performance specifications', rather than the product specifications normally applied in housebuilding, hinders modular product adoption. Housebuilding contractors are inexperienced and cautious when it comes to working with novel practices.

To summarise, this mechanism underlines the negative effect of product innovativeness on product adoption and the importance of creating mechanisms to overcome this inertia and encourage adoption. These mechanisms relate to both the contingent variable innovativeness of the housing sector and to Fine's modularity concept: not only is the network set up affected but also the division of liabilities and guarantees across the supply chain.

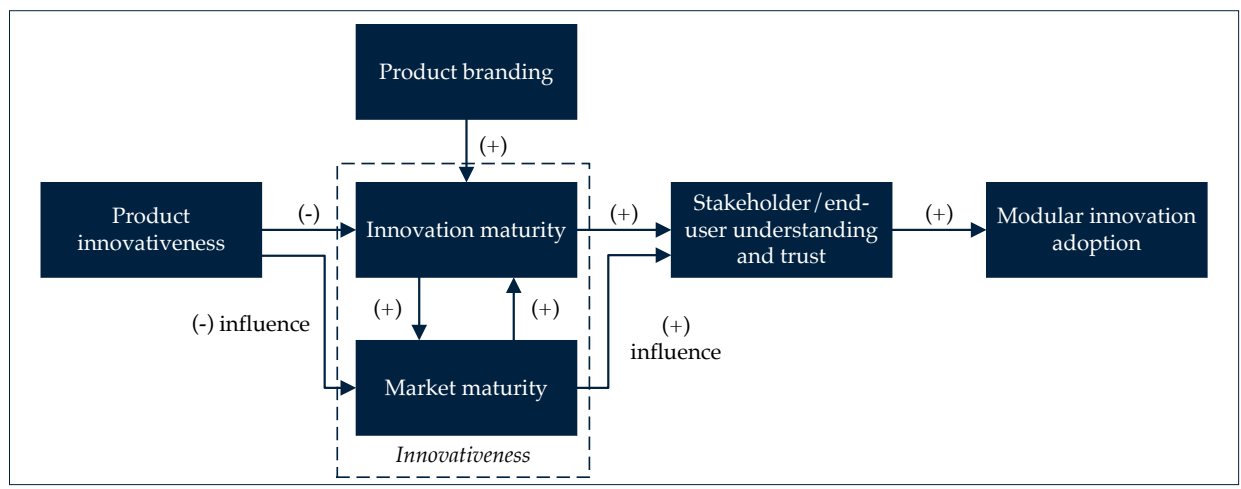

Figure 4.4: Fourth proposed causal mechanism influencing modular innovation adoption. 


\subsubsection{Contribution}

This multiple case study is among the first to study the mechanisms that affect the adoption of innovative, modular housing products. Our multiple case study was guided by two research questions: 1) What are the determining factors in the Dutch housing industry that influence the adoption of modular innovation? and 2) To what extent can the theory on modularity help to explain the adoption of modular innovation in housing? In addressing these research questions, this paper contributes in two ways. First, based on an in-depth assessment of the internal causality of adoption variables, we identified four adoption mechanisms which indicate how and why modular housing products are adopted. Second, our study provides empirical evidence on the effect of modularity on adoption in line with the three dimensions of the modularity concept of Fine et al. (2005) by tying the four adoption mechanisms together in a coherent framework. The findings will be assessed in the remainder of this section.

The three case studies revealed 10 interrelated variables that influence modular product adoption. This led to mechanisms that influence the process of innovation adoption with positive and negative correlations among their variables.

The first proposed mechanism underlines the importance of having an innovative culture inside the company that can 'overcome' the traditional nature of construction companies. Having an innovative culture within a company is a precondition for increasing cross-company collaborative practices. This will provide space to allow the creation of standard interfaces and design rules, aspects which are traditionally considered time consuming, complex to achieve and lacking added value. In its totality, proposition P1 supports the hypothesis that unless the supply chain, the process and the product modularities are congruent, it is unlikely that the overall product architecture will reach a high level of modularity and, consequently, it will not be adopted. Proposition P1 is also supported by previous construction management research regarding the barriers to innovation in construction and housebuilding (Lindgren, 2018; Sheffer, 2011; Taylor, 2005).

The second proposed mechanism, reflects how the integration of functions in a modular product can improve its relative advantage (improved quality and reduced construction time and costs). However, the integration of functions within a modular product also requires restructuring the supply chain. This links to the willingness of a contracting company to make agreements with, possibly new, partners in the supply chain and a willingness to delegate responsibilities to suppliers. As such, proposition P2 encompasses the relative advantage, boundary spanning and task interdependency variables and, in particular, links adoption theory and construction innovation management theory. Proposition 2 is supported by scholars from the field of construction innovation management who found that sector-specific 'structural barriers' constituted by carrying out construction projects 
by temporal coalitions, complicate boundary spanning and overcoming task interdependency issues, which hinder innovation (Lindgren, 2018; Sheffer, 2011; Taylor, 2005). Going beyond P1, proposition P2 reflects that a modular product design also has implications that go beyond establishing a modular organisational supply chain: besides developing a modular product with appropriate standard interfaces and design rules, the organisational structure needs to be aligned and this also requires a clear allocation of liabilities and responsibilities (Cabigiosu and Camuffo, 2012; Colfer and Baldwin, 2016).

The third proposed mechanism shows that innovation adoption is heavily influenced by cost considerations. Benefits provided by the integration of functions in a module intrinsically lead to an increase in the purchase cost of the product. However, adopters do not associate this increment in the initial cost with the delivery of additional benefits (Goodier and Gibb, 2007a; Pan et al., 2008). For example, the cost-saving benefits of modular innovations that reduce operating costs and improve energy performance and the indoor climate are poorly perceived by end-users, hindering their adoption by contractors. In addition, traditional procurement practices do not encourage the adoption of best-value-for-money solutions, but rather look for the lowest purchase costs. Since this proposition cannot be associated with modularity theory, we instead consider it a contingency mechanism linked to innovation barriers apparent in the housing sector (Pero et al., 2015; Sheffer, 2011).

The fourth proposed mechanism, explains how the current immaturity of the modular products, whose added value is difficult for their potential beneficiaries to perceive, prevents end-users from adopting them; thereby hindering product adoption in the industry. The role of the 'technical' maturity of an innovation has been discussed in the innovation adoption literature (Gan et al., 2015; Zhang et al., 2014b). Our research has particularly revealed that innovation maturity, expressed by the availability of guarantees and liabilities, has a positive effect on the adoption of innovative modular products. Further, our research has also shown that 'market' maturity tends to affect the adoption of modular products. This links to capabilities, not directly linked to the modular product, that the housebuilding industry needs to possess in order to adopt and implement the innovation (Egmond et al., 2005; Roders and Straub, 2015; Swan et al., 2017; Swan et al., 2013b). This proposed mechanism links the innovativeness contingency variable and the establishment of an appropriate supply chain with clearly allocated liabilities and responsibilities. As a consequence, the stakeholders need to develop the knowledge and skills necessary to adequately address these responsibilities (this was also implied by the case studies conducted by Wolters (2002)).

As a second contribution, we have provided empirical evidence supporting Fine's modularity framework (Ellram et al., 2007; Fine et al., 2005) and the effect of modularity on adoption. To our knowledge, this is one of the first in-depth empirical studies to explicitly link innovation adoption to modularity theory. Studied through a modularity lens, i.e. applying Fine's three-dimensioned modularity concept, we derived four propositions which mirror four mechanisms determining adoption. 
These propositions fit with and define Fine's modularity concept in the context of the housing sector. From this, we can deduce that the compliance of the product, process and supply chain modularities shape the boundary conditions within which the modular product will potentially be adopted and diffused. At the same time, it defines what is required to cross boundaries and get the modular products adopted in other housing systems and projects. This corresponds to the findings of Voordijk et al. (2006) on the effect of 'territorial economics' (Dicken and Malmberg, 2001) on the application of modular housing products. In practice, this means that innovative modular products, at least in their early stages of diffusion, are most likely be adopted and applied in housing projects constructed by stable coalitions of supply chain partners, see Figure 4.5 (Bygballe et al. (2015); Bygballe and Ingemansson (2014); Gadde and Dubois (2010); Gann and Salter (2000)). A managerial implication of this finding is that innovative firms could apply the framework and propositions to improve the adoption potential of modular products in the early stages of market entry and market formation.
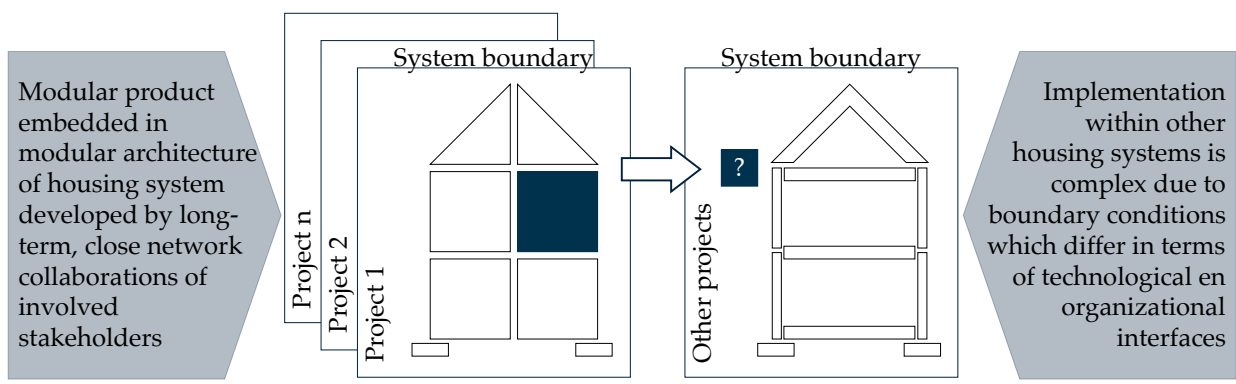

Figure 4.5: The system boundaries of a modular housing system hinders the adoption of modules in other projects and housing systems

\subsubsection{Limitations and future research}

This study is not without its limitations. Although the findings are based on an extensive literature review and three case studies, additional empirical data are required to generalise the findings. To this end, future research could usefully focus on testing the identified mechanisms affecting the adoption of innovative modular housing products in a large-scale study. A second limitation is that only a single market, namely large-scale housing projects in the affordable (i.e. low-cost) housing market in the Netherlands, has been studied. Future studies could extend the research to other market segments and to housing projects in other countries and use cross-national data to account for differences in institutional structure. From academic, managerial and policy perspectives, addressing the future research opportunities described above could make an important contribution. 


\subsubsection{Conclusion}

This research contributes to the existing body of knowledge concerning the possibilities to utilise modularity concepts in the construction industry. By conducting an extensive literature review and a multiple case study we have identified four determining adoption mechanisms. These mechanisms support previous research findings that suggest that, when products become modular, the production process and the supply chain need to move in a similar direction. Moreover, the four identified adoption mechanisms led to the hypothesis that the adoption of modular housing products depends on coherence between the three dimensions of modularity. Furthermore, the study offers propositions that can be further explored and confirmed in large-scale studies across various sectors and industries to increase understanding of preconditions for successful modularisation.

Acknowledgement: The authors would like to thank Rudolph Jauregui Becker for his great work during collecting and analysing all the data. 



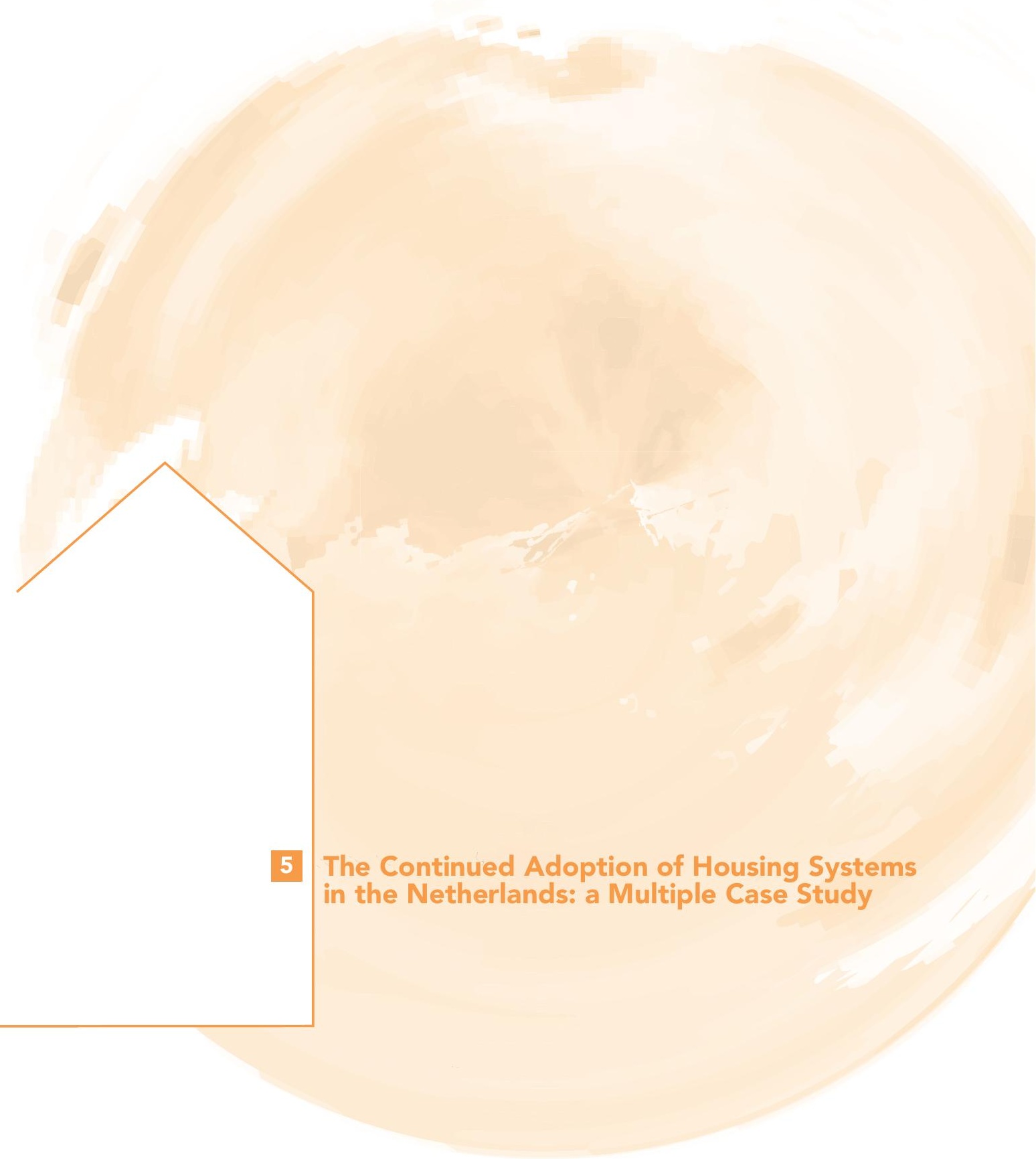




\section{(aid)}

5 The Continued Adoptic
a Multiple Case Study

This chapter has been published in Journal of Construction Engineering, Management \& Innovation ${ }^{15}$

\section{Abstract}

Extensive governmental and industry efforts have been devoted to developing innovative housebuilding systems. However, it appears a challenge for housebuilding firms to move beyond their demonstration status and get their housing system adopted at a large scale and over a longer period. This is problematic since worsening developments concerning the environmental impact, poor production efficiency and a lack of client orientation of traditional building practices remains unsolved. This article describes a multiple case study on the continued adoption of innovative industrial housing systems. The multiple case study centres around a housing system which is generally considered as a rare example of an industrial housing system that has succeeded in the last 30 years in maintaining a leading position in the Dutch housing sector. This article analyses the reasons for this continued adoption in contrast to three industrial housing systems which had to abandon the market. The case study findings show that at least five mechanisms play a determining role in the eventual continued adoption: the regional presence of the builder; the builders' operational excellence; a natural fit with existing technology standards; a competitive added value, and; the ability of the house-builder to keep pace with changing market requirements. An important lesson from this study is that, for continued adoption, one needs to stay alert and adapt the housing system to changing market requirements.

15.Van Oorschot, J.A.W.H., Halman, J.I.M., \& Hofman, E. (2019). The continued adoption of housing systems in the Netherlands: A multiple case study. Journal of Construction Engineering, Management \& Innovation, 2(4), 167-190. 


\subsection{Introduction}

In recent decades, extensive governmental and industry efforts have focussed on developing and constructing sustainable, industrialized and customer oriented solutions for the housing market (see for examples e.g. Banfill \& Peacock (2007); Egan (1998); Gann (1996); Ozaki (2003)). Despite several efforts, it appears a challenge for house building firms to move beyond their demonstration status (Femenias, 2004; van Hal, 2000) and get their housing system adopted at a large scale and over a longer period.

Nevertheless, exceptions do exist, as is the case with the W\&R Housing system pertaining to the Royal BAM Group in the Netherlands. W\&R, a Dutch abbreviation, expresses two core values of the housing system: it provides high quality and spacious housing units. This housing system combines an efficient on-site method to construct the load-bearing system with a growing number of add-on prefabricated elements as a result of increased prefabrication and variation. This system was firstly introduced in 1992 in the Dutch housing market. Since its introduction in 1992, almost 20,000 housing units were delivered so far. This raises the question why the W\&R housing system succeeded to keep its strong market position in the Netherlands for such a relative long period while many other attractive housing systems did not survive.

Although a literature search revealed a substantial body of literature about housing innovation adoption, informative literature about continued adoption over a longer period in time and across various housing projects appeared to be very limited. An understanding of the factors affecting the continued adoption of a housing system is nevertheless essential for scholars studying the determinants of continued adoption as well as for the creators and producers of such housing systems. Also knowledge about the reasons behind a discontinued adoption can be considered as crucial since industrial housing systems are found key to address several worsening developments in the housing sector, in particular regarding a growing housing shortage (ECSO, 2017, 2018a, b). This article therefore attempts to contribute in closing this gap in literature by answering the following two research questions:

1. What differentiates the WER housing system from housing systems, which did not experience a continued adoption?

2. Which mechanisms contribute to a continued adoption over time and across housing projects?

The overall aim of this research has been to unravel the mechanisms which shape the potential continued adoption of industrial housing systems in the Dutch housing sector. The research questions have been addressed by conducting a longitudinal case study of the W\&R housing system and a robustness check by comparison of the findings with three less successful industrial housing systems. 
To our knowledge, this is the first study that encompasses a longitudinal case study about the adoption of a successful industrial housing system which has been continuously adopted across various projects over time, relative to three competitive housing systems which abandoned the market.

The rest of this article is structured as follows. Based on a literature review, we define in section 2 the concept of a housing system and explain why it is important that innovative and industrial housing systems are adopted at a large scale across projects. In section 2 also the literature about 'continued adoption' will be discussed. In the third section, we provide details about the different research steps that we followed when conducting this study. In the fourth section, the research findings are presented including the successive phases in the lifecycle of the W\&R housing system and the stage-gated adoption process when selecting housing systems. In the fifth section, a comparison is made between the W\&R housing system and three other housing systems that did not survive in the market after an initial successful adoption. Based on the case study material, this section also deduces a number of critical mechanisms that secure a continued adoption of housing systems. Finally, the last section discusses the scientific and managerial contributions and possible directions for future research.

\subsection{Literature review}

Industrial (house)building (IB) aims at raising efficiency by rationalising the construction process through the adoption of production technologies and methods found in highly industrialized mass-production industries like automotive. In the past decades various IB methods have been developed. These IB methods are often addressed as 'modern methods of construction'. They range from industrialized on-site construction methods to the off-site production of volumetric pods (Hartley and Blagden, 2007; NAO, 2005; NHBC, 2016; Ross et al., 2006; Taylor, 2010). The three underpinning characteristics portraying the essence of IB are standardisation; prefabrication, and; system building (Zhang et al., 2014b). Standardization is considered a prerequisite for the application of industrial production processes, both on- and off-site (Gann, 1996; Lessing et al., 2005). The predominant application of industrialised production methods is usually off-site prefabrication (Gann, 1996; Gibb, 2001). However, industrialized house building could also include site-based methods while still applying industrialised design and production principles (Thuesen and Hvam, 2011). The term 'systems building' has been introduced to describe a set of building components which are linked together and that require a well-coordinated system of technical and organizational interfaces (Finnimore, 1989; Gann, 1996; Vogler, 2016). Based on these general characteristics an industrial housing system (IHS) can be defined as: the application of mass-production principles to construct housing. Industrial housing systems involve on- and off-site production methodologies within a controlled environment, and delivered through a well-coordinated integrated system (Blismas et al., 2010; Grimscheid and Scheublin, 2010; Hamid et al., 2008; Kamar et al., 2009). 
Despite the reported benefits, many industrial housing systems are hardly applied beyond their demonstration status across a range of subsequent projects, i.e. 'the history of IB is rich in examples of failures' (Arif and Davidson, 2009; Lind, 2011). This discontinued adoption is problematic, since the housing market, clients and industry alike, do not benefit from the potential of industrial building practices (Goodier and Gibb, 2007b; Grimscheid and Scheublin, 2010; Pan et al., 2007, 2008; Rahman, 2013; Thillart, 2004). It may be considered as a missed opportunity, since industrial housing systems have been identified as an important condition for solving worsening developments in the housing sector such as labour and skills shortage (ECSO, 2017); significant housing shortage (ECSO, 2018b) and a detrimental environmental impact (ECSO, 2018a).

Many innovations seem to fall into a chasm after they have been adopted by early adopters in the market (Egmond et al., 2006b; Matinaro and Liu, 2015; Naney et al., 2012) and subsequently fail to be adopted beyond demonstration projects (Brown and Hendry, 2009; Femenias, 2004; van Hal, 2000). In particular in the construction and housing sector, demonstration projects are considered a key vehicle to innovation and change, while they create environments for R\&D and learning (Bossink, 2015, 2017; Bossink, 2004; Brown and Hendry, 2009; Heiskanen et al., 2015). Despite to the importance of demonstration projects with respect to innovation in the construction and housing sector, only few explorative studies, which tend to focus on sustainable building, have been conducted to research the adoption and implementation of innovation in demonstration projects and beyond (Femenias, 2004; Haavik et al., 2012; van Hal, 2000).

Regarding the adoption of sustainable innovation, Van Hal (van Hal, 2000) identified four interrelated variables affecting adoption beyond demonstration: 1) quality of the innovation; 2) organization of the demonstration project; 3 ) organization of the information transfer, and; 4) influence of the government. First, a demonstration project only contributes to subsequent adoption if it proofs that the innovation is of sufficient quality and has commercial potential. Second, also the project organization is key to subsequent adoption. It has been found that inter-disciplinary cooperation and the involvement of an innovation champion are increasing the chance of further adoption. Third, the absence of a properly organized information transfer has been identified as a key barrier to adoption in subsequent projects. Research results showed that information transfer must centre around unambiguous and uniform evaluations and must target different stakeholder groups in the industry. The importance of a change agency (public authority), responsible for knowledge dissemination across the industry has also been emphasized. Fourth, Van Hal showed that the government, as a regulator, initiator, stimulator and change agency, could substantially impact the change of adoption beyond demonstration. 
Research conducted by Femenias (2004) reveals that the poor effect of demonstration projects to the wider uptake of innovation can be attributed to: 1) lack of incentives and interest to learn from experience; 2) lack of compilation and dissemination of reliable and useful findings; 3 ) a gap between the ideals of the demo projects and the ideals of involved stakeholders, and; 4) the perception that demo projects are considered as being special projects and side-tracks from mainstream building.

Despite the above noted valuable insights about a continued adoption of an industrial housing system beyond its demonstration phase, some important research lacuna's can be identified. First of all, the uptake of innovations like industrial housing systems are found to be intrinsically linked to project procurement (Murphy et al., 2011; Murphy et al., 2015). Current research did not yet bridge the gap between project procurement and innovation adoption theory (Dainty et al., 2005; Keegan and Turner, 2002; Murphy et al., 2011). Second, longitudinal case studies focusing on the adoption of innovation across projects over time are scarce. In particular studies which study the extend adoption determinants that change over time are limited (Mitropoulos and Tatum, 2000; Mustonen and Ollila and Lyytinen, 2003). Third, there is a lack of empirical data about why some innovations fail to be adopted across projects relative to successful competitive alternatives as can be found in the field of industrial housing systems. This research aims to close these gaps by conducting a multiple case-study.

\subsection{Research Method}

\subsubsection{Research method and sample}

An in-depth case study aims at providing insight into a phenomenon of interest and contributes to theory building. A multiple case study extends an in-depth case study to examine multiple cases where the focus is both within and across cases (Yin, 2003), and as a result can deepen the understanding of the phenomena (Miles and Huberman, 1994). A multiple case-study also provides the ability to generalize findings to a broader range of situations through appropriate case selection and cross-case comparison (George and Bennet, 2005; Miles and Huberman, 1994; Miles et al., 2014; Yin, 2003) . Therefore, this multiple case study encompasses four industrial housing systems. The four case studies share a specific feature: they all apply alternative but proven industrial building methods in contrast to traditional housebuilding. The four cases have in common that they apply a standardized housing design and/or a standardized housebuilding process in order to make industrialization and the application of modern construction methods possible. These industrial building methods include both on- and off-site technologies, but in all four cases off-site produced, prefabricated building components are used. Yet the four case studies most differ from each other with respect to our research interest: continued adoption. Of these four housing systems only one, the WER system (further referred to as "W\&R"), has experienced a continued adoption over a long period of time. Therefore 
WER was selected to be studied longitudinally. W\&R was developed by the Royal BAM group (further referred to as "BAM"). BAM is the largest contractor in the Dutch construction sector. Since the initial development of W\&R in 1990 and the first delivery in 1992, several upgrades, in terms of both product and process improvements have been realized. These improvements were largely motivated by changing market conditions. With over 20,000 W\&R dwellings erected since 1992, W\&R became a market leader in The Netherlands in the supply of newly constructed houses. In addition to the W\&R case and as a robustness check of our findings (cfm. George and Bennet (2005) and Gerring (2007)), we compared W\&R with three less successful industrial housing systems: the Concrete Slab housing system; the Wooden Frame housing system and the Steel Frame housing system $^{16}$. These three cases were selected from a larger pool of industrial housing systems which abandoned the market applying the following inclusion criteria: a) the housing systems were applied in the same housing market segment; b) they had relatively recently abandoned the market and; c) key stakeholders involved with the housing system could be identified and were willing to participate in the case study.

\subsubsection{Data Collection and Analysis}

The data collection and analysis for this study was conducted in six phases. The aim of the first phase was to gain an understanding of the process of adoption and diffusion of innovations in general, and more specifically, of the development and implementation of industrialized housing systems. Consequently, the relevant adoption and diffusion literature was reviewed. From this we learned that continued adoption, i.e. the adoption of housing innovation in various projects over time, has hardly been selected as a topic for further analysis. During the first stage of this study, also 15 exploratory interviews with various actors in the housing market, such as social housing associations, project developers, architects, contractors, municipalities and researchers, were conducted. The interviewees were explicitly asked about existing industrial housing systems and the market perspectives for industrial housing systems. This step guided the selection of the four housing systems to be researched in our multiple case-study.

The second phase consisted of the selection and interviewing of 17 professionals who have played a key role in the adoption and diffusion of W\&R in the Netherlands. In depth interviews with these key actors served to develop an understanding of how W\&R managed to remain competitive and successful for already more than 25 years. The focus in the interviews was on: (1) gaining insight into how the decision-making process of selecting and adopting novel housing systems takes place; (2) uncovering the unique characteristics of $W \& R$ as a rare example of an industrial housing system that has been able to sustain itself, and; (3) identifying the specific reasons for selecting W\&R and rejecting alternative housing systems.

16.The names of the housing systems have been altered and reflect the core design of the industrialized housing system. 
In addition to these interviews, we also conducted in depth interviews with the key actors involved in the adoption and diffusion process of the Concrete Slab housing system, the Wooden Frame housing system and the Steel Frame housing system. The average duration of all the interviews was about 1.5 hours. The interview protocol was adapted to each interviewee's specific role in the decision-making network and the contextual setting. To avoid excluding important issues, the respondents were also asked to add any influencing factors that had not been addressed and which they thought to be relevant for the decision outcome to adopt. If possible and with the permission of the respondents, the interviews were recorded, and the recordings were used in transcribing the interviews. Further, interviewees were asked to provide documents or other written or electronic material to illustrate or complement their statements, and these were used as additional sources of data.

In the third phase, a content analysis of the interview reports was undertaken using ATLAS.ti. 6.2. In line with the procedure for content analysis recommended by Boeije (2010), every document was 'open coded'. In the next step, through 'axial coding', the case study data was reorganized and reassembled. This was then used as input for 'theoretical coding', where relationships between data fragments were identified in order to explain the nature of adoption decision-making. Point of departure of this analysis was the close examination of how and why the housing system of interest was adopted. This revealed how clients select a housebuilder and which considerations are key to adoption.

During the fourth phase a cross-case comparison was conducted following Miles and Huberman's interactive model of data management and analysis (Miles and Huberman, 1994; Miles et al., 2014). After coding the interview transcripts, data was displayed by constructing four separate in-depth case study narratives including a series of supporting figures and tables. The output of the four case studies were subject to cross-case analysis following the recommendations of Miles and Huberman (1994) and Miles, Huberman and Saldana (2014). The cross-case analysis encompasses a variable-oriented approach where variables are compared across the four case studies. The case specific determinants are compared with each other to arrive at generic mechanisms. These generic mechanisms are constructed following several iterations of re-examining the case data and completing the cross-case table (see Table 5.2).

In the fifth phase, the case study findings were processed and synthesized in a scientific report that was discussed with the W\&R Management Team and the former directors of the Concrete Slab, Wooden Frame and Steel Frame housing systems. The management team and directors confirmed the case study findings as an accurate description of the adoption and diffusion of their respective housing system. During the meeting with the W\&R Management Team, also the plans and prospects for the W\&R approach were discussed.

Finally, a workshop, annexed to a symposium, was organized in which the results of this study were presented. Over 60 people, all active in the housing development market and including most of the interviewees, attended. The debates were taped and then analysed following the same content analysis procedure as with the interview transcripts. 


\subsection{The Stage-Gate Selection Process}

The W\&R case study showed how the adoption of an industrial housing system is intrinsically linked to project procurement following a stage-gate selection process. During successive steps house-building firms and bids are evaluated and selected until one bid remains. In this section, we explain the successive steps in the stage-gate adoption decision-making process that are applied by clients when selecting their preferred builder for a housing project. This will also provide insight about essential criteria that suppliers of innovative housing systems in the Netherlands should meet to be considered as acceptable for social and commercial property developers in their role as investor and client.

There are three types of clients for W\&R houses: social housing associations; commercial investors; and the AM Property Development (AMPD), an in-house commercial property developer belonging to BAM. Of the 20,000 housing units constructed so far, about $50 \%$ result from in-house projects, $30 \%$ link to social housing projects and the remaining $20 \%$ constitute commercial house building. Typically, the clients of W\&R are involved in large-scale single-family housing projects, which define the low-end housing market and occasionally housing for the middle class sector in The Netherlands.

In the planning process to build houses on a specific parcel, social housing associations and commercial property developers, have to determine the number and type of houses to build. In this decision-making process, the developers have to comply with prescriptions laid down by the local municipality. For example, a municipal zoning plan may prescribe the dimensions of individual plots, or the type and number of houses and other buildings that may be built in a specific area. Thus, land availability and planning issues have a great effect on creating demand for housing systems like W\&R. In addition, planning decisions of social housing associations are guided by social housing policies of the Dutch government, i.e. the investment costs of the project need be recovered primarily by rent, for 2019 limited at $€ 720,42$ monthly.

To realize their building plans, housing associations and commercial property developers also have to select a house-building firm with whom to realize a project and whose housing system they will adopt. The selection and procurement of a house-building firm can best be characterized as a stage-gate process. The process starts with an invitation to one or several potential building companies to make an offer. Each stage ends by weighing and filtering the alternative propositions made by the various companies. This filtering process is organized in such a way that a property developer is eventually able to select the most attractive housing system and building company to realize the project. The interviews with professional clients undertaken as part of this study showed that adoptions occur through a three-stage selection process: contractor selection, price selection and selection based on added value to the project (see Figure 5.1). 
Two procurement strategies, competitive tendering and negotiated contracts, are found dominant in the low-end housing market. The former is more accustomed during periods of economic downturn to benefit from lowest price guarantees. Best-value procurement based on selective procedures has gained importance although these tenders tend to be dominated by lowest price considerations. In practice, 'best value for money' bids have a disadvantage due to a lack of instruments to value other qualitative aspects of the bid. Note that, according to Dutch Law, social housing associations are not seen as public institutions and are therefore not obligated to organize a public competitive tender (as long as projects are limited to housing). As a result, housing associations also apply negotiated contracts by inviting one or several contractors. Despite the differences between various tendering strategies, it seems that clients take into account the same set of considerations to evaluate the bid of industrial housebuilders. Even in the case that only one house builder is invited, the bid is assessed by the same set of criteria in the order as can be found in the stage-gate process in which lowest cost consideration dominate. Table 5.1 provides an overview of the key considerations clients take into account when selecting a housebuilder. These considerations are confirmed by literature in the field of tender evaluation and contractor selection (Cheaitou et al., 2018; Holt, 2010; Watt et al., 2009; Yang et al., 2016). However, research in this field in particular still lacks empirical evidence about how contractor and tender selection criteria are evaluated by clients in case of deciding whether or not to adopt an innovation within a housebuilding project (Murphy et al., 2011). It becomes interesting to learn why $W \& R$ has been and still is repeatedly selected in housebuilding projects, and why competitive alternatives failed to pass the stage-gate selection process.

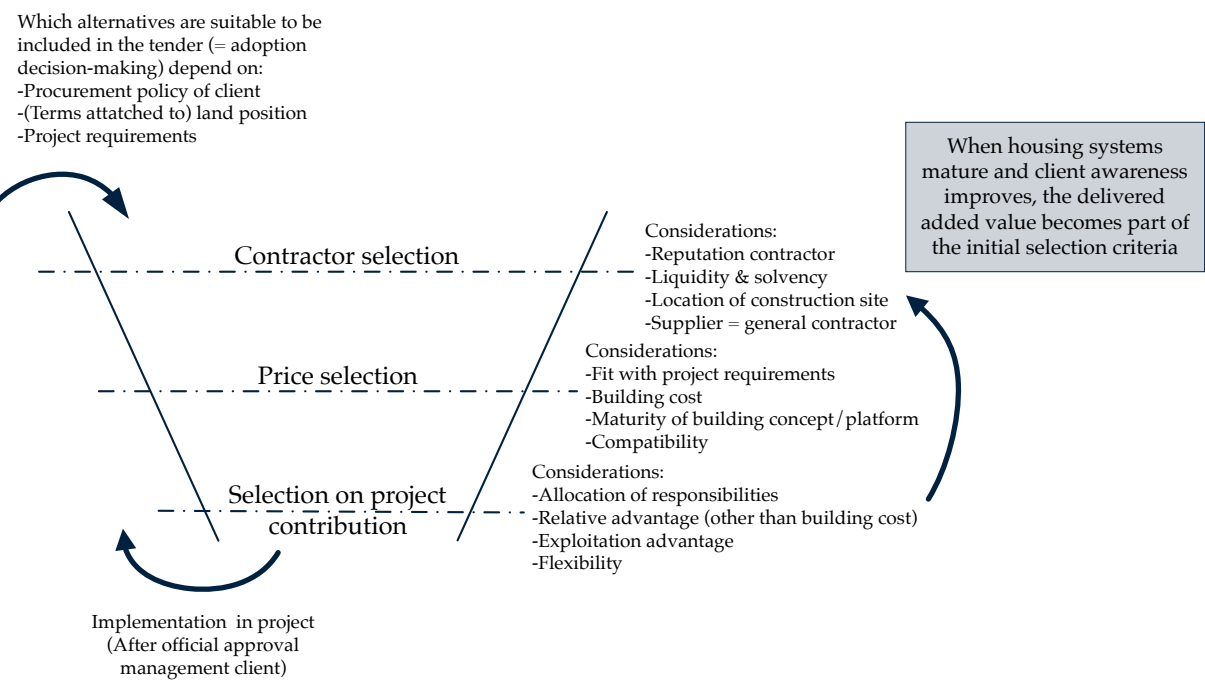

Figure 5.1: The stage-gate decision making process for realizing housing projects in The Netherlands. 
Table 5.1: Client considerations during the stage-gate decision-making process

\begin{tabular}{|c|c|}
\hline Stage of selection & Considerations by client \\
\hline $\begin{array}{l}\text { 1. Contractor } \\
\text { Selection to } \\
\text { Participate in the } \\
\text { Tendering Process }\end{array}$ & $\begin{array}{l}\text { 1. Which house-building firms are expected to be able to complete the project } \\
\text { successfully? } \\
\text { - Have acquired experience as main contractors - as well as consultant - with } \\
\text { respect to certain type of projects (i.e. new build houses or retrofitting projects); } \\
\text { - Provide guarantees with respect to working conditions, quality and environment } \\
\text { c.q. sustainability; } \\
\text { - Have developed certain capabilities with respect to innovation and supply chain } \\
\text { integration; } \\
\text { - Have developed certain capabilities with respect to performance-oriented project } \\
\text { delivery; } \\
\text { - Have developed certain capabilities with respect to client orientation; } \\
\text { Are willing to share all information, i.e. to show transparency in the way busi- } \\
\text { ness is conducted; } \\
\text { 2. How trustworthy is the house building firm based on experiences in previous projects? } \\
\text { 3. Are active within the region of the construction site; Which house-building firms are } \\
\text { active in proximity of the intended building site? } \\
\text { 4. Which of these house-building firms can be considered as viable, given their liquidity } \\
\text { and solvency positions? } \\
\text { 5. With respect to the proposed housing systems delivered by the house-building firm: } \\
\text { - Is the housing system supplied by a house-building firm with a reputation gene- } \\
\text { ral contractor (in contrast to for example an architect or component supplier)? } \\
\text { - Is the housing systems considered sufficiently mature? }\end{array}$ \\
\hline $\begin{array}{l}\text { 2. Contractor } \\
\text { Selection on Price } \\
\text { / Best Value for } \\
\text { Money }\end{array}$ & $\begin{array}{l}\text { Considerations about the tender (quantitative): } \\
\text { - Does the bid encompass all the functional project requirements? } \\
\text { - Is the bid financially transparent and complete? } \\
\text { - Does the bid fit within the project's budget? }\end{array}$ \\
\hline $\begin{array}{l}\text { 3. Additional } \\
\text { Value against } \\
\text { Lowest Price }\end{array}$ & - Which bid in terms of quality and service offers the best added value? \\
\hline
\end{tabular}

\subsection{The W\&R Housing System}

This section provides a detailed overview of the steps that were taken to adapt W\&R in the last 30 years to changing market developments and requirements. In the course of time, adoption criteria have been extended or further tightened in order to meet new requirements such as with respect to sustainability and energy performance. Subsequently we focus on the incremental innovation process steps that W\&R followed to keep its attractiveness over time and which subsequently led to its continued adoption.

W\&R was introduced to the Dutch market in 1992. Since its introduction, over 20,000 W\&R houses have been built in the Netherlands across 300 different projects. Figure 5.2 shows the yearly number of completed W\&R dwellings since 1992. One may observe a downward trend since 2008. This was due to the economic crisis (2007-2016) that emerged in the construction industry in the Netherlands, and which resulted in a severe annual decrease in housing production. However, since 2016, housing production increased again and a further increase is expected for the coming years. 
Number of dwellings produced using the W\&R housing system

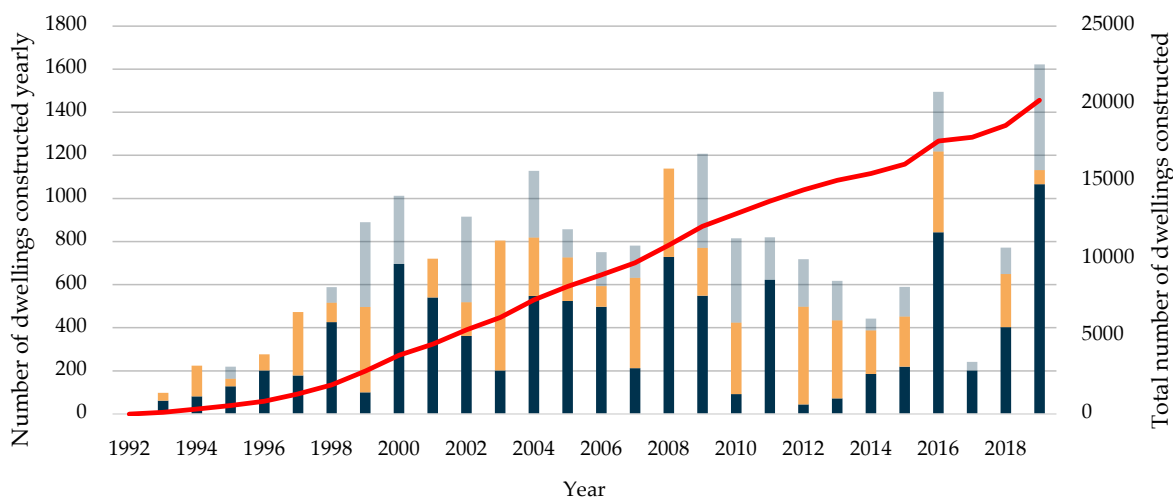

Prefered supplier in-house project development Social housing

Commercial house building

Total volume of dwellings produced

Figure 5.2: The Number of constructed dwellings by the W\&R housing system since 1992

\#Note that a severe decline can be noticed in 2017 relative to 2016 (due to administrative issues - several projects started in 2016 and were completed in 2017 but were nevertheless administrated in 2016)

In the last 25 years, the W\&R housing system has proven to be a serious selection option for social housing associations and commercial property developers with low-cost and middle-class houses in their development plans. To accommodate the changing and tightening requirements demanded by these professional clients in the last few decades, the $W \& R$ housing system underwent a series of adaptations. So far, three main phases of adaptation of $W \& R$ can be identified: 1 ) a process of product and process standardization; 2 ) the creation and implementation of a standardized range of housing solutions, so called "standardized variety", and; 3) the development and implementation of a differentiation strategy by offering housing solutions targeted at different market segments. Currently, W\&R seems to be entering its fourth phase, which can be characterized by the inclusion of service-oriented components. Figure 5.3 provides an overview of the successive adaptations of the W\&R housing system since its early introduction in 1992 in the Dutch housing market. 


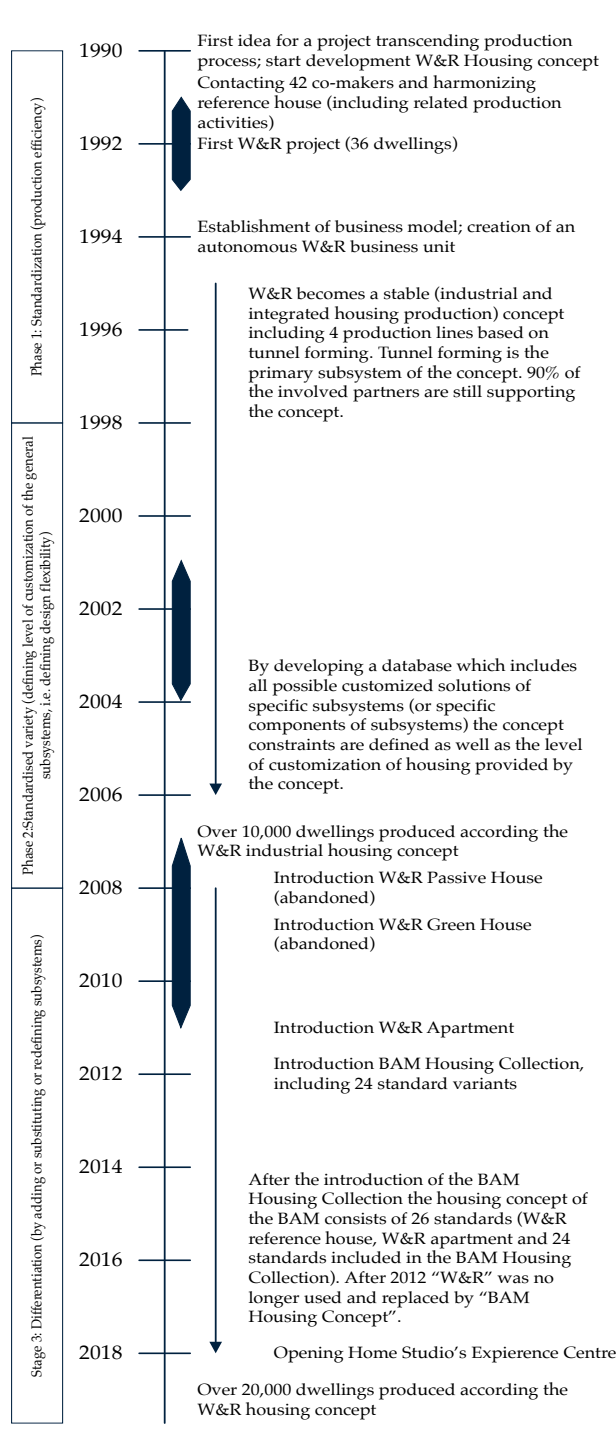

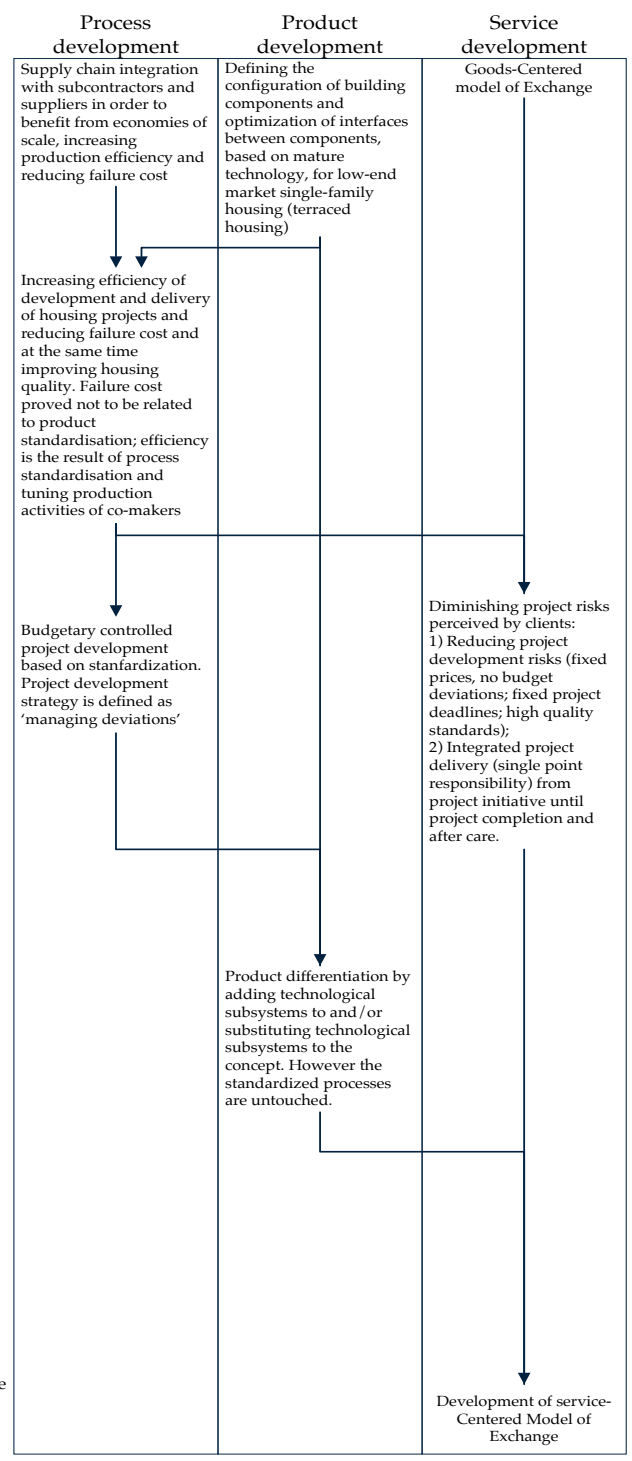

Figure 5.3: Development of the W\&R housing system. The arrows reflect the cyclical nature of construction (periods of economic downturn) 


\subsubsection{The First Stage: a Process of Product \& Process Standardization (1990-98)}

The first phase of the W\&R lifecycle encompassed the 'initial idea' of the system, the actual development of the system and initial market entry. The first phase anticipated and addressed the inefficiencies of housing delivery in the Netherlands. During the second half of the $20^{\text {th }}$ century, the building of large series of dozens, or even hundreds, of similar dwellings, could characterize residential construction projects for single-family dwellings in the Netherlands. As such, construction could be characterized as mass production. The traditional project organization, with temporary coalitions of specialists, could support individual team-based learning but did not necessarily lead to increased organizational performance. To increase efficiency and learning, BAM decided to move on from this traditional project-based approach to single-family housing production by developing and implementing $W \& R$, which is based on the following four organizational principles.

\section{A Project-Independent Coalition with Preferred Subcontractors and Suppliers}

The first organization principle that was implemented was a project-independent coalition with preferred subcontractors and suppliers for the construction of single-family dwellings. This resulted in a stable network of 42 partners. This coalition became one of the cornerstones of W\&R. Most of the original partners are still involved. BAM implemented long-term agreements with these partners, which resulted in (cost) efficient housebuilding and improved quality because of a substantial reduction of deficiencies, and reduced lead-time from start to finish of the project. Implementation of this organization principle made it possible to offer clients a fixed price and project planning and a guaranteed W\&R quality.

\section{A Standardized Development and Production Process}

BAM implemented a standardized production process by applying reinforced concrete tunnel formwork to construct the concrete bare structure of the dwellings on-site to which the prefabricated subsystems are connected. The production process was developed by BAM based on a reference house that represented the typical single-family dwellings in the Netherlands at that time. BAM, as the general contractor and system integrator, was and still is responsible for the on-site production of reinforced concrete tunnel formwork (forming concrete bays of separation walls and floors). All the other subsystems and related production activities are harmonized with the tunnel forming process. After production of the ground floor and first floor tunnels (and sometimes a second floor), the tunnel naves are closed with prefabricated façade elements. Next the roof, consisting of prefabricated gable-end elements and prefabricated roofing sheets, is put in place. As soon as the dwelling is wind- and waterproof, the finishing process is started, including bricklaying of the exterior walls, installation of the bathroom, kitchen and toilet, and additional finishing works such as plastering and tiling.

\section{A Stable Production Team in Terms of Composition and Members}

The production teams move from site to site, avoiding changes in the team composition 
and in individual team members. That is, the same team members work together and become fully attuned to one another. This result in increased productivity and a substantial reduction in costs linked to failures or mistakes.

Over time, five production lines have been established, each producing about 200 dwellings yearly. During periods of economic downturn, the fifth production line stays unused. To ensure long-term production continuity, BAM focuses on running these four and maximum five production lines, even when market demand allows higher production numbers.

\section{A Well-Considered Balance between Regionally and Centrally Directed Activities}

In order to be close to its potential clients, BAM's housing division operates from four regional independent offices spread across the Netherlands. These regional offices are responsible for the acquisition of new housing projects. The net benefits of a new housing project are allocated to the regional office concerned. Acquisition takes place by convincing potential professional clients of the competitive advantage of W\&R in terms of building quality and price, and the "single point of responsibility" approach that is followed by BAM. In this, BAM takes the overall responsibility for the whole realization process from design through to completion. Nevertheless, W\&R is centrally coordinated with respect to the procurement activities and the long-term agreements with building partners. The low price and short construction period that result from these applied organizational principles made $\mathrm{W} \& \mathrm{R}$ an attractive option for social and commercial property developers in the Netherlands.

\subsubsection{The Second Stage: Standardized Variety (1998-2008)}

The second phase of the W\&R lifecycle can be characterized as the creation of "standardized variety" by offering various standardized module-based options. Around the turn of the century, consumers in the Netherlands were becoming dissatisfied with standardized houses, even though they were of a reliable quality. In response, BAM sought ways to accommodate and increase the influence of clients on the design of future housing development projects, but without increasing the price too much and losing the advantages of serial production. To produce the required variety efficiently, the W\&R design was adapted to include modularity principles (e.g. Veenstra et al. (2006) and Hofman (2010)). Standardized variety was created by offering different module-based options for facades and roofs, and for internal finishes, although the core design of the reference building remained untouched. These efforts resulted in a database of optional components that could be mixed and matched in customizing the building envelope. This set of options was co-developed by BAM and its partners.

This database approach, with limited standard options, enabled the consortium to work with fixed prices for each option. This approach enabled an increase in flexibility and variety in product design while maintaining product quality and production speed. 
The third and current phase can be characterized by efforts to improve W\&R in terms of its energy performance and in a decision to widen the scope of target clients. The economic recession that began in 2008 led to a stagnating Dutch housing market and intensified competition therefore. To distinguish itself from its main competitors, BAM decided to renew and further improve W\&R by developing two sustainable variants: the W\&R Green House and the W\&R Passive House. During the same period, many competitors started to offer sustainable housing solutions and the competitive advantage of the W\&R Green House and the W\&R Passive House reduced. As a result, both variants were abandoned and instead several energy efficiency alternatives were developed. The alternatives can be selected as standardized options.

Parallel to the development of the W\&R Green House and the W\&R Passive House 2 other pathways were explored to develop additional variants. The first pathway led to the development of the W\&R apartment building of which the first project was completed in 2011. Subsequently, in 2012 the BAM Housing Collection was introduced. The housing collection encompasses three popular architectural styles, which were identified in close collaboration with AM. For each style eight housing types were developed.

Technology advancement and labour shortage also forces the BAM to reconsider the production standards of the W\&R housing system. Offsite production technologies are considered to remain attractive in the Dutch housing market. In particular, prefabrication of the load bearing structure and prefab masonry are considered. At the same time, design, engineering and offsite production processes are automated by full application of Building Information Modelling (BIM).

\subsubsection{The Fourth Stage: Service Orientation}

It is expected that, in the near future, property developers and occupants, will extend their requirements to include more service-based activities, and demand all-inclusive housing solutions. In particular, they will demand lifecycle-based services related to building services and maintenance. In addition, there is a growing demand from end-users for readyto-move-into housing. New development projects are in progress at BAM to extend their portfolio to respond to demands for these types of services. Subsequently, in September 2018 BAM opened the Home Studio's Experience Centre. In contrast to current practices in the Dutch housing market, BAM attempts to address a growing demand for ready-tomove-into housing by providing services to install the complete infill of the dwelling. Home Studio's provides a real-time experience, which helps occupants to select and buy the total infill of their house.

Above we described the successive development stages of the W\&R housing system in order to maintain its attractiveness over time. This analysis revealed a close match between 
the characteristics of $W \& R$ and the stage-gate adoption process applied in the housing sector. First of all, W\&R adheres to the preconditions set by housing clients when selecting house-builders. The local market orientation and market responsiveness are also considered distinctive characteristics of W\&R. Since the completion of the first project in 1992, W\&R gained a reputation of an efficient and affordable housing system. Based on a standardized housebuilding process and a stable project independent coalition of co-makers W\&R was able to develop and maintain a relative cost advantage in comparison with its competitors but could also often make the best value for money offer.

\subsection{Cross-case Analysis: Deriving Mechanisms of Continued Adoption}

In contrast to $W \& R$, many housing systems are not adopted beyond their demonstration phase. What differentiates the W\&R housing system from less-successful housing systems in terms of continuous adoption? First, we will present three housing systems, which were not adopted at a large scale beyond their demonstration phase. These housing systems include Concrete Slab House; Wood Pod House and Steel Frame. Second, we analysed several case specific, causal mechanisms that affect continuous adoption (Table 5.2). Subsequently, we deduce the case-specific findings to five generic continued adoption mechanisms.

\subsubsection{Concrete Slab House}

The Concrete Slab House system was developed by a Dutch architectural design firm and further developed in collaboration with a contractor and several suppliers who delivered the core technologies. Since independent suppliers are making the different modules, the Concrete Slab House can be considered as an 'open system'. Figure 5.4 shows the timeline with the key development steps and major (macro-economic) events hindering a continued adoption.

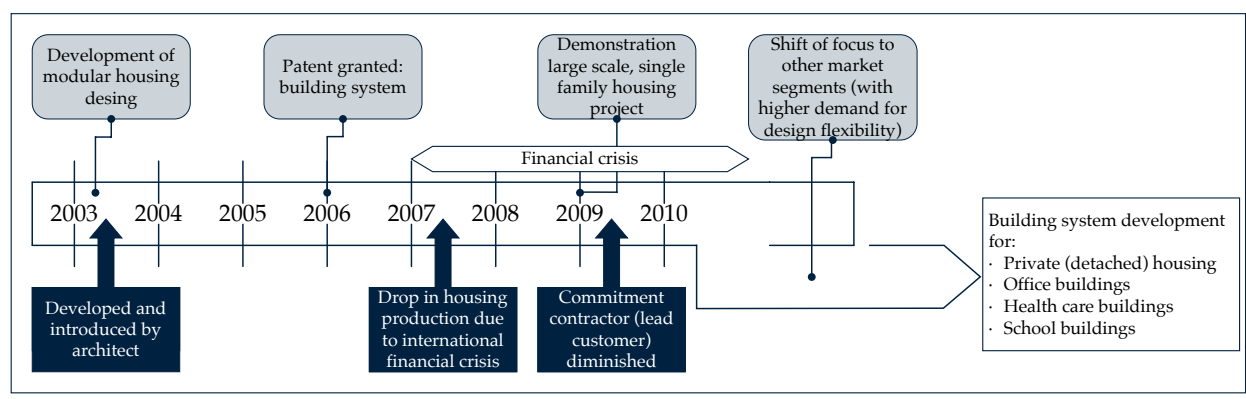

Figure 5.4: Timeline Concrete Slab House system with key development steps and major (macro-economic) events hindering a continued adoption 
The Concrete Slab House is based on a modular product architecture with standardized, plug-and-play interfaces connecting the specific modules. These industrial building modules include three subsystems: structural precast floor slabs, columns and exterior concrete sandwich wall elements. The functionalities of each subsystem are clearly defined and captured in standardized specifications and interfaces. Design and production flexibility is achieved by mixing and matching of the subsystems, and is based on standard steel couplings. As a result, and in contrast to traditional housing, building components can be fully disentangled. HVAC systems' pipes and ducts are not integrated in walls and floors but installed on top of the structural floor and are covered by a decoupled floor system in that the overall building can be adjusted in the future in accordance with changing needs.

The Concrete Slab House was adopted in 2009 in a project of a social housing corporation and 60 housing units were constructed. In addition, a couple of detached single-family dwellings were erected. Despite the advantages of the Concrete Slab House system (in 2010 the Concrete Slab House was awarded the sustainable building DUBO award), no further adoption by professional clients took place. Due to a lack of urgency and evidence, it appeared difficult to convince housing clients about the added value of the most important advantage of the Conrete Slab House, i.e. its flexibility to adapt the building against low costs. Initial building costs rather than time related life cycle considerations are still the dominant logic in awarding housing projects.

\subsubsection{Wood Pod House}

In contrast to the Concrete Slab House, which is based on 2D industrial building elements with fixed interfaces, the Wood Pod House has been based on industrial produced volumetric units. The basic structure of these volumetric units consists of a steel structure combined with timber frames. Although the ground floor initially also consisted of timber frames (to reduce weight) market demand required to redesign the floor by a steel frame concrete floor. The volumetric units were produced in a 'closed system' where the whole structure is prefabricated industrially in a single factory / production line. Besides the bare structure, also the infill modules, i.e. the bathroom and kitchen, are installed off-site. Standard sidings were used for the building exterior. A restriction related to volumetric units results from the maximum size, which can be transported by trucks as well as obstructions to reach the construction site like viaducts or narrow streets. The development of the Wood Pod House was the result of previous experiences with producing prefab holiday bungalows and subsequently the production of about 1,000 refugee dwellings in the period between 1999 and 2003 (during the Yugoslav wars 1991-2001). When the production of refugee housing stopped, the production facilities became obsolete and this stimulated the development of the Wood Pod House. Since 2004, about 500 single and multifamily houses were produced for the low-end market. This production ended in 2011 with the bankruptcy of the manufacturer. Figure 5.5 shows the timeline with the key development steps and major (macro-economic) events hindering a continued adoption. 


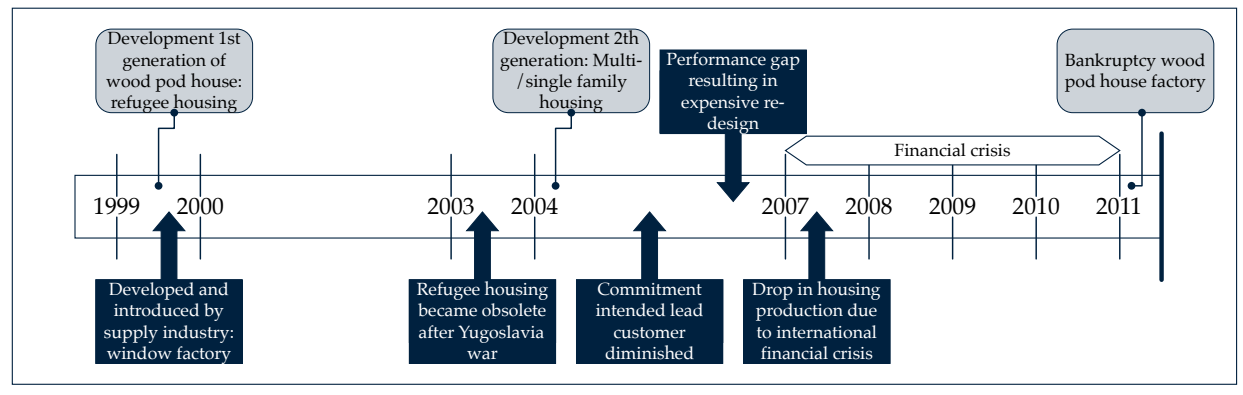

Figure 5.5: Timeline Wood Pod House with key development steps and major (macro-economic) events hindering a continued adoption

The Wood Pod House system was intitially developed for the production of housing solutions for a different market segment (holiday bugalows and refugee housing) and with deviating requirements. The volumetric units were responsible for high transportation costs ('we transport mostly air when moving volumetric units from factory to the building site').

To be able to compete in a cost-effective manner with traditional construction practices, the production line of the Wood Pod House system depended on large scale projects with a high level of replicability. It further turned out to be extremely difficult to anticipate fluctuations in demand. The economic crisis in particular resulted in a considerable decrease of large scale housing projects. In the same time, spatial planning policies in the Netherlands were changed towards a focus on the redevelopment of urban locations. This in contrast to urban expansion and house building on so-called green fields. As a result, the number of housing units per project deminished considerably which increased the cost per living unit for the Wood Pod House system. Thus, despite the maturity of the system and a proof of concept within a different market segment, it appeared not to be posible to realize a continued adoption for the Wood Pod House system.

\subsubsection{Steel Frame House}

Like the Concrete Slab House system, the Steel Frame House system is based upon an 'open system' approach where different modules are made by independent suppliers. A steel frame is used as bare structure supporting the wall and floor modules. The hybrid structural floor slaps are made of a concrete layer supported by steel ribs. The space between the steel ribs are used for the ducts and piping and are covered by a decoupled floor system which makes it possible to adjust the overall building in the (near) future. The building exterior walls consist of prefabricated sandwich wall elements while metal stud is used for the interior (separation) walls in order to create a flexible floor plan. Despite the leight weight of the building structure, laboratory tests showed that the building structure complies with building codes concerning fire protection, acoustics and structural integrity. 
The Steel Frame House (1994-1995) finds its roots in an university program to develop an 'innovative system of construction' which is based on the principles of Open Building (Bosma, 2000; Habraken and Teicher, 1972; Kendall, 2000). Today the Steel Frame House system has been abandoned, it was never adopted beyond the demonstration project supported by the Industrial, Flexible and Demontable demonstration programme (19992006) of the Ministry of Economic Affairs. The pilot consisted of 36 single family dwellings which were constructed in 2000. Nevertheless the Slimline floor system, an essential subsystem of the Steel Frame House, is still available in the market and because of the successfull application of this floor system its reputation and uptake improves. Figure 5.6 shows the timeline with the key development steps and the major (macro-economic) events hindering a continued adoption.

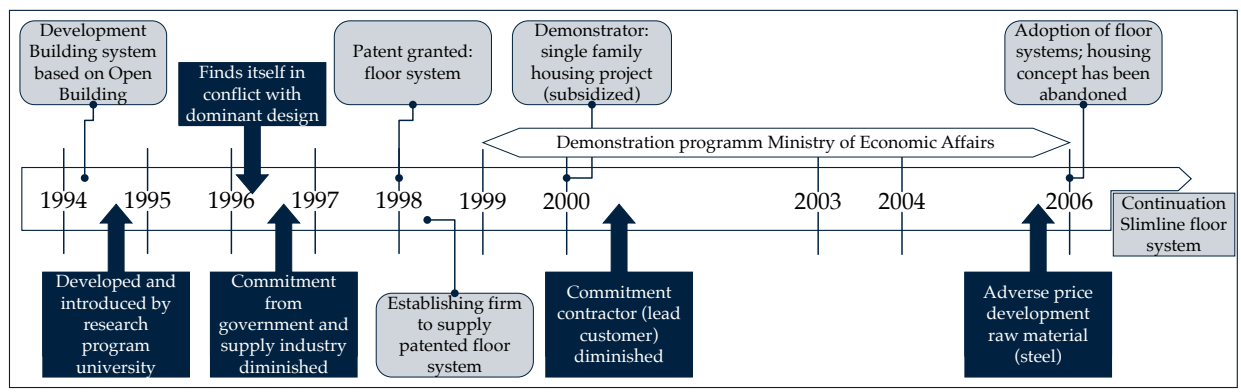

Figure 5.6: Steel Frame House with key development steps and major (macro-economic) events hindering a continued adoption

The relative advantage of the Steel Frame House comprises the flexibility and functionality of the dwellings which can be adjusted to accommodate future needs. The Steel Frame House system and in particular the innovative floor system (Slimline floor) earned recognition in the form of subsidies, an innovation award and a patent which was granted for the Slimline floor system. However, like the Concrete Slab House system, it appeared difficult to convince housing clients about the added value to pay extra for the created flexibility to easily adapt the building against low costs in the (near) future. Another reason for the resistance to adopt the Steel Frame House system in The Netherlands has been the difference between the traditional massive concrete floor of $800 \mathrm{~kg} / \mathrm{m} 2$ that is normally used in dwellings versus the choice for a hollow core floor system in the Steel Frame system. Although laboratoy tests revealed that the acoustic performance of both systems was comparable, the general acceptance of the new developed hollow core floor system caused resistance and skepticism. Finally, also the development of raw material prices had a negative effect on the continued adoption of the Steel Frame House system. Since its market introduction in the mid 1990s the price of construction steel increased rapidly and as a result the Steel Frame House system became too expensive in comparison with traditional solutions. 
Despite its perceived relative advantages with respect to industrialization, flexibility and sustainability, one may argument that the Steel Frame House system was launched in a too early time and that it also deviated too radically from traditional construction practices that were used in those times. This explaines why a continued adoption appeared to be difficult for this system.

\subsection{Deriving Mechanisms of Continued Adoption}

The generic continuous adoption mechanisms were developed iteratively, by comparing the mechanisms found across the four case studies, and re-examining each individual case. From this five mechanisms were identified which play a determining role in the continued adoption of W\&R: the housing system supplier needs to have a regional presence; needs to deliver operational excellence; comply with technology standards in the housing sector; needs to provide competitive added value, and; needs to be able to comply with changing market needs. Each mechanism ties together several adoption determinants as addressed in Table 5.2. 


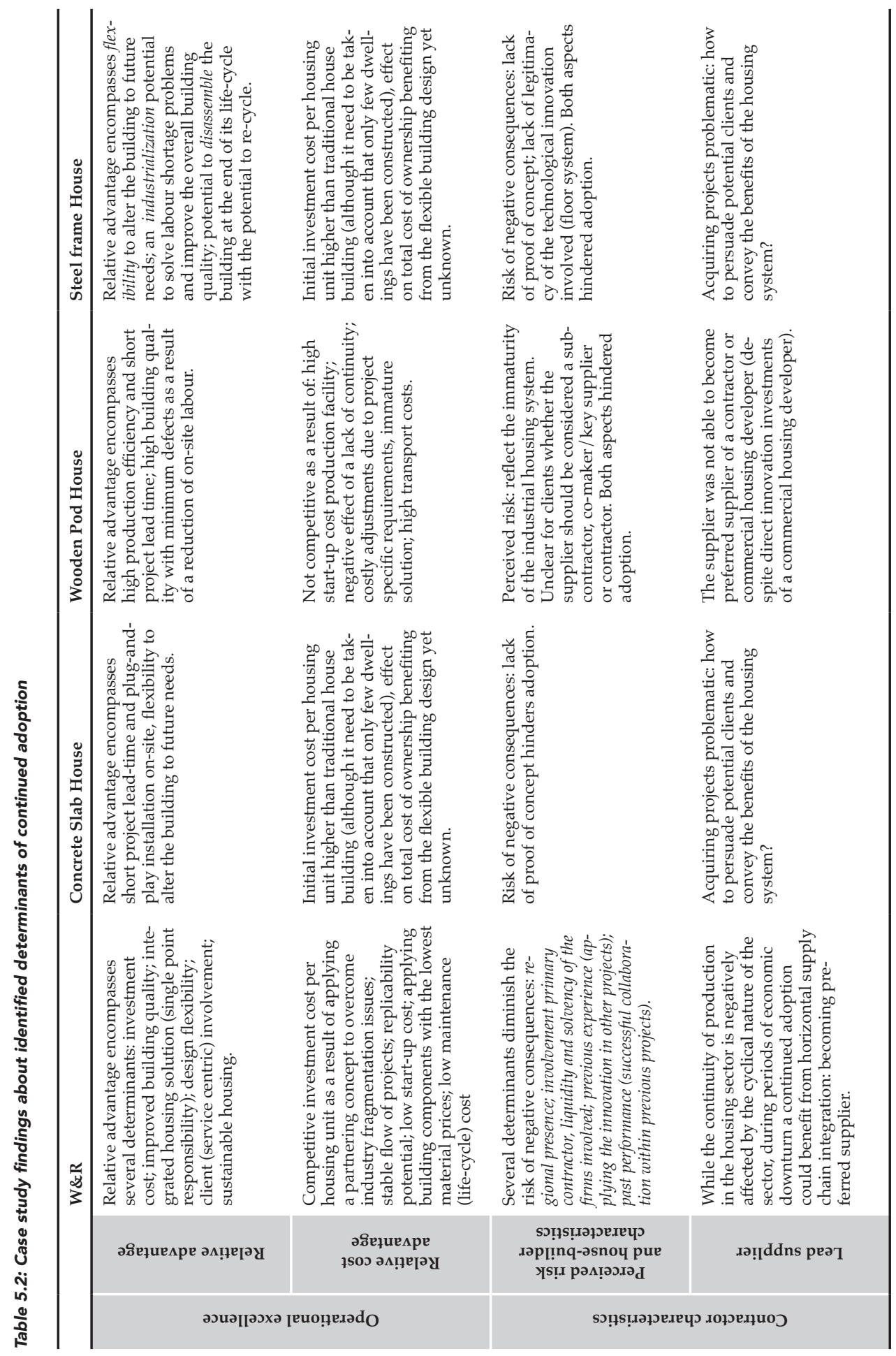




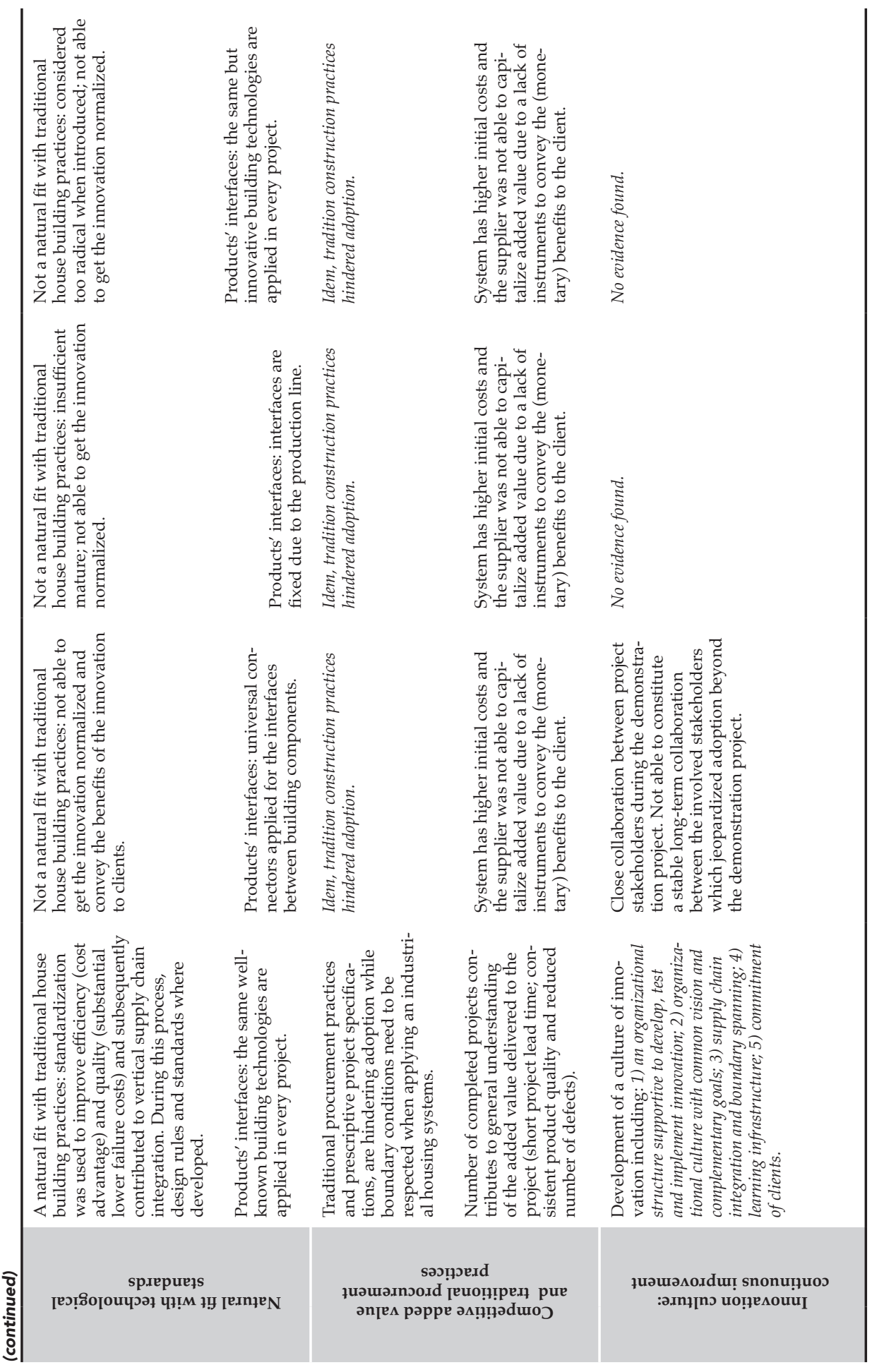




\subsubsection{Contractor Characteristics}

In the first phase of contractor selection, the building competence of the contractor and their financial solvency and liquidity situation are important criteria. For innovators developing housing systems it is important to closely work together with their main suppliers (as co-developer or lead customer) while property developers only tend to invite house builders to submit a tender for their projects.

Besides that, property developers, at least in the Netherlands, also consider the regional presence of the contractor, the availability of a single point of responsibility for the project, and the proposed housing system to have a proven maturity as important selection criteria. Within the W\&R case, the initial maturity of the housing system was demonstrated by the building of a reference house that reflected the then current best features of single-family dwellings constructed for social housing in the Netherlands. As explained earlier in this paper, BAM operates from four regional commercial business units that are responsible for the acquisition of new housing projects. Acquisition takes place by convincing potential clients of the relative competitive advantage of the W\&R system in terms of building quality and price, and highlighting the "single point of responsibility" approach that is followed by BAM. In this, BAM takes overall responsibility for the whole realization process from design to completion, thus meeting several of the selection criteria.

In contrast, the less successful housing systems did not meet one or several of these conditional adoption determinants. First, the demonstration projects completed did not provide proof of concept about the key relative advantages of the housing system. The demonstrators did not provide evidence about their capability to adapt the housing system to changing needs and neither they showed how the client could benefit from industrial building practices. Second, the suppliers of the less successful housing systems lacked some of the supplier characteristics of which regional presence is considered one of the most important.

Furthermore, while the continuity of production in the housing sector is hard to achieve and negatively affected by the cyclical nature of production, continued adoption could benefit from a proper project acquisition strategy. From the cross case analyses it was derived that becoming a preferred supplier of at least one client could sustain continued adoption.

Taken together, adopters take into account several supplier characteristics in order to manage the risks associated with the adoption of industrial housing systems. These supplier characteristics include: Regional presence; Involvement of the primary contractor (integrated project delivery); Liquidity and solvency of the firms involved; Previous experience (applying the innovation in other projects), and; Past performance (successful collaboration within previous projects). 


\subsubsection{Operational Excellence}

Treacy and Wiersema (1993; 1995) outline potential business strategies that companies may successfully follow. They made a distinction between companies who excel in operations, in product leadership or who follow a customer intimacy strategy. Companies that pursue the Product leadership route offer a continuous stream of state-of-the-art products and services. The strategic Operational Excellence approach to the production and delivery of products and services aims to lead in terms of price and hassle-free service by making their operations lean and efficient. Finally, the Customer Intimacy strategy is characterized by companies who continually tailor and shape products and services to fit one or a few customer niches. In order to be competitive, an enterprise needs to be at least competent in all three disciplines, but to be a market leader it is important to excel in just one discipline. Treacy and Wiersema further argue that an enterprise cannot excel in all three disciplines because the basic enterprise culture, structures, people, facilities, processes and business models that lead to excellence in any one discipline are incompatible with achieving excellence in the others.

By implementing these organizational principles, BAM was able to realize and maintain a cost leadership position in the housing industry in the Netherlands. Since price is an important criterion in the second phase of the stage-gate selection process, BAM's cost leadership position is often critical.

In contrast, the less successful housing systems were not able to master one of Treacy and Wiersema's business strategies and in particular turned out not to be competitive with respect to (initial building) cost. The less successful systems were hindered by several economic inertia including high investment cost in industrialised production facilities, high transport cost and, increasing raw material prices. In addition, the less successful industrial housing systems were not able to create continuity and scale in housing production. W\&R benefitted from its close collaboration with AMPD, a project development firm, being part of the Royal BAM Group. By consolidating a continued stream of housing projects, BAM was able to keep the production cost per housing unit low.

\subsubsection{Natural fit with existing technology standards in the housing industry}

Nelson and Winter (1977) defined a technological regime as 'the shared cognitive believe among technicians about feasible technologies' (p57). The empirical literature on technological regimes argues that firms within an industry behave in correlated ways because they share sources of information and technology and perceive similar opportunities for innovation. Firms in the same industry are also likely to have similar users that provide ideas and demand for innovation (Leiponen and Drejer, 2007). In the nineties the definition of a technological regime was refined by Van den Ende and Kemp (1999) as: 'the complex of scientific knowledge, engineering practices, production process technologies, product characteristics, user practise, skills and procedures, and institutions and infrastructures that make up the totality of a technology' (p835). 
This extension was made because of the complexity of interactions between different actors such as users, policy makers, societal groups, suppliers and scientists in a technological regime. With respect to the potential adoption of new technologies, Rip and Kemp (1998) pointed earlier to the difficulty to replace existing adopted technologies. Implementation, adoption, use, and domestication of technology create and maintain social and technical linkages that are hard to undo. This makes it very difficult for new entrants to replace a dominant technological standard or to change current construction practices and realize a continued adoption beyond the demonstration phase of a specific project.

The W\&R housing system applies mature construction technologies and BAM was able to innovate the construction process based on production line principles by working closely together with co-makers they already knew from previous projects. It turned out that the W\&R housing system did not radically diverted from the traditional, technological regime of housing delivery in the Netherlands. In contrast, the less successful systems conflicted with the dominant technological standards in the housing sector. For instance, the Steel Frame House encompasses an innovative floor system, which separates the structural floor from the infill floor. As a result, the ducts and pipes included in the hollow core floor system can be adjusted during the building's life cycle. However, traditionally massive concrete floors are used in The Netherlands for decades because of their building-acoustic and fire-resistant properties. Despite laboratory tests proofing that the hollow core floor system meets the same performance criteria, the hollow core floor system was and still is questioned by the industry.

\subsubsection{Competitive added value}

In the last stage of the selection process, property developers compare the remaining options in terms of their expected quality and any additional functionalities that are offered relative to the bid price. Aspects such as variety, flexibility, sustainability of materials, energy use and maintenance costs during the expected lifetime of the housing are potential additional criteria that may be used to compare the competitive biddings. Above all, as was learned from the W\&R case study, upfront guarantees about investment cost and short project lead-time are considered to provide decisive added value to clients since it reduces potential project risks. Next, in response to customer expectations, BAM has created, in the last decade, a variety of standardized (service) modules or options that can be selected. This has made it possible to increase the influence of clients on the design of housing solutions, while still maintaining an attractive price offering. In addition, a major effort was made to improve the W\&R housing system in terms of energy performance. To further prolong its competitive position, the company is working now on developing additional customer centric services.

Since the Concrete Slab House system, the Wood Pod House system and the Steel Frame House system did not survive the competition in the market, it will be difficult if not impossible to determine the competitive added value of these three specific housing systems. 


\subsubsection{Ability of the builder to keep pace to changing market requirements}

Over time, several adjustments were introduced in the W\&R housing system because of changing market requirements. These changing market requirements included the improvement of the sustainability of the housing system and providing additional services. In order to address changing market requirements, subsequently develop, and implement innovative solutions, BAM had to develop certain organizational capabilities. An extensive body of literature is available about the management of innovation by organizations in the construction sector (e.g. Blayse and Manley (2004); Bossink (2004); Gambatese and Hallowell (2011a, 2011b); Gann and Salter (2000); Reichstein et al. (2005, 2008)). From this body of literature, we were able to deduce five organizational design principles that may be considered important to support a continued adoption:

1. The involvement of a principal contractor as system integrator is key to innovation, managing 'ideas into good currency' (Winch, 1998). This requires the development and alignment of competences in the regulatory framework, capabilities to incorporate client needs into the housing system, and skills to integrate technologies from the co-makers into the system as a whole. The case study has clarified the role of BAM as a system integrator. Innovations are developed, tested and implemented in close collaboration with a project-independent coalition of preferred subcontractors and suppliers.

2. An open, accepting and positive organizational climate and culture, is found to be conductive to innovation (Blayse and Manley, 2004; Gambatese and Hallowell, 2011a). In the W\&R case study, the 'compatibility between organizations' was particularly mentioned as a characteristic aspect of innovation management process for the W\&R housing system. Firms appeared to share a common vision, had complementary goals, and were willing to share resources, knowledge, technical capacity and competencies to develop and implement new developments.

3. Supply chain integration and boundary spanning initiatives to co-innovate across the boundaries within and across organizations contribute to keep pace with changing market requirements and to maintain a competitive advantage over alternatives (Bossink, 2004; Gann and Salter, 2000). With respect to the W\&R housing system, these boundary spanning initiatives not only resulted into a stable network of collaborating partners and production teams, but also into close network ties with clients and architects.

4. Close network ties facilitate the required sharing of knowledge and information to develop and implement innovations to address changing market requirements (Blayse and Manley, 2004; Gann and Salter, 2000; Winch, 1998). In the W\&R case, the intense project-independent cooperation between co-makers created an innovation infrastructure that contributed to the development of learning and feedback loops. A stable project portfolio contributes to the development of certain organizational resources, in particular technological and integrative competences. These competences are required to develop and implement innovation. 
5. A stable project portfolio will also reduce the risk of not recovering the initial development cost of innovations (Blayse and Manley, 2004; Gambatese and Hallowell, 2011a; Gann and Salter, 2000; Winch, 1998). In the past decades, the W\&R housing system organization has built up a reputation and past performance to acquire new projects.

\subsection{Discussion and conclusion}

This multiple case study is among the first to study the mechanisms which affect a continued adoption of industrial housing systems across housing projects in the Netherlands. To derive at these mechanisms we compared a rare example of a successful industrial housing system with three housing systems which did not experience a continued adoption. Our multiple case study was guided by two research questions: 1) what differentiates the W\&R housing system from housing systems, which did not experience a continued adoption and, 2) which mechanisms contribute to a continued adoption over time and across housing projects?

Regarding the first research question, a key feature which differentiates $W \& R$ from the three other cases is its coherent organization and management of the successive stages in a housebuilding process. To really benefit from the potential that industrial housing systems have to offer, a well-coordinated planning and control is needed that integrates the interrelated processes of design, manufacturing, (on-site) assembly and other related processes such as procurement, sales and marketing (Kamar and Hamid, 2011; Lessing et al., 2015; Lindgren and Emmitt, 2017). The multiple case study showed that BAM, if compared with its less successful competitors, excels in the way how it organizes and manages the housebuilding value chain. Since the market introduction of the W\&R system, BAM has been able to integrate both the up- and downstream value chain. Downstream they built a stable network of partners with whom they collaboratively construct houses in large scale housing projects. Upstream BAM closely collaborate with architects and designers to offer design variety to housing clients. Moreover, in many projects they are involved as a consultant to support property development in order to maximise the potential of the W\&R housing system, in particularly in projects developed by AM Property Development which is a subsidiary of the BAM holding.

The three less successful case studies showed that poorly controlled housing systems in terms of design, (pre-)fabrication and site assembly processes increase inefficiency and cost due to non-value-adding activities which in turn harm the potential benefits to be gained from industrialisation. The less successful housing systems in particular showcased partial and superficial supply chain integration.. Thus, supply chain integration is elementary to maximise the potential of industrial housing systems and as such key to continued adoption. Controlling the successive stages of the housebuilding process pro- 
vides major possibilities for continued adoption, as it enables more autonomous development to improve efficiency and competitiveness in line with changing market conditions (Kamar and Hamid, 2011; Lindgren and Emmitt, 2017).

This study has revealed the importance of maintaining a cost leadership position in the market and to keep pace with changing market requirements by further improving and developing the existing housing system. The $W \& R$ housing system has evolved from a focus that was primarily on standardization, to standardized variety, to differentiation, and now towards the inclusion of a service orientation. Regarding the second research question, we were able to deduce that the continued adoption of an industrial housing system in The Netherlands depends on: A regional presence of the system provider; the provision of excellent low-cost housing solutions; A natural fit with existing technology standards in the housing sector; The offering of competitive additional functionalities and quality in addition to the low cost focus and; The flexibility of the organization to keep pace with changing market and society needs and requirements such as with respect to circularity, energy efficiency and low maintenance and life cycle costs.

Finally, we identified several limitations and directions for future research. Although the findings are based on an extensive longitudinal case study and three complementary case studies, to generalize the findings, additional empirical data is needed. To this end future research may focus on testing in a large-scale study the identified mechanisms that affect a continued adoption of industrial housing systems. A second limitation is that one market, namely large scale housing projects in the affordable (low-cost) housing market in The Netherlands has been studied. Future studies could extend the research to other market segments and to housing projects in other countries and use cross-national data to account for differences in institutional structure. Third, this article studied the role of professional housing clients in the procurement of housing systems in particular the low-end market. Future research could extend the study about the role that clients play in the process of a continued adoption of new developed building systems. This could help building developers to overcome the impediments they face in dealing with clients as a buyer of building solutions. Addressing the future research opportunities described above would be an important contribution, from an academic, managerial and a policy point of view. This research has contributed by offering a useful foundation for expanding the investigation about continued adoption in large-scale studies and to other sectors. This will broaden our knowledge about the possibilities to realize continued adoption in the construction industry. 



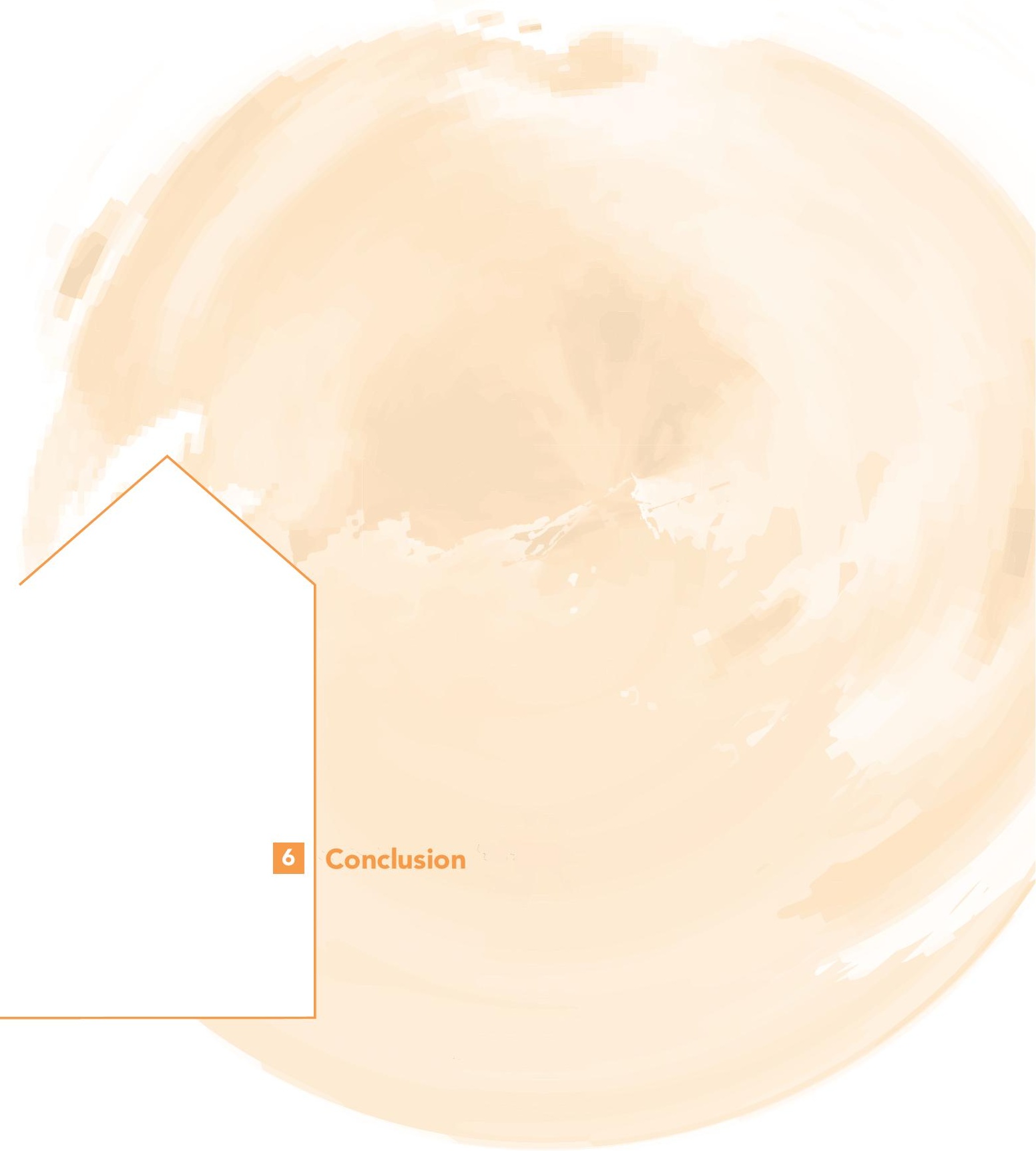




\section{Conclusion}

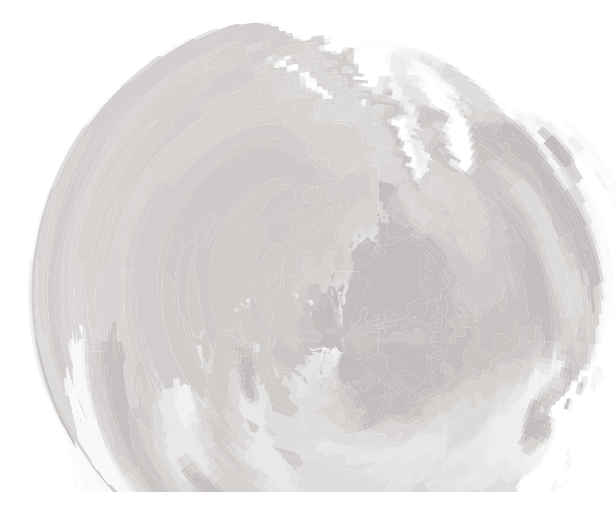

This final chapter summarizes the main contributions and implications of this $\mathrm{PhD}$ research. The first section provides a brief overview of the research questions and methods that were used in Chapters 2-5. Subsequently, in the second section, a summary is provided of the main scientific contributions. In the third and fourth sections of this chapter, the implications for future research and practice are discussed. The chapter ends with a reflection on the research presented in this thesis. 


\subsection{Research questions and methods}

This section provides an overview of the methods that were used toaddress the seven research sub-questions addressed in the four studies presented in the previous chapters (summarized in Table 6.1). Given the different types of research questions, various methods were used.

Table 6.1: Research questions and methods in the four studies

\begin{tabular}{|c|c|c|}
\hline Study & Research questions addressed & Method \\
\hline $\begin{array}{l}\text { Study I } \\
\text { (Chapter 2) }\end{array}$ & $\begin{array}{l}\text { 1. What are the key theoretical cornerstones of } \\
\text { innovation adoption research? } \\
\text { 2. What are the current research trends within the field } \\
\text { of innovation adoption? }\end{array}$ & $\begin{array}{l}\text { Bibliometric review of innovation } \\
\text { adoption literature }\end{array}$ \\
\hline $\begin{array}{l}\text { Study II } \\
\text { (Chapter 3) }\end{array}$ & $\begin{array}{l}\text { 3. Which determinants affect the adoption of } \\
\text { innovation in the context of housing projects? }\end{array}$ & $\begin{array}{l}\text { Systematic narrative review and } \\
\text { synthesis of innovation literature on } \\
\text { housing }\end{array}$ \\
\hline $\begin{array}{l}\text { Study III } \\
\text { (Chapter 4) }\end{array}$ & $\begin{array}{l}\text { 4. Which determining factors and causal mechanisms } \\
\text { influence the adoption of modular innovations in the } \\
\text { housing sector? } \\
\text { 5. To what extent can the theory on modularity help to } \\
\text { explain the adoption of modular innovation in the } \\
\text { housing sector? }\end{array}$ & $\begin{array}{l}\text { Multiple-case study of modular } \\
\text { innovation in housing }\end{array}$ \\
\hline $\begin{array}{l}\text { Study IV } \\
\text { (Chapter 5) }\end{array}$ & $\begin{array}{l}\text { 6. What differentiates the W\&R housing system from } \\
\text { housing systems, which did not experience a } \\
\text { continued adoption? } \\
\text { 7. Which mechanisms contribute to a continued } \\
\text { adoption over time and across housing projects? }\end{array}$ & $\begin{array}{l}\text { Longitudinal, in-depth multiple-case } \\
\text { study in housing }\end{array}$ \\
\hline
\end{tabular}

Literature reviews were conducted to answer the research questions posed in Studies I and II. In the bibliometric study for Study I, thematic similarities across scientific articles on innovation adoption were identified through the use of two bibliometric analysis techniques: bibliographic coupling and co-citation analysis. With the help of these analysis techniques, 1,260 scientific articles on innovation adoption were reviewed in-depth.

For the literature review in Study II, a search in Clarivate Analytics' Web-of Science, Elsevier's Scopus and ARCOM, followed by 'snowballing' as a backward search technique, revealed 94 scientific articles on innovation adoption in the housing sector. These articles were used to conduct a systematic narrative literature review on innovation adoption in the housing sector.

To answer the research questions of Study III, a multiple-case study was conducted investigating three different modular innovations within the Dutch housing industry. For each case, besides a study of relevant documents, in-depth interviews were conducted with key stakeholders involved with the respective modules. These stakeholders held important managerial positions and were involved in the decision-making process over adoption. Data analysis consisted of examining, categorizing, tabulating, testing, or otherwise recombining, evidence to draw empirically based conclusions. To validate the data collected in the individual interviews and the results of the data analysis, workshop sessions were organized for each of the three case studies. 
Once the data were collected and structured, a cross-case analysis took place to arrive at generic conclusions with respect to adoption variables. The cross-case analysis was followed by an analysis of possible relationships between the identified adoption variables. Based on this analysis, four causal mechanisms were deduced that determined the adoption of the modular components in the three case studies.

To answer the research questions of Study IV, a multiple-case study, encompassing four industrial housing systems, was conducted. In all four systems, prefabricated building components produced off site were used. Similar to Study III, the research process consisted of data collection through the study of relevant documents and in-depth interviews, data analysis and validation of each case, followed by a cross-case analysis. Finally, a workshop, annexed to a symposium, was organized in which the results of Study IV were presented. Over 60 people, all active in the housing development market and including most of the interviewees, attended. The debates were taped and subsequently used in carrying out a content analysis. 


\subsection{Summary of the main scientific contributions}

This section summarizes the main contributions of each of the conducted studies towards achieving the overall aim of this $\mathrm{PhD}$ research. This section concludes with a discussion of the overall contribution of the thesis.

\subsubsection{Main scientific contributions of the four studies}

A concise summary of the main scientific contributions of the four studies of this thesis are presented in Table 6.2.

Table 6.2: Summary of the main scientific contributions

\begin{tabular}{|c|c|c|}
\hline Study & Research questions addressed & Scientific contributions \\
\hline Study I & $\begin{array}{l}\text { 1. What are the key theoretical cornerstones } \\
\text { of innovation adoption research? } \\
\text { 2. What are the current research trends } \\
\text { within the field of innovation adoption? }\end{array}$ & $\begin{array}{l}\text { - Innovation adoption is built on four theoretical } \\
\text { cornerstones } \\
\text { - Five clusters of thematic-related publications } \\
\text { identified } \\
\text { - A coherent framework to assess the } \\
\text { relevance of innovation adoption research and } \\
\text { to provide guidelines for scholars in positioning } \\
\text { their future research efforts }\end{array}$ \\
\hline Study II & $\begin{array}{l}\text { 3. Which determinants affect the adoption } \\
\text { of innovation in the context of housing } \\
\text { projects? }\end{array}$ & $\begin{array}{l}\text { - A taxonomy of housing innovation } \\
\text { - A coherent framework including the factors } \\
\text { which hinder or stimulate innovation adoption } \\
\text { in housing projects } \\
\text { - } 21 \text { causal mechanisms were identified that affect } \\
\text { the adoption of innovation in housing projects }\end{array}$ \\
\hline Study III & $\begin{array}{l}\text { 4. What determining factors and causal } \\
\text { mechanisms influence the adoption of } \\
\text { modular innovations in the housing } \\
\text { sector? } \\
\text { 5. To what extent can the theory on } \\
\text { modularity help to explain the adoption } \\
\text { of modular innovation in the housing } \\
\text { sector? }\end{array}$ & $\begin{array}{l}\text { Ten interrelated variables that influence the } \\
\text { adoption of modular innovations in housing } \\
\text { projects } \\
\text { - The deduction of four mechanisms that influ- } \\
\text { ence the process of innovation adoption } \\
\text { - Modular innovation adoption depends on the } \\
\text { coherence between three dimensions of mod- } \\
\text { ularity }\end{array}$ \\
\hline Study IV & $\begin{array}{l}\text { 6. What differentiates the W\&R housing } \\
\text { system from housing systems, which did } \\
\text { not experience a continued adoption? } \\
\text { 7. Which mechanisms contribute to a } \\
\text { continued adoption over time and across } \\
\text { housing projects? }\end{array}$ & $\begin{array}{l}\text { - Housing systems mature through subsequent } \\
\text { stages of development } \\
\text { - Adoption depends on a stage-gate adoption } \\
\text { decision-making process } \\
\text { - Five primary conditions play a determining role } \\
\text { in the eventual continued adoption }\end{array}$ \\
\hline
\end{tabular}


Study I: A bibliometric review of innovation adoption - The findings of Study I complement existing reviews on innovation adoption in various ways. First, based on the conducted co-citation analysis, it became possible to illustrate that innovation adoption research is built on four theoretical cornerstones. These are: a) institutional theory and the legitimization of innovative behaviour; b) theory of reasoned action and the Technology Acceptance Model; c) the determinants of innovation adoption through an economic perspective; and d) diffusion theory.

Second, the bibliographic coupling technique revealed five clusters of thematic publications or "research trends": 1) drivers and impediments of information technology adoption; 2) the adoption of technology standards; 3 ) organizational rationales associated with innovation adoption; 4) modelling the diffusion process; and 5) adoption of agricultural innovations. Third, a coherent framework was constructed to assess the relevance of innovation adoption research by integrating the theoretical cornerstones and the current research trends. Fourth, as a key output, Study I also contributed by indicating several future research orientations.

Study II: a literature review on innovation adoption in the housing sector - An important contribution of the systematic narrative literature review in Study II is the structured synthesis of a fragmented body of literature on the adoption of innovation in housing projects. Study II contributes in three ways. First, a taxonomy of housing innovation has been developed which characterizes the innovations adopted in housing. Second, it presents the factors which stimulate or hinder the adoption of innovation in housing projects and structures these in a coherent framework. Third, it identified 21 causal mechanisms that affect the adoption of innovation in housing projects.

Study III: the adoption of modular innovations in housing projects - Study III is among the first to study the mechanisms that affect the adoption of innovative, modular housing products. Study III contributes in two ways. First, it has empirically revealed 10 interrelated variables that influence modular product innovation in housing projects. As a second contribution, Study III provides empirical evidence supporting Fine's modularity framework (Ellram et al., 2007; Fine et al., 2005) and the effect of modularity on adoption. Applying Fine's three-dimensional modularity concept enabled four mechanisms to be deduced that influence the process of innovation adoption. These mechanisms support previous research findings that suggest that, when products become modular, the production process and the supply chain need to move in a similar direction. Moreover, the four identified adoption mechanisms led to the hypothesis that the adoption of modular housing products depends on the coherence between the three dimensions of modularity.

Study IV: the continued adoption of building systems in housing projects - Study IV contributes in four ways to theory development on the continued adoption of systemic innovation in the housing sector. First, it illustrates how the W\&R housing system, as an example of a housing system that has been continually adopted, matured through four 
stages of development. Second, it revealed that adoption depends on a stage-gate adoption decision-making process linked to the project-based nature of housing construction. Third, based on a cross-case analysis of the W\&R system and three unsuccessful housing systems, Study IV highlights the primary conditions that need to be met to sustain ongoing adoption across projects. As a final contribution, Study IV revealed that the continued adoption of a mature housing system depends on five determinant factors. These are: (1) the regional presence of the housing system provider; (2) the provision of excellent lowcost housing solutions; (3) a natural fit with existing technology standards in the housing sector; (4) the offering of competitive additional functionalities and quality in addition to a low-cost focus; and (5) the flexibility to adapt the housing system to changing market requirements and societal needs, such as energy efficiency, low maintenance and low lifecycle costs.

\subsubsection{Overall scientific contribution}

The aim of this thesis has been to discover the variables and mechanisms that affect the adoption of innovation in the housing sector. By conducting two extensive complementary literature reviews, it became possible to develop a coherent framework of innovation adoption. This framework includes four categories of determinants involving a total of 21 factors. This coherent framework was then further explored during two extensive multiple-case studies. Within the first multiple-case study, involving several iterations re-examining the case data and repeating the cross-case analysis, the key variables affecting the adoption of modular innovations were studied. This exploration of the key adoption variables was followed by an analysis of possible relationships among the identified adoption variables. This analysis led to the deduction of four causal mechanisms that had determined the adoption of the analysed modular innovations. As such, it was shown that it is important to assess the internal causality among variables to explain the adoption of innovation (Eden et al., 1992; Sexton et al., 2006; Swan and Newell, 1994; Tan et al., 2017). This approach led to the important finding that, to successfully develop modular products, the production process and the supply chain also need to be modularized.

The second multiple-case study explored further to identify those mechanisms that determine whether an innovative industrialized housing systems enjoys continued adoption or disappears after an initial trial. It was found that, in addition to the adoption variables included in the innovation adoption framework, industrial housing systems have to meet five primary conditions. In addition to a regional presence, the provision of excellent cost-efficient housing solutions and a natural fit with the prevailing technology standards in the housing sector, industrial housing systems must also possess competitive functionalities and quality, and be adaptable to keep pace with changing market and societal needs. An additional competitive value can be linked to an advanced service orientation. Alongside a low-cost and best-value-for-money orientation, offering a service orientation has become an increasingly important competitive edge for innovation and for prolonging the adoption of an existing housing system. 


\subsection{Managerial and policy implications}

In this section, we identify the main managerial and policy implications that follow from the research reported in the previous chapters. Highlighting these implications has the purpose of stimulating the uptake of relevant innovations to address some of the most persistent challenges in the housing sector such as the increasing demand for affordable housing, labour shortages, a significant environmental impact and fast-changing market needs. Ideally, housing innovations, and in particular the type of innovations studied in this $\mathrm{PhD}$ research project, will not only contribute to shorter building times, lower failure costs and a higher build quality, but also result in more sustainable and circular building concepts. A concise summary of the main managerial and policy implications of the four studies of this thesis is provided in Table 6.3 and discussed in more detail below.

Table 6.3: Summary of the main managerial and policy implications

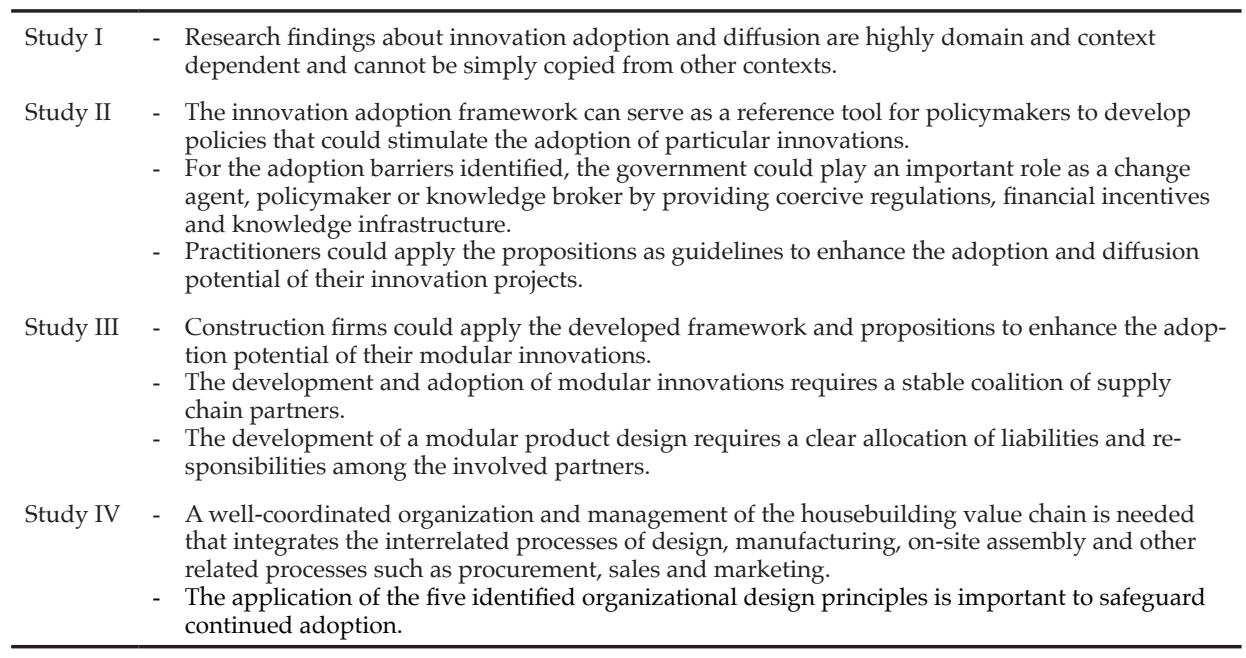

One of the important findings of the bibliometric review conducted in Study I concerns the fact that research outcomes related to innovation adoption are to a great extent dependent on the specific domain in which they have been conducted. As such, managers and policymakers cannot simply copy the findings directly from other contexts. That is, the adoption of innovations in the housing sector depends on mechanisms that are specific to the housing sector. This finding was an important reason for the extensive literature review in Study II on innovation specifically in the housing sector.

The literature review in Study II made it possible to identify policy as well as managerial suggestions for innovation practice. The innovation adoption framework that has been developed in Study II can serve as a reference tool to inform policymakers when developing policies to stimulate the adoption of particular innovations. For some of the key adoption barriers identified like perceived risk, inflexible financial arrangements and knowledge unavailability, the government could play an important role as change agent, policymaker and knowledge broker by providing coercive regula- 
tions, financial incentives and knowledge infrastructure. As an example, the European Parliament introduced an Energy Performance of Buildings Directive, Directive 2010/31 / EU, which stimulates the adoption of energy efficiency technologies. For practitioners, the findings of Study II show which mechanisms affect the adoption of a particular technological innovation in house building. The comprehensive innovation adoption framework developed may be helpful for innovation managers in taking into account the full range of determinants affecting the potential adoption of an innovation. In particular, the 21 developed propositions could be helpful in identifying critical prerequisites for successful adoption.

The multiple-case study in Study III is among the first to study the mechanisms that affect the adoption of modular innovations in housing projects. Construction firms could apply the developed framework and propositions to critically analyse modular innovations they are working on with the aim of enhancing their adoption potential. An important implication of Study III is that the development and successful adoption of a modular innovation requires a stable coalition of supply chain partners with clear arrangements between the involved partners about all the liabilities and responsibilities. To meet these requirements, both the process and the supply chain need to be developed in a modular way to align with product modularity.

Study IV revealed that, to safeguard continued adoption of a housing system, managers need to pay attention to implementing five organizational design principles. These are:

- The involvement of a principal contractor acting as systems integrator;

- Project-independent cooperation between co-makers to create an innovation infrastructure that contributes to the development of learning and feedback loops;

- Supply chain integration and boundary spanning initiatives to co-innovate across the boundaries within and across organizations to keep pace with changing market requirements and to maintain a competitive advantage over alternative systems;

- Open, accepting and positive climates and cultures between all the parties involved;

- The establishment of a stable project portfolio to reduce the risk of not recovering the initial development costs of innovations.

In addition, managers should pay careful attention to the organization and management of all the interrelated processes of design, manufacturing, on-site assembly and other related processes such as procurement, sales and marketing. 
For each of the four conducted studies, their limitations and directions for future research are provided in their respective chapters. A summary of the suggested directions for future research is included in Table 6.4. Some of the early suggestions have already been followed up later in this thesis research. Below, the main directions for future research are summarized.

Table 6.4: Directions for future research

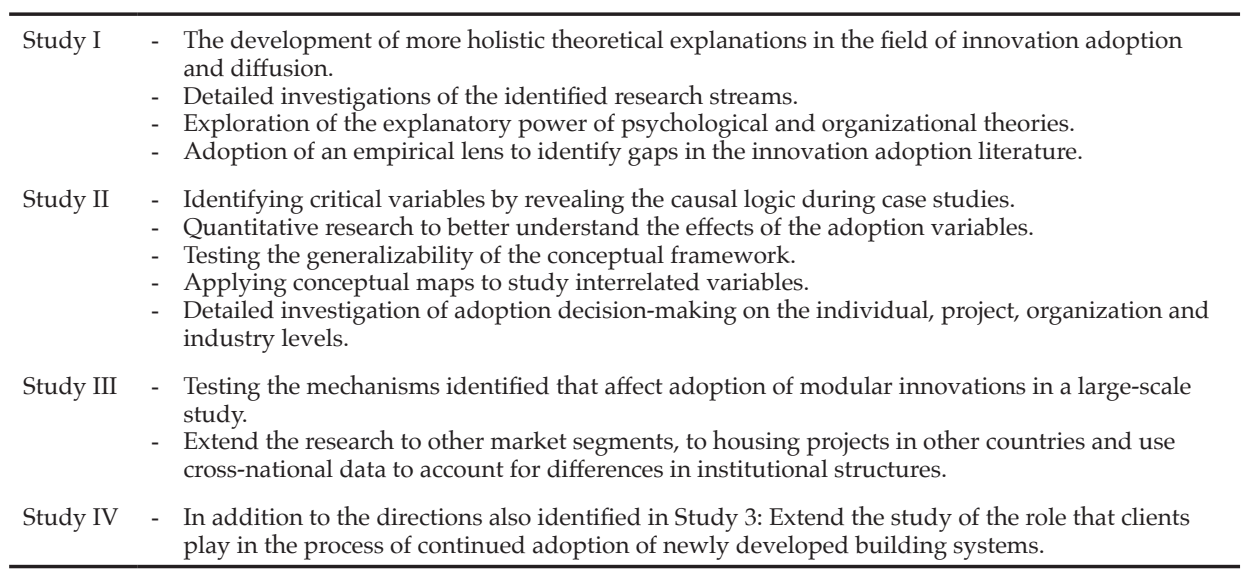

Although the findings in this thesis are based on extensive literature reviews and in-depth multiple-case studies, additional empirical data are needed to generalize the findings. First, the domain of the empirical studies has been the Netherlands. This raises the question as to what extent the findings about innovation adoption in housing projects are generalizable to other countries. Future research could extend the research by investigating the adoption of innovations in the housing sector outside the Netherlands and collect cross-national data. Second, large-scale studies are needed to address the generalizability of the propositions that have been derived and discussed in Chapters 4 and 5. Ideally, such large-scale studies would also have a cross-national character. Third, the focus of the research in this thesis has been on innovation adoption in housing projects. It would be interesting to expand the research to investigate the adoption of innovations in other types of building and civil engineering projects and to also conduct comparative studies. 


\subsection{Conclusion}

This thesis research started with the observation of there being a large shortage of affordable, sustainable and circular houses in the Netherlands, and that solving this requires the adoption of innovative solutions to realize a far-reaching professionalization and industrialization of the housing sector. However, given that the housing sector's innovation roadmap is paved with countless innovations that have not been adopted by the market, a much better insight into the factors that stimulate or hinder innovation adoption was therefore needed. This thesis has hopefully provided such insights, and my hope is that the insights developed and described in this thesis may contribute to increased adoption of effective solutions and to decrease the shortage of affordable, sustainable and circular housing in the Netherlands. 



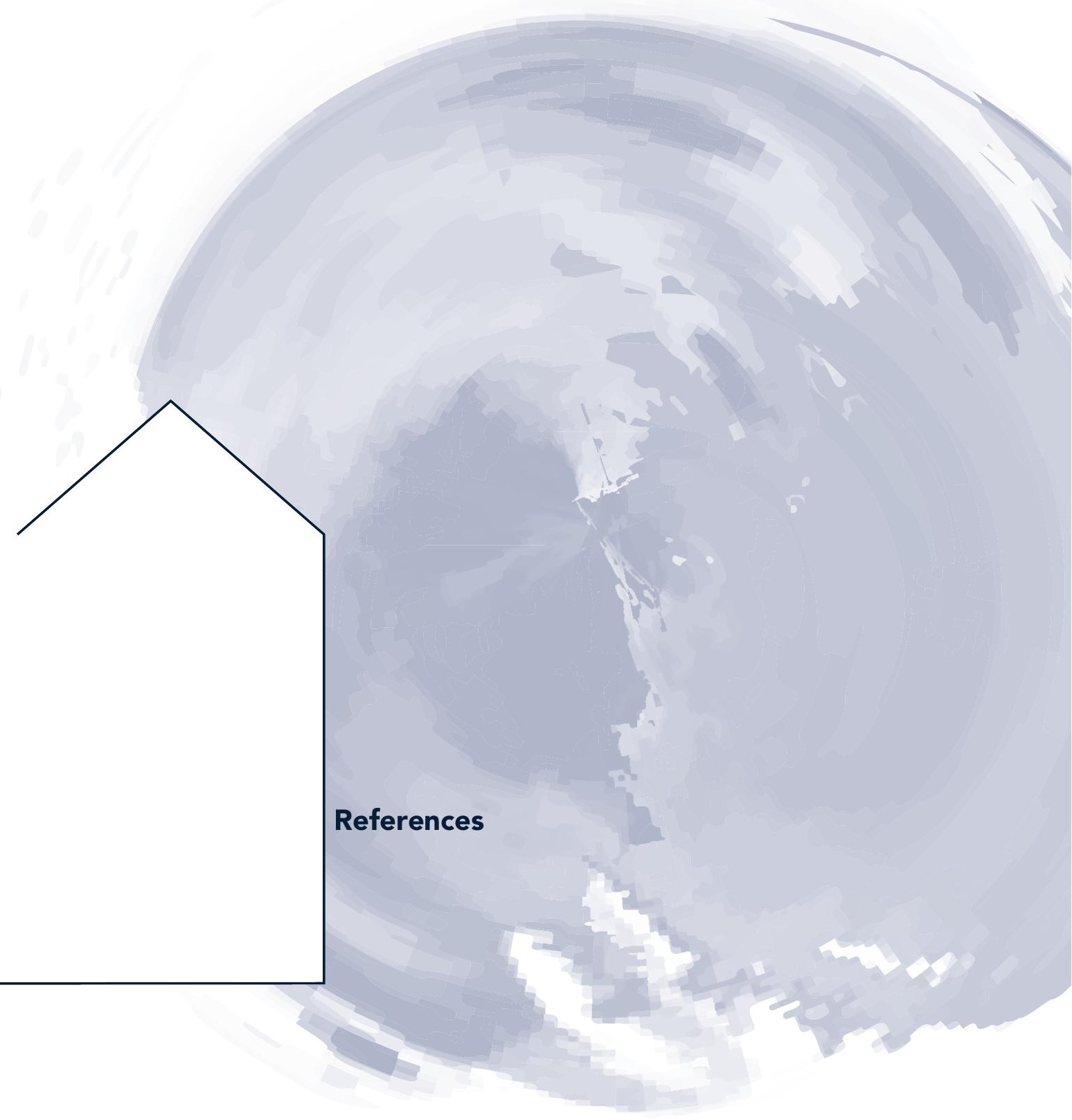


Aarikka-Stenroos, L., Sandberg, B. and Lehtimäki, T., 2014. Networks for the commercialization of innovations: A review of how divergent network actors contribute. Industrial Marketing Management 43, 365-381.

Abdel-Wahab, M., Moore, D. and MacDonald, S. 2011. Exploring the adoption of low carbon technologies by scottish housing associations. International Journal of Low-Carbon Technologies 6, 318-323.

Abrahamson, E., 1991. Managerial fads and fashions: The diffusion and rejection of innovations. Academy of Management Review 16, pp. 586-612.

Abrahamson, E., 1996. Management fashion. Academy of Management Review 21, pp. 254-285.

Abrahamson, E. and Fairchild, G., 1999. Management fashion: Lifecycles, triggers, and collective learning processes. Administrative science quarterly 44, 708-740.

Abrahamson, E. and Rosenkopf, L., 1993. Institutional and competitive bandwagons: Using mathematical modeling as a tool to explore innovation diffusion. Academy of Management Review 18, 487-517.

Abrahamson, E. and Rosenkopf, L., 1997. Social network effects on the extent of innovation diffusion: A computer simulation. Organization Science 8, 289-309.

Achtnicht, M. and Madlener, R., 2014. Factors influencing german house owners' preferences on energy retrofits. Energy Policy 68, 254-263.

Adinyira, E., Kwofie, T. and Quarcoo, F., 2018. Stakeholder requirements for building energy efficiency in mass housing delivery: The house of quality approach. Environment, development and sustainability 20, 1115-1131.

Adnan, N., Nordin, S.M. and Rahman, I., 2017a. Adoption of phev/ev in malaysia: A critical review on predicting consumer behaviour. Renewable and Sustainable Energy Reviews 72, 849-862.

Adnan, N., Nordin, S.M., Rahman, I. and Amini, M.H., 2017b. A market modeling review study on predicting malaysian consumer behavior towards widespread adoption of phev/ev. Environmental Science and Pollution Research 24, 17955-17975.

Adnan, N., Nordin, S.M., Rahman, I., Vasant, P.M. and Noor, A., 2017c. A comprehensive review on theoretical framework based electric vehicle consumer adoption research. International Journal of Energy Research 41, 317-335.

Agarwal, R. and Prasad, J., 1997. The role of innovation characteristics and perceived voluntariness in the acceptance of information technologies. Decision Sciences 28, pp. 557-582.

Agarwal, R. and Prasad, J., 1998. The antecedents and consequents of user perceptions in information technology adoption. Decision support systems 22, pp. 15-29.

Agentschap NL, 2011. Voorbeeldwoningen 2011 - bestaande bouw (dutch national typology brochure). Agentschap NL - NL Energie en Klimaat, Sittard, pp. 47.

Ajzen, I., 1991. The theory of planned behavior Organizational behavior and human decision processes 50, pp. 179-211.

Ajzen, I. and Fishbein, M., 1980. Understanding attitudes and predicting social behavior. Prentice-Hall.
Akinboade, O.A., 2012. Drivers of housing technology adoption in south africa. Journal of Geography and Regional Planning 5, 328-338.

Akmam Syed Zakaria, S., Gajendran, T., Rose, T. and Brewer, G., 2018. Contextual, structural and behavioural factors influencing the adoption of industrialised building systems: A review. Architectural Engineering and Design Management 14, 3-26.

Ali, M.M., Abas, N.H., Affandi, H.M. and Abas, N.A., 2018. Factors impeding the industrialized building system (ibs) implementation of building construction in malaysia. International Journal of Engineering and Technology (UAE) 7, 2209-2212.

Allen, J.D., Towne, S.D., Maxwell, A.E., DiMartino, L., Leyva, B., Bowen, D.J., Linnan, L. and Weiner, B.J., 2017. Measures of organizational characteristics associated with adoption and/or implementation of innovations: A systematic review. BMC health services research 17, 591.

Argote, L. and Greve, H.R., 2007. A behavioral theory of the firm-40 years and counting: Introduction and impact. Organization Science 18, pp. 337-349.

Arif, M. and Davidson, C.H., 2009. The challenge of organizational design for manufactured construction. Construction innovation 9, 42-57.

Arnoldussen, J., Groot, P., Halman, J. and Van Zwet, R., 2017. Innovatie in de bouw: Opgaven en kansen, adviesrapport aan de paritaire organisaties in de bouw (innovation in construction: Challenges and opportunities). EIB en Universiteit Twente, Amsterdam/Enschede, pp. 77.

Arora, A., Forman, C. and Yoon, J.W., 2010. Complementarity and information technology adoption: Local area networks and the internet. Information Economics and Policy 22, 228-242.

Åstebro, T., 2004. Sunk costs and the depth and probability of technology adoption. The Journal of Industrial Economics 52, 381-399.

Attewell, P., 1992. Technology diffusion and organizational learning: The case of business computing. Organization Science 3, 1-19.

AWTI, 2018. Verspreiding, the onderbelichte kant van innovatie (diffusion, the underexposed side of innovation). AWTI, Den Haag, pp. 61.

Azam Haron, N., Abdul-Rahman, H., Wang, C. and Wood, L.C., 2015. Quality function deployment modelling to enhance industrialised building system adoption in housing projects. Total Quality Management \& Business Excellence 26, 703-718.

Azhar, S., Lukkad, M.Y. and Ahmad, I., 2013. An investigation of critical factors and constraints for selecting modular construction over conventional stick-built technique. International journal of construction education and research 9, 203-225.

Baldwin, C. and Clark, K., 1997. Managing in an age of modularity. Harvard Business Review 75, 84.

Baldwin, C.Y. and Clark, K.B., 2000. Design rules, volume 1: The power of modularity. mlt Press.

Banfill, P. and Peacock, A., 2007. Energy-efficient new housing-the uk reaches for sustainability. Building Research \& Information 35, 426-436.

Barbosa, F., Woetzel, J., Mischke, J., Ribeirinho, M.J., Sridhar, M., Parsons, M., Bertram, N. and Brown, S., 2017. Reinventing construction: A route to high productivity. McKinsey, pp. 20. 
Barlow, J., Childerhouse, P., Gann, D., Hong-Minh, S., Naim, M. and Ozaki, R., 2003. Choice and delivery in housebuilding: Lessons from japan for uk housebuilders. Building Research \& Information 31, 134-145.

Barney, J., 1991. Firm resources and sustained competitive advantage. Journal of Management 17, 99-120.

Barreto, I. and Baden-Fuller, C., 2006. To conform or to perform? Mimetic behaviour, legitimacy-based groups and performance consequences. Journal of Management Studies 43, 1559-1581.

Basaglia, S., Caporarello, L., Magni, M. and Pennarola, F., 2009. Environmental and organizational drivers influencing the adoption of voip. Information Systems and E-Business Management 7, 103-118.

Baskerville, R.L. and Myers, M.D., 2009. Fashion waves in information systems research and practice. Mis Quarterly 33, 647-662.

Bass, F., 1969. A new product growth model for consumer durables. Management sciences. Institute for Operations Research and the Management Sciences. Evanston, XV (5).

Bass, F.M., Krishnan, T.V. and Jain, D.C., 1994. Why the bass model fits without decision variables. Marketing science 13, pp. 203-223.

Battisti, G. and Stoneman, P., 2005. The intra-firm diffusion of new process technologies. International Journal of Industrial Organization 23, 1-22.

Baumhof, R., Decker, T., Röder, H. and Menrad, K., 2018. Which factors determine the extent of house owners' energy-related refurbishment projects? A motivation-opportunity-ability approach. Sustainable cities and society 36, 33-41.

Becker, R.M.J., 2017. Adoption of modular innovations in the construction housing studies: An exploratory research to the supplier-contractor relationship, Faculty of Engineering Technology, Construction Management \& Engineering. University of Twente, Enschede.

Beerepoot, M. and Beerepoot, N., 2007. Government regulation as an impetus for innovation: Evidence from energy performance regulation in the dutch residential building sector. Energy Policy 35, 4812-4825.

Beise, M., 2004. Lead markets: Country-specific drivers of the global diffusion of innovations. Research Policy 33, 997-1018.

Beise, M. and Rennings, K., 2005. Lead markets and regulation: A framework for analyzing the international diffusion of environmental innovations. Ecological Economics 52, 5-17.

BEN-NER, A. and Lluis, S., 2011. Learning: What and how? An empirical study of adjustments in workplace organization structure. Industrial Relations: A Journal of Economy and Society 50, 76-108.

Berardi, U., 2013. Stakeholders' influence on the adoption of energy-saving technologies in italian homes. Energy Policy 60, 520-530.

Berry, S., Sharp, A., Hamilton, J. and Killip, G., 2014. Inspiring low-energy retrofits: The influence of 'open home'events. Building Research \& Information 42, 422-433.

Bertram, N., Fuchs, S., Mischke, J., Palter, R., Strube, G. and Woetzel, J., 2019. Modular construction: From projects to products. McKinsey, pp. 34.
Bikhchandani, S., Hirshleifer, D. and Welch, I., 1992. A theory of fads, fashion, custom, and cultural change as informational cascades. Journal of political Economy 100, 992-1026.

Birkinshaw, J., Hamel, G. and Mol, M.J., 2008. Management innovation. Academy of management Review 33, 825-845.

Blackley, D.M. and Shepard III, E.M., 1996. The diffusion of innovation in home building. Journal of Housing Economics 5, 303-322.

Blayse, A.M. and Manley, K., 2004. Key influences on construction innovation. Construction Innovation Information, Process, Management 4, 143-154.

Blismas, N., Pendlebury, M., Gibb, A. and Pasquire, C., 2005. Constraints to the use of off-site production on construction projects. Architectural engineering and design management 1, 153-162.

Blismas, N. and Wakefield, R., 2009. Drivers, constraints and the future of offsite manufacture in australia. Construction innovation 9, 72-83.

Blismas, N., Wakefield, R. and Hauser, B., 2010. Concrete prefabricated housing via advances in systems technologies: Development of a technology roadmap. Engineering, construction and architectural management 17, 99-110.

Bocquet, R., Brossard, O. and Sabatier, M., 2007 Complementarities in organizational design and the diffusion of information technologies: An empirical analysis. Research Policy 36, 367-386.

Boeije, H., 2009. Analysis in qualitative research. Sage publications.

Boeije, H., 2010. Analysis in qualitative research. SAGE Publications Ltd, London.

Boschman, M., 2016. Bouwen met bytes: Digitalisering, automatisering en robotisering in de bouw (construction with bytes: Digitalization, automation and robotization in construction). ABN-AMRO, Amsterdam.

Boser, R.A. and El-Gafy, M., 2011. Accelerating waste minimization in residential construction: A source separation case study. International Journal of Construction Education and Research 7, 58-70.

Bosma, K.H., D, van; Vos, M., 2000. Housing for the millions, john habraken and the sar (1960-2000). NAI Publishers, Rotterdam.

Bossink, B., 2018. The influence of knowledge flow on sustainable innovation in a project-based industry: From demonstration to limited adoption of eco-innovations. Journal of cleaner production 193, 249-262.

Bossink, B.A., 2015. Demonstration projects for diffusion of clean technological innovation: A review. Clean Technologies and Environmental Policy 17, 1409-1427.

Bossink, B.A., 2017. Demonstrating sustainable energy: A review based model of sustainable energy demonstration projects. Renewable and Sustainable Energy Reviews 77, 1349-1362.

Bossink, B.A.G., 2004. Managing drivers of innovation in construction networks. Journal of Construction Engineering and management 130, 337-345.

Bossle, M.B., de Barcellos, M.D., Vieira, L.M. and Sauvée, L., 2016. The drivers for adoption of eco-innovation. Journal of Cleaner Production $113,861-872$. 
Bourke, J. and Roper, S., 2012. In with the new: The determinants of prescribing innovation by general practitioners in ireland. European Journal of Health Economics 13, pp. 393-407.

Bowers, T., Ganguly, I. and Eastin, I., 2014. Eco-labeled wood products in the us residential construction industry: Architects' awareness and usage of certified wood and green building programs. The Forestry Chronicle 90, 605-613.

Boyack, K.W. and Klavans, R., 2010. Co-citation analysis, bibliographic coupling, and direct citation: Which citation approach represents the research front most accurately? Journal of the American Society for Information Science and Technology 61, pp. 2389-2404.

Boyd, N., Khalfan, M.M. and Maqsood, T., 2012. Offsite construction of apartment buildings. Journal of Architectural Engineering 19, 51-57.

Bresnahan, T.F., Brynjolfsson, E. and Hitt, L.M., 2002. Technology, organization, and the demand for skilled labor, in: Blair, M.M., Kochan, T.A. (Eds.), The new relationship: Human capital in the american corporation. Brookings Institution Press, pp. pp. 145-193, 0815723628, 9780815723622.

Bresnahan, T.F. and Trajtenberg, M., 1995. General purpose technologies 'engines of growth'? Journal of econometrics 65, 83-108.

Bricker, R., 1989. An empirical investigation of the structure of accounting research. Journal of Accounting Research, pp 246-262.

Briner, R.B. and Denyer, D., 2012. Systematic review and evidence synthesis as a practice and scholarship tool. Handbook of evidence-based management: Companies, classrooms and research, 112-129.

Brown, Swan, W. and Chahal, S., 2014. Retrofitting social housing: Reflections by tenants on adopting and living with retrofit technology. Energy Efficiency 7, 641-653.

Brown, J. and Hendry, C., 2009. Public demonstration projects and field trials: Accelerating commercialisation of sustainable technology in solar photovoltaics. Energy Policy 37, 2560-2573.

Brown, L.A., 1981. Innovation diffusion: A new perspective. Methuen.

Brown, L.A. and Eisenhardt, K.M., 1995. Product development: Past research, present findings, and future directions. Academy of Management Review 20, pp. 343-378.

Bruner, G.C. and Kumar, A., 2005. Explaining consumer acceptance of handheld internet devices. Journal of Business Research 58, 553-558.

Bruque, S. and Moyano, J., 2007. Organisational determinants of information technology adoption and implementation in smes: The case of family and cooperative firms. Technovation 27, 241-253.

Brusoni, S., Prencipe, A. and Pavitt, K., 2001. Knowledge specialization, organizational coupling, and the boundaries of the firm: Why do firms know more than they make? Administrative science quarterly 46, 597-621.

Burt, R.S., 1987. Social contagion and innovation: Cohesion versus structural equivalence. American Journal of Sociology, 1287-1335.

Burton, M., Rigby, D. and Young, T., 2003. Modelling the adoption of organic horticultural technology in the uk using duration analysis. Australian Journal of Agricultural and Resource Economics 47, 29-54.
Byambaa, T., Janes, C., Takaro, T. and Corbett, K., 2015. Putting health impact assessment into practice through the lenses of diffusion of innovations theory: A review. Environment, development and sustainability $17,23-40$.

Bygballe, L.E., Håkansson, H. and Ingemansson, M. 2015. An industrial network perspective on innovation in construction. Construction innovation, 89-101.

Bygballe, L.E. and Ingemansson, M., 2014. The logic of innovation in construction. Industrial Marketing Management 43, 512-524.

BZK, 2018a. Aanbiedingsbrief bij nationale woonagenda 2018-2021 (supporting letter national housing agenda 2018-2021), Ministerie van Binnenlandse Zaken en Koninkrijks Relaties, Den Haag

BZK, 2018b. Nationale woonagenda 2018-2021 (national housing agenda 2018-2021), Ministerie van Binnenlandse Zaken en Koninkrijks Relaties, Den Haag

BZK, 2019. Cijfers over wonen en bouwen 2019 (housing statistics 2019). Ministerie van Binnenlandse Zaken en Koninkrijks Relaties, Den Haag, pp. 136.

Cabigiosu, A. and Camuffo, A., 2012. Beyond the "mirroring" hypothesis: Product modularity and interorganizational relations in the air conditioning industry. Organization Science 23, 686-703.

Campagnolo, D. and Camuffo, A., 2010. The concept of modularity in management studies: $A$ literature review. International Journal of Management Reviews 12, 259-283.

Campbell, R., Pound, P., Pope, C., Britten, N., Pill, R., Morgan, M. and Donovan, J., 2003. Evaluating meta-ethnography: A synthesis of qualitative research on lay experiences of diabetes and diabetes care. Social science \& medicine 56, 671-684.

Candas, B., Jobin, G., Dubé, C., Tousignant, M., Abdeljelil, A.B., Grenier, S. and Gagnon, M.-P., 2016. Barriers and facilitators to implementing continuous quality improvement programs in colonoscopy services: A mixed methods systematic review. Endoscopy international open 4, E118.

Carletto, C., Kirk, A., Winters, P.C. and Davis, B., 2010. Globalization and smallholders: The adoption, diffusion, and welfare impact of non-traditional export crops in guatemala. World Development 38, pp. 814-827.

Centrone, F., Goia, A. and Salinelli, E., 2007. Demographic processes in a model of innovation diffusion with a dynamic market. Technological Forecasting and Social Change 74, 247-266.

Chang, M.K. and Cheung, W., 2001. Determinants of the intention to use internet/www at work: $A$ confirmatory study. Information \& Management 39, pp. 1-14.

Chatterjee, D., Grewal, R. and Sambamurthy, V., 2002. Shaping up for e-commerce: Institutional enablers of the organizational assimilation of web technologies. MIS quarterly, 65-89.

Chatterjee, R.A. and Eliashberg, J., 1990. The innovation diffusion process in a heterogeneous population: A micromodeling approach. Management science 36, pp. 1057-1079. 
Chau, P.Y. and Tam, K.Y., 1997. Factors affecting the adoption of open systems: An exploratory study. MIS quarterly, 1-24.

Cheaitou, A., Larbi, R. and Al Housani, B., 2018. Decision making framework for tender evaluation and contractor selection in public organizations with risk considerations. Socio-Economic Planning Sciences.

Cheng, H.-L., 2010. Seeking knowledge or gaining legitimacy? Role of social networks on new practice adoption by oem suppliers. Journal of Business Research 63, 824-831.

Choi, M. and Erikstad, S.O., 2017. A module configuration and valuation model for operational flexibility in ship design using contract scenarios. Ships and Offshore Structures 12, 1127-1135.

Christie, L., Donn, M. and Walton, D., 2011. The 'apparent disconnect'towards the adoption of energy-efficient technologies. Building Research \& Information 39, 450-458

Chwelos, P., Benbasat, I. and Dexter, A.S., 2001. Research report: Empirical test of an edi adoption model. Information systems research 12, 304-321.

Cohen, W.M. and Levinthal, D.A., 1989. Innovation and learning: The two faces of $r \& d$. The Economic Journal, 569-596.

Cohen, W.M. and Levinthal, D.A., 1990. Absorptive capacity: A new perspective on learning and innovation. Administrative science quarterly, 128-152.

Colfer, L.J. and Baldwin, C.Y., 2016. The mirroring hypothesis: Theory, evidence, and exceptions. Industrial and Corporate Change 25, 709-738.

Colombo, M.G., Croce, A. and Grilli, L., 2013. Ict services and small businesses' productivity gains: An analysis of the adoption of broadband internet technology. Information Economics and Policy 25, 171-189.

Compagni, A., Mele, V. and Ravasi, D., 2015. How early implementations influence later adoptions of innovation: Social positioning and skill reproduction in the diffusion of robotic surgery. Academy of Management Journal 58, 242-278.

Conley, T.G. and Udry, C.R., 2010. Learning about a new technology: Pineapple in ghana. American Economic Review 100, 35-69.

Cook, D.J., Mulrow, C.D. and Haynes, R.B., 1997 Systematic reviews: Synthesis of best evidence for clinical decisions. Annals of internal medicine 126, pp. 376-380.

Cooper, R.B. and Zmud, R.W., 1990. Information technology implementation research: A technological diffusion approach. Management science 36, pp. 123-139.

Corner, D., Fawcett, R. and Allison, K., 2005. Using modern methods of construction to build homes more quickly and efficiently. London.

Crabtree, L. and Hes, D., 2009. Sustainability uptake in housing in metropolitan australia: An institutional problem, not a technological one. Housing Studies 24, 203-224.

Craig, D. and Roy, R., 2004. Developing a customer-focused culture in the speculative house-building industry. Total Quality Management \& Business Excellence 15, 73-87.

Cresswell, K. and Sheikh, A., 2013. Organizational issues in the implementation and adoption of health information technology innovations: An interpretative review. International journal of medical informatics 82 , e73-e86.
Cyert, R.M. and March, J.G., 1963. A behavioral theory of the firm. Englewood Cliffs, NJ 2.

D'Emden, F.H., Llewellyn, R.S. and Burton, M.P., 2006. Adoption of conservation tillage in australian cropping regions: An application of duration analysis. Technological Forecasting and Social Change 73, pp. 630-647.

da Rocha, C., Formoso, C. and Tzortzopoulos, P. 2015. Adopting product modularity in house building to support mass customisation. Sustainability 7, 4919-4937.

da Rocha, C.G. and Kemmer, S., 2018. Integrating product and process design in construction. Construction Management and Economics 36, 535-543.

Daft, R.L., 1978. A dual-core model of organizational innovation. Academy of Management Journal 21, 193-210.

Daget, Y.T. and Zhang, H., 2018. Decision-making for evaluation and selection of suitable industrialized housing system. International Journal 15, 167-173.

Dainty, A.R., Cheng, M.-I. and Moore, D.R., 2005. Competency-based model for predicting construction project managers' performance. Journal of management in engineering 21, 2-9.

Damanpour, F., 1987. The adoption of technological, administrative, and ancillary innovations: Impact of organizational factors. Journal of Management 13, pp. 675-688.

Damanpour, F., 1991. Organizational innovation: A meta-analysis of effects of determinants and moderators. Academy of Management Journal, pp. 555-590.

Damanpour, F., 1992. Organizational size and innovation. Organization Studies 13, pp. 375-402.

Damanpour, F. and Schneider, M., 2006. Phases of the adoption of innovation in organizations: Effects of environment, organization and top managers1. British Journal of Management 17, 215-236.

Damanpour, F., Walker, R.M. and Avellaneda, C.N. 2009. Combinative effects of innovation types and organizational performance: A longitudinal study of service organizations. Journal of management studies 46, pp. 650-675.

Daniel, E., Myers, A. and Dixon, K., 2012. Adoption rationales of new management practices. Journal of Business Research 65, 371-380.

David, P.A., 1985. Clio and the economics of qwerty. The American economic review 75, 332-337.

Davies, S.W., 1979. Inter-firm diffusion of process innovations. European Economic Review 12, pp. 299-317.

Davila, A., Foster, G. and Li, M., 2009. Reasons for management control systems adoption: Insights from product development systems choice by early-stage entrepreneurial companies. Accounting Organizations and Society 34, 322-347.

Davis, F.D., 1989. Perceived usefulness, perceived ease of use, and user acceptance of information technology. Mis Quarterly, pp. 319-340.

Davis, F.D., Bagozzi, R.P. and Warshaw, P.R., 1989. User acceptance of computer technology: A comparison of two theoretical models. Management science 35, pp. 982-1003. 
Davis Jr, F.D., 1986. A technology acceptance model for empirically testing new end-user information systems: Theory and results. Massachusetts Institute of Technology.

De Bruyn, A. and Lilien, G.L., 2008. A multi-stage model of word-of-mouth influence through viral marketing. International Journal of Research in Marketing 25, 151-163.

De Grood, C., Raissi, A., Kwon, Y. and Santana, M.J., 2016. Adoption of e-health technology by physicians: A scoping review. Journal of multidisciplinary healthcare $9,335$.

Del Aguila-Obra, A.R. and Padilla-Melendez, A., 2006. Organizational factors affecting internet technology adoption. Internet Research 16, 94110

Dewar, R.D. and Dutton, J.E., 1986. The adoption of radical and incremental innovations: An empirical analysis. Management science 32, pp. 1422-1433.

Dewick, P. and Miozzo, M., 2002. Sustainable technologies and the innovation-regulation paradox. Futures 34, 823-840.

Diagne, A. and Demont, M., 2007. Taking a new look at empirical models of adoption: Average treatment effect estimation of adoption rates and their determinants. Agricultural Economics 37, 201-210.

Dicken, P. and Malmberg, A., 2001. Firms in territories: A relational perspective. Economic Geography $77,345-363$.

Dickerson, M.D. and Gentry, J.W., 1983. Characteristics of adopters and non-adopters of home computers. Journal of consumer research, pp. 225-235.

Dieperink, C., Brand, I. and Vermeulen, W., 2004. Diffusion of energy-saving innovations in industry and the built environment: Dutch studies as inputs for a more integrated analytical framework. Energy Policy 32, 773-784.

Dimaggio, P. and Powell, W., 1983. The iron cage revisited: Institutional isomorphism and collective rationality in organizational fields. American Sociological Review 48, pp. 147-160.

Doran, D., 2003. Supply chain implications of modularization. International Journal of Operations \& Production Management 23, 316-326.

Doran, D. and Giannakis, M., 2011. An examination of a modular supply chain: A construction sector perspective. Supply Chain Management: An International Journal 16, 260-270.

Dorée, A., Holmen, E. and Caerteling, J., 2003. Co-operation and competition in the constructioin industry of the netherlands, ARCOM nineteenth Annual Conference, Universiyt of Brighton, pp. 817-826.

Doss, C.R., 2006. Analyzing technology adoption using microstudies: Limitations, challenges, and opportunities for improvement. Agricultural Economics 34, 207-219.

Downs, G.W. and Mohr, L.B., 1976. Conceptual issues in the study of innovation. Administrative science quarterly, pp. 700-714.

Duah, D. and Syal, M., 2016. Intelligent decision support system for home energy retrofit adoption. International Journal of Sustainable Built Environment 5, 620-634.
Dubois, A. and Gadde, L., 2000. Supply strategy and network effects - purchasing behaviour in the construction industry. Purchasing \& Supply Management 6, 207-215.

Dubois, A. and Gadde, L., 2002. The construction industry as a loosely coupled system: Implications for productivity and innovation. Construction Management and Economics 20, 621-631.

Easingwood, C.J., Mahajan, V. and Muller, E., 1983. A nonuniform influence innovation diffusion model of new product acceptance. Marketing science 2, pp. 273-295.

ECSO, 2017. Improving the human capital basis. European Construction Sector Observatory, Brussels.

ECSO, 2018a. Improving energy and resource efficiency. European Construction Sector Observatory, Brussels.

ECSO, 2018b. Stimulating favourable investment conditions. European Construction Sector Observatory, Brussels.

Eden, C., Ackermann, F. and Cropper, S., 1992. The analysis of cause maps. Journal of management studies 29, 309-324.

Egan, J., 1998. Rethinking construction: The report of the construction task force to the deputy prime minister, john prescott, on the scope for improving the quality and efficiency of uk construction. Department of the Environment, Transport and the Regions, London.

Egmond, Jonkers, R. and Kok, G., 2005. A strategy to encourage housing associations to invest in energy conservation. Energy Policy 33, 2374-2384.

Egmond, Jonkers, R. and Kok, G., 2006a. A strategy and protocol to increase diffusion of energy related innovations into the mainstream of housing associations. Energy Policy 34, 4042-4049.

Egmond, C., Jonkers, R. and Kok, G., 2006b. A strategy and protocol to increase diffusion of energy related innovations into the mainstream of housing associations. Energy Policy 34, 4042-4049.

Eisenhardt, K.M., 1989. Building theories from case study research. Academy of Management Review, 532-550.

Elazouni, A.M., Ali, A.E. and Abdel-Razek, R.H., 2005. Estimating the acceptability of new formwork systems using neural networks. Journal of Construction Engineering and management 131, 33-41.

Ellabban, O. and Abu-Rub, H., 2016. Smart grid customers' acceptance and engagement: An overview. Renewable and Sustainable Energy Reviews 65, 1285-1298.

Ellen MacArthur Foundation, 2015a. Growth within: A cricular economy vissiion for a competitive europe. Ellen MacArthur Foundation.

Ellen MacArthur Foundation, 2015b. Towards a circular economy: Business rationale for an accelerated transition. Ellen MacArthur Foundation.

Ellram, L.M., Tate, W.L. and Carter, C.R., 2007. Product-process-supply chain: An integrative approach to three-dimensional concurrent engineering. International Journal of Physical Distribution \& Logistics Management 37, 305-330. 
Engström and Hedgren, 2012. Sustaining inertia? Construction clients' decision-making and information-processing approach to industrialized building innovations. Construction innovation 12, 393-413.

Erumban, A.A. and de Jong, S.B., 2006. Cross-country differences in ict adoption: A consequence of culture? Journal of World Business 41, 302-314.

Estem, K.S., Catania, J. and Klausner, J.D., 2016. Hiv self-testing: A review of current implementation and fidelity. Current HIV/AIDS Reports 13, 107-115.

Etzion, D. and Ferraro, F., 2010. The role of analogy in the institutionalization of sustainability reporting. Organization Science 21, 1092-1107.

Eurostat, 2019a. Greenhouse gas emission statistics - ari emissions accounts, statistics explained. EU Eurostat.

Eurostat, 2019b. Housing statistics, statistics explained. EU Eurostat.

EZK, 2018. Kabinetsreactie awti-advies 'verspreiding, de onderbelichte kant van innovatie' (letter government response awti advice "diffusion, the underexposed side of innovation"), Ministerie van Economische Zaken, Den Haag

Fabiani, S., Schivardi, F. and Trento, S., 2005. Ict adoption in italian manufacturing: Firm-level evidence. Industrial and Corporate Change 14 225-249.

Faessen, W., Gopal, K., Van Leeuwen, G. and Omtzigt, D., 2017. Primos 2017, prognose van bevolking, huishoudens en woningbehoeft 2017 2050 (primos 2017, demographics, households and living arrangement projections 2017-2050). ABF Research, Delft, pp. 77

Fagerberg, J. and Verspagen, B., 2007. Innovation growth and economic development: Have the conditions for catch-up changed? International Journal of Technological Learning, Innovation and Development 1, pp. 13-33.

Falagas, M.E., Pitsouni, E.I., Malietzis, G.A. and Pappas, G., 2008. Comparison of pubmed, scopus, web of science, and google scholar: Strengths and weaknesses. The FASEB journal 22, 338-342.

Farrell, J. and Saloner, G., 1985. Standardization, compatibility, and innovation. The RAND Journal of Economics, pp. 70-83.

Farrell, J. and Saloner, G., 1986. Installed base and compatibility: Innovation, product preannouncements, and predation. The American economic review, pp. 940-955.

Fawcett, T., 2014. Exploring the time dimension of low carbon retrofit: Owner-occupied housing. Building Research \& Information 42, 477-488.

Feder, G., Just, R.E. and Zilberman, D., 1985. Adoption of agricultural innovations in developing countries: A survey. Economic development and cultural change 33, pp. 255-298.

Feder, G. and Umali, D.L., 1993. The adoption of agricultural innovations: A review. Technological Forecasting and Social Change 43, pp. 215-239.

Feldman, M.P., Kogler, D.F. and Rigby, D.L., 2015. Rknowledge: The spatial diffusion and adoption of rdna methods. Regional studies 49, 798-817.
Femenias, P., 2004. Demonstration projects for sustainable building: Towards a strategy for sustainable development in the building sector based on swedish and dutch experience, Department of Built Environment \& Sustainable Development, School of Architecture, Centre for Environment and Sustainability. Chalmers University of Technology, Göteborg, p. 288.

Femenías, P., Mjörnell, K. and Thuvander, L., 2018. Rethinking deep renovation: The perspective of rental housing in sweden. Journal of cleaner production 195, 1457-1467.

Fichman, R.G. and Kemerer, C.F., 1993. Adoption of software engineering process innovations: The case of object orientation. Sloan management review 34, pp. 7-22.

Fichman, R.G. and Kemerer, C.F., 1997. The assimilation of software process innovations: An organizational learning perspective. Management science 43 , 1345-1363.

Fichman, R.G. and Kemerer, C.F., 1999. The illusory diffusion of innovation: An examination of assimilation gaps. Information systems research 10, 255-275

Fine, C.H., 2000. Clockspeed-based strategies for supply chain design. Production and operations management 9, 213-221.

Fine, C.H., Golany, B. and Naseraldin, H., 2005 Modeling tradeoffs in three-dimensional concurrent engineering: A goal programming approach Journal of Operations Management 23, 389-403.

Finnimore, B., 1989. Houses from the factory : System building and the welfare state ; 1942-74. Rivers Oram Pr., London.

Fishbein, M. and Ajzen, I., 1975. Belief, attitude, intention and behavior: An introduction to theory and research. Reading, Mass. : Addison-Wesley, 1975.

Forman, C., 2005. The corporate digital divide: Determinants of internet adoption. Management Science 51, 641-654.

Fornerino, M., 2003. Internet adoption in france. Service Industries Journal 23, 119-135.

Foster, A.D. and Rosenzweig, M.R., 1995. Learning by doing and learning from others: Human capital and technical change in agriculture. Journal of political Economy, pp. 1176-1209.

Frambach, R.T. and Schillewaert, N., 2002. Organizational innovation adoption: A multi-level framework of determinants and opportunities for future research. Journal of Business Research 55, 163-176.

Franke, N., Keinz, P. and Schreier, M., 2008. Complementing mass customization toolkits with user communities: How peer input improves customer self? design. Journal of Product Innovation Management 25, 546-559.

Fudenberg, D. and Tirole, J., 1985. Preemption and rent equalization in the adoption of new technology. The Review of Economic Studies 52, pp. 383-401.

Fuentelsaz, L., Gomez, J. and Palomas, S., 2009. The effects of new technologies on productivity: An intrafirm diffusion-based assessment. Research Policy 38, 1172-1180.

Fuentelsaz, L., Gomez, J. and Polo, Y., 2003. Intrafirm diffusion of new technologies: An empirical application. Research Policy 32, 533-551. 
Furrer, O., Thomas, H. and Goussevskaia, A., 2008. The structure and evolution of the strategic management field: A content analysis of 26 years of strategic management research. International Journal of Management Reviews 10, 1-23.

Gadde, L.E. and Dubois, A., 2010. Partnering in the construction industry-problems and opportunities. Journal of Purchasing and Supply Management $16,254-263$

Gagnon, M.-P., Ngangue, P., Payne-Gagnon, J. and Desmartis, M., 2015. M-health adoption by healthcare professionals: A systematic review. Journal of the American Medical Informatics Association 23, 212-220.

Gambatese, J. and Hallowell, M., 2011a. Enabling and measuring innovation in the construction industry. Construction Management and Economics 29, 553-567.

Gambatese, J. and Hallowell, M., 2011b. Factors that influence the development and diffusion of technical innovations in the construction industry. Construction Management and Economics 29, 507-517.

Gan, X., Zuo, J., Ye, K., Skitmore, M. and Xiong, B., 2015. Why sustainable construction? Why not? An owner's perspective. Habitat International 47, 61-68.

Ganguly, I., Koebel, C.T. and Cantrell, R.A., 2010. A categorical modeling approach to analyzing new product adoption and usage in the context of the building-materials industry. Technological Forecasting and Social Change 77, 662-677.

Gangwar, H., Date, H. and Raoot, A., 2014. Review on it adoption: Insights from recent technologies. Journal of Enterprise Information Management 27, 488-502.

Gann, D., 1996. Construction as a manufacturing process? Similarities and differences between industrialized housing and car production in japan. Construction Management \& Economics 14, 437-450.

Gann, D. and Salter, A., 2000. Innovation in project-based, service-enhanced firms: The construction of complex products and systems. Research policy 29, 955-972.

Garber, T., Goldenberg, J., Libai, B. and Muller, E., 2004. From density to destiny: Using spatial dimension of sales data for early prediction of new product success. Marketing Science 23, 419-428.

Gatignon, H. and Robertson, T.S., 1985. A propositional inventory for new diffusion research. Journal of consumer research, pp. 849-867.

Gatignon, H. and Robertson, T.S., 1989. Technology diffusion: An empirical test of competitive effects. The Journal of Marketing, pp. 35-49.

Geels, F.W. and Schot, J., 2007. Typology of sociotechnical transition pathways. Research policy 36, 399-417.

George, A.L. and Bennet, A., 2005. Case studies and theory development in the social sciences. MIT PRess, Cambridge, Massachusetts.

Geroski, P.A., 2000. Models of technology diffusion. Research policy 29, pp. 603-625.

Gerring, J., 2007. Case study research: Principles and practices. Cambridge University Press, New York.
Gibb, A.G., 1999. Off-site fabrication: Prefabrication, pre-assembly and modularisation. John Wiley \& Sons.

Gibb, A.G., 2001. Standardization and pre-assembly-distinguishing myth from reality using case study research. Construction Management \& Economics 19, 307-315.

Gomez, J. and Vargas, P., 2009. The effect of financial constraints, absorptive capacity and complementarities on the adoption of multiple process technologies. Research Policy 38, 106-119.

Goodier and Gibb, 2007a. Future opportunities for offsite in the uk. Construction Management and Economics 25, 585-595.

Goodier, C. and Gibb, A., 2007b. Future opportunities for offsite in the uk. Construction Management and Economics 25, 585-595.

Goodwin, P., Meeran, S. and Dyussekeneva, K. 2014. The challenges of pre-launch forecasting of adoption time series for new durable products. International Journal of Forecasting 30, 1082-1097.

Gosling, J., Pero, M., Schoenwitz, M., Towill, D. and Cigolini, R., 2016. Defining and categorizing modules in building projects: An international perspective. Journal of Construction Engineering and management 142, 04016062.

Graham, E. and Warren-Myers, G., 2019. Investigating the efficacy of a professional education program in promoting sustainable residential construction practices in australia. Journal of cleaner production 210, 1238-1248.

Grandon, E.E. and Pearson, J.M., 2004. Electronic commerce adoption: An empirical study of small and medium us businesses. Information \& management 42, 197-216.

Granovetter, M.S., 1973. The strength of weak ties. American Journal of Sociology, 1360-1380.

Greenhalgh, C. and Rogers, M., 2006. The value of innovation: The interaction of competition, $r \& d$ and ip. Research policy 35, 562-580.

Greenhalgh, T., Robert, G., Macfarlane, F., Bate, P. and Kyriakidou, O., 2004. Diffusion of innovations in service organizations: Systematic review and recommendations. Milbank Quarterly 82, pp. 581-629.

Greenhalgh, T., Robert, G., Macfarlane, F., Bate, P., Kyriakidou, O. and Peacock, R., 2005. Storylines of research in diffusion of innovation: A meta-narrative approach to systematic review. Social science \& medicine 61, pp. 417-430.

Greve, H.R., 2009. Bigger and safer: The diffusion of competitive advantage. Strategic Management Journal 30, 1-23.

Greve, H.R., 2011. Fast and expensive: The diffusion of a disappointing innovation. Strategic Management Journal 32, 949-968.

Griliches, Z., 1957. Hybrid corn: An exploration in the economics of technological change. Econometrica, Journal of the Econometric Society, pp. 501-522.

Grimscheid, G. and Scheublin, F., 2010. New perspectives in industrialisation in construction - a state-of-the-art report. Construction", C.T.G.I.i.

Grover, V., 1993. An empirically derived model for the adoption of customer-based interorganizational systems. Decision sciences 24, 603-640.

Gupta, A.K., Tesluk, P.E. and Taylor, M.S., 2007. Innovation at and across multiple levels of analysis. Organization Science 18, pp. 885-897. 
Guseo, R. and Guidolin, M., 2009. Modelling a dynamic market potential: A class of automata networks for diffusion of innovations. Technological Forecasting and Social Change 76, 806-820.

Guseo, R. and Guidolin, M., 2011. Market potential dynamics in innovation diffusion: Modelling the synergy between two driving forces. Technological Forecasting and Social Change 78, 13-24.

Haavik, T., Mlecnik, E. and Rødsjø, A., 2012. From demonstration projects to volume market of sustainable construction. Energy Procedia 30, 1411-1421.

Habraken, N.J. and Teicher, J., 1972. Supports: An alternative to mass housing.

Haines, V. and Mitchell, V., 2014. A persona-based approach to domestic energy retrofit. Building Research \& Information 42, 462-476.

Hall, D.M., Algiers, A. and Levitt, R.E., 2018. Identifying the role of supply chain integration practices in the adoption of systemic innovations. Journal of management in engineering 34, 04018030.

Halman, J.I.M., Hofer, A.P. and Van Vuuren, W., 2003. Platform?driven development of product families: Linking theory with practice. Journal of Product Innovation Management 20, 149-162.

Halman, J.I.M., Voordijk, J.T. and Reymen, I.M.M.J., 2008. Modular approaches in dutch house building: An exploratory survey. Housing Studies 23, 781-799.

Hamid, Z., Kamar, K.A.M., Zain, M., Ghani, K. and Rahim, A.H.A., 2008. Industrialized building system (ibs) in malaysia: The current state and r\&d initiatives. Malaysian Construction Research Journal (MCRJ) 2, 1-13.

Hanafizadeh, P., Keating, B.W. and Khedmatgozar, H.R., 2014. A systematic review of internet banking adoption. Telematics and informatics 31, 492-510.

Hannan, T.H. and McDowell, J.M., 1984. The determinants of technology adoption: The case of the banking firm. The RAND Journal of Economics, 328-335.

Hartley, A. and Blagden, A., 2007. Current practices and future potential in modern methods of construction. Programme, W.R.A., Banbury, UK.

Harty, C., 2005. Innovation in construction: A sociology of technology approach. Building Research \& Information 33, 512-522.

Hasler, K., Olfs, H.-W., Omta, O. and Bröring, S., 2017. Drivers for the adoption of different eco-innovation types in the fertilizer sector: A review. Sustainability 9, 2216.

Hauge, Å.L., Thomsen, J. and Löfström, E., 2013. How to get residents/owners in housing cooperatives to agree on sustainable renovation. Energy Efficiency 6, 315-328.

Haunschild, P.R. and Miner, A.S., 1997. Modes of interorganizational imitation: The effects of outcome salience and uncertainty. Administrative science quarterly, 472-500.

Hedgren, E. and Stehn, L., 2014. The impact of clients' decision-making on their adoption of industrialized building. Construction Management and Economics 32, 126-145.

Heidenreich, M., 2009. Innovation patterns and location of european low-and medium-technology industries. Research policy 38, 483-494.
Heiskanen, E., Nissilä, H. and Lovio, R., 2015 Demonstration buildings as protected spaces for clean energy solutions-the case of solar building integration in finland. Journal of Cleaner Production $109,347-356$.

Hekkert, M.P., Suurs, R.A., Negro, S.O., Kuhlmann, S. and Smits, R.E., 2007. Functions of innovation systems: A new approach for analysing technological change. Technological forecasting and social change 74, 413-432.

Henderson, R.M. and Clark, K.B., 1990. Architectural innovation: The reconfiguration of existing product technologies and the failure of established firms. Administrative science quarterly, 9-30.

Hirsch-Kreinsen, H., 2008. "Low-technology": A forgotten sector in innovation policy. Journal of technology management \& innovation 3, 11-20.

Hobday, M., 1998. Product complexity, innovation and industrial organisation. Research policy 26 , 689-710.

Hobday, M., 2000. The project-based organisation: An ideal form for managing complex products and systems? Research policy 29, 871-893.

Hofer, A.P. and Halman, J.I.M, 2005. The potential of layout platforms for modular complex products and systems. Journal of Engineering Design 16, 237-255

Hofman, E., 2010. Modular and architectural innovation in loosely coupled networks: Matching customer requirements, product architecture, and supplier networks, Faculty of Engineering Technology, Construction Management and Engineering. University of Twente, Enschede, p. 219.

Hofman, E., Voordijk, H. and Halman, J., 2009. Matching supply networks to a modular product architecture in the house-building industry. Building Research \& Information 37, 31-42.

Hofstede, G.H. and Hofstede, G., 2001. Culture's consequences: Comparing values, behaviors, institutions and organizations across nations. Sage.

Hoicka, C.E. and Parker, P., 2018. Assessing the adoption of the house as a system approach to residential energy efficiency programs. Energy Efficiency 11, 295-313.

Hojnik, J. and Ruzzier, M., 2016. What drives eco-innovation? A review of an emerging literature. Environmental Innovation and Societal Transitions 19, 31-41.

Hollenstein, H. and Woerter, M., 2008. Inter-and intra-firm diffusion of technology: The example of e-commerce: An analysis based on swiss firm-level data. Research Policy 37, 545-564.

Holt, G., 2010. Contractor selection innovation: Examination of two decades' published research. Construction innovation 10, 304-328.

Hong, S.-J. and Tam, K.Y., 2006. Understanding the adoption of multipurpose information appliances: The case of mobile data services. Information Systems Research 17, pp. 162-179.

Hong, W.Y. and Zhu, K., 2006. Migrating to internet-based e-commerce: Factors affecting e-commerce adoption and migration at the firm level. Information \& Management 43, 204-221.

Hoppe, T., 2012. Adoption of innovative energy systems in social housing: Lessons from eight large-scale renovation projects in the netherlands. Energy Policy 51, 791-801. 
Hsu, C.-L., Lu, H.-P. and Hsu, H.-H., 2007. Adoption of the mobile internet: An empirical study of multimedia message service (mms). Omega 35, pp. 715-726.

Hung, S.-Y., Chen, C.C. and Lee, W.-J., 2009. Moving hospitals toward e-learning adoption: An empirical investigation. Journal of Organizational Change Management 22, 239-256.

Hwang, B.-G., Shan, M. and Looi, K.-Y., 2018. Key constraints and mitigation strategies for prefabricated prefinished volumetric construction. Journal of Cleaner Production 183, 183-193.

lacovou, C.L., Benbasat, I. and Dexter, A.S., 1995. Electronic data interchange and small organizations: Adoption and impact of technology. Mis Quarterly, 465-485.

Im, J., Seo, Y., Cetin, K.S. and Singh, J., 2017. Energy efficiency in us residential rental housing: Adoption rates and impact on rent. Applied Energy 205, 1021-1033.

Ingebrigtsen, T., Georgiou, A., Clay-Williams, R., Magrabi, F., Hordern, A., Prgomet, M., Li, J., Westbrook, J. and Braithwaite, J., 2014. The impact of clinical leadership on health information technology adoption: Systematic review. International journal of medical informatics 83, 393-405.

Innis, J., Dryden-Palmer, K., Perreira, T. and Berta, W., 2015. How do health care organizations take on best practices? A scoping literature review. International journal of evidence-based healthcare 13, 254-272.

lyengar, R., Van den Bulte, C. and Valente, T.W., 2011. Opinion leadership and social contagion in new product diffusion. Marketing Science 30, 195-212.

Jaca, C., Santos, J., Errasti, A. and Viles, E., 2012. Lean thinking with improvement teams in retail distribution: A case study. Total Quality Management \& Business Excellence 23, 449-465.

Jaffe, A.B., Newell, R.G. and Stavins, R.N., 2005. A tale of two market failures: Technology and environmental policy. Ecological Economics 54, 164-174.

Jayaram, J. and Vickery, S., 2018. The role of modularity in the supply chain context: Current trends and future research directions. Taylor \& Francis.

Jensen, P., 2014. Configuration of platform architectures in construction, Department of Civil, Enviromental and Natural Resources Engineering. Luleå tekniska universitet, LULEÅ.

Jensen, R., 1982. Adoption and diffusion of an innovation of uncertain profitability. Journal of economic theory 27, pp. 182-193.

Jeyaraj, A., Rottman, J.W. and Lacity, M.C., 2006. A review of the predictors, linkages, and biases in it innovation adoption research. Journal of Information Technology 21, 1-23.

Kahneman, D., Knetsch, J.L. and Thaler, R.H., 1991. Anomalies: The endowment effect, loss aversion, and status quo bias. The journal of economic perspectives 5, pp. 193-206.
Kamar, K., Alshawi, M., Hamid, Z., Nawi, M., Haron, A. and Abdullah, M., 2009. Industrialized building system (ibs): Revisiting the issues on definition, classification and the degree of industrialization. CIRAIC. Kuala Lumpur.

Kamar, K.A.M. and Hamid, Z.A., 2011. Supply chain strategy for contractor in adopting industrialized building system (ibs). Australian Journal of Basic and Applied Sciences 5, 2552-2557.

Kapoor, K.K., Dwivedi, Y.K. and Williams, M.D., 2014. Rogers' innovation adoption attributes: A systematic review and synthesis of existing research. Information Systems Management 31, 74-91.

Karahanna, E., Agarwal, R. and Angst, C.M., 2006. Reconceptualizing compatibility beliefs in technology acceptance research. Mis Quarterly, pp. 781-804.

Karahanna, E., Straub, D.W. and Chervany, N.L., 1999. Information technology adoption across time: A cross-sectional comparison of pre-adoption and post-adoption beliefs. Mis Quarterly, pp 183-213.

Karakaya, E., Hidalgo, A. and Nuur, C., 2014. Diffusion of eco-innovations: A review. Renewable and Sustainable Energy Reviews 33, 392-399.

Karakaya, E. and Sriwannawit, P., 2015. Barriers to the adoption of photovoltaic systems: The state of the art. Renewable and Sustainable Energy Reviews 49, 60-66.

Karshenas, M. and Stoneman, P.L., 1993. Rank, stock, order, and epidemic effects in the diffusion of new process technologies: An empirical model. The RAND Journal of Economics, pp. 503-528.

Katz, M.L. and Shapiro, C., 1985. Network externalities, competition, and compatibility. The American economic review 75, pp. 424-440.

Katz, M.L. and Shapiro, C., 1986. Technology adoption in the presence of network externalities. The journal of political economy, pp. 822-841.

Kauffman, R.J. and Li, X., 2005. Technology competition and optimal investment timing: A real options perspective. IEEE Transactions on Engineering Management 52, 15-29.

Keegan, A. and Turner, J.R., 2002. The management of innovation in project-based firms. Long Range Planning 35, 367-388.

Keizer, J.A. and Halman, J.I.M, 2009. Risks in major innovation projects, a multiple case study within a world's leading company in the fast moving consumer goods. International Journal of Technology Management 48, pp. 499-517.

Kelly, P., Hegarty, J., Barry, J., Dyer, K.R. and Horgan, A., 2017. A systematic review of the relationship between staff perceptions of organizational readiness to change and the process of innovation adoption in substance misuse treatment programs. Journal of substance abuse treatment $80,6-25$

Kendall, S.T., J., 2000. Residential open building. E \& FN Spon (Taylor \& Francis Group).

Kereri, J.O. and Adamtey, S., 2019. Rfid use in residential/commercial construction industry. Journal of Engineering, Design and Technology.

Kerr, S. and Newell, R.G., 2003. Policy-induced technology adoption: Evidence from the us lead phasedown. Journal of Industrial Economics 51, 317-343. 
Keupp, M.M., Palmié, M. and Gassmann, O., 2012. The strategic management of innovation: $A$ systematic review and paths for future research. International Journal of Management Reviews 14, pp. 367-390.

Khanagha, S., Volberda, H., Sidhu, J. and Oshri, I., 2013. Management innovation and adoption of emerging technologies: The case of cloud computing. European Management Review 10, 51-67.

Khanassov, V., Vedel, I. and Pluye, P., 2014. Case management for dementia in primary health care: A systematic mixed studies review based on the diffusion of innovation model. Clinical interventions in aging 9, 915

Khong, P.C.B., Holroyd, E. and Wang, W., 2015. A critical review of the theoretical frameworks and the conceptual factors in the adoption of clinical decision support systems. CIN: Computers, Informatics, Nursing 33, 555-570.

Kim, D.O. and Bae, J., 2005. Workplace innovation, employment relations and hrm: Two electronics companies in south korea. International Journal of Human Resource Management 16, 1277-1302.

Kimberly, J.R. and Evanisko, M.J., 1981. Organizational innovation: The influence of individual, organizational, and contextual factors on hospital adoption of technological and administrative innovations. Academy of Management Journal 24, pp. 689-713.

Koebel, C.T., 2008. Innovation in homebuilding and the future of housing. Journal of the American Planning Association 74, 45-58.

Koebel, C.T. and Cavell, M., 2006. Characteristics of innovative production home builders.

Koebel, C.T., McCoy, A.P., Sanderford, A.R., Franck, C.T. and Keefe, M.J., 2015. Diffusion of green building technologies in new housing construction. Energy and Buildings 97, 175-185.

Koebel, C.T., Papadakis, M., Hudson, E. and Cavell, M., 2004. Diffusion of innovation in the residential building industry.

Koundouri, P., Nauges, C. and Tzouvelekas, V., 2006. Technology adoption under production uncertainty: Theory and application to irrigation technology. American Journal of Agricultural Economics 88, pp. 657-670.

Kovacs, A., Van Looy, B. and Cassiman, B., 2015. Exploring the scope of open innovation: A bibliometric review of a decade of research. Scientometrics 104, 951-983.

Kruse, C.S., DeShazo, J., Kim, F. and Fulton, L., 2014. Factors associated with adoption of health information technology: A conceptual model based on a systematic review. JMIR medical informatics 2 .

Kuan, K.K. and Chau, P.Y., 2001. A perception-based model for edi adoption in small businesses using a technology-organization-environment framework. Information \& management 38, 507-521.

Laepple, D., 2010. Adoption and abandonment of organic farming: An empirical investigation of the irish drystock sector. Journal of Agricultural Economics 61, pp. 697-714.

Langlois, R.N. and Robertson, P.L., 1992. Networks and innovation in a modular system: Lessons from the microcomputer and stereo component industries. Research policy 21, 297-313.
Larsen, G.D., 2011. Understanding the early stages of the innovation diffusion process: Awareness, influence and communication networks. Construction Management and Economics 29, 987-1002.

Lee, R.P. and Grewal, R., 2004. Strategic responses to new technologies and their impact on firm performance. Journal of Marketing 68, 157-171.

Lees, T. and Sexton, M., 2014. An evolutionary innovation perspective on the selection of low and zero-carbon technologies in new housing. Building Research \& Information 42, 276-287.

Lefebvre, M., Langrell, S.R. and Gomez-y-Paloma, S., 2015. Incentives and policies for integrated pest management in europe: A review. Agronomy for sustainable development 35, 27-45.

Legris, P., Ingham, J. and Collerette, P., 2003. Why do people use information technology? A critical review of the technology acceptance model. Information \& Management 40, 191-204.

Leiponen, A. and Drejer, I., 2007. What exactly are technological regimes?: Intra-industry heterogeneity in the organization of innovation activities. Research policy 36, 1221-1238.

Lenderink, B., Halman, J.I.M., Boes, H. and Voordijk, H., 2020. A method to encourage and assess innovations in public tenders for infrastructure and construction projects. Construction innovation.

Lennartsson, M. and Björnfot, A., 2010. Step-by-step modularity: A roadmap for building service development. Lean Construction Journal 2010, 17-29.

Lervik, J.E. and Lunnan, R., 2004. Contrasting perspectives on the diffusion of management knowledge - performance management in a norwegian multinational. Management Learning 35, 287-302.

Lessing, J., Stehn, L. and Ekholm, A., 2005. Industrialised housing: Definition and categorization of the concept, Annual conference of the International Group for Lean Construction: 18/07/2005$21 / 07 / 2005$. International group for lean construction, pp. 471-480.

Lessing, J., Stehn, L. and Ekholm, A., 2015. Industrialised house-building-development and conceptual orientation of the field. Construction innovation 15, 378-399.

Levander, E., Engström, S., Sardén, Y. and Stehn, L., 2011. Construction clients' ability to manage uncertainty and equivocality. Construction Management and Economics 29, 753-764.

Levy, Y. and Ellis, T.J., 2006. A systems approach to conduct an effective literature review in support of information systems research. Informing Science: International Journal of an Emerging Transdiscipline 9, 181-212.

Lewis, W., Agarwal, R. and Sambamurthy, V., 2003. Sources of influence on beliefs about information technology use: An empirical study of knowledge workers. Mis Quarterly 27, 657-678.

$\mathrm{Li}, \mathrm{X} ., 2009$. Preemptive learning, competency traps, and information technology adoption: A real options analysis. leee Transactions on Engineering Management 56, 650-662.

Liang, H., Saraf, N., Hu, Q. and Xue, Y., 2007. Assimilation of enterprise systems: The effect of institutional pressures and the mediating role of top management. MIS quarterly, 59-87.

Lin, H.-F., Su, J.-Q. and Higgins, A., 2016. How dynamic capabilities affect adoption of management innovations. Journal of Business Research $69,862-876$. 
Lind, H., 2011. Industrialized house building in sweden: A stress test approach for understanding success and failure, 6th Nordic Conference on Construction Economics and Organisation-Shaping the Construction/Society Nexus, p. 79.

Lindgren, J., 2016. Diffusing systemic innovations: Influencing factors, approaches and further research. Architectural Engineering and Design Management 12, 19-28.

Lindgren, J., 2018. Diffusion of systemic innovations in the construction sector. Halmstad University Press.

Lindgren, J. and Emmitt, S., 2017. Diffusion of a systemic innovation: A longitudinal case study of a swedish multi-storey timber housebuilding system. Construction innovation 17, 25-44.

Lissoni, F., 2005. The reaper and the scanner: Indivisibility-led incremental innovations and the adoption of new technologies. Cambridge Journal of Economics 29, 359-379.

Liu, D., Lu, W. and Niu, Y., 2018. Extended technology-acceptance model to make smart construction systems successful. Journal of Construction Engineering and Management 144, 04018035.

London, K. and Kenley, R., 2001. Industrial organisation of supply chains in a small isolated construction market. Construction management and economics 19, 777-788.

Love, E.G. and Cebon, P., 2008. Meanings on multiple levels: The influence of field-level and organizational-level meaning systems on diffusion. Journal of Management Studies 45, 239-267.

Lovell, H. and Smith, S.J., 2010. Agencement in housing markets: The case of the uk construction industry. Geoforum 41, 457-468.

Lu, W., Chen, K., Xue, F. and Pan, W., 2018. Searching for an optimal level of prefabrication in construction: An analytical framework. Journal of Cleaner Production 201, 236-245.

Lutzenhiser, L., 1994. Innovation and organizational networks barriers to energy efficiency in the us housing industry. Energy Policy 22, 867-876.

Lyle, G., 2015. Understanding the nested, multiscale, spatial and hierarchical nature of future climate change adaptation decision making in agricultural regions: A narrative literature review. Journal of Rural Studies 37, 38-49.

Mahajan, V., Muller, E. and Bass, F.M., 1990. New product diffusion models in marketing: A review and directions for research. The Journal of Marketing, pp. 1-26.

Mahajan, V., Muller, E. and Wind, Y., 2000. New-product diffusion models. Springer.

Manchanda, P., Xie, Y. and Youn, N., 2008. The role of targeted communication and contagion in product adoption. Marketing Science 27, 961-976.

Mansfield, E., 1961. Technical change and the rate of imitation. Econometrica: Journal of the Econometric Society, pp. 741-766.

Mansfield, E., 1968. Industrial research and technological innovation; an econometric analysis.

Marenya, P.P. and Barrett, C.B., 2007. Household-level determinants of adoption of improved natural resources management practices among smallholder farmers in western kenya. Food Policy 32, pp. 515-536.
Marshall, G.R., 2009. Polycentricity, reciprocity, and farmer adoption of conservation practices under community-based governance. Ecological Economics 68, 1507-1520.

Marzi, G., Dabić, M., Daim, T. and Garces, E., 2017. Product and process innovation in manufacturing firms: A 30-year bibliometric analysis. Scientometrics 113, 673-704

Massini, S., Lewin, A.Y. and Greve, H.R., 2005. Innovators and imitators: Organizational reference groups and adoption of organizational routines. Research Policy 34, 1550-1569.

Matinaro, V. and Liu, Y., 2015. Virtual design and construction: Innovation process and diffusion in finnish construction business. International Journal of Innovation and Learning 18, 133-150.

McCabe, A., Pojani, D. and van Groenou, A.B., 2018. The application of renewable energy to social housing: A systematic review. Energy Policy 114, 549-557.

McCoy, Ahn, Y. and Pearce, A., 2012. Towards establishing diffusion barriers for innovative green building products: A survey of sips builders. College Publishing 7, 153-176.

McCoy, A.P., Koebel, C.T., Sanderford, A.R., Franck, C.T. and Keefe, M.J., 2015. Adoption of high-performance housing technologies among us homebuilding firms, 2000 through 2010. Cityscape 17, 167-188.

Meade, N. and Islam, T., 2006. Modelling and forecasting the diffusion of innovation-a 25-year review. International Journal of forecasting 22, 519-545.

Meyer, A.D. and Goes, J.B., 1988. Organizational assimilation of innovations: A multilevel contextual analysis. Academy of Management Journal 31, pp. 897-923.

Meyer, J.W. and Rowan, B., 1977. Institutionalized organizations: Formal structure as myth and ceremony. American Journal of Sociology, pp. 340-363.

Meyer, M.H., Tertzakian, P. and Utterback, J.M., 1997. Metrics for managing research and development in the context of the product family. Management science 43, pp. 88-111.

Midgley, D.F. and Dowling, G.R., 1978. Innovativeness: The concept and its measurement. Journal of consumer research 4, pp. 229-242.

Mikkola, J.H., 2006. Capturing the degree of modularity embedded in product architectures. Journal of Product Innovation Management 23, 128-146.

Miles, M.B. and Huberman, A.M., 1994. Qualitative data analysis: An expanded sourcebook. Sage Publications, Incorporated.

Miles, M.B., Huberman, A.M. and Saldaña, J., 2014. Qualitative data analysis: A methods sourcebook. 3rd. Thousand Oaks, CA: Sage.

Milgrom, P. and Roberts, J., 1990a. The economics of modern manufacturing: Technology, strategy, and organization. The American economic review, $511-528$

Milgrom, P. and Roberts, J., 1990b. Rationalizability, learning, and equilibrium in games with strategic complementarities. Econometrica: Journal of the Econometric Society, 1255-1277.

Milgrom, P. and Roberts, J., 1995. Complementarities and fit strategy, structure, and organizational change in manufacturing. Journal of accounting and economics 19, 179-208. 
Milliman, S.R. and Prince, R., 1989. Firm incentives to promote technological change in pollution control. Journal of Environmental Economics and Management 17, 247-265.

Miozzo, M. and Dewick, P., 2002. Building competitive advantage: Innovation and corporate governance in european construction. Research policy 31, 989-1008

Miozzo, M. and Dewick, P., 2004. Networks and innovation in european construction: Benefits from inter-organisational cooperation in a fragmented industry. International Journal of Technology Management 27, 68-92.

Mitropoulos, P. and Tatum, C.B., 2000. Forces driving adoption of new information technologies. Journal of Construction Engineering and management $126,340-348$.

Mlecnik, E., 2010. Adoption of highly energy-efficient renovation concepts. open house international 35.

Mlecnik, E., 2016. Activating the adoption of innovation: Lessons from a passive house network. Built Environment Project and Asset Management 6, 205-217.

Mlecnik, E., Visscher, H. and Van Hal, A., 2010. Barriers and opportunities for labels for highly energy-efficient houses. Energy Policy 38, 4592-4603.

Moglia, M., Cook, S. and McGregor, J., 2017. A review of agent-based modelling of technology diffusion with special reference to residential energy efficiency. Sustainable Cities and Society 31, 173-182.

Molinillo, S. and Japutra, A., 2017. Organizational adoption of digital information and technology: A theoretical review. The Bottom Line 30, 33-46.

Molla, A. and Licker, P.S., 2005a. Ecommerce adoption in developing countries: A model and instrument. Information \& Management 42, 877-899.

Molla, A. and Licker, P.S., 2005b. Perceived e-readiness factors in e-commerce adoption: An empirical investigation in a developing country. International Journal of Electronic Commerce 10, 83-110.

Montazemi, A.R. and Qahri-Saremi, H., 2015. Factors affecting adoption of online banking: A meta-analytic structural equation modeling study. Information \& Management 52, 210-226.

Moore, G.C. and Benbasat, I., 1991. Development of an instrument to measure the perceptions of adopting an information technology innovation. Information Systems Research 2, pp. 192-222.

Mueller, L. and Berker, T., 2013. Passive house at the crossroads: The past and the present of a voluntary standard that managed to bridge the energy efficiency gap. Energy Policy 60, 586-593.

Muffatto, M. and Roveda, M., 2000. Developing product platforms:: Analysis of the development process. Technovation 20, 617-630.

Mukherjee, A. and Muga, H., 2010. An integrative framework for studying sustainable practices and its adoption in the aec industry: A case study. Journal of Engineering and Technology Management 27, 197-214.

Murphy, M., Heaney, G. and Perera, S., 2011. A methodology for evaluating construction innovation constraints through project stakeholder competencies and fmea. Construction innovation 11, 416-440.
Murphy, M.E., Perera, S. and Heaney, G., 2015. Innovation management model: A tool for sustained implementation of product innovation into construction projects. Construction Management and Economics 33, 209-232.

Mustonen-Ollila, E. and Lyytinen, K., 2003. Why organizations adopt information system process innovations: A longitudinal study using diffusion of innovation theory. Information Systems Journal $13,275-297$.

Muyingo, H., 2015. Organizational challenges in the adoption of building applied photovoltaics in the swedish tenant-owner housing sector. Sustainability 7, 3637-3664.

Mwirigi, J., Balana, B.B., Mugisha, J., Walekhwa, P., Melamu, R., Nakami, S. and Makenzi, P., 2014. Socio-economic hurdles to widespread adoption of small-scale biogas digesters in sub-saharan africa: A review. biomass and bioenergy 70, 17-25.

Nahmens, I. and Reichel, C., 2013. Adoption of high performance building systems in hot-humid climates-lessons learned. Construction innovation 13, 186-201.

Naim, M. and Barlow, J., 2003. An innovative supply chain strategy for customized housing. Construction Management and Economics 21, 593-602.

Nair, G., Gustavsson, L. and Mahapatra, K., 2010a. Factors influencing energy efficiency investments in existing swedish residential buildings. Energy Policy 38, 2956-2963.

Nair, G., Gustavsson, L. and Mahapatra, K., $2010 \mathrm{~b}$. Owners perception on the adoption of building envelope energy efficiency measures in swedish detached houses. Applied Energy 87, 2411-2419.

Nair, G., Mahapatra, K. and Gustavsson, L., 2012. Implementation of energy-efficient windows in swedish single-family houses. Applied Energy 89, 329-338.

Naney, D., Goser, C. and Azambuja, M., 2012. Accelerating the adoption of lean thinking in the construction industry. Proceedings for the 20th International Group for Lean Construction, 291-300.

NAO, 2005. Using modern methods of construction to build homes more quickly and efficiently. Office, N.A., London, UK.

Nejad, M.G., Sherrell, D.L. and Babakus, E., 2014. Influentials and influence mechanisms in new product diffusion: An integrative review. Journal of Marketing Theory and Practice 22, 185-208.

Nelson, R.R., Science, N.Y.U.G.S.o.B.A.C.f. and Policy, T., 1982. Government and technical progress: A cross-industry analysis. Pergamon Press.

Nelson, R.R. and Winter, S.G., 1977. In search of useful theory of innovation. Research policy 6, 36-76.

Newman, M.E. and Girvan, M., 2004. Finding and evaluating community structure in networks. Physical review E 69, pp. 026113.

NHBC, F., 2016. Modern methods of construction, views from the industry. IHS BRE Press.

Njuguna, D.G., 1997. Diffusion of bio-climatic building design techniques in kenya: Impediments and opportunities. Habitat International 21, 347-359.

Norton, J.A. and Bass, F.M., 1987. A diffusion theory model of adoption and substitution for successive generations of high-technology products. Management science 33, pp. 1069-1086. 
Novins, D.K., Green, A.E., Legha, R.K. and Aarons, G.A., 2013. Dissemination and implementation of evidence-based practices for child and adolescent mental health: A systematic review. Journal of the American Academy of Child \& Adolescent Psychiatry 52, 1009-1025. e1018.

'Mahoney, J., 2007. The diffusion of management innovations: The possibilities and limitations of memetics. Journal of Management Studies 44, 1324-1348.

Ojoko, E.O., Osman, M.H., Rahman, A.B.A. and Bakhary, N., 2018. Evaluating the critical success factors of industrialised building system implementation in nigeria: The stakeholders' perception. International Journal of Built Environment and Sustainability 5.

Olsthoorn, M., Schleich, J. and Faure, C., 2019. Exploring the diffusion of low-energy houses: An empirical study in the european union. Energy Policy 129, 1382-1393.

Orbach, Y. and Fruchter, G.E., 2011. Forecasting sales and product evolution: The case of the hybrid/electric car. Technological Forecasting and Social Change 78, 1210-1226.

Ortiz, W., Terrapon-Pfaff, J. and Dienst, C., 2017. Understanding the diffusion of domestic biogas technologies. Systematic conceptualisation of existing evidence from developing and emerging countries. Renewable and Sustainable Energy Reviews 74, 1287-1299.

Oster, S.M. and Quigley, J.M., 1977. Regulatory barriers to the diffusion of innovation: Some evidence from building codes. The Bell Journal of Economics, 361-377.

Owen, A., Mitchell, G. and Gouldson, A., 2014. Unseen influence-the role of low carbon retrofit advisers and installers in the adoption and use of domestic energy technology. Energy Policy 73, 169-179.

Ozaki, R., 2003. Customer?focused approaches to innovation in housebuilding. Construction Management and Economics 21, 557-564.

Ozorhon, B., Abbott, C. and Aouad, G., 2013. Integration and leadership as enablers of innovation in construction: Case study. Journal of Management in Engineering 30, 256-263.

Pae, J.H. and Lehmann, D.R., 2003. Multigeneration innovation diffusion: The impact of intergeneration time. Journal of the Academy of Marketing Science 31, 36-45.

Pan, W. and Cooper, M., 2011. Decision criteria for selecting air source heat pump technology in uk low carbon housing. Technology Analysis \& Strategic Management 23, 623-637.

Pan, W., Gibb, A.G. and Dainty, A.R., 2007. Perspectives of uk housebuilders on the use of offsite modern methods of construction. Construction management and Economics 25, 183-194.

Pan, W., Gibb, A.G. and Dainty, A.R., 2008. Leading uk housebuilders' utilization of offsite construction methods. Building Research \& Information 36, 56-67.
Parsons, D., Goodhew, S., Fewkes, A. and De Wilde, P., 2010. The perceived barriers to the inclusion of rainwater harvesting systems by uk house building companies. Urban Water Journal 7, 257-265.

Patel, P.C. and Jayaram, J., 2014. The antecedents and consequences of product variety in new ventures: An empirical study. Journal of Operations Management 32, 34-50.

Patterson, K.A., Grimm, C.M. and Corsi, T.M., 2003. Adopting new technologies for supply chain management. Transportation Research Part E-Logistics and Transportation Review 39, 95-121.

Pavitt, K., 1984. Sectoral patterns of technical change: Towards a taxonomy and a theory. Research policy 13, 343-373.

Peres, R., Muller, E. and Mahajan, V., 2010. Innovation diffusion and new product growth models: $A$ critical review and research directions. International Journal of Research in Marketing 27, 91-106.

Pero, M., Stößlein, M. and Cigolini, R., 2015. Linking product modularity to supply chain integration in the construction and shipbuilding industries. International Journal of Production Economics $170,602-615$

Pfeffer, J. and Salancik, G.R., 1978. The external control of organizations: A resource dependence perspective. Harper \& Row.

Pinkse, J. and Dommisse, M., 2009. Overcoming barriers to sustainability: An explanation of residential builders' reluctance to adopt clean technologies. Business Strategy and the Environment 18, 515-527.

Pittini, A., Koessl, G., Dijol, J., Lakatos, E. and Ghekiere, L., 2017. The state of housing in the eu 2017. Brussel.

Popay, J., Roberts, H., Sowden, A., Petticrew, M., Arai, L., Rodgers, M., Britten, N., Roen, K. and Duffy, S., 2006. Guidance on the conduct of narrative synthesis in systematic reviews. A product from the ESRC methods programme Version 1, b92.

Porter, M.E., 1980. Competitive strategy: Techniques for analyzing industries and competitors. New York: Free Press.

Prasad, A. and Mahajan, V., 2003. How many pirates should a software firm tolerate? An analysis of piracy protection on the diffusion of software. International Journal of Research in Marketing 20, 337-353.

Premkumar, G. and Ramamurthy, K., 1995. The role of interorganizational and organizational factors on the decision mode for adoption of interorganizational systems. Decision sciences 26, 303-336.

Premkumar, G., Ramamurthy, K. and Nilakanta, S., 1994. Implementation of electronic data interchange: An innovation diffusion perspective. Journal of Management Information Systems 11, 157-186

Premkumar, G. and Roberts, M., 1999. Adoption of new information technologies in rural small businesses. Omega 27, 467-484.

Pries, F. and Janszen, F., 1995. Innovation in the construction industry: The dominant role of the environment. Construction Management and Economics 13, 43-51. 
Radu, L.-D., 2016. Determinants of green ict adoption in organizations: A theoretical perspective. Sustainability 8, 731.

Rahbauer, S., Menapace, L., Menrad, K. and Decker, T., 2016. Adoption of green electricity by small-and medium-sized enterprises in germany. Renewable and Sustainable Energy Reviews 59, 1185-1194.

Rahman, M.M., 2013. Barriers of implementing modern methods of construction. Journal of Management in Engineering 30, 69-77.

Rahmandad, H. and Sterman, J., 2008. Heterogeneity and network structure in the dynamics of diffusion: Comparing agent-based and differential equation models. Management Science 54, 998-1014.

Ramiller, N.C. and Swanson, E.B., 2003. Organizing visions for information technology and the information systems executive response. Journal of Management Information Systems 20, 13-50.

Ramli, N.A., Abdullah, C.S., Nawi, M.N.M., Zalazilah, M.H., Mydin, M.A.O. and Hamid, Z.A., 2019. A model of load-bearing masonry (lbm) technology adoption: Empirical study in the malysia country. Malaysian Construction Research Journal, 204.

Randhawa, K., Wilden, R. and Hohberger, J., 2016. A bibliometric review of open innovation: Setting a research agenda. Journal of Product Innovation Management.

Reay, T., Chreim, S., Golden-Biddle, K., Goodrick, E., Williams, B.E., Casebeer, A., Pablo, A. and Hinings, C., 2013. Transforming new ideas into practice: An activity based perspective on the institutionalization of practices. Journal of Management Studies 50, 963-990.

Reichstein, T., Salter, A. and Gann, D., 2005. Last among equals: A comparison of innovation in construction, services and manufacturing in the uk. Construction Management and Economics 23, 631-644.

Reichstein, T., Salter, A. and Gann, D., 2008. Break on through: Sources and determinants of product and process innovation among uk construction firms. Industry and Innovation 15, 601-625.

Reinganum, J.F., 1981. On the diffusion of new technology: A game theoretic approach. The Review of Economic Studies 48, 395-405.

Requate, T., 2005a. Dynamic incentives by environmental policy instruments - a survey. Ecological Economics 54, 175-195.

Requate, T., 2005b. Timing and commitment of environmental policy, adoption of new technology, and repercussions on r\&d. Environmental \& Resource Economics 31, 175-199.

Requate, T. and Unold, W., 2003. Environmental policy incentives to adopt advanced abatement technology: Will the true ranking please stand up? European Economic Review 47, 125-146.

Rezvani, Z., Jansson, J. and Bodin, J., 2015. Advances in consumer electric vehicle adoption research: A review and research agenda. Transportation research part D: transport and environment 34 122-136.

Riala, M. and Ilola, L., 2014. Multi-storey timber construction and bioeconomy-barriers and opportunities. Scandinavian journal of forest research 29, 367-377.
Rijksoverheid, 2019. Klimaatakkoord (climate agreement), Rijksoverheid The Hague

Rijskoverheid, 2019. Klimaatakkoord hoofdstuk gebouwde omgeving (climate agreement section built environment), Rijksoverheid The Hague

Rip, A. and Kemp, R., 1998. Technological change. In: Rayner s., malone el (editors). Battelle Press.

Roders, M. and Straub, A., 2015. Assessment of the likelihood of implementation strategies for climate change adaptation measures in dutch social housing. Building and Environment 83, 168-176.

Roehrich, G., 2004. Consumer innovativeness: Concepts and measurements. Journal of Business Research 57, 671-677.

Rogers, E.M., 1962. Diffusion of innovations. Free Press of Glencoe.

Rogers, E.M., 1983. Diffusion of innovations, 3th ed. New York.

Rogers, E.M., 1995. Diffusion of innovations, 4th ed. New York.

Rogers, E.M., 2003. Diffusion of innovations, 5th ed New York: Free Press.

Rosales-Carreón, J. and García-Díaz, C., 2015. Exploring transitions towards sustainable construction: The case of near-zero energy buildings in the netherlands. Journal of Artificial Societies and Social Simulation 18, 10.

Ross, R., Cartwright, P. and Novakovic, O., 2006. A guide to modern methods of construction. Bre press.

Saloner, G. and Shepard, A., 1992. Adoption of technologies with network effects: An empirical examination of the adoption of automated teller machines.

Salvador, F., 2007. Toward a product system modularity construct: Literature review and reconceptualization. leee Transactions on Engineering Management 54, 219-240.

Salvador, F., Forza, C. and Rungtusanatham, M., 2002. How to mass customize: Product architectures, sourcing configurations. Business Horizons 45, 61-69.

Salvador, F., Rungtusanatham, M. and Forza, C., 2004. Supply-chain configurations for mass customization. Production Planning \& Control 15 381-397.

Samuelson, W. and Zeckhauser, R., 1988. Status quo bias in decision making. Journal of risk and uncertainty 1, 7-59.

Sanakulov, N. and Karjaluoto, H., 2015. Consumer adoption of mobile technologies: A literature review. International Journal of Mobile Communications 13, 244-275.

Sanchez, R. and Mahoney, J.T., 1996. Modularity, flexibility and knowledge management in product and organization design. Strategic Management Journal 17, 63-76.

Sanderford, A.R., Keefe, M.J., Koebel, C.T. and McCoy, A.P., 2015. Factors influencing us homebuilders' adoption of green homebuilding products. Journal of Sustainable Real Estate 7, 60-82.

Sanderford, A.R., McCoy, A.P. and Keefe, M.J., 2018. Adoption of energy star certifications: Theory and evidence compared. Building Research \& Information 46, 207-219. 
Sanderson, S. and Uzumeri, M., 1995. Managing product families: The case of the sony walkman. Research policy 24, 761-782.

Sasatani, D., Bowers, T., Ganguly, I. and Eastin, I.L. 2015. Adoption of casbee by japanese house builders. Journal of Green Building 10, 186-201.

Schivardi, F. and Schneider, M., 2008. Strategic experimentation and disruptive technological change. Review of Economic Dynamics 11, 386412 .

Schlereth, C., Barrot, C., Skiera, B. and Takac, C., 2013. Optimal product-sampling strategies in social networks: How many and whom to target? International Journal of Electronic Commerce 18, 45-72.

Schraven, D.F., Hartmann, A. and Dewulf, G.P., 2015 Research orientations towards the 'management'of infrastructure assets: An intellectual structure approach. Structure and infrastructure engineering 11, 73-96.

Schumpeter, J.A., 1934. The theory of economic development: An inquiry into profits, capital, credit, interest, and the business cycle. Transaction publishers.

Schumpeter, J.A., 1942. Socialism, capitalism and democracy. Harper and Brothers.

Schut, E., Crielaard, M. and Mesman, M., 2015. Beleidsverkenning circulaire economie in de bouw: Een perspectief voor de markt en overheid (policy outlook for the circular economy in construction: A perspective for the market and government). Rijkswaterstaat en RIVM, Den Haag, pp. 60.

Seaden, G. and Manseau, A., 2001. Public policy and construction innovation. Building Research \& Information 29, 182-196.

Segerstedt, A. and Olofsson, T., 2010. Supply chains in the construction industry. Supply Chain Management: An International Journal.

Sexton, M., And, P.B. and Aouad, G., 2006. Motivating small construction companies to adopt new technology. Building Research \& Information 34 11-22.

Sexton, M. and Barrett, P., 2005. Performance-based building and innovation: Balancing client and industry needs. Building Research \& Information 33, 142-148.

Shadish, W.R., 1996. Meta-analysis and the exploration of causal mediating processes: A primer of examples, methods, and issues. Psychological Methods 1, 47.

Shafiei, M.W.M., Said, I. and Abidin, N.Z., 2010. Factors influencing firms'readiness towards innovation in house building industry: A multi-dimensional construct. International Journal of Organizational Innovation (Online) 2, 74.

Sheffer, D.A., 2011. Innovation in modular industries implementing energy-efficient innovations in us buildings, Department of Civil and Environmental Engineering. Stanford University, Stanford.

Simon, H.A., 1957. Models of man; social and rational.

Simon, H.A., 1991. Bounded rationality and organizational learning. Organization Science 2, 125-134.

Slater, S.F., Mohr, J.J. and Sengupta, S., 2014. Radical product innovation capability: Literature review, synthesis, and illustrative research propositions. Journal of Product Innovation Management 31, 552-566
Slaughter, E.S., 1998. Models of construction innovation. Journal of Construction Engineering and management 124, 226-231.

Sovacool, B.K. and Hess, D.J., 2017. Ordering theories: Typologies and conceptual frameworks for sociotechnical change. Social studies of science 47, 703-750.

Sriwannawit, P. and Sandström, U., 2015. Large-scale bibliometric review of diffusion research. Scientometrics 102, 1615-1645.

Steinhardt, D., Manley, K., Bildsten, L. and Widen, K., 2019. The structure of emergent prefabricated housing industries: A comparative case study of australia and sweden. Construction management and Economics, 1-19.

Steinhardt, D.A. and Manley, K., 2016. Exploring the beliefs of australian prefabricated house builders. Construction Economics and Building 16, 27-41.

Suarez, F.F., 2005. Network effects revisited: The role of strong ties in technology selection. Academy of Management Journal 48, 710-720.

Suchman, M.C., 1995. Managing legitimacy: Strategic and institutional approaches. Academy of Management Review 20, 571-610.

Sultan, F., Farley, J.U. and Lehmann, D.R., 1990. A meta-analysis of applications of diffusion models. Journal of marketing research, pp. 70-77.

Sundqvist, S., Frank, L. and Puumalainen, K., 2005 The effects of country characteristics, cultural similarity and adoption timing on the diffusion of wireless communications. Journal of Business Research 58, 107-110.

Sunikka, M., 2006. Energy efficiency and low-carbon technologies in urban renewal. Building Research \& Information 34, 521-533.

Sunikka, M., 2017. Policies and regulations for sustainable building: A comparative study of five european countries. Housing and Urban Policy Studies 19.

Swan, J.A. and Newell, S., 1994. Managers' beliefs about factors affecting the adoption of technological innovation. Journal of Managerial Psychology.

Swan, W., Fitton, R., Smith, L., Abbott, C. and Smith, L., 2017. Adoption of sustainable retrofit in uk social housing 2010-2015. International Journal of Building Pathology and Adaptation 35, 456-469.

Swan, W., Ruddock, L. and Smith, L., 2013a. Low carbon retrofit: Attitudes and readiness within the social housing sector. Engineering, Construction and Architectural Management 20, 522-535.

Swan, W., Ruddock, L., Smith, L. and Fitton, R., $2013 \mathrm{~b}$. Adoption of sustainable retrofit in uk social housing. Structural Survey 31, 181-193.

Swanson, E.B. and Ramiller, N.C., 2004. Innovating mindfully with information technology. MIS quarterly, 553-583.

Swart, J., Goedhuys - Van der Linden, M. and Van der Wel, E., 2019. Transformaties op de woningmarkt 2012-2018 (housing market transformations 2012-2018). CBS, Den Haag, pp. 23.

Syal, M., Duah, D., Samuel, S., Mazor, M., Mo, Y. and Cyr, T., 2013. Information framework for intelligent decision support system for home energy retrofits. Journal of Construction Engineering and Management 140, 04013030. 
Tambach, M., Hasselaar, E. and Itard, L., 2010. Assessment of current dutch energy transition policy instruments for the existing housing stock. Energy Policy 38, 981-996.

Tan, D.T., Gong, Y. and Siri, J.G., 2017. The impact of subsidies on the prevalence of climate-sensitive residential buildings in malaysia. Sustainability 9 2300

Tarde, G., 1903. The laws of imitation, trans. EC Parsons. New York: Henry, Holt.

Tatum, C.B., 1987. Process of innovation in construction firm. Journal of Construction Engineering and management 113, 648-663.

Taylor, G.S., Templeton, G.F. and Baker, L.T., 2010. Factors influencing the success of organizational learning implementation: A policy facet perspective. International Journal of Management Reviews 12, 353-364.

Taylor, J. and Levitt, R., 2007. Innovation alignment and project network dynamics: An integrative model for change. Project Management Journal $38,22-35$

Taylor, J.E., 2005. Three perspectives on innovation in interorganizational networks: Systemic innovation, boundary object change, and the alignment of innovations and networks. Stanford University.

Taylor, M.D., 2010. A definition and valuation of the uk offsite construction sector. Construction Management and Economics 28, pp. 885-896.

Taylor, M.R., Rubin, E.S. and Hounshell, D.A., 2005. Control of so2 emissions from power plants: $A$ case of induced technological innovation in the us. Technological Forecasting and Social Change 72, 697-718

Taylor, S. and Todd, P., 1995. Decomposition and crossover effects in the theory of planned behavior: A study of consumer adoption intentions. International Journal of Research in Marketing 12, pp. 137-155

Tayouga, S.J. and Gagné, S.A., 2016. The socio-ecological factors that influence the adoption of green infrastructure. Sustainability 8, 1277.

Teece, D.J., 1986. Profiting from technological innovation: Implications for integration, collaboration, licensing and public policy. Research policy 15, 285-305.

Teece, D.J., Pisano, G. and Shuen, A., 1997. Dynamic capabilities and strategic management. Strategic Management Journal, 509-533.

Teizer, J., Venugopal, M., Teizer, W. and Felkl, J., 2011. Nanotechnology and its impact on construction: Bridging the gap between researchers and industry professionals. Journal of Construction Engineering and management 138, 594-604.

Tellis, G.J., Stremersch, S. and Yin, E., 2003. The international takeoff of new products: The role of economics, culture, and country innovativeness. Marketing science 22, 188-208.

Tennant, S. and Fernie, S., 2014. Theory to practice: A typology of supply chain management in construction. International journal of construction management $14,56-66$

Teo, T.S. and Pok, S.H., 2003. Adoption of wap-enabled mobile phones among internet users. Omega 31, pp. 483-498.
Thillart, C.C.A.M.v.d., 2004. Customised industrialisation in the residential sector - mass customisation modelling as a tool for benchmarking, variation and selection, Department of Real Estate \& Housing; Faculty of Architecture. Delft University of Technology, Delft.

Thong, J.Y.L., 1999. An integrated model of information systems adoption in small businesses. Journal of management information systems 15 , pp. 187-214.

Thuesen, C. and Hvam, L., 2011. Efficient on-site construction: Learning points from a german platform for housing. Construction innovation 11 338-355.

Tidd, J., 2001. Innovation management in context: Environment, organization and performance. International Journal of Management Reviews 3, pp. 169-183.

Tolbert, P.S. and Zucker, L.G., 1983. Institutional sources of change in the formal structure of organizations: The diffusion of civil service reform, 1880-1935. Administrative science quarterly, 22-39.

Toole, T.M., 1998. Uncertainty and home builders' adoption of technological innovations. Journal of Construction Engineering and management 124, 323-332.

Tornatzky, L.G., Fleischer, M. and Chakrabarti, A.K., 1990. Processes of technological innovation. Lexington Books.

Tornatzky, L.G. and Klein, K.J., 1982. Innovation characteristics and innovation adoption-implementation: A meta-analysis of findings. leee Transactions on Engineering Management 29, pp. 28-45.

Tranfield, D.R., Denyer, D. and Smart, P., 2003. Towards a methodology for developing evidence-informed management knowledge by means of systematic review. British Journal of Management 14, pp. 207-222.

Treacy, M. and Wiersema, F., 1993. Customer intimacy and other value disciplines. Harvard Business Review 71, 84-84.

Treacy, M. and Wiersema, F., 1995. How market leaders keep their edge. Fortune 131, 52-57.

Tu, Q., Vonderembse, M.A., Ragu-Nathan, T.S. and Ragu-Nathan, B., 2004. Measuring modularity-based manufacturing practices and their impact on mass customization capability: $A$ customer-driven perspective. Decision Sciences 35, 147-168.

Tushman, M.L. and Anderson, P., 1986. Technological discontinuities and organizational environments. Administrative science quarterly, 439-465.

Ulrich, K., 1995. The role of product architecture in the manufacturing firm. Research policy 24 419-440.

Ulrich, K.T. and Eppinger, S.D., 2012. Product design and development. McGraw-Hill/Irwin.

Utterback, J.M., 1996. Mastering the dynamics of innovation. Harvard Business School Press.

Utterback, J.M. and Abernathy, W.J., 1975. A dynamic model of process and product innovation. Omega 3, 639-656. 
Van Beek, G., Nieuwdorp, C. and Boschman, M., 2016. Megatrends in de bouw. BouwKennis, Rotterdam, pp. 12

Van de Ven, A.H., 1986. Central problems in the management of innovation. Management science 32, 590-607.

van den Berg, M.C., 2019. Managing circular building projects, Faculty of Engineering Technology (ET), Construction Management and Engineering (CME). University of Twente, Enschede.

Van den Bulte, C. and Joshi, Y.V., 2007a. New product diffusion with influentials and imitators. Marketing Science 26, 400-421.

Van den Bulte, C. and Joshi, Y.V., 2007b. New product diffusion with influentials and imitators. Marketing Science 26, pp. 400-421.

Van den Bulte, C. and Lilien, G.L., 2001. Medical innovation revisited: Social contagion versus marketing effort 1 . American Journal of Sociology 106, 1409-1435.

Van den Bulte, C. and Stremersch, S., 2004a. Social contagion and income heterogeneity in new product diffusion: A meta-analytic test. Marketing Science 23, 530-544.

Van den Bulte, C. and Stremersch, S., 2004b. Social contagion and income heterogeneity in new product diffusion: A meta-analytic test. Marketing Science 23, pp. 530-544.

Van den Ende, J. and Kemp, R., 1999. Technological transformations in history: How the computer regime grew out of existing computing regimes. Research policy 28, 833-851.

Van Eck, N.J. and Waltman, L., 2010. Software survey: Vosviewer, a computer program for bibliometric mapping. Scientometrics 84, pp. 523-538.

van Egmond-de Wilde de Ligny, E.L. and Mohammadi, M., 2011. Innovations in domotics: Fulfilling potential or hampered by prevailing technological regime? Construction innovation 11, 470-492.

van Everdingen, Y., Fok, D. and Stremersch, S., 2009 Modeling global spillover of new product takeoff. Journal of Marketing Research 46, 637-652.

Van Everdingen, Y.M., 2003. The effect of national culture on the adoption of innovations. Marketing Letters 14, 217-232.

van Hal, A., 2000. Beyond the demonstration project: The diffusion of environmental innovations in housing, Faculty of Architecture, Delft University of Technology. Uitgeverij ÆEneas BV, Delft.

Van Nunen, H., 2017. \#duurzaamrenoveren: Hoe het wonen stap voor stap duurzaam wordt. Hogeschool Rotterdam Uitgeverij, Rotterdam.

Van Oorschot, J.A.W.H., Halman, J.I.M. and Hofman, E., 2019. The continued adoption of housing systems in the netherlands: A multiple case study. Journal of Construction Engineering, Management \& Innovation 2, 167-190.

Van Oorschot, J.A.W.H., Halman, J.I.M. and Hofman, E., 2020. Getting innovations adopted in the housing sector. Construction innovation.

van Oorschot, J.A.W.H., Hofman, E. and Halman, J.I.M., 2018. A bibliometric review of the innovation adoption literature. Technological Forecasting and Social Change 134, 1-21.
Varabyova, Y., Blankart, C.R., Greer, A.L. and Schreyögg, J., 2017. The determinants of medical technology adoption in different decisional systems: A systematic literature review. Health Policy $121,230-242$.

Veenstra, V.S., Halman, J.I.M. and Voordijk, J.T., 2006. A methodology for developing product platforms in the specific setting of the housebuilding industry. Research in engineering design 17, 157-173.

Venkatesh, V. and Davis, F.D., 2000. A theoretical extension of the technology acceptance model: Four longitudinal field studies. Management science 46, pp. 186-204.

Venkatesh, V., Morris, M.G., Davis, G.B. and Davis, F.D., 2003. User acceptance of information technology: Toward a unified view. Mis Quarterly, pp. 425-478.

Vermeulen, P., Büch, R. and Greenwood, R., 2007. The impact of governmental policies in institutional fields: The case of innovation in the dutch concrete industry. Organization Studies 28, pp. 515-540.

Viana, D., Tommelein, I. and Formoso, C., 2017. Using modularity to reduce complexity of industrialized building systems for mass customization. Energies 10, 1622

Vogel, R. and Güttel, W.H., 2013. The dynamic capability view in strategic management: $A$ bibliometric review. International Journal of Management Reviews 15, pp. 426-446.

Vogler, A., 2016. The house as a product. IOS Press. Voordijk, H., Meijboom, B. and de Haan, J., 2006. Modularity in supply chains: A multiple case study in the construction industry. International Journal of Operations \& Production Management 26, 600-618.

Wang, P., 2010. Chasing the hottest it: Effects of information technology fashion on organizations. Mis Quarterly 34, 63-85.

Wang, Y.-M., Wang, Y.-S. and Yang, Y.-F., 2010. Understanding the determinants of rfid adoption in the manufacturing industry. Technological Forecasting and Social Change 77, 803-815.

Warren-Myers, G. and Heywood, C., 2018. A new demand-supply model to enable sustainability in new australian housing. Sustainability 10, 376

Watt, D., Kayis, B. and Willey, K., 2009. Identifying key factors in the evaluation of tenders for projects and services. International Journal of Project Management 27, 250-260.

Webster, J. and Watson, R.T., 2002. Analyzing the past to prepare for the future: Writing a literature review. Mis Quarterly, xiii-xxiii.

Wejnert, B., 2002. Integrating models of diffusion of innovations: A conceptual framework. Annual review of sociology, 297-326.

Westphal, J.D., Gulati, R. and Shortell, S.M., 1997. Customization or conformity? An institutional and network perspective on the content and consequences of tqm adoption. Administrative science quarterly, 366-394.

White, H.D. and McCain, K.W., 1998a. Visualizing a discipline: An author co-citation analysis of information science, 1972-1995. Journal of the American society for information science 49, 327-355. 
White, H.D. and McCain, K.W., 1998b. Visualizing a discipline: An author co-citation analysis of information science, 1972-1995. Journal of the American society for information science 49 327-355.

Wientjes, B., Buitendijk, G., Meyboom, J., Verhagen, M., Nelissen, E., Reiner, C., Litjens, P., Martinus, A., Van Berkel, B., Talsma, K., Nijhof, A. and Van Wingerden, R., 2017. De bouwagenda: Bouwen an de kwaliteit van leven (the construction agenda: Building on the qualitie of life), Taskforce Bouwagenda, The Hague

Wilhelm, B., 1997. Platform and modular concepts at volkswagen-their effects on the assembly process, Transforming automobile assembly. Springer, pp. 146-156

Williams, M.D., Rana, N.P. and Dwivedi, Y.K., 2015.

The unified theory of acceptance and use of technology (utaut): A literature review. Journal of Enterprise Information Management 28, 443-488.

Winch, G., 1998. Zephyrs of creative destruction: Understanding the management of innovation in construction. Building Research \& Information 26, 268-279.

Wisdom, J.P., Chor, K.H.B., Hoagwood, K.E. and Horwitz, S.M., 2014. Innovation adoption: A review of theories and constructs. Administration and Policy in Mental Health and Mental Health Services Research 41, 480-502.

Wolfe, R.A., 1994. Organizational innovation: Review, critique and suggested research directions*. Journal of management studies 31, 405-431.

Wolfe, S. and Hendriks, E., 2011. Building towards water efficiency: The influence of capacity and capability on innovation adoption in the canadian home-building and resale industries. Journal of Housing and the Built Environment 26, 47-72.

Wolters, M.M., 2002. The business of modularity and the modularity of business, Erasmus Research Institute of Management (ERIM). Erasmus University Rotterdam, Rotterdam.

Wong, G., Greenhalgh, T. and Pawson, R., 2010. Internet-based medical education: A realist review of what works, for whom and in what circumstances. BMC medical education 10, 12 .

Wu, C.-C., 2016. Status quo bias in information system adoption: A meta-analytic review. Online Information Review 40, 998-1017.

Wu, J.H. and Wang, S.C., 2005. What drives mobile commerce? An empirical evaluation of the revised technology acceptance model. Information \& Management 42, 719-729.

Xiahou, X., Yuan, J., Liu, Y., Tang, Y. and Li, Q., 2018. Exploring the driving factors of construction industrialization development in china. International journal of environmental research and public health $15,442$.

Xue, X., Zhang, R., Yang, R. and Dai, J., 2014. Innovation in construction: A critical review and future research. International Journal of Innovation Science 6, 111-126.
Yang, J. and Yang, Z., 2015. Critical factors affecting the implementation of sustainable housing in australia. Journal of Housing and the Built Environment 30, 275-292.

Yeatts, D.E., Auden, D., Cooksey, C. and Chen, C.-F., 2017. A systematic review of strategies for overcoming the barriers to energy-efficient technologies in buildings. Energy Research \& Social Science 32, 76-85.

Yin, R.K., 2003. Case study research: Design and methods. SAGE Publications.

Yin, R.K., 2013. Case study research: Design and methods. Sage publications.

Young, H.P., 2009. Innovation diffusion in heterogeneous populations: Contagion, social influence, and social learning. American Economic Review 99, 1899-1924.

Yusof and Shafiei, M., 2011. Factors affecting housing developers' readiness to adopt innovative systems. Housing Studies 26, 369-384.

Yusof, Shafiei, M.W.M., Said, I. and Abidin, N.Z., 2010. Factors influencing firms' readiness towards innovation in house building industry: A multi-dimensional construct. International Journal of Organizational Innovation, 74.

Yusof, N.A. and Mohd Shafiei, M.W., 2011. Factors affecting housing developers' readiness to adopt innovative systems. Housing Studies 26, 369-384.

Zaltman, G., Duncan, R. and Holbek, J., 1973. Innovations and organizations. Wiley New York.

Zanello, G., Fu, X., Mohnen, P. and Ventresca, M., 2016. The creation and diffusion of innovation in developing countries: A systematic literature review. Journal of Economic Surveys 30, 884-912.

Zeijlemaker, S., Van Heel, P., Nieuwdorp, C. and Boschman, M., 2015. Industrialisatie in de bouw: Van nut naar noodzaak (industrialization in construction: From utility to necessity). ABN-AMRO, Amsterdam, pp. 15.

Zhang, H., Xu, X. and Xiao, J., 2014a. Diffusion of e-government: $A$ literature review and directions for future directions. Government Information Quarterly 31, 631-636.

Zhang, X., Skitmore, M. and Peng, Y., 2014b. Exploring the challenges to industrialized residential building in china. Habitat International 41, 176184.

Zhu, K., Kraemer, K. and Xu, S., 2003. Electronic business adoption by european firms: $A$ cross-country assessment of the facilitators and inhibitors. European Journal of Information Systems 12, 251-268.

Zhu, K. and Kraemer, K.L., 2005. Post-adoption variations in usage and value of e-business by organizations: Cross-country evidence from the retail industry. Information systems research 16 , 61-84.

Zhu, K., Kraemer, K.L., Gurbaxani, V. and Xu, S.X., 2006. Migration to open-standard interorganizational systems: Network effects, switching costs, and path dependency. Mis Quarterly 30, 515-539.

Yang, J.-B., Wang, H.-H., Wang, W.-C. and Ma, S.-M., 2016. Using data envelopment analysis to support best-value contractor selection. Journal of Civil Engineering and Management 22, 199-209. 



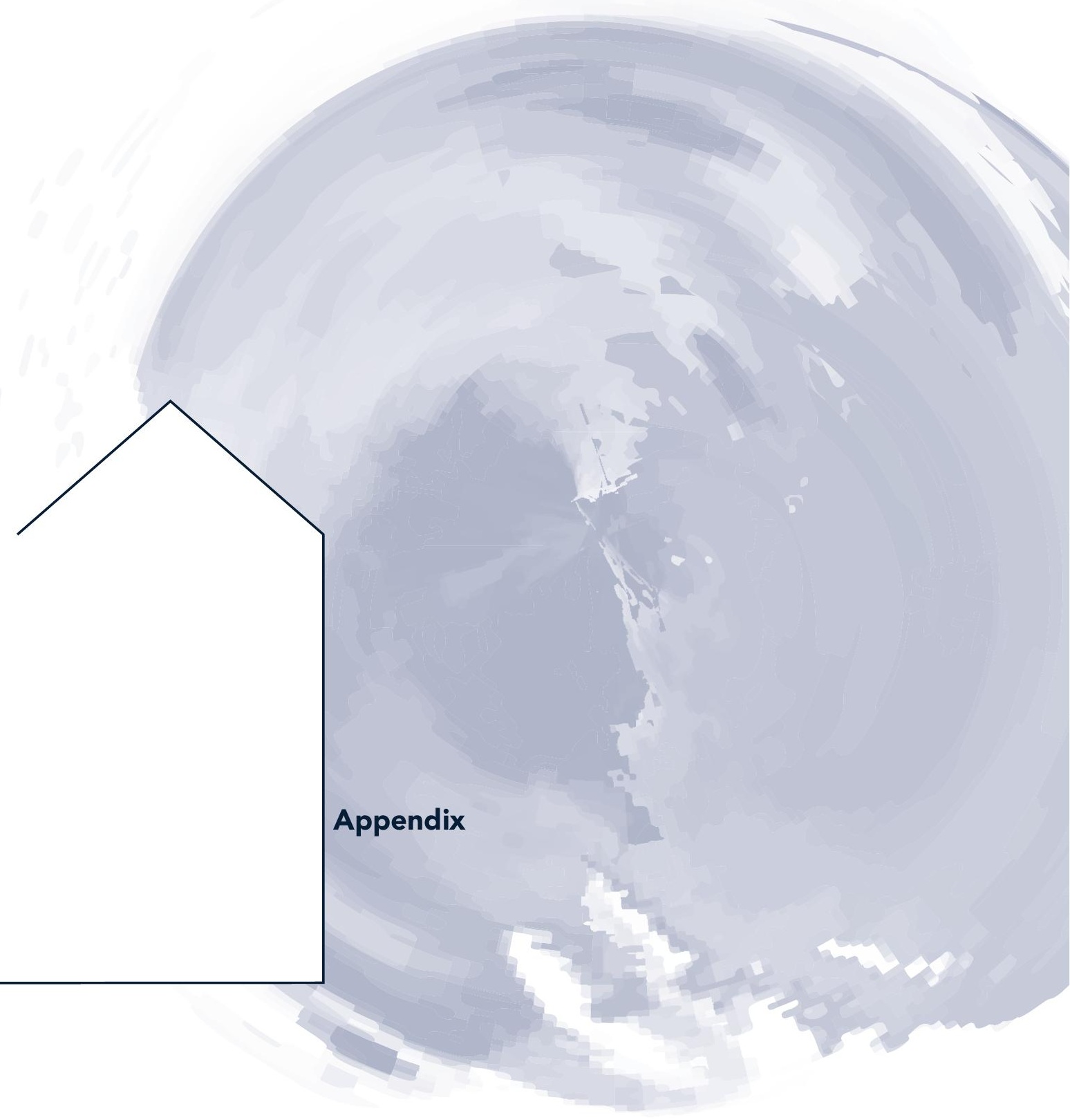


Statement of the Research Problem

Objectives of the Systematic Review

Strategy for Identifying Relevant Studies

Database Selection

Search Terms

Inclusion Criteria

Exclusion Criteria

Quality Audit
Innovation adoption studies are highly segregated and build upon a number of theoretical concepts to explain innovation adoption in the housing projects. It is not clear from the extant literature, how much we know about the adoption determinants, or how a set of determinants might affect adoption in different settings. Managers lack an overview of determinants which might affect the adoption of innovation they intend to introduce.

RQ: Which determinants affect the adoption of innovation in the context of housing projects?

1. To synthesize findings on empirical studies of innovation adoption in housing project, in order to establish what we know.

2. To contribute to the development of an agenda for future research in the field of innovation adoption in housing projects.

Electronic database search of empirical studies of innovation adoption in housing project settings published in peer reviewed scientific journals, complemented by backward and forward reviewing techniques.

Databases selected include: Clarivate Analytics' Web of Science, Elsevier' Scopus and the ARCOM database

To be found in title, abstract, or keywords:

- innovation

- adoption

- construction

- housing (projects)

- Empirical and conceptual studies (qualitative, quantitative and mixed research methodologies)

- Peer-reviewed journal articles

- Only full-text articles

- English language only

- Studies which apply synonyms to describe adoption: 'uptake', '(user) acceptance', diffusion', 'dissemination', 'commercialization', 'implementation' or 'usage'

- Articles that focus on 'implementation' and 'usage' instead of adoption;

- Articles which take social technical regimes shifts, technology transfer and market or industry transitions as focal point of analysis instead of the adoption and/or diffusion of innovation itself. Notwithstanding, papers which include the influence of determinants related to adoption are included in the review;

- Articles which aim to explain the commercialization and marketing of innovation;

- Articles which focal point of analysis is aimed at consumer adoption without taking into consideration the context of the housing industry (for example articles which address the adoption of PV by homeowners from an endogenous perspective without taking into account contextual determinants of the housing industry);

- Feasibility studies which assess the potential merits or progress of diffusion of specific innovations.

- Assessment citations relative to Journal Impact Factor (2017)

- Assessment research findings relative to gap in literature identified 
1. Abdel-Wahab, M., Moore, D. and MacDonald, S., 2011. Exploring the adoption of low carbon technologies by scottish housing associations. International Journal of Low-Carbon Technologies 6, 318-323.

2. Achtnicht, M. and Madlener, R., 2014. Factors influencing german house owners' preferences on energy retrofits. Energy Policy 68, 254-263.

3. Adinyira, E., Kwofie, T. and Quarcoo, F., 2018. Stakeholder requirements for building energy efficiency in mass housing delivery: The house of quality approach. Environment, development and sustainability 20, 1115-1131.

4. Akinboade, O.A., 2012. Drivers of housing technology adoption in south africa. Journal of Geography and Regional Planning 5, 328-338.

5. Ali, M.M., Abas, N.H., Affandi, H.M. and Abas, N.A., 2018. Factors impeding the industrialized building system (ibs) implementation of building construction in malaysia. International Journal of Engineering and Technology (UAE) 7, 2209-2212.

6. Azam Haron, N., Abdul-Rahman, H., Wang, C. and Wood, L.C., 2015. Quality function deployment modelling to enhance industrialised building system adoption in housing projects. Total Quality Management \& Business Excellence 26, 703-718.

7. Baumhof, R., Decker, T., Röder, H. and Menrad, K., 2018. Which factors determine the extent of house owners' energy-related refurbishment projects? A motivation-opportunity-ability approach. Sustainable cities and society $36,33-41$.

8. Beerepoot, M. and Beerepoot, N., 2007. Government regulation as an impetus for innovation: Evidence from energy performance regulation in the dutch residential building sector. Energy Policy 35, 4812-4825.

9. Berardi, U., 2013. Stakeholders' influence on the adoption of energy-saving technologies in italian homes. Energy Policy 60, 520-530.

10. Berry, S., Sharp, A., Hamilton, J. and Killip, G., 2014. Inspiring low-energy retrofits: The influence of 'open home'events. Building Research \& Information $42,422-433$.

11. Blackley, D.M. and Shepard III, E.M., 1996. The diffusion of innovation in home building. Journal of Housing Economics 5, 303-322.

12. Blismas, N. and Wakefield, R., 2009. Drivers, constraints and the future of offsite manufacture in australia. Construction innovation 9, 72-83.
13. Boser, R.A. and El-Gafy, M., 2011. Accelerating waste minimization in residential construction: $A$ source separation case study. International Journal of Construction Education and Research 7, 58-70.

14. Bossink, B., 2018. The influence of knowledge flow on sustainable innovation in a project-based industry: From demonstration to limited adoption of eco-innovations. Journal of cleaner production 193, 249-262.

15. Bowers, T., Ganguly, I. and Eastin, I., 2014. Eco-labeled wood products in the us residential construction industry: Architects' awareness and usage of certified wood and green building programs. The Forestry Chronicle 90, 605-613.

16. Boyd, N., Khalfan, M.M. and Maqsood, T., 2012. Off-site construction of apartment buildings. Journal of Architectural Engineering 19, 51-57.

17. Brown, Swan, W. and Chahal, S., 2014. Retrofitting social housing: Reflections by tenants on adopting and living with retrofit technology. Energy Efficiency 7 641-653.

18. Chen, Q., Kinzel, G., Zimmerman, A., Potter, S. and Lichtensteiger, M., 2011. Barriers and impediments to a holistic approach to promoting super-energy-efficient (see) homes. Journal of Green Building 6, 93-103.

19. Christie, L., Donn, M. and Walton, D., 2011. The 'apparent disconnect'towards the adoption of energy-efficient technologies. Building Research \& Information 39, 450-458.

20. Crabtree, L. and Hes, D., 2009. Sustainability uptake in housing in metropolitan australia: An institutional problem, not a technological one. Housing Studies 24, 203-224

21. Daget, Y.T. and Zhang, H., 2018. Decision-making for evaluation and selection of suitable industrialized housing system. International Journal 15, 167-173.

22. Dewick, P. and Miozzo, M., 2002. Sustainable technologies and the innovation-regulation paradox. Futures 34, 823-840.

23. Duah, D. and Syal, M., 2016. Intelligent decision support system for home energy retrofit adoption. International Journal of Sustainable Built Environment 5, 620-634.

24. Egmond, Jonkers, R. and Kok, G., 2005. A strategy to encourage housing associations to invest in energy conservation. Energy Policy 33, 2374-2384. 
25. Egmond, Jonkers, R. and Kok, G., 2006. A strategy and protocol to increase diffusion of energy related innovations into the mainstream of housing associations. Energy Policy 34, 4042-4049.

26. Elnaas, H., Gidado, K. and Philip, A., 2014. Factors and drivers effecting the decision of using off-site manufacturing (osm) systems in house building industry. Journal of Engineering, Project, and Production Management 4, 51-58.

27. Engström and Hedgren, 2012. Sustaining inertia? Construction clients' decision-making and information-processing approach to industrialized building innovations. Construction innovation 12, 393-413.

28. Fawcett, T., 2014. Exploring the time dimension of low carbon retrofit: Owner-occupied housing. Building Research \& Information 42, 477-488.

29. Femenías, P., Mjörnell, K. and Thuvander, L., 2018. Rethinking deep renovation: The perspective of rental housing in sweden. Journal of cleaner production 195, 1457-1467.

30. Gan, X., Zuo, J., Ye, K., Skitmore, M. and Xiong, B., 2015. Why sustainable construction? Why not? An owner's perspective. Habitat International 47, 61-68.

31. Ganguly, I., Koebel, C.T. and Cantrell, R.A., 2010. A categorical modeling approach to analyzing new product adoption and usage in the context of the building-materials industry. Technological forecasting and social change $77,662-677$.

32. Graham, E. and Warren-Myers, G., 2019. Investigating the efficacy of a professional education program in promoting sustainable residential construction practices in australia. Journal of cleaner production $210,1238-1248$.

33. Haines, V. and Mitchell, V., 2014. A persona-based approach to domestic energy retrofit. Building Research \& Information 42, 462-476.

34. Hauge, Å.L., Thomsen, J. and Löfström, E., 2013. How to get residents/owners in housing cooperatives to agree on sustainable renovation. Energy Efficiency 6, 315-328.

35. Hedgren, E. and Stehn, L., 2014. The impact of clients' decision-making on their adoption of industrialized building. Construction management and Economics 32, 126-145.

36. Hoicka, C.E. and Parker, P., 2018. Assessing the adoption of the house as a system approach to residential energy efficiency programs. Energy Efficiency 11, 295-313.

37. Hoppe, T., 2012. Adoption of innovative energy systems in social housing: Lessons from eight large-scale renovation projects in the netherlands. Energy Policy 51, 791-801.
38. Im, J., Seo, Y., Cetin, K.S. and Singh, J., 2017. Energy efficiency in us residential rental housing: Adoption rates and impact on rent. Applied Energy 205, 1021-1033.

39. Kereri, J.O. and Adamtey, S., 2019. Rfid use in residential/commercial construction industry. Journal of Engineering, Design and Technology.

40. Koebel, C.T., 2008. Innovation in homebuilding and the future of housing. Journal of the American Planning Association 74, 45-58.

41. Koebel, C.T., McCoy, A.P., Sanderford, A.R., Franck, C.T. and Keefe, M.J., 2015. Diffusion of green building technologies in new housing construction. Energy and Buildings 97, 175-185.

42. Lees, T. and Sexton, M., 2014. An evolutionary innovation perspective on the selection of low and zero-carbon technologies in new housing. Building Research \& Information 42, 276-287.

43. Levander, E., Engström, S., Sardén, Y. and Stehn, L., 2011. Construction clients' ability to manage uncertainty and equivocality. Construction management and Economics 29, 753-764.

44. Lindgren, J. and Emmitt, S., 2017. Diffusion of a systemic innovation: A longitudinal case study of a swedish multi-storey timber housebuilding system. Construction innovation 17, 25-44.

45. Liu, D., Lu, W. and Niu, Y., 2018. Extended technology-acceptance model to make smart construction systems successful. Journal of Construction Engineering and Management 144, 04018035.

46. McCabe, A., Pojani, D. and van Groenou, A.B., 2018. The application of renewable energy to social housing: A systematic review. Energy Policy 114, 549-557.

47. McCoy, Ahn, Y. and Pearce, A., 2012. Towards establishing diffusion barriers for innovative green building products: A survey of sips builders. College Publishing 7, 153-176.

48. McCoy, A.P., Koebel, C.T., Sanderford, A.R., Franck, C.T. and Keefe, M.J., 2015. Adoption of high-performance housing technologies among us homebuilding firms, 2000 through 2010. Cityscape $17,167-188$

49. Mlecnik, E., 2010. Adoption of highly energy-efficient renovation concepts. open house international 35.

50. Mlecnik, E., 2016. Activating the adoption of innovation: Lessons from a passive house network. Built Environment Project and Asset Management 6, 205-217.

51. Mlecnik, E., Visscher, H. and Van Hal, A., 2010. Barriers and opportunities for labels for highly energy-efficient houses. Energy Policy 38, 4592-4603. 
52. Mueller, L. and Berker, T., 2013. Passive house at the crossroads: The past and the present of a voluntary standard that managed to bridge the energy efficiency gap. Energy Policy 60, 586-593.

53. Muyingo, H., 2015. Organizational challenges in the adoption of building applied photovoltaics in the swedish tenant-owner housing sector. Sustainability $7,3637-3664$

54. Nahmens, I. and Reichel, C., 2013. Adoption of high performance building systems in hot-humid climates-lessons learned. Construction innovation 13, 186-201.

55. Nair, G., Gustavsson, L. and Mahapatra, K., 2010a. Factors influencing energy efficiency investments in existing swedish residential buildings. Energy Policy $38,2956-2963$

56. Nair, G., Gustavsson, L. and Mahapatra, K., 2010b. Owners perception on the adoption of building envelope energy efficiency measures in swedish detached houses. Applied Energy 87, 2411-2419.

57. Nair, G., Mahapatra, K. and Gustavsson, L., 2012 Implementation of energy-efficient windows in swedish single-family houses. Applied Energy 89, 329-338.

58. Njuguna, D.G., 1997. Diffusion of bio-climatic building design techniques in kenya: Impediments and opportunities. Habitat International 21, 347-359.

59. Ojoko, E.O., Osman, M.H., Rahman, A.B.A. and Bakhary, N., 2018. Evaluating the critical success factors of industrialised building system implementation in nigeria: The stakeholders' perception. International Journal of Built Environment and Sustainability 5.

60. Olsthoorn, M., Schleich, J. and Faure, C., 2019. Exploring the diffusion of low-energy houses: An empirical study in the european union. Energy Policy $129,1382-1393$.

61. Oster, S.M. and Quigley, J.M., 1977. Regulatory barriers to the diffusion of innovation: Some evidence from building codes. The Bell Journal of Economics, 361-377.

62. Owen, A., Mitchell, G. and Gouldson, A., 2014 Unseen influence - the role of low carbon retrofit advisers and installers in the adoption and use of domestic energy technology. Energy Policy 73, 169-179.

63. Ozorhon, B., Abbott, C. and Aouad, G., 2013. Integration and leadership as enablers of innovation in construction: Case study. Journal of Management in Engineering 30, 256-263.

64. Pan, W. and Cooper, M., 2011. Decision criteria for selecting air source heat pump technology in uk low carbon housing. Technology Analysis \& Strategic Management 23, 623-637.
65. Pan, W., Gibb, A.G. and Dainty, A.R., 2007. Perspectives of uk housebuilders on the use of offsite modern methods of construction. Construction management and Economics 25, 183-194.

66. Pan, W., Gibb, A.G. and Dainty, A.R., 2008. Leading uk housebuilders' utilization of offsite construction methods. Building Research \& Information 36, 56-67.

67. Parsons, D., Goodhew, S., Fewkes, A. and De Wilde, P., 2010. The perceived barriers to the inclusion of rainwater harvesting systems by $u k$ house building companies. Urban Water Journal 7, 257-265.

68. Pinkse, J. and Dommisse, M., 2009. Overcoming barriers to sustainability: An explanation of residential builders' reluctance to adopt clean technologies. Business Strategy and the Environment 18, 515-527.

69. Poon, C.S., Yu, A.T. and Ng, L., 2003. Comparison of low-waste building technologies adopted in public and private housing projects in hong kong. Engineering, Construction and Architectural Management 10, 88-98.

70. Ramli, N.A., Abdullah, C.S., Nawi, M.N.M., Zalazilah, M.H., Mydin, M.A.O. and Hamid, Z.A., 2019. A model of load-bearing masonry (lbm) technology adoption: Empirical study in the malysia country. Malaysian Construction Research Journal, 204

71. Riala, M. and Ilola, L., 2014. Multi-storey timber construction and bioeconomy-barriers and opportunities. Scandinavian journal of forest research 29 367-377.

72. Roders, M. and Straub, A., 2015. Assessment of the likelihood of implementation strategies for climate change adaptation measures in dutch social housing. Building and Environment 83, 168-176.

73. Sanderford, A.R., Keefe, M.J., Koebel, C.T. and McCoy, A.P., 2015. Factors influencing us homebuilders' adoption of green homebuilding products. Journal of Sustainable Real Estate 7, 60-82.

74. Sanderford, A.R., McCoy, A.P. and Keefe, M.J., 2018. Adoption of energy star certifications: Theory and evidence compared. Building Research \& Information 46, 207-219.

75. Sasatani, D., Bowers, T., Ganguly, I. and Eastin, I.L., 2015. Adoption of casbee by japanese house builders. Journal of Green Building 10, 186-201.

76. Steinhardt, D., Manley, K., Bildsten, L. and Widen, K., 2019. The structure of emergent prefabricated housing industries: A comparative case study of australia and sweden. Construction management and Economics, 1-19.

77. Steinhardt, D.A. and Manley, K., 2016a. Adoption of prefabricated housing-the role of country context. Sustainable cities and society 22, 126-135. 
78. Steinhardt, D.A. and Manley, K., 2016b. Exploring the beliefs of australian prefabricated house builders. Construction Economics and Building 16, 27-41.

79. Swan, W., Fitton, R., Smith, L., Abbott, C. and Smith, L., 2017. Adoption of sustainable retrofit in $u k$ social housing 2010-2015. International Journal of Building Pathology and Adaptation 35, 456-469.

80. Swan, W., Ruddock, L. and Smith, L., 2013a. Low carbon retrofit: Attitudes and readiness within the social housing sector. Engineering, Construction and Architectural Management 20, 522-535.

81. Swan, W., Ruddock, L., Smith, L. and Fitton, R., 2013b. Adoption of sustainable retrofit in $u k$ social housing. Structural Survey 31, 181-193.

82. Syal, M., Duah, D., Samuel, S., Mazor, M., Mo, Y. and Cyr, T., 2013. Information framework for intelligent decision support system for home energy retrofits. Journal of Construction Engineering and Management 140, 04013030.

83. Tambach, M., Hasselaar, E. and Itard, L., 2010. Assessment of current dutch energy transition policy instruments for the existing housing stock. Energy Policy 38, 981-996.

84. Tan, D.T., Gong, Y. and Siri, J.G., 2017. The impact of subsidies on the prevalence of climate-sensitive residential buildings in malaysia. Sustainability 9, 2300.

85. Toole, T.M., 1998. Uncertainty and home builders' adoption of technological innovations. Journal of Construction Engineering and Management 124, 323-332.

86. van Egmond-de Wilde de Ligny, E.L. and Mohammadi, M., 2011. Innovations in domotics: Fulfilling potential or hampered by prevailing technological regime? Construction innovation 11, 470-492.

87. Warren-Myers, G. and Heywood, C., 2018. A new demand-supply model to enable sustainability in new australian housing. Sustainability 10, 376.

88. Wolfe, S. and Hendriks, E., 2011. Building towards water efficiency: The influence of capacity and capability on innovation adoption in the canadian home-building and resale industries. Journal of Housing and the Built Environment 26, 47-72.

89. Xiahou, X., Yuan, J., Liu, Y., Tang, Y. and Li, Q., 2018. Exploring the driving factors of construction industrialization development in china. International journal of environmental research and public health 15,442 .

90. Yang, J. and Yang, Z., 2015. Critical factors affecting the implementation of sustainable housing in australia. Journal of Housing and the Built Environment 30, 275-292.
91. Yusof and Shafiei, M., 2011. Factors affecting housing developers' readiness to adopt innovative systems. Housing Studies 26, 369-384.

92. Yusof, Shafiei, M.W.M., Said, I. and Abidin, N.Z., 2010. Factors influencing firms' readiness towards innovation in house building industry: A multi-dimensional construct. International Journal of Organizational Innovation, 74.

93. Akmam Syed Zakaria, S., Gajendran, T., Rose, T. and Brewer, G., 2018. Contextual, structural and behavioural factors influencing the adoption of industrialised building systems: A review. Architectural Engineering and Design Management 14, 3-26.

94. Zhang, X., Skitmore, M. and Peng, Y., 2014. Exploring the challenges to industrialized residential building in china. Habitat International 41, 176-184. 




\section{Acknowledgement / Dankbetuiging}

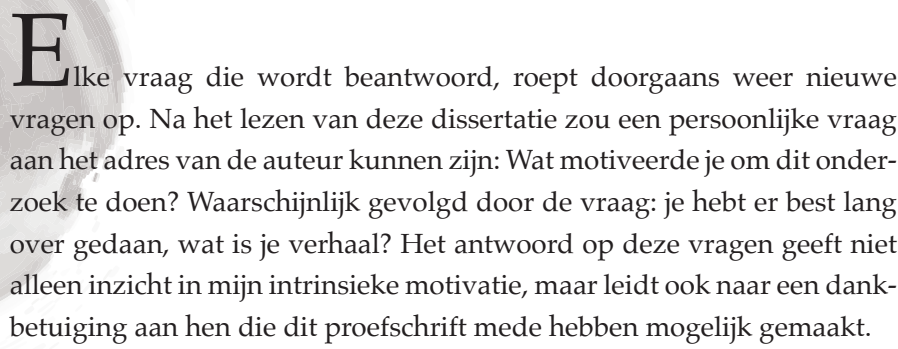

Op basis van eigen ervaring moet een aanstaande promovendus twee competenties - of misschien beter, eigenaardigheden - bezitten om een promotieonderzoek succesvol af te ronden; een niet aflatende fascinatie (of zelfs frustratie) voor een bepaald fenomeen en onvervalste doorzettingsvermogen. Er zullen vast ook nog andere onmisbare competenties kunnen worden verbonden aan het succesvol afronden van een promotieonderzoek, maar deze twee sluiten naadloos aan bij mijn eigen ervaringen.

Mijn fascinatie, en soms ook frustratie, waarom zoveel innovaties niet breed werden of eigenlijk worden geadopteerd en toegepast in de bouw houdt mij al sinds mijn studententijd bezig. Dat motiveerde niet alleen tot het doen van een promotieonderzoek naar dit onderwerp, maar heeft mij al die tijd ook weten te blijven boeien om het vol te houden en te volharden als het (weer) eens tegenzat. Dit brengt mij bij het doorzettingsvermogen dat noodzakelijk is om een promotieonderzoek succesvol af te ronden. Naast volhouden en volharden, heeft doorzettingsvermogen naar mijn mening ook te maken met de absolute wil om jezelf continu te verbeteren en niet te snel tevreden te zijn. En dat laatste ben ik niet. Maar doorzetten en het steeds beter willen doen, kun je niet alleen en daarvoor heb je de steun en hulp nodig van mensen om je heen.
Allereerst wil ik alle respondenten bedanken voor hun bereidheid en medewerking aan de interviews en focusgroepgesprekken. De input van deze respondenten, bestaande uit vertegenwoordigers van zo ongeveer alle disciplines betrokken bij de bouw en renovatie van woningen, was onmisbaar voor het onderzoek. Dank voor alle interessante inzichten en discussies.

Een deel van de respondenten is of was aangesloten bij Stichting Pioneering. Dit kennisnetwerk actief in de regio Twente heeft het onderzoek niet alleen inhoudelijk ondersteund maar ook financieel, waarvoor mijn dank.

Net zoals vele promovendi heb ook ik mijn twijfels gehad tijdens het onderzoek, 'waarom doe ik dit onderzoek en beschik ik wel over de competenties?' Tijdens mijn promotieonderzoek heb ik de overstap gemaakt naar Hogeschool Zuyd om hier achter te komen. Het antwoord op deze vragen heb ik met name gekregen door te participeren in de Europese onderzoeksprojecten MORE-CONNECT, Superlocal en DRIVE-0. Ik wil in het bijzonder Ronald Rovers en Peter op 't Veld bedanken voor de kans die ik heb gekregen in mijn eerste internationale project MORE-CONNECT. Mijn dank gaat ook uit naar de lectoren Nurhan Abujidi en Zeger Vroon van Hogeschool Zuyd die me zijn blijven stimuleren en pushen om het promotieonderzoek af te 
ronden. In het bijzonder wil ik mijn collega Michiel Ritzen bedanken met wie ik een voortrekkersrol heb in het onderzoeksprogramma 'Circular Building Technology', één van de drie programmalijnen binnen het lectoraat Smart Urban Redesign. Bedankt voor je coaching, vertrouwen en vriendschap.

Ook ben ik dank en waardering verschuldigd aan mijn collega's van de academie Built Environment van Hogeschool Zuyd. De bevlogenheid en betrokkenheid van het team voor de ontwikkeling van de bouwkundig ingenieur van de toekomst motiveert ook mij als docent en onderzoeker. Dank aan de teamleiders Joost Rijkers en Maud Hensen voor de wijze waarop ze het BBE-team leiden en de ruimte die ze me geven om mijn werkzaamheden in te vullen.

Tijdens mijn promotieonderzoek ben ik begeleid door Professor Joop Halman en Erwin Hofman; dat hadden zij niet beter kunnen doen. Ik waardeer enorm het geduld en de wijsheid waarmee ze mij door het onderzoek hebben geholpen. Met kritische vragen hebben ze me geholpen om mijn ideeën en redeneringen te ordenen en aan te scherpen. Deze spiegel is voor mij noodzakelijk om onderzoek te doen en mijn ideeën daarover aan te scherpen en te concretiseren. Dank voor alle steun - vooral voor het herhaaldelijk kritisch reflecteren op mijn wetenschappelijke teksten - bij het publiceren van mijn artikelen waarmee ik mijn promotie heb kunnen bewerkstelligen.

Ik wil daarbij ook niet de ondersteuning vanuit de vakgroep Construction Management \& Engineering van de Universiteit Twente onbenoemd laten. In het bijzonder dank aan mijn collega promovendi, een bont internationaal gezelschap, voor de leerzame en gezellige momenten die we hebben mogen delen. Een wijze les die ik heb mogen leren, is dat de aandacht niet primair zou moeten uitgaan naar nationaliteit of cultuur die ons van elkaar doet verschillen, maar naar gedeelde ervaringen die ons verbindt.
Ook een woord van dank aan de "Bouwkunde Boys", mijn studievrienden Jan-Paul Arts, Erik Tillemans en Jeroen van Beek, die interesse zijn blijven tonen in mijn voortgang in het promotieonderzoek. Dank voor de reflectieve gesprekken en ik hoop dat we ondanks onze drukke levens ruimte blijven vinden om onze vriendschap warm te houden.

Maar het allerbelangrijkste bij het succesvol afronden van een intensieve uitdaging zoals een promotieonderzoek is een liefdevol nest en veilige haven om elke keer weer naar terug te keren. Een liefdevolle familie maakt het verschil. Pap, Mam bedankt voor alle goede zorgen en liefde die me hebben gebracht tot wie ik ben vandaag.

Een aantal familieleden heeft ook in meer praktische zin bijgedragen, wat ik niet onbenoemd wil laten. Allereerst mijn dank aan mijn oom Ton van Mol die mij het laatste zetje heeft gegeven om aan het promotieonderzoek te beginnen. Ook een woord van dank aan mijn schoonouders in Twente waar ik menig nachtje heb kunnen logeren om in Enschede aan mijn onderzoek te kunnen werken. Tenslotte wil ik Yvonne van Oorschot-Spiero enorm bedanken bij het ontwerpen en tot stand brengen van deze dissertatie.

Lieve Esther, aan jou ben ik niet alleen dank maar ook excuses verschuldigd. Dank dat je me bent blijven steunen en in me bent blijven geloven. Excuses voor de momenten dat ik er niet was, letterlijk of figuurlijk, omdat het onderzoek me bezighield. Ik hoop dat je een gelijke steun en vertrouwen mag ervaren van mij nu en in de toekomst. Maar het meest dankbaar ben ik voor onze dochters die we samen mogen opvoeden. Lieve dochters, Linde en Annemare, nog te jong om dit bewust mee te maken, ik hoop dat mijn inspanningen mogen bijdragen aan jullie toekomst, in harmonie met mens en planeet. 


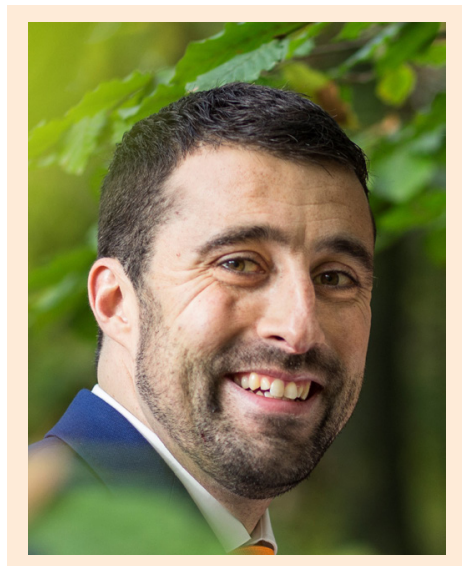

\section{About the author}

John A.W.H. van Oorschot was born in Eindhoven on March 30 $0^{\text {th }}, 1982$. He received a MSc in Construction Technology from the Eindhoven University of Technology in The Netherlands. During his study at the Eindhoven University of Technology he developed an interest for innovations which in particular improve the level of industrialization and sustainability of construction projects. Within a sector which has repeatedly blamed for its low level of innovation, he became increasingly fascinated by the question that would eventually lead to this $\mathrm{PhD}$ research: why are innovations so laboriously adopted in construction projects? As a result John joined the Construction Management and Engineering department at the University of Twente to start his $\mathrm{PhD}$ research on innovation adoption in the housing sector. In this project he investigated the adoption of various technological innovations in the housing sector such as industrial housing systems and various modular products (modular renewable energy system, bathroom pod; photovoltaic modular roof).

John is currently employed as a researcher and lecturer in construction management and circular building technology at Zuyd University of Applied Sciences in The Netherlands. Since 2014, he conducts innovation and research projects on the development and adoption of various sustainable - deep-renovation and circular building - technologies. These projects are part of the Smart Urban Redesign research program of Zuyd. Research projects in which John participated include MORE-CONNECT (H2020 project about a modular deep-renovation approach - https://www.more-connect.eu/); SUPERLOCAL (UIA project about circular building - https://www.superlocal.eu/) and DRIVE-0 (H2020 project about applying circular building concept in deep-renovation - $\underline{\text { https: / / www.drive } 0 . e u / \text { ) }}$ 
Academic output

Van Oorschot, J.A.W.H., Durmisevic, E., \& Halman, J.I.M. (2011). Implementation of innovation: The inertia of implementing the open building concept in practice. Proceedings of the international Conference on Management and Innovation for a Sustainable Built Environment, 20 - 23 June 2011, Amsterdam, The Netherlands, ISBN: 9789052693958.

Van Oorschot, J.A.W.H., Hofman, E., \& Halman, J. I. M. (2015). A bibliometric review of the innovation adoption literature. In 75th Annual Meeting of the Academy of Management, 7-11 August 2015, Vancouver, Canada (pp. -). Vancouver, Canada: Academy of Management.

Van Oorschot, J.A.W.H., Hofman, E., \& Halman, J.I.M. (2016). Upscaling large scale deep renovation in the Dutch residential sector: a case study. Energy procedia, 96, 386-403.

Van Oorschot, J.A.W.H., Hofman, E., \& Halman, J.I.M. (2018). A bibliometric review of the innovation adoption literature. Technological Forecasting and Social Change, 134, 1-21.

Van Oorschot, J.A.W.H., Halman, J.I.M., \& Hofman, E. (2019). The continued adoption of housing systems in the Netherlands: A multiple case study. Journal of Construction Engineering, Management \& Inovation, 2(4), 167-190.

Van Oorschot, J.A.W.H., Halman, J.I.M., \& Hofman, E. (2020). Getting innovations adopted in the housing sector. Construction Innovation, 20(2), 285-318.

Van Oorschot, J.AW.H., Halman, J.I.M., \& Hofman, E. (forthcoming). Adoption of modular innovation in the Dutch housing sector. 


Industrialization, digitalization and innovation in housing are essential if one is to address problems such as an increasing demand for affordable housing, labour shortages, the sector's significant environmental impact and fast-changing market needs. This requires substantial innovations. Ideally, these innovations will not only contribute to shorter building times, lower failure costs, a higher build quality, but also result in more sustainable and circular building concepts. However, to benefit from such innovations, they have to be adopted on a large scale. When innovations have been successfully applied in pilots and demonstration projects, they tend to be adopted only on a small scale and fail to diffuse in the market. A more in-depth understanding of the adoption of an innovation within a specific housing project, and subsequently in other housing projects, could have a substantial impact on its adoption rate. The research reported in this thesis aims to enhance current understanding of the adoption of innovations in the housing sector. The emphasis is on the determinants and mechanisms that affect the decisions of construction stakeholders regarding the adoption of innovations in housing projects. The insights that have been developed and described in this thesis may hopefully contribute to increasing the adoption rate of effective innovative solutions and through this, to boost the availability of affordable, sustainable and circular housing in the Netherlands.

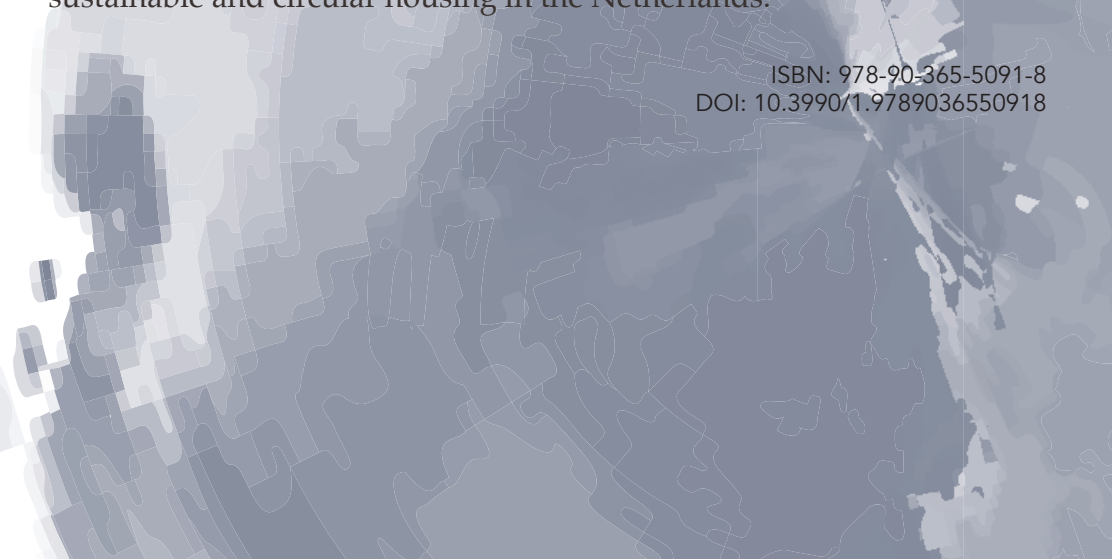

